Flohin Alams 过ilurary.

IN THE CUSTODY OF THE BOSTON PUBLIC LIBRARY.

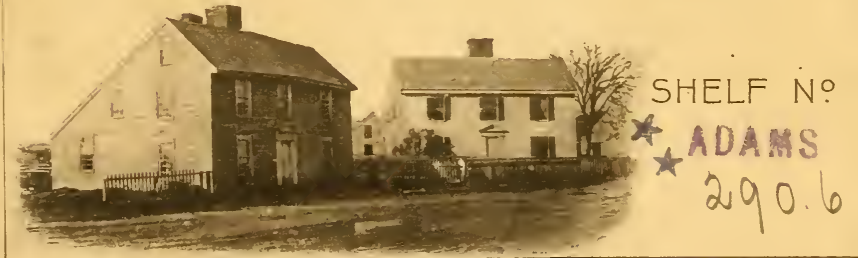






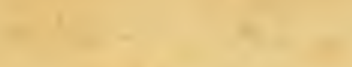

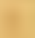

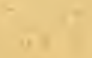

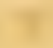




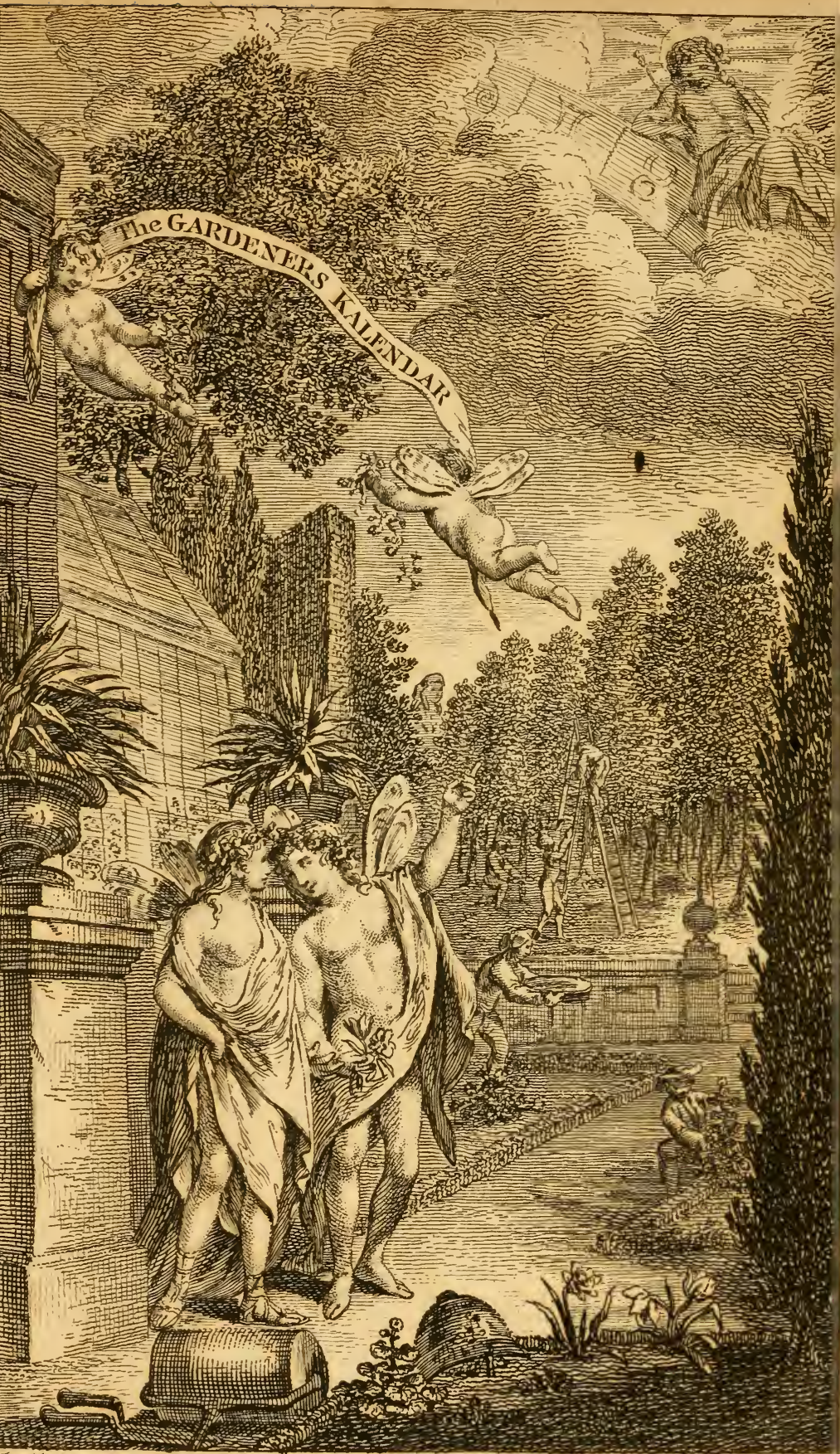

G. Niller deh et Sculp.

Pirntal for. John Rivington and the rest of the Proprietors. 


\section{Gotur Adtams}

T H E

\section{Gardeners Kalendar;}

Directing what Works are neceflasy to be performed

\section{E V E R Y M O N T H}

I N T H E

Kitcben, Fruit, and Pleafure-Gardens,

As alfo in the

Confervatory and Nurfery:

\section{$S H E W I N G$}

1. The particular SEA SONS for PROPAGATING all Sorts of Esculent PIANTS and FRUITs, with the Time when each Sort is proper for the Table.

11. The proper SE A SON S for Tranfplanting all Sorts of Trees, Shrubs, and Plants, with the Time of their Flowering.

By PHILIP MILLER, F.R.S.

Member of the Botanick Academy at F I ORENCE, and Gardener to the Worhipful Company of AFO'THECARIES, at their Botanick Gardes in Chsifea.

The FOURTEENTH EDITION, Witb a LIST of the MEDICINAIPIANTS, which may be gathered for Ufe each M UNT $\mathrm{B}$.

To which is prefixes,

A thort INTRODUCTION to the SCIENCE of BoTANY, illuftrated with Copper Plates.

\section{$L O N D O N$ :}

Printed for the AUTHOR;

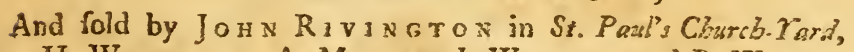
H. Woodfall, A. Millar, J. Whiston and B. White, G. HAWKINS, J. HiNTON, R. BALDWIN, L. HAWES and W. Crarke and R. Collins, W. Johiston, T. LossMAN, T. CASLON, B. LAW, C. RuYNGTON, Zs. STUBRT, J. DODSLEX, and M. RiCHARDSON, 1765. 


$$
\times \text { AOAHS } 290.6
$$




\section{T O}

THOMAS HARRIS, Efq; Malter;

$\left.\begin{array}{l}\text { Mr. John Peck, } \\ \text { Mr. Marmaduke Westwood, }\end{array}\right\}$ Wardens;

And the other MEMBERS

OF THE

COURT of ASSISTANTS

O F T H E

Worhipful Society of Apothecaries OF
$L$
0
$N$
$D$
$O N$

This EDI T ION of the

\section{Gardeners Kalendar,}

Is with the greateft Refpet Infcribed, by

Their moft obedient humble Servant,

Philip Miliero 



\section{T H E}

P R E F A C E.

W. 23. A tions of this Gardeners Kalen-

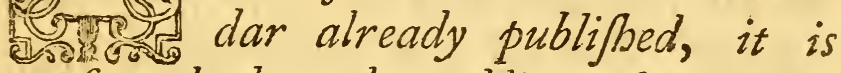
prefunned that the public is fo well acquainted with the performance, as to render it unnecelfary to mention any thing of it bere.

In each of the editions Jubfequent to the forf, there bave been Juch alterations and additions made, as were neceffary to include fuch new plants as bave been an. nually introduced into the Englifh Gardens; and alfo to mention Juch difcoweries sD bave been made in their culture and management, which bave not been few fince the firft publication of this work: therefore if thefe bad been amitted, it 


\section{vi $\quad P R E F A C E$.}

would bave rendered the performance imperfect.

The improvements which have been made in the art of Gardening, witbin fifty years paft, are very great; So that we may without prefumption affirm, that every part of this art is in as great perfection at this time in England, as in any part of Europe. Our markets being better Jupplied with all forts of efculent plants, through the whole year, than thofe of any other country; and thefe in their feveral feafons are afforded at fo cheap rates, that they are become a great part of the food of the poor: to which we may in part at tribute the abatement of thofe violent fcorbutick diforders, which formerly raged fo much in tbis country.

The Kitcben Gardeners (êpecially thofe near London), have experienced, that by treating moft of the efculent vegetables in a lefs tender manner, than was before pracifed, their crops fucceed mush better; and by fowing balf the quansity 


\section{P R E F A C E.}

quantity of feeds on the fame exient of ground, there is a great faving of both jeed and labour, and their piants thrive much better.

The Florifts also bave found out many better metbods of raifing and improving all the forts of flowers, with which the Englif Gardens are now much more plentifully fored than was knowen to their predeceffors; So that many foris which were fome years paft nurfed up with the greateft care, and treated in the moft tender manner, are now commonly planted in the open borders of the PleafureGarden; where they tbrive and are in greater vigour, than when they were treated with much greater nicety, whereby the Flower-Garden is more completely adorned with thefe beauties.

As to the number of exotick trees, Brubs, and plants, which bave been brought into England witbin baif a century paft, it is doubtful if it is not nearly equal to thole before known bere; and a great part of them are become, as it were,

$$
\text { A } 4 \text { deni- }
$$


denizens in England, being fo far naturalized, as to thrive in the open air witbout foelter, and tbereby afford mucb greater pleafure, becaufe they approacb nearer to their natural beauty. And by making trials with many of thofe plants which were formerly nurjed up in greenboufes, and treated with great tender$n e j$, they bave been found to thrive and flower much better when planted in the full ground, and treated with lefs delicacy.

The fe new difcoveries which are annually made in the different parts of Gardening, occafion a necejpity for alterations and additions to be made, from time to time, in the books which are writien upon this fubject; therefore the autbor bopes, that what be bas done of this nature, in the late editions of bis works, will not be interpreted, as if done with a defign to depreciate the former impreffions, or to enhance the fale of the book, both webicb are far from bis intention: but locre be camot belp obferving, that the demand 
mand for this book has been fo great, as to tempt fome of the Bookfellers to endeavour to impole on the publick, by employing their backney foribblers, to purloin from this, and the autbor's larger work, materials for broks on the fame fubject. How well the fe bave been executed, thofe who are the bef acquainted with the fubject, are the moft capable judges. But if we may prefume to guefs at the reception which the fe books bave met with from the publick, by the demand there is for them, we may conclude, that neither of thofe performances will ever come to another edition.

In a work of this nature, which is defigned only to inftruct the practitioner at what times of the year each work is to be performed, it cannot be expected, that the manner of doing thofe works can be bere inferted, as that would fwell the book greatly beyond the limited fize, and render it lefs portable; and as in the Gardeners Dictionary, there are comple inftructions for the raifing and manage- 


\section{P R E F A C E.}

ment of all the forts of trees, frubs, and plants, with robich the Englifh Gardens are at prefent furnibed, not only for the embellifment of the PleafureGarden, but alfo the many kinds of efculent plants which are at prefent cultivated in our Kitchen-Gardens, which were unknown bere in the laft age: fo the curious Reader is defired to turn to that, for directions how to perform the feveral works, in the different branches of Gardening:

The inferting in this work what efculent plants and fruits are in feafon, and alfo the trees, frubs, and flowers, which bloffom in each month, the author believes to be as neceffary as any otber part of the performance; for by this thofe gentlemen who refide in the country but a part of the year, may be inftructed to make choice of Juch fruits, and to cultivate fuch efculent plants in their. Gardens, as will be in feafon at the particular time of the year, when they can enjoy them. The trees, forubs, and flow- 


\section{P R E F A C E.}

ers for adorning their Gardens, may alfo be adapted to the fame time.

In this edition the titles of many of the plants are altered, fo as to correfpond with thofe mentioned in the laft edition of the Gardeners DiEtionary, which was altered to correspond with Linnceus's Syfem.

The directions bere given for the times of Jowing of feeds, the tranjplanting and management of all forts of plants, as alfo when the feveral efculent plants and fruits are in their maturity, as the time of trees, Jrubs, and plants. being in flower, are bere put down for thofe Gardens wbich are fituated near London, and according to the new fyle; fo that in the management of thofe Gardens which are fituated in a more northern latitude, there muft be an allowance made for the difiance they are removed from this metropolis. This muft be underftood in general, for there are fome particular warm foils and fituations, at a great difance from London, 


\section{xii $\quad P$ R E F A C E.}

in which vegetation is almoft as early as the lands in general near London.

It may alfo be neceffary to inform the Reader, that the calculations bere made, are not taken from any particular feafon, but by comparing a diary which the author bas kept many years; and from a medium of Jeveral years obfervation, the whole bas been compiled. For there is frequently the difference of a fortnight or tbree weeks, between one feajon and anotber, in the times of fruit ripening, and alfo in the maiurity of efculent plants. But in many of the winter fruits, there is often much more; for in fome feafons, the pears of a tree wbich grewe to a fouth eaft ajpect, were ripe the middle of $\mathrm{Oc}$ tober, and by the end of the fame month, thofe which were not eaten were become rotten; and in feveral other years, the fruit of the fane tree were not eatable before the end of December. Therefore the Reader is defired to excufe the autbor, when be finds forne forts of autumn or winter fruits, mentioned to be in eating, 
at a different time from that in which they are fome years in their maturity, becaufe fuch alterations frequently bappen in the feafons, as will occafion the difference before-mentioned in the time of ripening of feveral fruits.

There are alfo the fame kinds of work, directed to be performed in different montiss, which to thofe who are unexperienced in the praetical parts of Gardening, may appear to be abjurd; but thofe who are better acquainted with the fubjects, know, that in different feafons and fituations, the fame work may be performed to advantage, three weeks or a mont bearlier or later; fo that the practitioner muft be directed berein by bis own judgment and obfervation, as it is impolfible to prefcribe rules for the variety of feafons and fituations, without repeating thefe necelfary works in different months; therefore the mof fkilful Gardeners will allow of the fe frequent repetitions, knowing it to be very neceffary to put crops into the groind, when thofe before 


\section{xiv $\quad \mathrm{P} R \mathrm{EF}$ A C E.}

before fown or planted may bave failed, otberwife a whole feafon may be loft. And it is boped thofe who are lefs acquainted with the practice, will not confure what they do not underftand.

To this edition of the Gardeners $\mathrm{Ka}$ lendar, the autbor was advifed to Jubjoin a fort Introduction to the Science of Botany; in which the definitions and terms of art which are ufed in the prefent favourite Jyftem of Doctor Limneus, Bould be explained; for the benefit of practical Gardeners; efpecially fince the having fome fill in the knoweledge of plants, is now become anecelfary qualification for thofe who bave a defire to advance themfelves in their profeffion; therefore the author was foon prevailed on to undertake it, and accordingly bad the plates engraven, and the wibole prepared for the prefs, before the tranflation of Linneus's Pbilofopbia Botanica, publißhed by Mr. Lee, made its appearance. When that was made publick, the author of the Gardeners Kalender bad fome doubts 


\section{P R E F A C E.}

doubts about the publication of bis; but upon fartber confideration, be was determined to add it to the Kalendar, as the fubject is treated differently, and only the more effential parts of the Linnean fyftem are bere explained, the whole being comprifed in fo Jmall a compass, as to enbance the price of the book but little: and for the benefit of thofe, who are already polfelfed of either of the former editions of the Gardners Kalendar, this fmall tract is prinied Separately, and may be purchajed by thofe who are defirous to bave it.

As the autbor bas been careful in the revifing the whole work, and inferting of the neceffary additions and alterations made in this impreffion, be bopes it will meet with the like favourable reception from the publick, as the former editions bave done, and for which be thinks be cannot beiter tefify bis gratitude to the. publick, than by endeawouring to promote, to the utmoft of his abilities, the ujeful art of Gardening. 



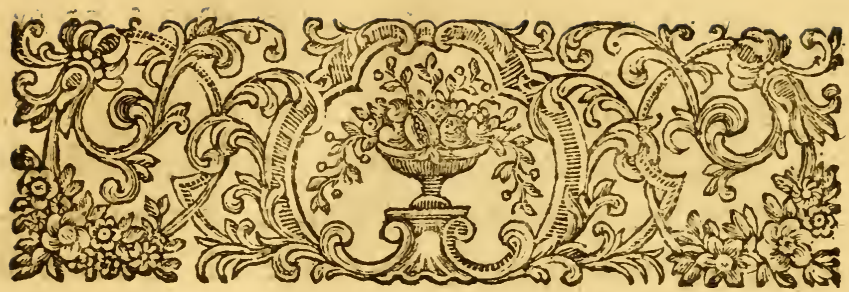

A S H O R T

\section{INTRODUCTION TO THE}

SCIENCE Of BOTANY.

L L the fciences have each their 1. 1. ABs proper language: but Botany alone 5. Ev to has almoft as many different lan5.2) 19

guages as there are different authors, each ufing names and particular phrafes, to reprefent the fame plants; and fometimes the fame denomination is applied by different authors to different plants; but although the Nomenclature of Botany has in all times been varied, yet it never was fo much altered as of late years. New views have occafioned new obfervations, which have enabled the modern Botanifts to realify the denominations of the antients. 
A denomination is fo much more perfect, as it contains fewer arbitrary things, and has lefs relation to foreign. This is a kind of definition, which muft be rendered as exact as poffible, ufing the vifible attributes and qualities of the plant itfelf, making an abftraction of the affinity it has to other plants of the fame genus, or of different genera.

The modern Botanifts have an advantage over the antients in following this rule; they name the plants from the parts which they contain; whereas the others have generally given them by their outward appearance, or fuppofed virtues; the moderns in each of their phrafes, have regard to the effential parts of the plant they exprefs: that in a word is the moit particular character, which can be known by the firft infpection, avoiding the long denominations and terms which are fuperfluous, and only burden the memory to no purpore, they have banihed the names of the countries where the plants grow, their virtues, and properties, Ec. from the titles.

When there is but one known fpecies of a genus, it is not neceffary to add a fpecific denomination to its generical name, becaufe there is no other fpecies to dilinguifh it from. And it were to be wimed, that each plant had but 


\section{the Science of Botany.}

one effential character to diftinguih it from all the other fpecies of the genus: in which cafe, each denomination would be comprifed in two or three words. But as it often happens, that one fpecies has many different characters common to one or other fpecies of the fame genus, they are then obliged to add a longer denomination to it. However, all other things being equal, the hortert phrafes are always beft. In confequence of this, Dr. Linnaus, the celebrated Profeffor of Botany at Upfal in Sweden, has propofed fimple and proper terms, not only to exprefs all the different parts of plants, but alfo the principal qualities, forms, figures, fituations, directions, and manners of exifting of each of thefe parts. $\mathrm{He}$ is not fatisfied to join the definitions and explications to each of thefe terms, to fix and determine their true meaning: but he has alfo added figures, to fuch as were neceffary to give a more juft and complete idea of them. Thefe principals have been almolt univerfally adopted, by thofe who have wrote after him. This rule he will not permit to be departed from, and his manner of expreffion is become the living language of Botany.

The fexual method of claffing plants, eftablined by Dr. Linnaus, is much prefer- 
able to all the fyftems of Botany which have yet appeared. 1. Becaufe of all thofe which have been propofed, there is not one of them which approaches fo near to a natural method as this, mort of the claffes being very natural. 2. It is founded upon the parts of the plants, which are the moft conftant, and leaft fubject to variation, the ftamina and pointals, which are the true organs of generation.

Thefe are fimple and eafy to retain in memory. The claffes are eftablifhed upon the ftamina or male organs; the orders or fubdivifions of the claffes upon the pointals or female organs; and the genera upon all the parts of the fructification. All thefe parts being confidered according to their number, their figure, their proportion, and their fituation, the fpecifick differences are taken from the habit or external appearances of the plants. Thofe who will take the trouble of examining this method, and comparing it with any of the former, will be much better acquainted with its excellence than words can explain it. The author does not pretend to fay it is perfect; the only natural method, if there is one, fhould have an advantage of this, but in default of the laft, he endeavours to follow that which approaches neareft to it.

Dr. 


\section{the Science of Botany.}

Dr. Linnaus has taken the moft effential parts of the plants, which are thofe of the fructification, to eftablin the characters of the genera, in a more fubftantial manner, than all the authors who have preceded him. The exact defcriptions which he has given of all thefe parts, and the hort natural terms which he has ufed, together with the obfervations which he has added to thofe of his genera, which carry any effential 'characier, or which are liable to exception in any of the fpecies, are owing to the labour of this worthy botanift. It is certain, that thefe defcriptions will have this advantage, that they can be applied to any method which may be hereafter invented, for the eftablining of new genera, when the old ones are infuficicient, by the junction of thofe whofe identity have efcaped the firft methodifts, by the difmembering of fome of them, which were overcharged with fpecies, (which fatigue and embarrafs the learner,) in Mort, by clearing of fome other whofe characters are equivocal or obfcure. Dr. Linneus has found a way of sanging the fpecies under their true genera, and of feparating thofe which do not properly belong to them.

The diftinguihing varieties from real fpecies, is a part of the fcience of botany not well underftood; for as variety of foils, fituation, and

culture, 
culture, greatly alter the appearance of plants, fo there are too many, who from a fondnefs of thewing their great nicety in diftinguilhing, are apt to make fpecies of feveral plants, which are only accidental variations; while others, on the contrary, are as ready to fuppofe many plants which agree in fome particular characters, are only accidental variations; and it muft be confeffed, that the learned author whofe fyftem we here adopt, is of this number; for in all his books where he has enumerated the fpecies of plants, he has joined by way of fynonim many plants as varieties of the fpecies, which are always conftant in their effential characters, when propagated by feeds, be the foil or fituation ever fo different : but this may be readily excufed; for as he has not had experience enough in the culture of plants, to know how far, that with the difference of foils and fituations will alter the appearances of plants, fo it cannot be expected he fhould be perfect in an article, which requires many years trial and obfervation to determine. Nor has this learned author lived long enough in a country, where he might have opportunities to fee and examine the plants growing; fo has been obliged to form great part of his fyftem from dried famples of the plants, which tho' 


\section{the Science of Botany.}

they may have been well preferved, yet fome of thofe effential parts of their flowers and fiuits from whence he has taken their characters, may have been wanting; or at leaft fo much impaired, as to render it impoffible for any one, abfolutely to determine their claffes or genera: therefore future obfervations on the plants made by perfons of $\mathrm{A}$ ill, who have opportunities of examining them when growing and in a perfect ftate, it is hoped may reduce this method nearer to a natural one.

The following circumftances are excluded by Dr. Linnaus, from having any thare in diftinguihing the fpecies from varieties, viz. fex, magnitude, time of flowering, colour, fcent, tafe, virtues and ufes, duration, multitude, pubefcens, leaves and monftrous flowers. Molt of which it muft be confeffed, thould not be allowed as diftinguithing characters to fpecies; but there are fome which muft be admitted, where other marks are wanting to diftinguifh two fpecies which have great affinity, provided the characters fo ufed are permanent: and thefe we find have been frequently ufed by $\mathrm{Dr}$. Linnceus himfelf in his later works, with great propriety, and it may be prefumed as he becomes more knowing, he will adopt many more. For inftance in the Crocus, the Doctor has fuppofed that the vernal forts are 
only varieties of the true Saffron, which always flowers in autumn; but whoever will examine flowers of each, will find the ftigma of the latter divided into three parts to the bottom (and this is the part in ufe), whereas the figma of the vernal Crocus is globular and almoft intire. There are alfo many other plants, which have efcaped the notice of the author, and by him fuppofed to be only varieties, which are in reality diftinet fpecies.

According to modern Botanifts, plants are fuppofed to confint of the fix following parts, the Root, Radix, the Trunk, Truncus the Sup: port, Fulcra, the Leaves, Folia, the Flowers, Flores, and the Fruit, Fructus.

The Root, Radix,

Is that part of a plant which is faftened to the ground, or to fome other body, from whence it draws its nourihment.

Roots are divided into three forts, viz. fibrous, bulbous, and tuberous.

A fibrous root is compofed of many fmall roots, which divide at the ftalk or trunk, fee fig. I. plate I. Thefe are fometimes perpendicular, and are called tap roots, as at $a, f$, or horizontal, which are called fpreading roots, as at $b$. Flefhy, or Carnofe, as the Carrot and Parjnep, fee fig. 2. Hairy, Filomentofa, which appear? 

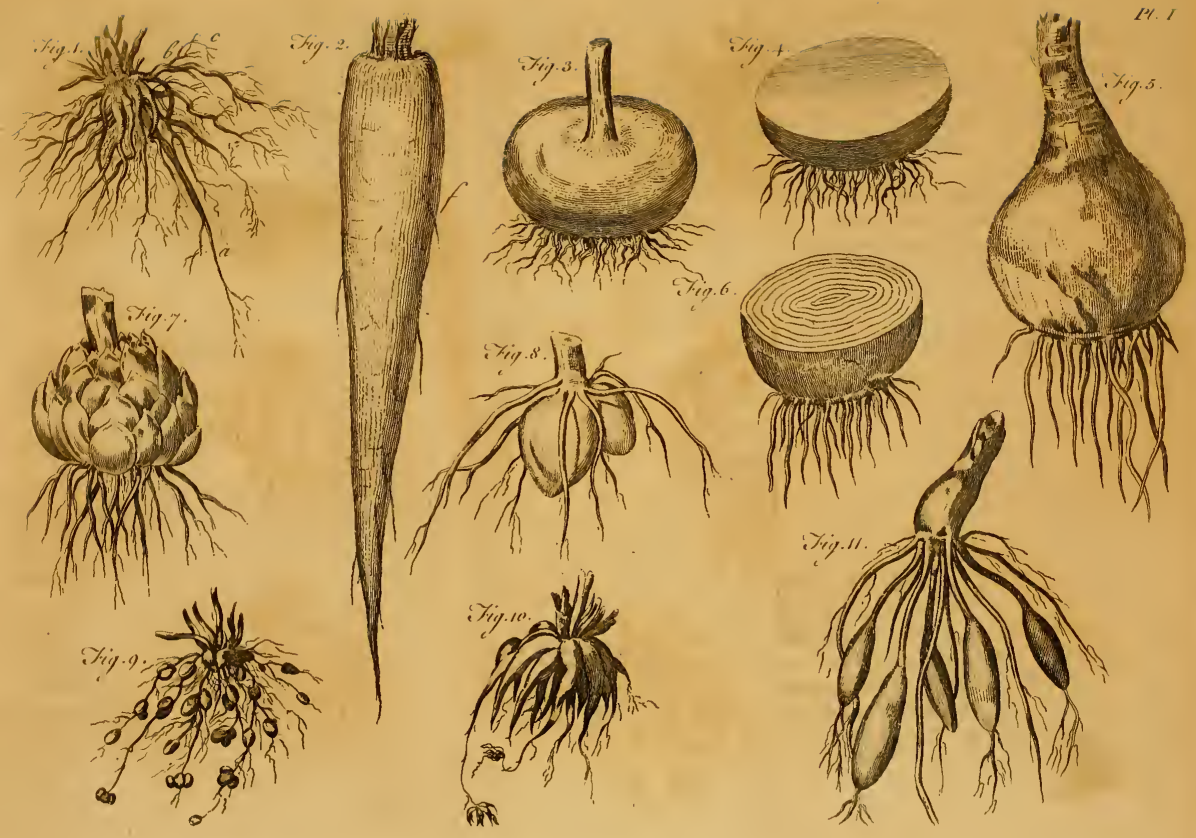

appear like flende: threads or bairs, like the roots of $\mathrm{Grafs}$, as at $c$, fig. I. fingle at fig. 2. and branching at fig. I.

Bulbous roots are of the five following forts, I. Solid, Solida, as fig. 3. thefe are of a thick flefhy folid fubftance, as the Turnep, reprefented at fig. 4. which is cut horizontally through the middle. 2. Coated, Tunicata, as the Onion, fee fig. 5. which are compofed of many lamina, or coats, clofely furrounding each other, as is reprefented fig. 6 . where it is cut through the middle. 3. Scaled, Squamoja, as the Lily, fee fig. 7. thefe are compofed of many flefhy fcales lying over each other. 4 . Double, Duplicata, as in fome Species of Orchis, fee fig. 8. where there are two folid bulbs joined; thefe are alfo called Tefticulated roots. 4. Cluftered, Aggregata, as the White Saxifrage, fee fig. 9. thefe are alfo called Granulous roots, having fome appearance of grain.

A tuberous root is one that is compofed of many flethy tubers, as the Garden Ranunculus, which fwell more than the ftalk, fee fig. 10. when thefe adhere clofely to the ftalk, they are termed feffilis, i. e. fiting clofe; or if they are fufpended by threads, as the Peony, and Hemoracalis, they are called pendulous, fee fig. I I. thefe are of different figures. 


\section{The Trunk, Truncus,}

Is that part of a plant which rifes immediately from the root, and fuftains the branches; this denomination, is therefore only given to trees; and that of ftalk to plants.

Stalks are divided into fimple or compound.

A Simple Stalk, Caulis Simplex, is one which arifes fingle from the root, and continues fo without interruption to the top. This is alfo called an intire ftalk, caulis integer. When the ftalk has no leaves or branches, it is called a naked ftalk, caulis nudis. When it is garninhed with leaves, caulis foliatus, a leafy ftalk. When it it is upright, caule rectus. Or if it is oblique to the root, caule obliquus. When it twines round a fupport, caule volubilis. If it is pliant, caule flexuofus. When it reclines to the ground, caule reclinatus. If it lies upon the ground, caule procumbens. When it puts roots out of the joints which faften to the ground, caule repens, a creeping ftalk. When it puts out roots the whole length of the ftalks, farmentofus. If the falks live feveral years, they are termed, perennis, abiding ftalks, if but one year, annuus, annual. When they are lignous or woody, fruticofus, Mhrubby, or fuffruticofus, under thrubs. If they are cylindrical, teres, 


\section{the Science of Botany.}

or taper. When they have two angles, anceps; if three angles trigonus; if many angles, polygonus. When a ftalk is ftreeked, friatus. If furrowed, canaculatus, channelled. When it is fmooth, glaber. If it is hairy, villofus. If rough, fcaber. And if the hairs are prickly, bijpidus.

\section{A branching Stalk, Caulis ramofus,}

Is one that puts out lateral branches as it afcends. If the branches are irregular and thinly placed, it is called a diffufed ftalk, diffufus. If they are large, bracbiatus, or limbed. When there are a great number of branches, ramofifimus, very branching. If they have fupports, fulcratus. When they are prolifick, proliferous.

A compound Stalk, Caulis compofitus, is one that foon divides into branches; when it is forked, it is called dicbotomus; if it has two ranges of branches, difticbus; or when thefe are again divided/ubdivifus. A ftraw, culmus, is a fiftulous ftalk garnifhed with leaves, and is generally terminated by a fpike or panicle, as in graffes or corn. If this is intire, integer; or branched, ramofus; if uniform, aqualis; if jointed, articulatus; or fcaley, feruamofus; if without leaves, nudus; or when garnihed with leaves, foliatus. 
The fupports, fulcra, are certain parts of a plant, which ferve to fuftain or defend the others. Thefe are of the ten following forts. The fipula. The leaf which fupports the flowers brictecs. The tendril or clafper cirrbus, or capreolus. The fpine fpina. The thorn aculeus. The foottalk of the leaf petiolus. The foottalk of the flower or fruit pedunculus. The ftalk frapus. The gland glanchula. The fcale Squama.

The footfalk which fuftains the flower or fruit is called pedunculus, If this fuftains but one flower or fruit, unicam. If two, geminam; if feveral, plurimam; and when it fupports a great number, aumerofam. When thefe arife from the root, radicalem; from the ftalk, caulinom; from the wings of the ftalk, alarem; or from the extremity, terminatricem, or terminalem. If they are fingle, folitariam; or thinly placed, Jparfam; if in groups, conglobatam; in clufters, conglomeratam; if in panicles, paniculatam; or in roundifh bunches, corymbofom; if in clofe bunches, or bundles, falciculaiam. When they are in whorles round the ftalks, verticillatam; or in fpikes, spicatam. If in long bunches like grapes, racemofam; or in form of an umbrella, umbellatam; if in form of a head, capitatom. 
The ftalk fcapus is fo called, when it rifes fingle from the root without branches, and immediately fupports the flowers and fructification, as the Arum.

The footftalk of the leaf petiolus, is that which fuftains the leaf as, the pedunculus furtains the flower and fruit, and is fometimes called the tail of the leaf.

The tendril, cirrbus or capreolus, is a clafper, by which a plant faftens itfelf to any other body for fupport, as the Vine, Briony, \&cc.

The bractea, or floral leaf, is of a different form and colour from the other leaves, and is always fituated near the flower, and never appears but with it; fo may be termed a foral leaf.

The ftipula is a fale which forms the future bud, and is fituated at the infertions of the leaf.

The thorn, acculeus, is a tharp brittle point, which is fo flightly faftened to the plant, as to be taken off without tearing the other parts.

The fpine, Jpina, is fo frimly fartened to the plant, that it cannot be taken off without tearing it.

The gland, glandula, is a kind of teat which ferves for the fecretion of the humours. 
The fcale, fquama, is generally found in katkins, where they ferve as a cover to the ftamina and apices of the male flowers; and in fome flowers at the bottom of the flower-cup, or under the flowers themfelves, in fome plants.

\section{Of LEA ves, Folia.}

I hall not here mention all the varieties of leaves, which are taken notice of by fome of the late writers in Botany, but Rall only include their principal or moft effential differences; and fhall not take the terms from a fingle difference, but from fuch as are common to many; for the inferting too great number of terms will burden the memory too much, which will embarrafs the learner in the application of them; and if thofe here mentioned are not fufficient to difinguih every variety, we thould endeavour to keep a juft medium between the old and new terms, avoiding the two extremes.

When two genera of leaves are combined to form one fpecies, or the fpecies is compofed of two genera, which become the parts of the fpecies, thefe genera being once eftabliphed, it will not be difficult to form the fpecies, io as to require no other definition, provided the genera 
genera are well defined, and do not burden the memory; as for example,
Cordato-ovatum.
Ovato-cordatum.
Cordato-oblongum.
Oblongo-cordatum.
Cordato-lanceolatum.
Cordato-Sagittatum.
Cordato-baftatum.
Lanceolato-cordatum.
Sagittato-cordatum.
Haftato-cordatum.

There muft be great care taken in placing the genera either firft or laft, in the formation of the fpecies, for this is not indifferent; the laft denotes the form in which the leaf refults, and the firft in fome meafure corrects it, by adding a fort of exception to it; fo that by changing their place, it will alter the definition of the leaf. As for example, Cordatoovatum, by this is to be underftood a leaf more approaching to an oval. But when it is Ovatocordatum, the leaf is fuppofed to be more of a heart-Thape. But this will be better conceived by their figures hereafter referred to.

Leaves are divided into the three following claffes.

1. Single leaves.

2. Compound leaves.

3. Determinate leaves. 
The Ift clafs of fingle leaves. Plate II.

Thofe leaves are called fingle, fimplicio, -whofe foot?talks fupport but one.

There are feven forts of fingle leaves, where we confider a leaf according to its circumferences, finus, its borders, its furface, its fum= mit, and its fubftance.

The circumference (circumecriptio) of a leaf depends upon its border having no finus or angle; therefore we fhould comprehend in this title all thofe leaves whofe figures are in form of a ring differently compreffed, if they have no finus or angles.

I. We call a leaf orbicular or round (orbiculum) whofe length and breadih are equal, and whofe borders are equally diftant from the center, as the Soldanella, fee fig. I. plate II.

2. A roundin leaf (Jubrotundum) is one whofe breadth is greater than the length, fee fig. 2. but this term is often ufed in a more extenfive fenfe.

3. An oval leaf (ovatumi) is in form of an egg, and is longer than it is broad; and when the bafe or lower part forms a fegment of a circle, but the upper part draws nearer to a pnint, fee fig. 3 .

An obverfe oval leaf (obverfe-ovatum) is one in form of an egg reverfed, the fame as fig. 3. 

fig. 3. when the part which is faftened to the footftalk is narrower than the top.

4. An oval or elliptick leaf, is one which is longer than it is broad, and whofe upper and lower parts have the fame fegment of a circle, fee fig. 4 .

An oblong leaf (oblengum) is one whofe length is more than twice the breadth, and the two points are narrower than the fegment. of a circle, fee fig. 5 .

A wedge-flaped leaf (cuneiforme) is one that is thaped like a wedge; the length is much greater than the breadth, and is nar-" rowed from the top to the bafe, fee fig. 45 .

The angles of a leaf (anguli) are the prominent parts which project from the border of an entire leaf.

An angle is different from a finus, as it is the projecting part of a leaf, fee fig. 20. $e, a, e$, whereas the finus is the part which is diminimed, fee fig. $20, a, c, b$, fo the angle exifts in the leaf, and the finus is without the leaf. We muft not confound the fides with the angle, as is frequently done. The angle in a leaf is confidered horizontally, fig. $20 . a, b, c$, and the fide of a leaf in a perpendicular view, see fig. 58. $a, b, s$. 
A fpear-tharped leaf (lanceolatum) is thaped like the point of a fpear; it is oblong, and gradually narrowed from the middle to both ends, where it ends in points, as in the narrowleaved Plantain, \&xc. fee fig. 6.

A linear or narrow leaf (lineare) is that. which commonly is narrowed toward the two ends, but the fides are parallel its whole length, as Rofemary, \&cc. fee fig. 7 .

An awl-haped leaf (fubulatum) is fomewhat like the former on its upper furface, but the under part is thicker in the middle, growing narrower to a point at the top, like the point of an awl, as in the Mefembryantbemum fcabrum, Lin. fee fig. 8.

A triangular leaf (triangulare) is one with three rectangular fides, and three angles, the two lower being even with the bafe, as in the Mefembryantbemum bellidiflorum, fee fig. I 2 .

A deltoide leaf (deltoides) is one with four angles, the two at the top being at a greater diftance from the center. than thofe of the fides, as in the Sea Orach, fee fig. $5^{8}$.

A quinqueangular or five cornered leaf (quinqueangulare) is one whofe fides are frait to the middle and are not broken, as in that of Lavateria Olbia, fee fig. 20. $a, b$, this fometimes happens. 


\section{the Science of Botany.}

After thefe differences are once eftablined, it will be eafy to figure any other varietics which may arife, from the number of angles, which rarely happen.

A round leaf (rotundum) is one that has no angles or indentures, fo is different from the preceding, efpecially the feventh and twelfth.

A finus divides the difk of the leaf into many parts at the bafe, as in fig. 14 , and 18 . at the top, as in fig. 2I, 22. at the fides, as in, 23,25 . the whole length, as in fig. 26 .

A kidney-rhaped leaf (reniforme) is that, which is Thaped like a kidney, it is almoft orbicular, but indented at the bafe without angles, as the common Scurvy-grafs, fee fig. 9 .

A heart-haped leaf (cordatum) is Maped fomewhat like an egg, but is indented at the bafe without angles, as the Water Figroort, fee fig. IO.

A moon-Thaped leaf (lunatum) is fomewhat like an half orbicular leaf, but is deeply inden:ed into two curve angles at the bafe, like a half moon, or fome forts of Paffifora, Lin. fee fig. II.

An arrow-pointed leaf (Jagitatum) is a triangular !leaf indented at the bafe-like the point of an arrow, as the fmall wild Convolsulus, fee fig. 13. 
An heart arrow-pointed leaf (Cordato-baftatum) is like the former, but the borders are convex, as in the Arum, fee fig. I4.

A pike or javelin-hhaped leaf (bafiatum) is a triangular leaf whofe fides and bafe are indented, and the angles are expanded like the point of an halberd, as the Sheeps Sorrel, fee fig. I 5 .

A bifid leaf (bifidum) is a leaf divided at the top in two parts, whofe inferior borders within the divifion are ftrait, as the Baubinia, fee fig. I6.

There are fome leaves which are divided into three parts (trifidum) as the Rue-lear'd Wbitlow-grafs; others into four (quadrifidum) as the Leffer Mallow; fome into five (quinquefidum) as the Altbaa Vulgaris; and others into many (multifidum) as the five-leav'd LadiesMantle. From the number of thefe divifions, they are eafily known.

A trilobate or three-lobed leaf (trilobum) is one that is divided into three lobes to the middle, which are feparated from each other, and their borders rounded, as the Trefoil and Wood Sorrel, fee fig. I7.

When the leaves are divided into two lobes (bilobum) or four (quadrilobum) or five (quinquelobum), as in fome of the Mallows; fo from the 


\section{the Science of Botany.}

the number of their lobes they may be eafily defined.

A palmated-leaf (palmatum) is in form of a hand opened; it is divided into feveral parts from the top to the middle, or almoft to the bafe, as Hemp, fee fig. 22.

A wing-pointed leaf (pinnatifidum) is' one which is cut into feveral lateral finufes, feparated their whole length like the feathers of a wing, as in Hartforn Plantain, \&xc. fee fig. 23.

A jagged leaf (laciniatum) is one that is cut into many finufes, to the midrib, and the lobes are alfo cut undeterminately on their borders, as in fome of the Centaurea, fee fig. 24.

A finuated leaf (finuatum) is one that is cut on the borders into finufes the whole length, which are feparated by lobes which are but flightly intended, as the Acontbus, fee fig. 25.

An indented finuated leaf (finuato-dentatum) is the fame with the former, but the lateral lobes are narrower, as Cicory, fee fig. 26.

A quinquepartite leaf (quinquepartitum) is one that is divided into five parts to the bafe, as the Black Hellebore, fee fig. 28.

In changing the number of parts into which the leaf is divided, we may denote their 
fignification, as in two (bipartitum) in three (tripartitum) in four (quadripartitum) and if into many (multipartitum).

An entire leaf (integrum) is one which has no finus on its border, and an undivided leaf (indivijum) is the fame, but integrum muft te diftinguimed from integerrimum; the firft denotes a leaf which has no finus in its difk, and the fecond has none on its border.

The margin or border of a leaf (margo) denotes the variety there is feen on the edges of leaves; but thefe have no relation to their difik, nor are the extremities at the top included in this diftinction.

An indented leaf (dentatum) is one that has its borders end with horizontal points of the fame confiftence with the leaves, but are feparate and diftinct from each other, as the common Horebound.

A fawed leaf (Serratum) is one whofe borders are Marply indented like the teeth of a law, lying one over the other like tiles, and generally point toward the top, as the Annual Nettle, fee fig. 31 . When thefe indentures point toward the bafe, it is termed retrorfum ferratum, i. e. fawed backward.

A double fawed leaf (duplicato ferratum) is one whofe borders are garnithed with two 


\section{the Science of Botany.}

forts of teeth, one fmall and the other large, fee fig. 32 . the lefs upon the greater, as in the Wild Sage.

A crenated or notched leaf (crenatum) is one whofe borders are cut into angles or indentures, which are contiguous and turn inward, without any bend either to the top or the bafe, as the Common Betony, fee fig. $3^{8}$. When the notches are pointed, it is termed (acute crenatum), fee fig. 35. and when they are rounded (obtufe crenatum), fee fig. 36 . and a double crenated leaf, is one that has fmall crenatures upon the larger, fee fig. 33 .

A repanded leaf (repandedum) is one whofe border is indented the whole length, and the lobes are each a fegment of a circle, with obtufe finufes between them, fee fig. 46 .

A cartilaginous or griftly leaf (cartilagincum) is one whofe border is diftinguifned from the other part of the leaf by a cartilage or membranous flehy fubftance, fee fig. 34 .

A ciliated leaf (ciliatum) is one whofe border is fet round with fmall parallel hairs, like thofe of the eye-lid, fee fig. 50.

A lacerated or torn leaf (lacerum) is one whofe border is compofed of torn fegments of different fizes and figures, as in the Sea Cabbage, fee fig. 24 . 
A curled leaf (crifpum) is one whofe border is plaited and fringed like a furbelow, as the curl'd or fring'd-leav'dMallow, fee fig. 39.

A knawed leaf (erofum) is one whofe finus and difk apea: as if they were eaten on their borders, as the Pyrenian Ciary, fee fig. 21.

An entire leaf (integerrimum) is one whofe border is quite entire without any tsind of indenture, fee fig. 42 .

The fuperficies of a leaf denotes its furface above and below.

A downy leaf (tomentofum) is one whofe furface is covered with hairs fo fmall, as not to be diftinguithed by the naked eye, like cotton cloth, as the Muillein, fee fig. 48 .

A velvet leaf (pilofum) is one whofe furface is garnifhed with hairs which are difcernible, as in the Guncus, fee fig. 47 .

A hairy leaf (birfutum) is very near a-kin to the former, but the hairs are longer, as in the bairy Hawkweed.

A flinging leaf (bijpidum) is one whofe furface is covered with rough brittle hairs, which fting the flerh when handled, and are eafily broken, as in the Nettle, fee fig. 49 .

A rough leaf (fcabrum) is one whofe difk is covered with fmall inequalities, or tubercles. 


\section{the Science of Botany.}

A brifty leaf (aculeatum) is one whofe fur face has many cartilaginous briffles which eafily feparate from the leaf, as in forme Rofes.

A prickly leaf (Jpinofum) has its difk or border armed with cartilaginous thorns which adhere clofely to the leaf, and cannot be feparated without injury to the leaf, as the Blackberry.

A warted leaf (papillofum) is one whofe furface is garnifhed with fmall protuberances or veficles, as in the Mefenzbryantbemum Crifallinum, fee fig. 54.

A polifhed leaf (nitidum) is one whofe fur. face is fmooth, and thining as if polifhed, as the Chryfophyllum.

A plaited leaf (plicatum) is one that is plaited from the bafe by a fort of nerve which extends to the border, one being raifed, and another depreffed alternately, fo as that the difk appears in angles, as the White $\mathrm{Hel}$ lebore, fee fig. 37 .

A waved leaf (undulatum) is that whofe outer part of the difk becomes extended beyond a circle of the fame diameter, in fuch a manner that the borders rife and fall like waves, as in the fringed Hartfongue, fee fig. 46 . 
A wrinkled leaf (rugofum) is one that has deep veins, leaving between them fpaces, where the fubftance of the difk rifes like flefh interpoling, as the Primrole, fee fig. $5 \mathrm{I}$.

A veined leaf (venofum) is one that has branching veins or veffels running thro' it, or appears to have a great number of orifices of veins joined, as the Card Beet, fee fig. 52 .

A nervofe leaf (nervofum) is one that has fingle veins, extending parallel from the bafe to the top without branching, as the Scorzonera, fee fig. 53 .

A naked leaf (nudum) is one that has no marks or veins, fo is oppofite to the former.

The point or top of a leaf (apex) reprefents the diverfities there are in the upper extremity.

A truncated leaf (truncatum) is one whore top is terminated by a tranfverfe line.

A blunt leaf (retufum) is one whore top is terminated by a blunt line.

A bitten leaf (premorfum) is one whofe top is divided by an open pointed finus, as the Maple Tree, fee fig. 18 .

A hollowed leaf (emarginatum) is one that is flopewife indented at the top; when it is terminated by blunt fummits, it is termed (obfuffe-emarginatum) fee fig. 45 . and when it is 


\section{the Science of Botany.}

terminated by pointed fummits, as the Tulip Tree (acute-emarginatum).

An obtufe leaf (obtufum) is one that is terminated by a fegment of a circle, fee fig. 40 .

A pointed leaf (acutum) is terminated by a harp point, fee fig. $4 \mathrm{I}$.

An awl-pointed leaf (acuminatum) is one whofe fum.nit is terminated like the point of an awl, fee fig. 42 .

A blunt-pointed leaf (obtufum cum acumine) is one whofe top is blunt and terminated by a Tharp point, fee fig. 43 .

The fides of a leaf (latera) is perceived when all the parts are confidered in a perpendicular fituation.

A taper leaf (teres) is one that is of a cylindrical form, or thaped like a pillar except the fummit, as in Antbericum frutefcens, fee fig. 62.

A piped leaf (tubulofum) is one that is hollow, but cannot be perceived unlefs it is cut tranfverfely, as the Onion.

A flemy leaf (carnofum) is one that is full of pulp, or flehy fubftance between the membranes, which form the upper and lower fur face, as the Aloe vulgaris. 
A membranaceous leaf (membranaceum) is one that the membranes do not inclofe any pulp.

A deprefled leaf (depreffum) is one that appears as if it was preffed on the fide which regards the ftalk.

A compreffed leaf (comprefum) is one that is impreffed on the two oppofite fides which do not regard the ftalk.

A flat or plain leaf (planum) is when both the furfaces are level and parallel every where.

A convex leaf (convexum) is a depreffed leaf raifed in the middle above the fides.

A concave leaf (concavum) is one that is hallowed in the middle.

A channelled leaf (conaliculatum) is one that is channelled or guttered the whole length, fee fig. $6 \mathrm{r}$.

A fword-haped leaf (eniforme) is one that is comprefled, and edged like a fword on both fides, with a convex middle the whole length, as the Flag-leav'd Iris, \&c.

A fabre-Maped leaf (acinaciforme) is a compreffed flefhy leaf like the point of a fpear, with one edge convex and narrow, the other broader and raifed, and the inner blunt and ftraiter, as in the Mejembryantbemum acinaciformi, Lin. lee fig. $5^{6}$. 

Nev

$\sqrt{2}\left\{\begin{array}{l}2 \\ 2\end{array}\right\}$

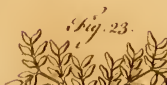

gron

辽得

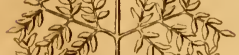

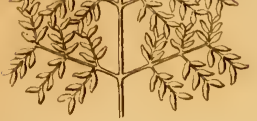

miin 20.

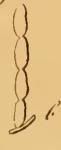

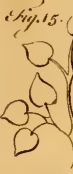

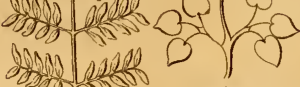
2xos 1350

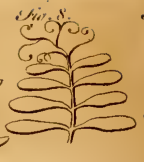

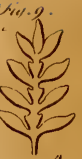

1
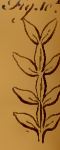

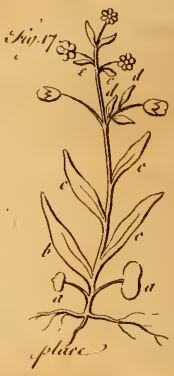

Niin. 4 -

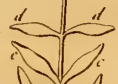

$1 \sqrt{1}$

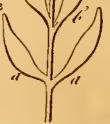

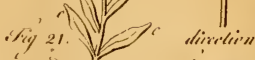

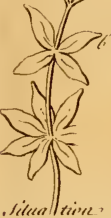

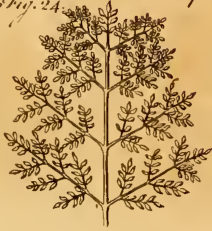

Xiij. 19

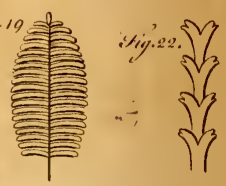




\section{the Science of Botany.}

An hatchet-ihaped leaf (dolabriforme) is a compreffed fuborbicular leaf like a plainer; it is blunt, projecting or fwelling outwardly with a Tharp edge, and alinoft cylindrical toward the lower part, as in the Mefembryantbemum dolabriformi, fee fig. 57 .

A tongue-naped leaf (linguiforme) is a depreffed linear fleiny leaf, a little convex on the upper fide, and has generally cartilaginous borders, as the Tongue-flaped Aloe, fee fig. $55^{\circ}$

A three fided leaf (triquptrum) is one that has three fat iongitudinal fides, but is generally awl-pointed.

A three cornered leaf (trigonum) is like the former, but the facts are channelled and the projections are membranous.

Of Compound Leaves, Plate III.

Compound leaves are divided into fimple and decompound.

A compound leaf is compofed of feveral fmall leaves united together upon the fame common footfalk, which is but one compound leaf.

A leaf is called (folium) but when it is compofed of many fmall leaves, thefe fmall leaves are called (foliolum) which form a compound leaf. 
A compound leaf when properly underftood, is one which is produced from a fingle compofition.

A fingered or handed leaf (digitatum) is one compofed of feveral fmall leaves fitting on the top of a common footftalk, but in a ftrict fenfe it thould be compofed of more than four fmall leaves, as the Agnus Caftus, or Chafte Iree, fee fig. I.

A trifoliate leaf (ternatum) is one compofed of three fmall leaves ftanding upon one common footftalk, as the Alpine Ladies Smock, fee fig. 2. when thefe have no proper footftalk, it is termed (foliolis fefilibus) but when each has a proper footftalk (foliolis petiolatis).

When a leaf is compofed of two lobes (binatum) thefe fit upon a common footftalk, as in the Pafliflora bilobis, fee fig. 3 .

When it has many fmall leaves branching upon a common footitalk, it is called a branching leaf (ramofum) fee fig. 4.

A winged leaf (pinnatum) is compofed of many fmall leaves, ranged along on each fide the common footftalk like wings, as the Watercrefs; but as thefe are ranged in different manners, fo they have different appellations, viz.

When it is terminated by a fingle lobe or little leaf, it is an unequal winged leaf, (imparipinnatum) 
pinnatum) fee fig. 5 . when it is not terminated by a fmall leaf or tendril, it is called an abrupt winged leaf (abruptum) fee fig. 6.

When the fmall leaves are placed oppofits on the footftalk, as in fig. 6. it is called an oppofite winged leaf; but when they ars placed alternately, it is called an alternate winged leaf.

When the fmall leaves are alternately unequal, as in fig. 7 . it is called an interrupt winged leaf.

If it has clafpers or tendrils by which it faftens to any other body or fupport, it is called a (cirrbous) winged leaf, as the Vetcb, fee fig. 8.

When the fmall leaves have borders running along the footfalk from one to the other, as in fig. 9 . it is called a running winged leaf (decurrentibus).

When the footfalks have a jointed mernbrane between the fmall leaves, as in fig. 10. they are termed membranaceous footfalks.

When the leaf is compofed of one pair of little leaves placed oppofite, as in fig. I I. it is called a conjugated leaf.

A lyre-haped leaf (lyratum) is one lear whofe lower part is cut in fuch a manner, as if the fegments at the bafe were feparated from 
the body of the leaf, and detached from thofe on the top, as in the Fiddle Dock, fee fig. 12.

A double winged leaf (duplicato-pinnatum) or (pinnato-pinnatum) is a leaf compofed of leaves, which were compofed before of wings, as the Melia, or common Bead Tree, fee fig. I3.

A decompofite leaf (decompofita) is that whofe common footitalk divides twice before it is garnifhed with leaves, as in fig. 23 , and 24 . this is alfo called a double winged leaf, as the Rue (duplicato-pinnatum).

A fupradecompofite leaf is one whofe common foottalk divides feveral times before it is garnithed with fmall leaves, as in the Acbillea, fee fig. 19, and 22.

A double trifoliate leaf (duplicato-ternatum) is one which is compofed of two orders of trefoil leaves; and when the common footftalk is divided into three, each fuftaining three leaves, it is called a triplicate trefoil leaf (triplicato-ternatum), as the Barrentert, fee fig. 15 .

Of the determination of leaves.

The determination of leaves confirts in this difference, viz. that a leaf is diftinguined without any regard to its ftructure of form; this 
is divided into four orders, which confift in the direction, the place, the infertion, and the fituation.

I. The direction, fee fig. I6. is the expanfion which the leaf requires from the bottom to the top. If it is arched (inflexum), that is, when it returns toward the footftalk, as at $a, a$; when it is upright (erectum), that is, if it makes an acute angle with the footfalk, fee $b, b$. If it fpreads open, or ftands almoft in a right angle with the perpendicular $c, c$, it is called (patens); when it is hotizontal, that is, when it makes a right angle with the perpendicular, as at $d, d$, (borizontale); when the leaf is reclinated, or the fummit is turned fo that it is lower than the bafe (reclinatum), as at $e, e$; when it is turned back, or rolied, as at $f, f$, (revolutum), or a revolved leaf.

When a leaf puts out a radicle from its top, as fome of the ferns do, it is called radicans; if it puts out roots from its under furface, radicatum; and if they float on the water, natans.

II. The place, fee fig. 17. this is determined by the place where it is faftened to the plant; the feed leaf (feminale),$a$, $a$, is that which is firft put out from the feed, and is often called Cotyledon, or Seed-leaf. 
A radicle leaf (radicale) is one which rifes from the root, and is not faftened to the ftalk, $b$; thofe leaves which are faftened to the ftalk are ralled (caulinum) $c, c, c$, thofe which fit on the branches (ramofum) $d, d$, thofe which are under the ramifications or wings of the ftalk, (fubulare) e, e, and the floral leaf (florale) is always fituated near the flower.

III. The infertion is the manner in which a leaf is fantened to the plant, fee fig. 18.

A buckler or thield-Risaped leaf (peltatum) is one whofe footftalk is faftened to its difk, and not to the bafe or border $a$, as the Water Lily.

When the leaf has a footftalk at its bafe by which it is faftened to the plant as at $b$, it is called petiolatum.

If it is faftened to the branch without a footftalk as at $c$, (Seffle) fitting clofe.

When the bafe of the leaf is faftened by a membrane running along the ftalk as at $d$, decurrens, as in the White or Woolly Thifle. When the bafe of the leaf extends fo as to embrace the ftalk quite round, as at $e$, amplexicaule, as the Honeywort.

But when the lobes of the bafe are too fnort for to wholly embrace 'the ftalk, it is termed femiamplexicaule, half embracing. 


\section{the Science of Botany. 35}

A perfoliate leaf (perfoliatum) is one whofe difk furrounds the ftalk, the branch, or the footfalk, without any of the borders adhering to it, like the Hares Ear, commonly called Perfoliatum, as at $f$.

A coherent leaf (folia comata) is where the bafe of twio oppofite leaves unite, and appear to be but one leaf, as the Eafiern Myofotis, fee $a$; when the bafe of the leaf is like a cylinder, and furrounds the ftalk or branch like a theath as at $b$, it is termed (vaginans).

IV. The fituation of the leaves (Jitus) depends upon the pofition of each with regard to the others, fee fig. 2 I.

A jointed leaf (folia articulata) is one whofe fummits are joined to each other, fee fig. 20.

Starry leaves (folia fellata) are fuch as have fix or more fmall leaves furrounding the ftalk which are pointed like ftars, as at $a$, as the Goofegrass, or Clivers.

When there are but three of thefe leaves, they are termed ternata, as the Trefoils; when four, as at $b$, quaterna; when five, quina.

When two leaves are placed oppofite on the Atalk as at $c, c$, it is termed (folia oppofita) and when they are ranged one above the other as at $d, d$, (folia alternata) alternate leaves. 
When the leaves are fituated loofely without order upon the branches as at $e$, thiey are termed (folia Jparfa), fcattered leaves.

When there are many leaves fet upon a common footftalk, which are fo clofely placed as that their fituation cannot be eafily difcovered, they are termed (conferta) cluftered, as at letter $f$.

When they are ranged like the tiles of a houfe, or fcales of filh, imbricata, as at $g$.

But when the leaves are placed in clufters, proceeding from the fame point as at $b, f a f-$ ciculata, cluftered or bundled leaves.

Of the parts of fructification.

Thefe parts are either general or particular; the general are two, viz. the flower and the fruit. The particular are fubdivided into the eight following parts, viz. the impalement or cup (calyce), the flower-leaves, or petals (corolla), the ftamina (filumenta), the fummits (antbera), the pointal or fyle (Jyius), the pericarpium or fleihy fubftance which furrounds the feeds, as in Apple and Pear; the feed (Semina), and the receptacle or placenta to which the feeds are faftened. The five firft belong to the flower, and the three laft to the fruit. 


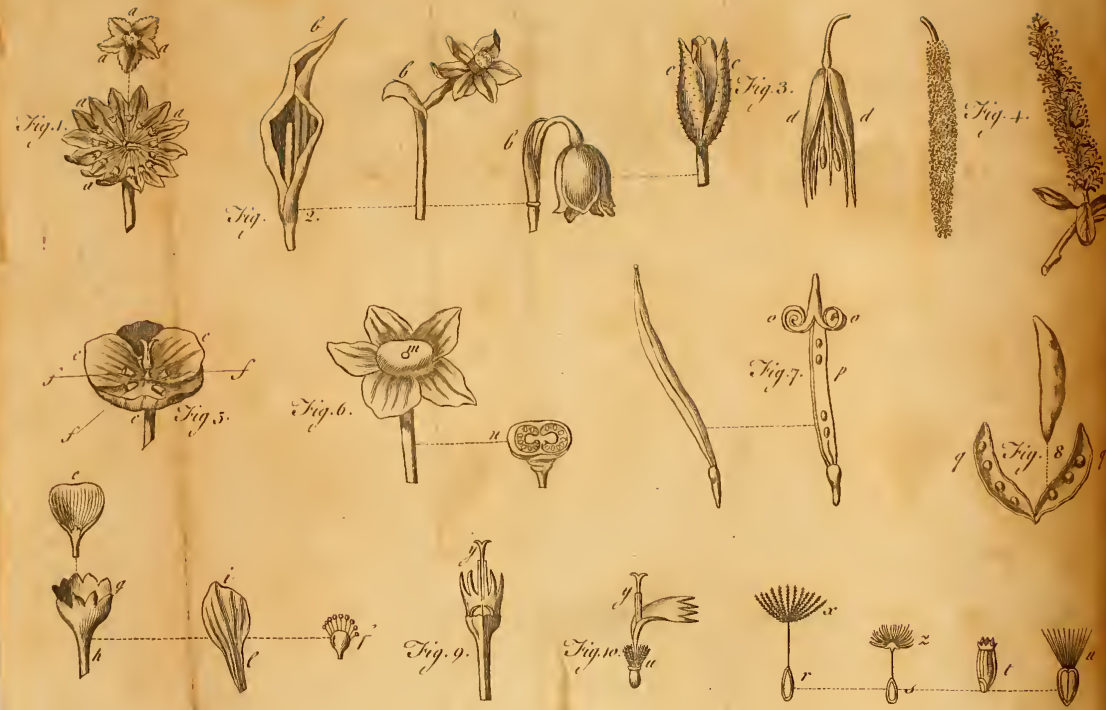

$\int_{0}^{2}=2$ 


\section{the Science of Botany.}

\section{The parts of the flower, plate IV.}

I. The cup of the flower (calyx), is that which inclofes or fuftains the other parts; thefe are divided into the feven following forts, the periantbium, the involucrum, the Jpatba, gluma, amentum or julus, calyptra, and volva.

The periantbium is the moft common fort of flower cup ; it is often compofed of many parts, or when it is of one part or piece, it is divided or cut half way into more or lefs parts; this always furrounds the flower.

The involucrum or outer cover embraces many flowers, which are collected together, and have each their proper periantbium. They are difpofed in form of rays, and are fometimes coloured; fee fig. I. $a, a, a$. This is often met with in the fecond order of Limnaus's fifth clafs, which includes the plants with umbellated flowers.

The Jpatba or theath is a particular fort of cover to one or feveral flowers, which feldom are provided with any particular periantbium ; it confifts of a membrane faftened to the ftalk, and is of different figures and confiftence, as the Arum, fee fig. 2. $b, b, b$.

It is fometimes compofed of two pieces, as at fig. 2. c, c; this often occurs in Linneus's I, III, VI, and XXth claffes. 
Giluna or chaff, is a fort of cover only belonging to the corns and graffes; thefe are compofed of two or three membranaceous valves, as at fig. $3 \cdot d, d$, which are often tranfparent on their borders.

A julus or katkin (amenium) is a mass of male or female flowers faftened to an axis in form of a rope, being covered will fmall fcales which ferve for calyces, fee fig. 4. thefe occur frequently in Linnceus's twenty-firft clafs.

The coif (calptra) is a thin membranaceous cover of a conick form, which covers the parts of fructification, and is often met with in many kinds of mofs on the top of the flowers.

The purfe (volva) is a thick fort of covering which inciofes feveral of the muhroom tribe, and opens lengthways to let them out.

II. The petal or flower leaf (corolla) is that which immediately furrounds the parts of generation; there are two forts of thefe, the petal and the nectarium. When it is of one piece, it is called (monopetalous) and when it is of many pieces, (polypetalous).

The flower leaf, or petal, is generally diftinguified by the beauty of its colour, fee $e, e, e$, fig. 5. When this is of one piece, it is diftinguifhed by the tube (tubus) $b$, and the limb or border (limbus) $g$, when the flower is 


\section{the Science of Botany.}

of many petals, each are diftinguifhed by their tail (unguis) $l$, and the blade (lamina) $i$.

The nectarium is that part of the corolla, which is deftined to contain the honey or fweet juice of the flower, and is of different figures, as a tube, a fcale, a pimple, or tubercle, fee $f, f, f$, fig. 5 .

A floret (corollula tubulata) confifts of one piece formed in a kind of tube or bell-rhape, cut at the top into four or five parts which open and turn backward, fee fig. 9 .

A half floret (corollula ligulata) confints of a flat narrow limb or tail turning outward, whofe fummit is either intire or indented in three or five points, fee fig. 10.

III. The ftamen is the male part of generation in flowers, and is compofed of two parts, the filament and the fummit.

The filament (filamentum) ferves to fuftain the fummit or apex; this is fometimes in form of a thread, and at others it is awl-hhaped.

The fummit (antbera), or apex, is the effential part of the ftamina, or the male organ of generation; it confifts of a little bag of one or more cavities, which is commonly faftened to the point of the filament, and contains the male farina.

$$
\text { c } 4
$$


IV. The pointal (pifillum) includes the female parts of generation in flowers, which is compofed of the germ (germen), the Atyle (flylus), and the ftigma.

The germ inclofes and defends the embryons of the feeds, and is properly the matrix of the plant.

The ftyle fits upon the 'germ, and fuftains the ftigma; but there are fome flowers which have no tyle.

The ftigma is the female organ of generation, and is of different figures; it is generally fituated upon the extremity of the ftyle; and when there is no ftyle, it fits upon the germ.

\section{The Parts of Fruit.}

The (pericarpium) is formed of the germ which enlarges and inclofes the feeds; fee $m$, n, fig. 6. it is divided into eight fpecies; the capfule, the fhell, the pod, the hufk, the nut, the apple, the berry, and the cone.

The capiule is compofed of many dry elaftick cells, which, when the feeds are ripe, generally open at the top; when it has but one cell, it is called unilocularis; if two, bilocularis; or if feveral, multilocularis.

The fhell (conceptaculum) is different from a capfule of one cell, in the cover being fof er, 


\section{the Science of Botany.}

and not fo rough; opening lengthways on one fide, and the feeds are not faftened to it.

The pod (filiqua) fig. $7 \cdot$ is compofed of two lids, 0,0 , which open from the bafe toward the point, feparated by a diaphragm or membraneous partition, to which the feeds are faftened by an umbilical cord.

A leguminous pod (legumen) fig. 8. is an oblong cover of two thells joined above and below by a longitudinal future; the feeds, $q, q$, are faftened alternately to the upper border of each thell. Moft of the pulfe are of this kind.

A plum' (drupa) is a fruit compored of a flethy foft plup inclofing a nut or ftone in the middle.

A berry (bacca) inclofes many naked feeds in the middle of a fucculent pulp.

An apple (pomum) is a fruit compofed of a folid flefhy pulp, in the middle of which are little cells with membranaceous covers, in which the kernels or feeds are inclofed. .

A cone (Arobilus) is a hard dry fruit, generally of a conical form, compofed of many fcales lying over each other like the tiles of an houfe, or the fcales of firh.

VI. Seeds are alfo diftinguifhed into two forts, viz. nuts, and grains or feeds.

The nut is a fruit with a hard thell, inclofing the true feed. 
The, feed (femen) is of all forts of figures, and is that part which vegetates and produces a plant of the fame kind with that from which it was taken; the feeds are fometimes adorned with a crown.

The crown (corona) is either fimple as at fig. II. $t$, or tufted, as at fig. IO and II. $x$, $z, u$. When the down or tuft fits clofe upon the feed, without any footftalk, or fupport, as at $u$, it is termed (Jefflis); but if it has fupports, as at $r, x, s, \approx$, (Aipite infldens), each of thefe tufts are again divided into fimple and branching, the fimple, $u, x$, is compofed of fingle rays; and the branching, $u, x$, fig. $I O$ and II. of bearded or feathered plumes.

The receptacle (receptaculum) is the placenta upon which is placed the flower, or fruit, or both together, and is of different figures.

An Explanation of the Ciasses.

\section{Plate V.}

Plants have flowers vifible or almort invifible; the vifible flowers are either hermaphrodite, that is to fay, they are each furnifhed with ftamina and pointals; or of one fex, either all male, when they have only ftamina and no

pointals, 



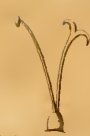

(x).

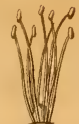

:Xig. $y$.

-

I IMVili?

y.

no

:Yiig. 13.

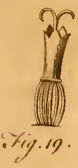

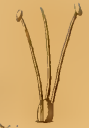

Ding. 2.

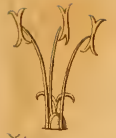

itig 3.

: Yiig. 8 .

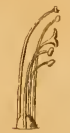

SYig. 1 .

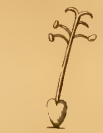

:Yig.20.

(Yiig. 21.

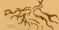

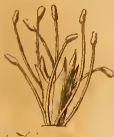

:Xig. 9

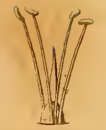

Ying.t.

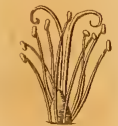

(Y).ig. 11 .

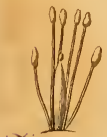

: $x, 1,1,1,5$

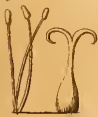

:Y.iig. 16.

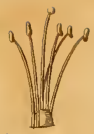

Mriy.5.5

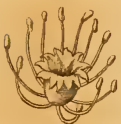

ivin. 11.
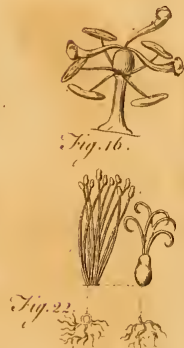

Yily.2य

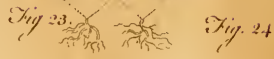
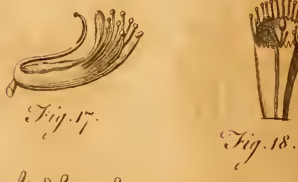

YYig. 18.

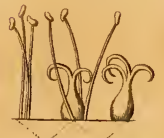

iYiy. 12.
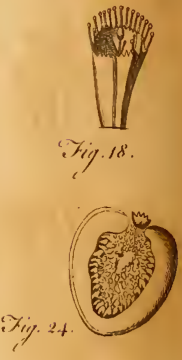


\section{the Science of Botany.}

pointals, or all female, when they have pointals without ftamina.

The ftamina are either detached from each other, or united together by one of their parts, as alfo fometimes with the pointal.

The famina are not of equal length, or there are conftaritly a certain number which are fhorter than the reft.

The claffes of plants which are eftablifhed upon the principles of the fexes, are diftinguifhed according to the number, proportion, and the fituation of the ftamina in their flowers.

The plants which have hermaphrodite flowers.

Fig. I. (Monandria) with one ftamen.

Fig. 2. (Diandria) two ftamina.

In this clafs the learned author has ranged feveral genera, which would with greater propriety come in his fourteenth clafs, intituled Didynamia; the flowers and fructification agreeing in every refped with thofe of the fourteenth clafs, excepting the number of their ftamina, which in thofe of this fecond clafs have but two, and the other have four, two long and two fhort : however, in Salvia there are generally four ftamina, two of which are of thort duration, feldom lafting one day after the flower is 
npen, before they fhrink up : but in that time they nay have difcharged their farina, fo anfwered the intended purpofe, therefore fhould by no means be feparated from their congeners. The learned Doctor Van Royen, late profeffor of Botany at Leyden, has joined all thefe plants in the fame clafs, titling it Ringentes Gymnofpermice; he alfo has ranged feveral other genera of Doctor Linnaus's fecond clafs, under the firft order of his twelfth clafs, called Ringentes Angiopperme.

Fig. 3. (Triandria) three famina.

In the third class Doctor Linnaus brings all the liliaceous plants whofe flowers have three ftamina in each, by which they are feparated from their congeners, which are ranged in his fixth clafs; therefore it would have approached nearer to a natural method, if thofe plants whofe flowers have but three famina in each, were ranged immediately before thofe whofe flowers have fix, in the fame clafs: and if all the graffes were joined in one clafs, ranging thofe whofe flowers have but two ftamina firft, and thofe with three following them, and then thofe with fix, $\mathcal{E}^{2} c$. it would ftill be nearer nature, than dividing them into fo many different claffes.

Fig. 4. (Tetrandria) four famina.

Fig. 5. 


\section{the Science of Botany.}

Fig. 5. (Pentandria) five Atamina.

Fig. 6. (Hexandria) fix ftamina.

Fig. 7. (Heptandria) feven ftamina.

Fig. 8. (Oztandria) eight ftamina.

Fig. 9. (Enneandria) nine ftamina.

In the ninth clafs is ranged Laurus, whereas all the different plants ranged under that generical title, have male flowers upon different plants, from thofe which produce fruit, fo with more propriety mould be placed in the twenty-fecond clafs, titled Dicecia; but as the learned author may not have had opportunities of feeing the frem flowers of many of thefe plants, fo he has been obliged to take his characters either from dried famples, or from imperfect defcriptions, fo may have been eafily led into there miftakes.

There are alfo in fome of his other clafies the like miftakes with thofe before mentioned, which may have happened from the fame caufes; however, upon the whole, there is certainly great merit due to this author for his difcoveries.

Fig. 10. (Decandria) ten ftamina.

Fig. I I. (Dodecandria) twelve famina.

Fig. I2. (Icofandria) when there are more than twelve, and thefe are faftened to the interior part of the flower cup, and not to the receptaculum.

Fig. 13 . 
Fig. 13. (Polyandria) when there are more than twelve, which are faftened to the receptaculum.

The plants whofe flowers have two ftamina thorter than the other, are diftinguined in the following manner.

Fig. I4. (Didnnamia) thefe fowers have two long and two thorter ftamina.

Fig. I 5. (Teiradynamia) thefe flowers have four long and two horter ftamina.

Thofe plants whofe flowers have their ftamina united together, or with the pointal, are diftinguifhed in the following manner.

Fig. 16. (Monadelpbia) thefe have all their ftamina united by their tails into one body.

Fig. 17. (Diadelpbia) thefe have all their ftamina united by their tails into two bodies.

Fig. I8. (Polyadelplia) thefe have all their ftamina united by their tails into three or more bodies.

Fig. 19. (Synzenefin) thefe have all their ftamina united by their fummits in form of a cylincer.

Fig. 20. (Gynandria) the ftamina of thefe fit upon the pointal, and not upon the receptaculum. 


\section{the Science of Botany.}

Thofe plants whofe flowers are of different fexes are thus diftinguilhed.

Fig. 2I. (Moncecia) the plants of this clafs have male and female flowers upon the fame individual.

Fig. 22. (Diocia) thefe have male and female flowers upon different plants.

This clafs of plants is fubject to variation, for feveral plants included in it by the author, which when young produce only male flowers, but after fome years growth, have produced fruit which have grown and produced plants of both fexes.

Fig. 23. (Polygamia) thefe have hermaphrodite flowers, with flowers of one fex, either male or female upon the fame individual.

Thofe plants whofe flowers are inclofed in the fruit, or are fo fmall as not to be feen by the naked eye, are included in the $24^{\text {th }}$ clafs, intituled Cryptogamia, fee fig. 24 .

In this clafs our author in the former editions of his method ranged Ficuls, which in the laft edition he has removed to his clafs Dicecia, but it thould rather be placed in the clafs Monoecia; for all the fruits which I have examined of the different kinds of Figs, have male and female flowers in the fame covers, and do ail 


\section{8}

produce good feeds : but being generally within the finin or covers, are feldom feen unlefs they are opened.

\section{An Explanation of the ORders.}

The orders or fubdivifions of the claffes are eftablinied upon the pointals, as the claffes are upon the famina, the number of pointals taken to the bafe of the ftyle, and when there is no ftyle, the itigmas are counted.

\section{The order of the I $_{3}$ firf claffes are,}

I. (Monogynia) flowers with one pointal.

2. (Digynie) thofe with two pointals.

3. (Trigynia) with three pointals.

4. (Tetragynia) with four, Ec.

When the flower has a great number of pointals, Polyginia.

The I4th Clafs (Didynamia) is divided into the two following orders.

I. (Gymnopermia) thefe have four naked feeds fucceeding each flower fitting in the cup.

2. (Angioppermia) the feeds of thefe are inclofed in a cover.

The I $5^{\text {th }}$ clafs, (Tetradynamia) is alfo divided into two orders. 


\section{the Science of Botany.}

I. (Siliculofa) Mort poded, the pericarpium or cover is fuborbicular, and garnifhed with a ftyle of the fame length.

2. (Siliquofa) long poded, the pericarpium of this is long, with a fyle fcarcely feen.

The I $g^{\text {th }}$ clafs (Syngenefia) is divided into the five following crders.

(Polygamia) is a fower compofed of many florets.

I. (Polygamio aqualis) is a flower compofed of hermaphrodite florets, in the dink and the circumference.

2. (Polygamia Jupergun) the flowers of this order are compofed of hermaphrodite florets in the dif, and of female in their circumference.

3. (Polygamia friftranea) have flowers compofed of hermaphrodite florets in the dik, and of neutral in their circumference.

4. (Polyzamia neceffaria) the flowers of this order are compofed of male florets in their difk, and of female in their circumference.

5. (Monogamia) is a flower which is compofed of fimple florets.

The fixteentin clafs (Monodelpbic), the feventeenth (Diadelplia), the eighteenth (Poliadelpbia), the twentieth (Gynondria), the twentyfint (Monocecia), the twenty-fecond, (Dioccia), 


\section{An Introduction, \&c.}

and the twenty-third (Polygamia), eftablifh their orders upon the claffical characters of thofe of the preceding claffes.

The laft clafs (Cryptogamia), in fhort, is divided into as many orders, as the families which compore it.

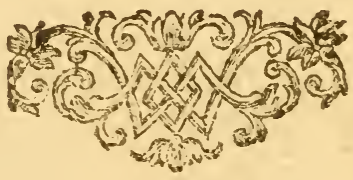




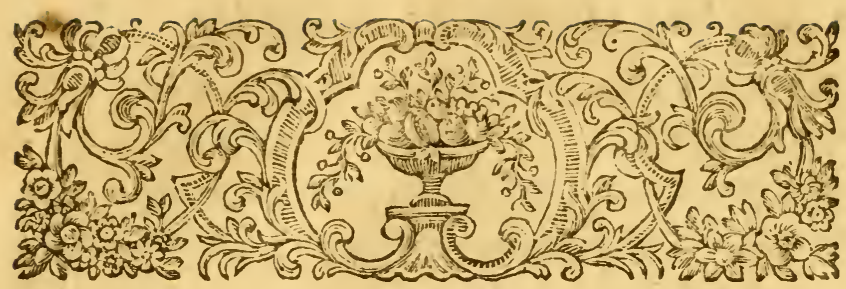

T H E

\section{Gardeners Kalendar.}

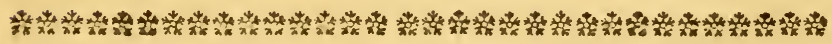

\section{J A N U A R Y.}

Work to be done in the KITCHEN= GARDEN.

2015e9 $\mathrm{F}$ the weather in this month is 6. . (1) to fweeten, that it may be foon made ready for fowing or planting the following months: for by expofing of the earth thus in ridges to the froft, it will be greatly mellowed, and rendered fertile; and a great quantity of land may be foon levelled for fowing, which would require much time to dig in a proper manner; whereby there will be no occafion to flight this work, as is too often the 
cafe when the ground is to be dug at the time when the crops are to be put in. On warm borders and banks, near walls, pales, or hedges, you may now fow Radirh, Carrot, and Lettuce feeds; and in warm fituations fow fome Peas, and plant Beans to fucceed thofe which were planted in the former months. You may now plant the firft crop of Windfor and Sandwich Beans, about the middle of this month, which will come in to fucceed the early Beans to fupply the table when they are going off. The Sandwich Beans may be firf planted, being hardier than the Windfor; therefore are preferred by the market gardeners, how have more regard to the quantity, than the quality of their crops; but the Windfor Beans are by much the beft fort for the table.

If the froft hould prove very fevere, it will be proper to cover the ridges over the roots of Artichokes, either with old tanners bark, horfe dung, litter, or fern, which ever can be moft afily procured, to prevent the froft from penetrating fo far into the ground, as to deftroy the Articholses; the neglecting of this, has very often proved fatal to thefe in very tharp winters.

When this month proves feverely cold, and the gromind is frozen fo hard as not to be dug (as it often happens), then you may carry dung and 
Jan. The Gardeners Kalendar. and fpread it upon the ground, repair hedges, rub out and clean your feeds, and prepare fhreds and nails for thofe trees which are to be pruned in the next month : and get all the Garden-tools ready for ufe when the weather is mild, that you may not be hindered with thefe things when every other part of the bufinefs is in great hafte; for if, in this and the next month, you omit putting in your crops, whenever the weather will permit, you will find a great lofs attend it the following fpring and fummer, efpecially in dry land.

Make a hot-bed for fowing early Cucumbers; and as there is fome hazard of the plants fucceeding at this feafon, efpecially in bad years, or where there is not due care taken in their attendance; fo there Thould be fome feeds put into the bed at three or four different times this month, that if fome hould fail, the others may fupply their lofs: there hould alfo be one or two hot-beds made at about three weeks diftance from each other for to force Afparagus, to fucceed thofe beds which were made the laft month, that there may be no want of it in the kitchen, where it is required during the winter reaton.

Sow Crefies, Muftard, Rape, Radif, Turnep, and other forts of fmall Sallet-herbs, upB 2

on 


\section{The Gardeners Kalendar. Jan.}

on moderate hot-beds to bring them forward; for thofe feeds which are fown in the full ground feldom fucceed: thofe perfons who have no frames to fpare, may arch the beds with hoops, and cover them with mats, which will be fuffient covering in any moderate feafon; or if, in fevere winters, the mats are covered with ftraw to keep out the froft, the fmall Sallet-herbs will come up in thefe beds, though the plants will not thrive fo well as thofe covered with glaffes.

Earth up Celery to blanch it, when the weather is open, and the ground not too wet, for the plants cannot be too much guarded from froft, by earthing them up at this time. And, in very hard froft, fome of the Celery, as alfo the ridges of Endive which were put into the ground to blanch, Mould be covered with long litter, or tanners bark, to keep the froft out of the ground, otherwife when the ground is frozen, they cannot be taken up for ufe when they are wanted. You muft alfo in open weather, draw up the earth to your early Peas and Beans, which will greatly protect their ftems from froft; but this hould be done when the furface of the ground is dry, left the moifture of the earth thould rot their tender ftalks. But in doing of this, great care thould be

had, 
Jan. The Gardeners Kalendar.

had, not to bury the tops of the plants with earth.

The Murhroom-beds muf now be carefully covered with long frefh ftraw, and the old covering removed, for at this feafon the ftraw foon becomes rotten with moifture, fo there can't be too great care taken of thofe beds to preferve them from the froft, and alfo keep off the wet, both which are deftructive to them at this feafon; for which reafon fome perfons cover the beds with frames, which is a very fecure method where frames can be fpared.

In mild weather, you may tranfplant fome of your beft kinds of Endive plants on a warm border, for feed; in doing of which, you fhould be careful to lay the border a little floping, that the wet may not lodge about the plants: and be very careful to make choice of the ftrongeft plants, which have the greateft number of leaves, and if it be the curled Endive, thofe plants mut be chofen whofe leaves are moft curled; otherwife you will degenerate the fort, in two or three years, fo as to become almort plain.

Look carefully to your Cauliflower plants, which are under frames, pulling off all decayed leaves from them, which, if permitted to remain upon them, would endanger the plants, 


\section{The Gardeners Kalendar. Jan.}

efpecially if the weather hould prove fo bad, as that the glaffes could not be opened for three or four days together to give them air, which fometimes happens at this time of the year; when thefe rotten leaves will caufe the inclored air in the beds to turn rancid, to the great prejudice of the plants; therefore you fhould always pick them off as foon as they turn yellow, and be fure to give the plants as much air as poffible, when the weather will permit ; otherwife they will draw up weak, fo will not be able to refift the cold of the open air the next month, toward the end of which, if the feafon is mild, they hould be planted out where they are to remain; and where there are Cauliflower plants under bell or hand-glaffes, which are defigned to come early, the glaffes fhould be conftantly raifed on one fide with props in mild weather, to admit air to the plants, for the fame reafon. But in frofty weather the glaffes murt be fet down as clofe as poffible to prevent the Marp winds from getting under the glafies, which may kill or greatly injure the plants.

Thofe who have Cucumber and Melon plants already up, muft be very careful of them at this feafon, otherwife a fmall neglect will deftroy them all. Therefore the beds munt 


\section{Jan. The Gardeners Kalendar.}

be conftantly kept to an equal temperature of heat, and air muft be given to them at every opportunity, that the fteam of the bed may pafs off; but this muft be done with great caution; for if too much cold air be admitted, it will be equally deftructive to the plants; fo that the great art in raifing thefe plants carly, depends upon the careful obferving all the changes and alterations of the weather, and the temperature of the beds: for as the outward air is frequently very cold at this time of the year, fo the hafty admifion of it to tender plants may foon deftroy them; therefore it will be proper to place a coarfe cloth before the front of thofe glaffes, which are raifed to give air, to prevent its too freely entering the bed, which may give a fudden check to the plants.

When it fo happens, as that by fevere froft, or any other accident, your Caulifower plants are deftroyed, which were raifed in the autumn, which, in very fevere winters, fometimes has been the cafe, and was formerly fo more often than of late years, then you hould (fo foon as the weather will permit) make a gentle hotbed, and fow fome feeds thereon, to raife a new fupply of plants; which, if carefuily raifed, will produce very good heads in about three

$$
\text { B } 4
$$

weeks 
weeks or a month after thofe which were raifed in autumn, provided the young plants are planted upon a frefh hot-bed as foon as they are fit to remove, to bring them forward. In like manner you Thould alfo raife fome Cabbage plants, when your firf crop has been deftroyed. For want of this care to fow feeds of thefe after very fevere winters, many times people have lon all the forward feafon, fo have not had a fupply of thefe things for the table till very late in the fummer.

The Afparagus-beds, which were nuade the laft month, will now begin to have fome buds appear, when you mult earth them the full thicknefs over the crown of the roots, which fhould be five or fix inches at leant; and the frames Thould now be put over them: but if you find the heat of the bed begin to decline, it will be neceffary to add fome hot dung round the fides (which, in the gardeners phrafe, is called lining the beds); this will renew the heat of the bed, and bring the Afparagus forward; you hould obferve alfo to cover the glafles put over the beds with mats and fraw every night, and in bad weather, and when there is no appearance of fun, the covering may remain on all the day, till the Afparagus appears again through the earth with which is was laft covered; 


\section{Jan. The Gardeners Kalendar.}

vered; but after the buds are come thro' the earth, the covering of mats and fraw fhould be taken off every day if the weather will permit, otherwife the Afparagus will be white, which renders it lefs efteemed by the Englifh.

Towards the end of this month you may tranfplant Carrots, Parfneps, Leeks, and Cabbages, for feed, if the feafon proves mild ; obferving to hang up the Cabbages by their ftalks under cover in a dry place, three or four days before they are planted; obferving to take off the outer leaves, that the water may drain out from between their inner leaves to prevent their rotting. Thefe thould be planted near a hedge, pale, or wall, where they may be fheitered from ftrong winds, which often break down their branches of feed in fummer, when they are too much expofed thereto; but in the doing of this, you muft never plant more than one fort in the fame place: for where red and white Cabbages, or Savoys, are fuffered to produce feeds near each other, the farina of their flowers will intermix, and thereby the forts will be degenerated; and it is by the not obferving this method, the Englifh gardeners feldom preferve the red Cabbages good and right in their kind long, and fuppore it is owing to the foil and climate; therefore this feed is frequently 


\section{The Gardeners Kalendar. Jan.}

frequently bought of the Dutch, who are very careful in faving this particular fort of feed, never fuffering any oiher fort of Cabbages to ftand near them for feeds: for the fame variation frequently happens, where Savoys are planted near Cabbages for feed; therefore to preferve thefe right, each fort hould be planted by itfelf for feed, to preferve them from varying.

Make fome gentle hot-beds the beginning of this month, for to plant fome Tanfey and Mint, which, if carefully managed, will be fit for ufe all February and Marck; after which time the beds in the open air will fupply the kitchen.

If the former month, or the beginning of this, has proved fo fevere as to deftroy the carly Radimes and Carrots, which were fown on warm borders, you muft make fome gentle hot-beds to fow fome Radifhes upon to come early, fo foon as the weather will permit to do this work, to fupply the table in the fpring, before thofe can come which are now to be fown in the open air : but thefe hot-beds muft be earthed eight or nine inches deep, otherwife there will not be depth enough for the roots to run down before they reach the dung, which will fop the roots from going farther. There fhould alfo be fome feeds of each fort fown on warm borders in the open air as foon as the 


\section{Jan. The Gardeners Kalendar.}

weather will permit, to fucceed thofe fown on the hot-beds.

Tranfplant Endive into trenches to blanch, when the weather is open and dry; in doing of which, you muft obferve to lay the trenches floping, that the wet may pafs off; and put the Endive on the fide of the ridge, towards the fun, and at about fix inches from the top of the ridge, thrufting the plants into the earth almoft to the extremity of their leaves; where there is the conveniency of a covered hed, the plants thould be hung up by their roots for one night, that the wet may drain from between their leaves before they are put into the trenches; this will be a good method to prevent the Endive from rotting. But in very fevere winters, the Endive is frequently killed, which is not put into the trenches to blanch before the froft fets in, unlefs the borders where it grows are well protected from cold by a covering of mats or frraw; therefore thofe perfons who defre to have Iñdive all the fpring, thould be at the expence of covering the plants in hard winters.

You may now defroy fnails, and nther vermin, which at this feafon are clofely laid up in the holes of walls, and under reed-hedges, and fuch other places of helter, but efpecially 
1 The Gardeners Kalendar. Jan. behind the Atems of wall trees and in empty pots, where they may be eafily taken before they get abroad.

Towards the end of the month, if the weather is open, there muft be fome more Peas and Beans put into the ground to fucceed thore before planted, that there may be a conftant fupply for the table or market from the beginning to the end of the feafon. There mould alfo be fome Spinach, Carrots, and Lettuce of the common or brown Dutch forts, forn on warm borders. Thefe fowings mould be repeated every fortnight or three weeks, provided the weather will permit, that if the forward fowings are deftroyed by froft, there may not be wanting any of thefe crops in the kitchen-garden in the early feafon.

Toward the end of this month, you may fow fome Parfley in drills; and alfo fome Chervil; for as thefe feeds lie a long time in the ground, fo there will be little or no danger of their being injured by the cold.

Products of the KITCHFN-GARDEN.

You have now Cabbages, Savoys, Parfneps, Turneps, Carrots, Potatoes, Leeks, Onions, Garlic, Shallots, Rocambole, Beets, Borecole, 


\section{Jan. The Gardeners Kalendar.}

\&c. in plenty; as alfo Celery, Endive, and Rampion roots, and on hot-beds Lettuce, and all forts of young Sallet-herbs, as Creffes, Turnep, Radith, Rape, Muftard, Coriander, Chervil, Tarragon, and Mint; and Afparagus on hotbeds made the latter end of November: you have alfo Skirrets, white, red, and purple Broccoli, Salfafy, Scorzonera, and large Parlley roots, Mufhrooms, Sorrel, Burnet, Parlley, Sage, Rofemary, Thyme, Hyffop, Winter-Savory, Coleworts, and Sprouts from the Cabbage and Savoyftalks, which were cut in Oetobér and November, Spinach and Cardoons, leaves of the white and card Beets, with fome other Soup herbs. And under frames you may have brown Dutch Lettuce well cabbaged, with proper care.

Work to be done in the FRUIT-GARDEN.

Cover the roots of all new-planted trees with mulch to guard them from the froft, provided it be not already done, or that it may have wafted; and the Fig-trees which are againft walis, pales, or efpaliers, thould be covered either with mats or reeds; which will preferve their tender thoots from being injured by froft, and caufe the fruit to come out much earlier in the fpring, and in greater quantity; 
14 The Gardeners Kalendar. Jan. but before this is done, you hould diveft the branches of all the autumnal Figs, if there are any remaining on; otherwife thefe will decay, and infect the tender fhoots, which fhould produce fruit the fpring following. Wherever this method is practifed, there fhould be great care taken, not to expofe the trees too fuddenly to the open air ; but remove the coverings gradually, when the weather becomes warm. And where there are Fig-trees planted in efpaliers, it will be a good method to loofen the branches from the trellifs, and either lay them down, or tie their branches together, covering them with dry litter or Peas haulm, which will preferve their branches from being killed by the froft, and hereby a good crop of Figs may be generally obtained.

You may now cut out all the dead or cankered branches from your ftandard fruit-trees; as alfo fuch as crofs each other, and are ill placed; but be careful in doing this, to make the wounded part as fmooth as poffible, and noping, that the wet may not enter and be detained there, to the great prejudice of the trees.

If the feafon be mild, you may prune dwarf trees of any hardy forts of fruits, as Pears, Apples, Vines, Goofeberries, Currants, and 
Jan. The Gardeners Kalendar. I5 Rafpberries; but ftone fruit (which was not pruned in autumn) thould be deferred until the end of the next month, or the beginning of March ; becaufe if hard froit thould follow foon after they are pruned, it will penetrate the wound of the tender hoots, and injure them.

In moift weather you may clear your fruittrees from mofs, wherever they are infefted with it; which may now be eafily fcraped off with iron inftruments, made hollow in fuch a manner as to fit the branches of the trees; but thefe inftruments muft not be made too tharp, left, by being incautiouly ufed, they hould wound the bark of the trees.

Cut grafts from all the forts of early fruits in mild weather, toward the end of this month, or the beginning of next, according as the feafon is more or lefs forward, laying them in the earth clofe to a dry wall or pale; and, if the weather fhould be fevere, they frould be covered with litter or ftraw, to protect them from injury. The reafon for cutting them fo early, is to prevent their buds from fwelling too much; therefore, as the winter proves the more or lefs fevere, fo you mufr be directed to cut the grafts fooncr or later, according as the trees are difpofed for budding. In the choice of thele, 
I 6 The Gardeners Kalendar. Jan. you fhould prefer fuch as grow upon the fruitful branches of healthy trees, and that have good buds to them.

In mild weather you muft prepare fuch borders as are defigned for planting with fruittrees the fucceeding month, laying a good quantity of frefh earth thereon, making it level, that it may have fome time to fettle before the trees are planted. You may alfo repair the borders about old fruit-trees, which want amendment, by laying fome frefl earth and well-rotted dung upon them; if the foil is cold and moift, then the rotten dung from the old Melon and Cucumber-beds, will be the moft proper; but where the foil is hot, neats dung is by fa: the beft; or where that cannot be had, rotten hogs dung is very good manure for fruittrees; thefe being naturally colder than any other fort of dung, will keep the earth cool about their roots in the fummer feafon. Whereever any of thefe dungs are applied to fruittrees, they fhould be thoroughly rotted before they are laid on the borders, otherwife they will do more harm than good. But if the trees are old, it will be of little fervice to add this near their ftems; for the roots which fupply them with nourinment, are extended to a confiderable diftance: therefore the whole mould 


\section{Jan. The Gardeners Kalendar.}

chould be mended to the diftance of fourteen feet from the ftems, where the borders are wide enough to admit of it, that the young roots may receive nourifhment therefrom.

Mend and repair all your decayed efpaliers with new poles, where they want them, and faften fuch places where the poles or rails are loofe, with wire, which is the ftrongeft faftening. You muft alfo train and tie the branches of your fruit-trees thereto with fmall ofier twigs, but obferve to place their branches regularly at proper diftances, never to crofs each other, and not to faften them fo clofe with the twigs as to pinch the Moots, when they fhall have grown larger the following fummer.

You may yet plant Strawberries and Rafpberries, if the weather is mild, and the ground in proper order, tho' it would have been better if done in autumn, efpecially where the foil is dry. Thofe who are curious to have early Strawberries, fhould now plant them in pots filled with good earth, and place them in a Theltered fituation till they are rooted; after which the pots fiould be plunged into a moderate hot-bed, which will bring them fo: ward in a Mort time; though it would have been much better if thefe had been planted into the pots in October, that they might be well rooted before they are put 


\section{8 The Gardeners Kalendar. Jan.}

on the hot-bed, whereby they would be capable of bearing a much larger quantity of fruit than thofe which are newly tranfplanted; or if they were planted into pots at this feafon, and kept in a hady fituation all the following fummer, keeping the plants always clear from runers, shey will be in good order to force the next feafon. But where there has not been a provifion made of thefe plants in time, the plants fhould be tranfplanted with good balls of earth to their roots, and put upon the hot-bed, and in this cafe there will be no occafion for planting them in pots; but it mutt be obferved, that the plants thould have been kept clear from runners, and to fingle heads the foregoing fummer; for if they were permitted to fend out fuckers from their fides, the principal roots will have been fo much weakened, as not to be in a condition to produce much fruit when they are forced. The earth of the hot-beds wherein the Strawberries are planted, fhould be loamy and ftrong, but not enriched much with dung, which will only add to the luxuriance of the plants, and prevent their fruiting in plenty. Thefe hot-beds muft not be kept covered too clofely; but whenever the weather will permit, the plants thould have a large mare of air, efpecially when they are in flower, 
Jan. The Gardeners Kalendar.

otherwife the bloffoms will fall away, and not produce much fruit; at which time the plants will alfo require to be frequent'y refrehed with water, otherwife the bloffoms will fall off, without having fruit to fucceed them, but the waterings muit be performed with difcretion.

Thofe perfons who are very curious to have early fruit in forcing-frames, muft now begin to add their heat, whether it be dung or fire which they ufe; but, for the earlier fruits, fire is better than dung, becaufe the heat of that may be kept more equal; for the dung at this feafon, efpecially where it is expofed to the weather, being often damped by great fnows, or too much wet, is very fubject to lofe its heat; and when the trees have been forced, there muft be great care taken to keep up the heat; for if, after the trees have been forced out into bloffom, they are neglected, and the air within the glaffes is not kept nearly to the fame temperature of heat, the bloffoms will fall off, and no fruit will fucceed them. There fhould alfo be the fame care taken to let in frem air whenever there are opportunities, for if they are kept too clore, they feldom fucceed well; therefore it is not proper to apply the heat too early to the trees, becaufe this monthis often unfavourable to tender blofforms, when the exernal 
20 The Gardeners Kalendar. Jan. air is generally too cold to be admited to them; fo that, if the heat be not applied before the beginning of this month, the bloffoms will not appear till the beginning of the next, when the weather is generally lefs fevere than in this; fo that there will be lefs danger of mifcarrying, and the fruit will be ripe almoft as early as thofe which were forced all December.

\section{Fruits in Prime, or yet lafing.}

Pears; L'Effacherie, Colmar, Virgoleufé, Ambrette, Epin d'Hyver, St. Germain, St. Auguntine, Winter Beurre, Martin Sec, Winter Boncretien, Citron d'Hyver, Rouffelette d'Hyver, France-Real, Bugi, or Bergamot de Pafgue, Bergamot d'Holland, Mufcat Alleman, Ronville, Portail, Befi de Caiffoy St. Martial, and Befin de Chaumontelle from efpaliers, which will keep near two months longer, than thofe from good afpected walls; and for baking, the Cadillac, Black Pear of Worcefter, and the Pickering.

Apples; Golden Pippin, Nonpareil, French Pippin, Golden Rufiet, Wheeler's Ruffet, Pile's Rufiet, Harvey Apple, Kentin Pippin, Holland Pippin, Aromatic Pippin, Kirton Pippin, Winter Pearmain, Monftrous Rennet, Pear

Ruffet, 
Jan. The Gardeners Kalendar.

Ruffet, Aromatic Ruffet, John Apple, Winter Queening, Pomme Roy, Pomme d'Apis, Winter Gilliflower, with many others of lefs note; as alfo Nuts, Almonds, Services, Medlars, and Grapes, where they have been carefully preferved; by cutting the bunches with a knot or joint of the vine, and hanging them in rows, in a dry warm room, at fuch diftance as not to touch each other, and that the air may pafs freely between them, otherwife they will foon grow mouldy and rot. By this method Grapes have been preferved good until the end of February, but it muft be the Frontiniac, and other late forts, which hould be thus treated.

Work to be done in the PLEASURE-GARDEN and WILDERNESS.

In frofty weather you hould cover the beds of Ranunculufes, Anemonies, Hyacinths, and other choice flowers: fuch of them as are not come up above-ground may be covered with tanners bark, peas haulm, or fome other light covering, but fuch of the beds of flowers as are come up, muft be arched over with hoops, and covered with mats or cloths; for if they are not protected from the froft at 
22 The Gardeners Kalendar. Jan. this feafon, their leaves will be killed, whereby the roots are many times deftroyed, or at leaft greatly weakened; but in mild weather they hould be uncovered, and expofed to the air as much as pofiible; for if they are ton clofely covered, they are apt to take damp and mould, which frequently caufes them to decay: wherever this covering is practifed, it fhould be continued until the weather is become warm, otherwife it is better not to ufe it; for by being covered, the plants will become tender, and fo will be lefs able to refift the cold, than thofe which have been conftantly expofed to the open air.

The Hyacinths, Narciffufes, and other bulbous-rocted flowers, whofe leaves do not yet appear above ground, may be covered over with tanners bark, which will prevent the froft from penetrating the earth, which in fevere winters, where there is no covering, frequently deftroys the roots. And in wet land, where the beds are raifed much above the paths, there thould be tan, litter, or dung, laid in the paths to raife them, otherwife the froft will enter through the fides of the beds to the roots, and greatly weaken or kill thofe on the out-fides of the beds. This method is conftantly practifed by the florifts in Holland, 
fan. The Gardeners Kalendar.

who preferve their flower roots much better than the Englifh gardeners generally do, though the winters there are commonly more fevere than in England.

Cover all pots and tubs of feedling flowers in hard frofts, and alfo from great fnows, which are very injurious to them, efpecially to the feedling Hyacinths, Perfian Irifes, Spring $\mathrm{Cy}-$ clamen, Ranunculufes, Anemonies, Narciffufes, and fome other bulbous and tuberous-rooted flowers, which, though hardy enough to refift the cold of our climate, when their roots are fully grown, yet, while young, are in danger of being deftroyed by fevere froft. And where thefe pots or tubs are not piunged into the earth, there hould be tan, litter, or dung, laid about them, to prevent the frof from entering thro' their fides.

In mild weather you may plant fuch roots of Ranunculufes, Anemonies, and Tulips, as were kept out of the ground to retard them, that they may fucceed thofe which were planted in autumn; but this fhould not be done when the earth is over wet, which would endanger the rotting of their roots; and if there Thould happen to fall much rain after they are planted, or hard froft hould foon after follow, the beds muft be covered with mats, ftraw, or 
24 The Gardeners Kalendar. Jan. peas haulm, otherwife the roots will be in great danger of perifhing.

Turn over your heaps of compoft, that the froft may mellow them, and break the clods: the oftener thefe are turned, the fooner they will be fit for ufe. You hould alfo, at this feafon, make new heaps of compoft in mild weather, when there is more leifure for doing it, than when the feafon is farther advanced, and many other neceffary works require attention; therefore at fuch times when the labourers have not full employment in the garden, the preparing of compofts for the pots and borders thould not be neglected, as thefe Should have time to lie and fweeten before they are ufed: for without this, there can be fmall hopes of having choice flowers in any tolerable degree of perfection.

Your choice Carnations and Auriculas fhould be guarded from heavy rains, fnow, and fevere froft, which are often very deftructive to them; but they fhould have as much free air as poffible in mild weather, otherwife they will draw up weak, and will not blow ftrong. At tisis feafon you muft alfo be careful to protect them from vermin, which, for want of other food, will deftroy them; particularly rats and mice often make great havock 


\section{Jan. The Gardeners Kalendar.}

havock with them; and where hares or rabbets can come to Carnations, they generally make clear work, feldom leaving any in their reach. The fparrows alfo, at this feafon, often peck out the heart or inner leaves of thefe plants, if they are not prevented.

At the latter end of this month you muft provide fome new dung, which thould be thrown on an heap to warm for about ten or twelve days, and turned over two or three times, "to mix the parts well together, in the fame way as is practifed for Cucumber beds, to make fome hot-beds to fow the choiceft forts of annual flowers upon, as the Amaranthus Tricolor, Cockfcomb, Globe Amaranthus, Diamond Ficoides, double Stramonium, fome of the forts of the annual Ketmia, Melongena, and other tender kinds of annual plants that they may be brought forward to flower; for the plants which are raifed early will be ftronger, than thofe which are fown later in the feafon; and by this method you may expect to obtai:! good feeds from all the forts, whereas many of them will not produce any in this climate, when they are not brought forward in the fpring.

Prune up wildernefs trees, and flowering mrubs where they grow too much out of Shape, 
26 The Gardeners Kalendar. Jan. Bhape, but their thoots mult not be fhortened, for that will prevent their flowering, and dig up the ground in wilkernefs quarters, obierving to clear it from the roots of all hurtful weeds. This digging will be of great fervice to the trees, and add a neatnefs to the wildernefs. But in doing of this, you mutt be careful not to diffurb the roots of thofe wood piants which are intermixed under the trees for the fake of their flowers.

You may yet fow the feeds of Auriculas and Polyanthufes, in mild weather, if it was neglected in Oetober and November, and where the pots or tubs in which the feeds are fown, are guarded from too much wet, the plants will often come up in good time. But if they thould not come up the firt fpring, the earth thould not be difturbed, for fometimes the plants will come up in autumn or the following fpring, provided the feeds are not buried too deep in the ground.

Plants now in Flower in the open Air.

Winter Aconite, Helleborafter or Bearsfoot, Green flowered Black Hellebore; True Black Hellebore or Chriftmas Rofe, fome fingle Anemonies in warm fituations, Blue and 


\section{Jan. The Gardeners Kalendar.}

and White Winter Hyacinths, Early Starry Hyacinth or Seilla Bifolia, Polyanthufes, Primrofes, Single Snowdrops, Round-leaved Spring Cyclamen, Hearts-eafe, or Panfies, Yellow Alpine Alyffon, Cyprefs Narciflus with many double flowers on each ftalk, Periwinkles, and, fometimes in a warm fituation, the Duke van Tol Tulip.

Fiardy Trees and Sbrubs now in Flower.

Lauruftinus two forts, Glaftenbury Thorn, Mezereon, Spurge-laurel, Strawberry tree, Manna Afh, Cornelian Cherry, Clematis Bætica, Alaternufes, Box tree, Hamemelis or Wich Hazel, Phil!yrea, Shrubby Baccharis of Virginia, Pyracantha in fruit, St. Peter's-wort Ahrub in fruit, and fome others.

MEDICINAL PLANTS which may now be gatbered for Ufe.

White and Black Maiden-hair, Golden Maiden-hair, Smallage roots, Birthwort roots, Arum roots, Afarabacca, Swallowwort roots, Afparagus roots, Spleenwort, Mafterwort roots, Beet roots, Biftort rocts, Briony roots, Buglors soots, Dwarf Elder roots, Leffer Celandine, or

Pilewort 
28 The Gardeners Kalendar. Jan. Pilewort roots, Iris or Oris roots, Cyprefs Cones, Dragon roots, Elecampane root, Eryngo root, Dropwort roots, Maie and Female Fern roots, Fennel roots, Greater Gentian roots, Liquorice roots, Ivy berries, Monks Rhubarb roots, Alifander roots, Dock roots, Henbane roots, Mandrake roots, Spignel roots, Piony roots, Butterbur roots, Parley roots, Hogs Fennel roots, Valerian roots, Meadow Saxifrage roots, Pinetree Cones, Solomon's Seal roots, Madder roots, Orchis or Satyrion roots, White Saxifrage roots, Skirret roots, Tarmentil roots. All thefe roots are much better for ufe, when they are taken up before they begin to fhoot; for after they have thot out new fibres, they either grow hard or Aticky, or foon Mrink when taken up, and lofe all their virtue.

\section{Work to be done in the NURSERY.}

If this month hould prove to be hard froft, you muft carry on dung upon the ground where you intend to tranfplant young trees or ftocks in the fpring; you may alfu lay fome dung between the rows of young trees where it is wanted, that it may be ready to be dug into the ground when the Froft is gone out of it. You may now trim and plan hedges, but it 


\section{Jan. The Gardeners Kalendar.}

is better to delay it until the froft is over, becaufe where trees are greatly wounded, the froft often penetrates, and much injures them; and when the hoots are frozen, they will not bend, but are apt to crack.

When the weather is mild, you thould continue trenching the ground, where you intend to plant young trees in the two following months; and prepare fome beds for fowing kernels of fruit trees, or maft and berries of foreft trees, or flowering Mrubs, fome of which muft be fown the latter end of this month, or the beginning of the next. You Mould alfo continue digging the ground between the rows of trees in the nurfery, when the weather is favourable, being careful not to injure their roots; but you hould horten all fuch roots as extend too far from the trees, which will caufe them to put out new fibres near the ftems, and thereby render them much fafer to tranfplant : this hould be particularly practifed to all the forts of ever-green trees, otherwife they will be unfafe to remove in a few years.

In frofty weather you hould carefully look to your young trees in the nurfery to prevent their being eaten by hares, rabbets, or other animals, which, in fevere feafons, often eat down young trees, and alfo difbark large trees and Mrrubs. 


\section{The Gardeners Kalendar. Jan.}

In open weather you may trim up your hardy foreft trees in the nurfery, but be careful to leave fome fmall thoots on the ftems of all young trees, to detain the fap for the augmentation of their Atems, otherwife they will bo too weak to fupport their heads; but thefe thould not be left in too great quantity, left you prevent the upright growth of the trees.

You may; towards the latter end of this month (if the weather is mild), tranfplant focks for fruit trees; as alfo young foreft trees, where it was neglected to be done, in the autumn; for the fooner it is done, it will be the better, provided the foil be dry; for when it is done late in the fpring, if it thould prove dry weather, they wili be in danger of being deftroyed, efpecially if there is not convenience to water them.

Work to be done in the GREEN-HOUSE and STOVE.

If this month proves very fevere (as it often happens), you mut be careful to keep the froit out of the green-houfe; for if it reaches the earth of your Orange-trees fo as to freeze it, it will caufe all the fruit to drop off, and many times a great part of the leaves alfo; 


\section{Jan. The Gardeners Kulendar. $3 \mathbf{r}$}

therefore it is very ufeful to have a flue contrived uncier the pavement, in the front of the green-houfe, which may be ufed in very hard winters, when it will be very difficult to keep the froft out of the houfe, where this is wanting; but where there is no fuch contrivance, the glaffes in front hould be clofely covered with mats, reeds, or ftraw; and you thould light fix or eight large candles to burn in the green-houfe every night; which are much better than burning of charcoal, as is by fome "practifed, which is equally pernicious to plants as animals, where the air is confined, as in green-houfes it murt be, when they are clofely fhut. Befides, in great thaws, when the air is filled with moifture, which occafions a great damp in green-houfes, it will be of great ufe to make two or three gentle fires where there are flues to rarefy and warm the air, which otherwife often occafions the leaves of the trees to grow mouldy, and drop off.

You muft alfo obferve to pick off all dead leaves, or fuch as are mouldy, which, if fuffered to remain on, would infect thofe which grow near them, and alio corrupt the air of the houfe, to the prejudice of your plants; befides, this adds a neatnefs to the houfe, and renders the plants more beautiful, as alfo more healthful. 


\section{The Gardeners Kalendar. Jan.}

healthful. In mild weather you muft let air into the houfe, without which the plants will alter their colour, and fometimes caft their leaves; but this muft be done cautiounly at this feafon. You muft alfo refren them with water as often as you find it neceffary, but give it to them fparingly; for it is better to give it them often, and in fmall quantities, than to over water them at this time of the year; becaufe it may prove very hurtful to them, efpecially if bad weather thould fet in foon after, and no fun appear in the day time to dry the damp, as is often the cafe at this feafon, when there are hard frofts; at which times there may be a neceffity to keep the houre clofely thut up for feveral days; fo that the moifture of the earth in the tubs and pot, will greatly add to the damp of the air.

The hardy fucculent plants muft have as much air as poffible in mild weather: for if they are too clofely fhut up, they often caft their leaves, and appear unfightly, efpecially the Sedums, Cotyledons, Cacalias, and Mefembrianthemi, which, when drawn too much, will not appear handfome, nor produce near fo many flowers, as thofe which are kept more hardy. 


\section{Jan. The Gardeners Kalendar.}

The Ananas, or Pine-apples, which begin now to thew their fruit, muft be carefully looked after, obferving to refres them when they are dry with water; for want of which, they are often farved, and the fruit is rendered fmall: but this water should be placed in the ftove at leaft twelve hours before it is ufed, that it may acquire an equal warmth with the air of the houfe, otherwife it will be too cold for them. You muft alfo keep up the warmth of the houfe, and not fuffer the heat to decline at this fealon, left thereby the fruit beftinted; the tan muit alfo be kept of a proper warmth, by firring of it up, if neceffary, and frefh tan put into the becis where it is wanting; for if the plants have not a proper heat to their roots, they will not produce large fruit : but, at the fame time, I mut caution againft the keeping the ftove too hot, which will force the fruit too much, and render it very finall; this alfo occations the young plants to hew fruit a year before their time, fo that their fruit will be exceeding fmall, and of little value.

The Coffee trees, and other woody plants which are placed in the bark-bed in the ftove, muft alfo be often refrefhed with water, and their dead or mouldy leaves conftantly taken off; and where any of the leaves have con- 


\section{The Gardeners Kalendar. Jan.}

tracted filth, it thould be carefully wanthed off; as thould infects, wherever the plants are infelted with them, otherwife they will increafe and ipread over all the plants in the houfe: this thould be performed with a wet fponge.

If the bark in the bed has fettled unequally (as it often happens) fo that the pots do not keep their pofition, it will be proper to take them out of the tan-bed in a fine day,and thir the bark, adding a little frem tan thereto (which hould have been in thelter a week or ten days before it is put into the bed to drain off the moifture) and then plunge the pots down again : this will renew the heat of the bed, and be very ufeful to the plants, but the plants muft not be expofed to the open ait while this is doing, at this feafon of the year.

The tender forts of Aloes, Cereufes, Euphorbias, and Melon thifles, hould now have very little water given to them; for moinure at this feafon is very injurious to them, efpecially where the air of the houfe is not kept in a due temperature of heat.

Plants in Flower in the GREEN-HOUSE and STOVE.

Double Nafurtium, Phylica, Solidago with a branching corymbus, Geranium with a fcarlet 
Jan. The Gardeners Kalendar.

flower, Indian Yellow, Spanin and Arabian Jafmines, African Gladiolus, Cacalia with fucculent leaves, Ofteofpermum with poplar Jeaves, Lantanas of two or three forts, Cefırum, Caffias, Hermannias, Papaya, Tarconanthus, Shrubby Baccharis with fawed leaves, Aloe Succotrina, Aloe Margaritifera major \& mincr, Curhion Aloe, Hedgehog Aloe, Partridge-breaft Aloe, Tongue Aloes of three or four forts, common Barbadoes Aloe, , fmall herbaceous Aloe, African Mountain Aloe, Cobweb Aloe, Arctotufes of two or three forts, Afcyron Balearicum, Canary Campanula, Mefembryanthemi of feveral forts, Sedum arborefcens, Craffulas, Malpighia mali Punici facie, Euphorbias, Bafella, the fmaller Leonurus, Perfian Cyclamens, Barbadoes Flower Fence, Hibifcus called China Rofe, fome forts of Apocynums, Crinum or Lily Afphodel, Pancratiums, African Grafs leaved Marygold, Black flowering Lotus, Diofina two forts, Shrubby African Mallow, Shrubby African Lavatera, Shrubby African Groundfel with Atiff leaves, Amaryllis, Myrtle of Ceylon, Ixia with white flowers, African Wood Sorrel, Amomum Plinii, with Oranges and Lemons in fruit.

$D 2 \quad F E-$ 


\section{$\left[3^{6}\right]$}

PQ) cons

\section{F E B R U A R $\mathrm{Y}$.}

Work to be done in the $\mathrm{K}$ I T C II ENG A R D E N.

sieroger $F$ the weather proves mild in this Q. 0 month, there is a great deal of bufinefs to be done in the kitchengarden, which, if omitted, will be of bad confequence, moft of the principal crops being now to be fown or planted; which, if deferred later in the year, feldom fucceed fo well, efpecially upon dry land. You muft now prepare your ground for Carrots, Parfneps, Radihes, Spinach, Beets, Beans, Peas, Parfley, and Cabbage Lettuce, which thould now be fown; and where it is only for the fupply of a family, there hould not be too much of each fort fown at one time; for it is a much better way to fow three or four times of each, (except the Parfley, Beet, and Parfneps) at about a fortnight or three 
Feb. The Gardeners Kalendar.

three weeks diftance from each other, that there may be a continuation of them for the kitchen, than to truft to one fowing, which will laft but a thort time; efpecially the Radifhes, Beans, Peas, and Lettuce; but if the other forts do fucceed, one fowing of each will be fufficient, unlefs where fmall young Carrots are wanted, as long in the feafon as they can be procured, and if Spinach is defired great part of the year, then the feeds mould be fown at different times, allowing a fortnight or three weeks interval between each fowing, according to the time of year; for in hot weather it will not continue long fit for ufe: but in moderate weather, and where there is proper allowance of room for growing, it will laft three weeks good.

Sow young Salleting upon moderate hotbeds, but in mild weather, the feeds may be fown on warm borders near walls, pales, or hedges, to fucceed that which was the laft fown; for at this feafon there fhould be a fupply forvn every week, which is as long as each fowing will continue fit for ufe, before it will be too large.

This is alfo the feafon for fowing Scorzonera, Salfafy, and Skirrets, for the firft crop; but the general crop muft be fown 


\section{$3^{8}$ The Gardeners Kalendar. Feb.}

much later; for if thefe are fown too early, they are very apt to run up to feed; but as in fome families thefe roots are required as long as they can be procured, they mut be fown at different feafons, that there may be fome roots for ufe early before the general crop comes in. You may now fow Cornfallet, large rooted Parfley, Winter Savory, Marigolds, and Sorrel, with moft other hardy plants; thefe are beft fown in feparate fpots or beds, and afterwards thinned to the proper diftance which each requires; for where they are fown with other crops, they do not thrive fo well; nor thould they be left too clofe, for then the plants will draw each other up weak, and becone frrall. But this is not to be underfood of the common or curled Parney, which is frequently fown in drills, for the more ready cutting of it, and keeping it clear from weeds, the curled fort is what I would recommend rather than the common Parlley, becaufe it is much eafier to be diftinguifhed from the lefier Hemlock, which is a poifonous herb; the large rooted Hamburgh Parfley thould be fown thin as Carrots, and hoed out in the fame manner as is practifed for them, that the roots may have room to 
Feb. The Gardeners Kalendar.

grow to a good fize, in which their goodnefs confifts.

Make moderate hot-beds for fowing fome Cauliflower feeds, for fummer plants to fupply the kitchen, after thofe which were fown in Auguft are gone; but the plants raifed at this feafon feldom fucceed well but in a moift foil, for in dry ground they rarely produce large heads. However, it is nccelfary to have them for a family, where the continuance of Cauliflowers are required, though they feldom pay the market Gardener.

Plant Garlic, Shallots, Rocambole, and Cives; as alfo Onions which have fprouted in winter to draw up for Scallions in April, when the dry Onions will be almoft gone, and the Michaelmas Onions will be too fmall for many kitchen ufes.

If the laft month was fo fevere, that little work could be done in the garden, then there will be a neceffity for forwarding bufiners in this, provided the feafon is favourable: therefore now hould be planted out fome of the fugar-loaf and long-fided ('abbages, to fucceed thofe which were planted in November. You muft alfo tranfplant your Cauliflower plants out of the winter beds, to the places where they are to grow; towards the end of the month.

$$
\text { D } 4 \text {. }
$$




\section{The Gardeners Kalendar. Feb.}

If the feafon is forward, you may llip fome of your old Artichoke ftocks if the rhoots are forward enough, and plant out fome of the cleareft and moft promifing plants for a rnew plantation; for on dry foils thefe llips mould be planted early in the feafon, otherwife the heads will be fmall, and when the plants are late planted on dry ground, they frequeatly mifs bearing the fame year. Thefe young plants will produce fruit in alitumn, after thole on the old ftocks are gone. The particular directions for doing this are exhibited in the Gardeners Dictionary.

Continue to plant Beans, and fow Peas, every fortnight or three Weeks, that there may be no want of thefe things in the kitchen during the feafon: the Windfor Bean is by much the beft fort for planting at this feafon, being much preferable for the table to all the forts for eating except the fmall Mazagan Bean; which fome perfons prefer to all the other kinds, therefore they continue planting that fort during the whole feafon of Beans. Some of the larger forts of Peas thould now be fown, particularly the Spanilh Morotto, which is a plentiful bearing fort, and a good Pea for eating, and the Marrow-fat; thefe are for the common ufe of the family; but fome of the 
Feb. The Gardeners Kalendar.

Charlton Hotfpur Peas mould be fown for the principal table, becaufe they are by much the beft Pea to eat green.

This is a proper feafon for planting of $\mathrm{Li}-$ quorice. The ground where this is to be planted, fnould be trenched three or four fpits deep, that the roots may more eafily run down; for the goodnefs of Liquorice depends on the length of the roots. 'The gardeners, who cultivate this plant, commonly fow a crop of Onions on the ground the fame fpring when they plant the fets; and the keeping of the ground clean from weeds is done by hoeing the Onions, and thefe are little or no prejudice to the Liquorice the firft year of its planting, becaufe the Onions will be drawn off before the Liquorice fhoots are much advanced.

Make new hot-beds for Afparagus to fucceed thofe which were made the laft month; for otherwife there will be a want in the kitchen, one of thefe beds feldom continuing much longer than a fortnight to produce good buds: fo that in this month there Thould be two beds made about eighteen or twenty days diftance, that they may fucceed each other regularly.

The Cucumber and Melon plants, which were raifed the laft month, will now be fit to tranfplant; 
42 The Gardeners Kalendar. Feb. tranfplant; therefore there muft be new beds made for them, which thould be well wrought, and the Dung well mixed to continue its warmth : but the plants muft not be planted therein, until the violent heat of the bed is over, which feldom lafts above a weck, efpecially if the dung had been two or three times turned over before it was ufed. At this feafon you muft attend very clofely to your hot-beds, to admit frefh air to the plants as often as the weather will permit; but this muft be managed with great caution, if you would have them fuccoed; for a fmall neglect at this feafon will deftroy all your plants, and put you greatly backward. There muft alfo be fome feeds of Cucumbers now fown, to fucceed thofe which are firft planted, efpecially if the beds have not a fufficient depth of earth upon the dung, the want of this often occafions the plants to decay very foon: but when the earth is laid a foot or more deep, the plants will continue long healthy and fruitful; by this method a fmall number of plants will be fufficient to fupply a family; but as the very early plants feldom continue long in bearing, where a pioper depth of earth is wanting, it is neceffary to have a fucceffion of hot-beds te fupply the table. This Month is full early 


\section{Feb. The Gardeners Kalendar.}

early to fow Melons for the firft crop, though by many gardeners they are fown in the former; but thofe frequently mifcarry, or produce fuch fruit as are unfit for the table.

The Murhroom beds muft now be carefully guarded from great rains and fnow, which, if they are not well defended from, will chill the beds, and deftroy all the fpawn, fo that they will never recover it : therefore it is the furelt method to have one or two beds covered with frames, or made under a thed thatched over with ftraw, which will protect them from bad weather; fo that a good Quantity of Murhrooms may be obtained in the worft feafons, by this method.

Plant fome Kidney-beans upon a moderate hot-bed for an early crop; obferving, when the plants are come up to give them air, whenever the weather will permit; otherwife they will draw up weak, and not produce fruit. The beft fort for this purpofe, are the Dwarf White, or the Batterfea Bean, which never run much to halm, and are plentiful bearers; but it is now generally practifed in fuch places where there are hot-beds for the Ananas, to bave a row of pots placed on the walks behind the tan-bed in which Kidney Beans are planted, and when care is taken in their culture, a 
4. The Gardeners Kalendar. Feb. good crop may be procured thro' the wirter, but the beft forts for this purpofe are the Scarlet Flowering, and large Dutch White Beans; which are by much the fweeteft for the table, and the plants will continue bearing a long time, provided they have room to grow tall. But many people plant for this purpofe, the upright, or, as fome call them, the Tree Kidney-bean, whofe feeds are black and white; this fort is indeed a plentiful bearer, but is by no means fo gcol for the table as the other, the pods being foft, and of a rank tafe.

If the weather be favourable, toward the end of this month, you muft plant your Cos, Cilicia, and the other beft forts of Lettuces, from the beds or borders where they grew in the winte: in doing of this fome of thofe plants in the borders fhould be left to remain for cabbaging, becaufe they will come earlier than thofe which are removed. You hould alfo fow fome feeds of thefe forts upon a fpot of good ground, in a warm fituation, or on a moderate hot-bed, to come after the winter plants are gone.

The latter end of this month you may fow fome Cabbages and Savoys for winter ufe; but thefe are not defigned for the main crop, but 


\section{Feb. The Gardeners Kalendar.}

only for a few to come early in the autumn: and upon hot-beds, or warm borders, muft be fown fome finall Sallet herbs, as Letuce, Creffes, Muftard, Rape, Radifn, Turnep, Ecc. that there may be a conftant fupply of thefe young Sallet herbs for the table.

Sow fome Celery feedis either upon a moderate hot-bed or on a boruer of rich earth, in a warm fituation, to come up early; but there fhould be little fown at this fealon, becaufe it will foon pipe, and become fticky, when fit for ufe; fo that no more hould be planted out of this fowing, than can be ufed in a month or five weeks, which is as long as this early crop of Celery will continue fit for ufe; and you mould now fow Apparagus feed in a bed of good earth, to raife plants againft the pext year to make frefh plantations.

Tranfpiant Cabbages, Savoys, Leeks, Parineps, Carrots, and Beets, for feed, if it was not done the former month, obferving (as was there directed) to hang up the Cabbages and Savoys in a dry place for five or fix days, that the wet may drain out from between their leaves, which, if left in, would rot them. You may alfo plant fome Endive for feed, if is was omited before, and fonte of the ftrongert piants of Celery thould alfo be left for feed. 


\section{The Gardeners Kalendar. Feb.}

Plant Potatoes and Jerufalem Artichokes, toward the end of the month, if the weather is inclinable to be good, and the ground dry, otherwife it will be better to defer this work a month longer, obferving to plough or trench the ground deep, that the roots may be placed at leaft fix or eight inches below the furface, otherwife they will not fucceed fo well : thefe fhould have a loamy foil; and when the roots are placed in the trenches, there Thould be fome dung laid over them, efpecially in poor ground, otherwife the roots will not be large. This mutt be underftood for the Potatoe; for the Jerufalem Artichoke is fo very hardy, as to multiply too faft in any foil or fituation.

Dung and trench the ground well, where you intend to plant Afparagus, letting it remain in ridges until the feafon for planting, which will be the latter end of next month; but in doing of this, you hould be careful to make the bottom of each trench level, before you put in the dung, which mult alfo be laid level: otherwife when you come to make the diills for laying in the plants, the dung will be turned up in thofe places where it lies nallow.

The Caulifower plants which were placed under bell or hand glafies in October laft 


\section{Feb. The Gardeners Kalendar.}

mould, toward the end of this month, be parted, leaving only one of the Atrongeft plants under each glafs, if you intend to have large heads, but many people who are covetous leave two plants remaining to flower; but where this is practifed, they cannot be fo long covered with the glaffes as where one plant is left: fo that they cannot be protected from the frofts which often happen in March, when, if the glaffes are not over the plants every night, they will be in danger of fuffering; nor will the flowers come fo early, nor their heads be fo large; therefore it is bad management to leave two plants, when it is certain one early large Caulifower will be worth more than three fmall ones. But in parting of thefe plaits, there muft be great care taken not to difturb the routs of thofe plants which are left; and the holes made in taking out of the plants thould be filled up level, that the roots of the plants left, may not fuffer from the drying winds whicis ufual blow the next month. But when the plants which are left are grown fo large as to prefs againft the glaffes, you mould raife the earth up into a border about the ftems of the plants two feet and a half broad, and five or fix inches high, that the glaffes may be advanced fo as not to cruih the leaves of the

plants : 
48 The Gardeners Kalendar. Feb. plants : by doing of this, the glafies may be kept over the plants in bad weather, until the middle or end of March, which is often of great ufe to them when the feafon is bad, and hereby they will be brought earlier to flower. When this is done, great care mutt be had that the earth doth not get into the heart of the plants, which will greatly injure, if rít defroy them.

The Peas and Beans, which were fown in autumn, and have ftood through the winter, will now begin to advance; therefore the ground about them fhould be hoed, and the earth drawn up to their fems; which will ftrengthen them, and guard their fiems from the injury of frofts; but this thould be done in dry weather, when the furface of the ground is dry, for when that is wet, it may injure the tender ftems of the plants.

Toward the end of this month, you may fow fome Puilane feeds upon a moderate hotbed, which will be fit for ufe in April; tho' that is earlier than the generality of people care to eat it, however in fome families it is required fo foon.

Look well to fnails and other vermin, which may be deftroyed in the holes of walls, and behind the ftems of wall fruit trees, $§ c$. for if 
Feb. The Gardeners Kalendar.

they efcape till the next month they will get abroad, and make great havock in the kitchengarden. If your early fruit trees againft the walls begin to open their flowers, they muft be carefully covered with mats, reeds, or fome other coverings; otherwife they will be in danger of fuffering by frofts, or cold winds, which frequently happen at this feafon. But. where any of thefe coverings are ufed, it muft be done with great care, fo as not to bruife or rub off the buds or bloffoms, therefore reeds are the beft covers, becaufe they are not fo liable to beat againft the trees as mats and other loofe coverings, and they are alfo much eafier to remove at all times in mild weather, whereby the blofforms will not be made too tender, nor the fhoots of the trees draw weak, for this will be attended with worfe confequences than if they were expofed to the inclemency of the feafon.

You may now plant Hops, dig the ground and prune the roots of the old hop grounds, being careful not to injure the buds of the plants which now begin to fwell. 


\section{The Gardeners Kalendar. Feb.}

Products of the KI T C HEN-GARDEN.

- Cabbages, Savoys, Borecole, Broccoli, Carrots, Parfneps, Turneps, Red Beets, Skirrets, Scorzonera, Salfafy, Cardoons, Coleworts, Spinach, Potatoes, Jerufalem Artichokes, Onions, Leeks, Garliek, Rocambole, Shallots, Sage, Parfley, Sorrel, Sprouts from the ftems of Cabbages and Savoys; and, on the hot-beds, Mint, Tanfey, and Tarragon, where they were planted early in January; and, in fome warm borders, there are Radifhes which were fown in autumn: upon hot-beds, all forts of fmall Sallet herbs, as Lettuce, Creffes, Coriander, Turnep, Rape, and Muftard; Mufhrooms on the beds which have been carefully defended from the wet and froft; you have alfo Endive and Celery, for foups, as alfo Chervil, which is, by many perfons, greatly efteemed: and on the hot-beds, made in December, you have Afparagus, which, towards the middle of this month, when there begins to be more funthine to colour it, will be very good; you have alfo many forts of pot-herbs, and aromatic plants, as Winter Savory, Hyfop, Thyme, Lavender, Rofemary, Pot-marjoram, and Burnet; alfo the leaves of the Chard-beet. 


\section{Feb. The Gardeners Kalendar. 5 I}

Work to be done in the FRUIT-GARDEN.

You may now continue to prune fuch of your fruit trees as were not before pruned, either againt walls, efpaliers, or ftandards, obferving to prune the more hardy forts firft, and let the tender kinds alone till laft, when there will be lefs danger of their fuffering by cold. And where any trees are too luxuriant, they mould be the laft pruned; but thofe which are now pruned fhould not be nailed to the wall till the beginning of next month, for the branches ftanding from the wall will keep their flower buds from opening too foun.

The Fig trees, which were covered in frofty weather to protect their tender branches from injury, hould be opened in warm weather to admit frefh air ; otherwife the lhoots of the former year will be apt to grow mouldy, which would decay them, whereby the trees will be deprived of fruit the following feafon, but if the froft returns they muft be corered again, otherwife they will be in more danger of having their tender branches and the fruit deftroyed, than thofe which were never covered.

Whenever the frames of your efpaliers are decayed, and have not been repaired the 


\section{The Gardeners Kalendar. Feb.}

former months, it Mould be no longer deferred, becaufe the flower-buds of the fruit trees will now begin to fwell, and thereby be in danger of being rubbed off; therefore thefe frames Mould always be repaired when the trees are pruned, that their branches may be faftened thereto, to prevent their breaking by ftrong winds. And fuch of your trees as have been trained to the efpaliers already, muft now be pruned, if it is not before done, and faftened thereto regularly, at their proper diftances, that when their fhoots come out, with their lcaves, they may be at equal diftarces, fo as not to crofs each other, or occafion confufion.

Tranfplant all forts of fruit trees, where they are wanting, this being the mort proper feafon for moin land (in which it is not fo well to plant in autumn); but you muft obferve to work the ground well, and break the clods before planting, that the earth may the better join between every part of the roots. The heads of thefe trees thould alfo be left on until they begin to puth, when thofe which require heading muft be carefully cut down after the manner direeted in the GARDENERS DICTIONARY, under the article Planting.

The latter end of this month (if the feafon proves mild) you murt begin to graft Pears,

Plums, 


\section{Feb. The Gardeners Kalendar. 53}

Plums, Cherries, and other hardy kinds of fruit; being very careful that they are well clayed or covered with the compofition directed in the GardFNERS Dictionary, under the article Grafting, that the wind cannot enter to the graft, upon which chiefly depends your fuccefs. Where grafts of fruit trees are wanting, they hould be cut off the beginning of this month, and laid in the ground till they are ufed; for as their buds will now begin to fwell, if the feafon is mild ; fo if they are left any longer upon the trees, they will be fo forward as to be in danger of uniting with the ftocks.

You may now fow the kernels and ftones of hardy fruits for ftocks, to bud and graft the more generous kinds upon, obferving to cover them equally with sarth, that none may appear above-ground to entice the mice or other vermin to them, which often deftroy whole beds of feeds, if they are not prevented. It will alfo be proper to have fome traps for mice, placed on the beds, that if the vermin Mould approach, they may be taken before they attack the feeds.

In moift weather, clear your fruit trees from mofs (where they are infefted with it); which, at this feafon, may be eafily done with an iron 


\section{The Gardeners Kalendar. Feb.}

inftrument maped like an hoe, and hollowed in the middle to the fize of the branches, which are to be fcraped; fo that there hould be three fizes of thefe inftruments, which will be fufficient for all the different branches; and the mofs being tender at this time, may be eafily rubbed off.

Look carefully after bullfinches to deftroy them; for, at this feafon, they do great mifchief to all forts of fruit trees, by pecking off their blofiom buds; fo that where they are not molefted, they often deftroy all the fruit of a garden in two or three days.

The early fruit frame, or forcing frame, muft now be duly attended, to give air to the trees in fuch proportion as the warmth of the feafon may require; as alfo to keep up the heat, without which the bloffoms or tender fruit will drop off, and come to nothing.

You muft now look carefully to the Strawberries which are in hot-beds, obferving to let them have a large thare of air, as alfo to refren them with water; otherwife the bloffoms will drop off, and there will be very little fruit produced. You may alfo, in this month, make new plantations of Strawberries, Rafpberries, Goofeberries and Currants, if it was omitted in autumn, which is by far the bett feafon 
Feb. The Gardeners Kalendar.

for this work, efpecially on dry foils; for thofe plants which are removed in autumn, will have their roots fo well eftablinied in the ground, as to be in little danger of fuffering by drought in the fpring ; whereas thofe which are now planted, will require conftant waterings if the fpring proves dry, otherwife they will fail, nor will thefe produce fruit the fummer following.

F R U I T in prime, or yet lafing.

Pears; Winter Boncretien, Beffy de Caffoy, Citron d'Hyver, Winter Ruffelet, Bugi, or Bergamot de Pafque, Lord Cheyne's Green Pear, Portail, Double Fleur, Saint Lezin, Carmelite, Saint Martial ; and for baking, the Cadillack, Union, or Pickering, Englin Warden, and Black Pear of Worcefter.

Apples; Aromatick Pippin, Golden Ruffet, Nonpareil, Golden Pippin, Holland Pippin, French Pippin, Kentih Pippin, Stone Pippin, John Apple, Harvey Apple, Pile's Ruffet, Wheeler's Ruffet, Winter Pearmain, Pomme d'Api, Haute Bonne, with fome others of lefs note. 
56 The Gardeners Kalendar. Feb.

Work to be done in the PLEASURE-GARDEN.

If the weather is mild, toward the end of the month you may plant out your choice Carnations into the pots where they are to remain to flower; in doing of which, you thould not take too much of the earth from their roots; and, when they are planted, it will be proper to place the pots in a warm fituation (but not too near walls and pales, which will draw them up weak); and arch them over with hoops, that in bad weather they may be covered with mats; for unlefs they acquire ftrength in the fpring, before the heat comes on, they will not produce large flowers.

You may yet fow Auricula and Polyanthus feeds in tubs or pots of light rich earth, placeing them where they may have the morning fun only until April, when they muft be removed into a more fady fituation, there to remain during the fummer feafon. Thefe feeds thould be very nightly covered with light earth; for if they are buried too deep, they often lie a year before they come up, and frequently mifcarry; therefore fome perfons never cover the feeds, but leave them to be wahed into the ground by the rain. 


\section{Feb. The Gardeners Kalendar.}

If your Auriculas in pots were not freth earthed the laft month, that hould be no longer deferred, the manner of doing this is directed in January; for now their flowerbuds will begin to hew apace, fo that if it be not done in a fhort time, their flowers will not be improved by it; and, in frofty weather, thefe flowers muft be covered with mats efpecially every night to prevent their tender flower-buds from being injured, otherwife many of the flower-buds will be killed, fo that the trufes will be thin of flowers.

Toward the end of the month, if the feafon proves favourable, Atir the furface of the ground of your flower-beds, and clear them from weeds, mofs, and whatever filth may appear thereon; which will be very ferviceable to the flowers, and add a neatnefs to the garden.

Dig and prepare your ground in the flowernurfery for fowing of feeds, and to receive plants the next month, when you will have much bufinefs of different kinds to do; fo that if you do not get things in forwardnefs this month, you will be fo much hurried in the next, that many things muft be omitted, or but nlightly performed. Therefore it is a good method to dig the ground at all leifure times, laying it in trenches, which will be of 


\section{$5^{8}$ The Gardeners Kalendar. Feb.}

great fervice in fweetening and mellowing the ground, and then it will be always ready for fowing and planting.

Tranfplant Canterbury Bells, French Honeyfuckles, Daifes, Rofe Campions, Foxgloves, Pinks, Sweet-Williams, Perennial Catchfly, Double Ragged Robins, Bachelorsbuttons, Gentianellas, Hepaticas, Campanulas, Thrift, Scarlet Lychnis, Columbines, Starworts, Golden-rods, with many other fibrousrooted plants, into the borders of your pleafuregarden, where they are defigned to flower ; but this is better if performed in October, efpecially where the ground is dry, becaufe the plants will have taken root, and obtained ftrength, before the dry weather of the fpring comes on, fo will produce a greater quantity of flowers, and will not require watering in dry weather.

In dry frofty nights you muft cover your beds of choice Ranunculures, Anemonies, and Tulips, with mats, to protect them from the injury of the weather; otherwife they will be in danger of fpoiling, at leaft their flowers will not be fo fair, nor numerous; and many times the roots are deftroyed by frofts at this feafon. Where this is not practifed, the froft often pinches the buds of the forward Anemonies, fo as to deftroy the middle of the

flowers, 
Feb. The Gardeners Kalendar.

flowers, which the Gardeners call the thrum, whereby the fineft double flowers are rendered fingle, which is a very great difappointment ; and if the roots were purchafed, the perfons who fold them are often blamed for having cheated the purchafer, when it is entirely owing to the neglect of covering them. This often occafions the roots to run barren, fo as not to have any more flowers.

You may yet, where there is neceffity for it, tranfplant all forts of hardy flowering trees and fhrubs, as Lilacs, Laburnums, Bladder Senas, Scorpion Senas, Rofes, Honeyfuckles, Jafmines, $\mathcal{E}^{2}$. and mort forts of foreft trees, which may be tranfplanted with fafety, efpecially on moift land, or where there is conveniency to water them; but many of the evergreens, defigned for the fpring planting, fhould not be removed till the beginning of April, when they are juft ready to pufh out their buds, which is the fafeft feafon for tranfplanting them.

Plant Dutch Box for edgings to borders: but it is a better feafon in October, efpecially for dry ground, becaufe it will be firmly rooted before the drought of the fpring, which is often very deftruetive to fuch edgings as 
are late planted, efpecially if they are not duly watered.

Break up your gravel walks, and turn thein, where they begin to be moffy, and require turning to make them clean; but do not rake them until the middle of next month, where they are not wanted for ufe, by which time they will be well fettled.

The latter end of this month you hould rake and clean the quarters of your wildernefs, becaufe the flowers which are under the trees will now begin to blow; fo that there is a neceffity of making the place clean, that it may appear fightly. The edges of the grafs walks and lawns fhould be cut by a line, that they may be even; and the water-tables on the fides of the walks fhould be dug and raked, that they may be clear from weeds and mors.

Your grafs walks, lawns, $\Xi^{2} c$. muft now be duly rolled, when the ground is foft; for unlefs this is conftantly performed, the grafs will not be fine. Make hot-beds for your tender annual flowers, which require to be broughe forward early in the fpring, which otherwife are in danger of not ripening their faeds; as the Amaranthufes, Gomphrena, Double flowering Stramonium, Double-ftriped Balfamine, Zinnia, Annual Mefembrianthemum,

Momo:- 


\section{Feb. The Gardeners Kalendar. 61}

Momordica, tender kinds of Hibifcus, Ricisus, with fome others. You muft alfo plant fome Tuberofes on a hot-bed, to come early in the fummer, provided you did not do it the laft month. You may now fow the double Larkfpur on warm dry borders, and thefe earlyfown flowers will be ftronger and more double (if they fucceed) than thofe which are fown later. The feeds of China Starworts muft be now fown in a warm border of light earth, or upon a very moderate hot-bed, jut to bring up the plants; then they Mould have a large thare of air every day, that they may not be drawn up weak.

Plants now in Flower in the PLEASUREGAR DEN.

Winter Aconite, Helleborafter or Bearsfoot, True black Hellebore, Green-flowered Black Hellebore, Snowdrops, feveral forts of Spring Crocufes, Single Anemonies, Spring $\mathrm{Cy}-$ clamen, Great Snowdrop, Early White and Blue Hyacinths, Early ftarry Hyacinth with white and blue flowers, Perfian Iris, Hepaticas, fingle Wall-Flower, Early Tulips, Polianthufes, Fennel-leaved Perennial Adonis, Dwarf Vernal Navelwort, Polyanthus, Narciffus, Panfies or 
62 The Gardeners Kalendar. Feb. Heart's-eafe, Periwinkles, Yellow Alpine Alyffon, Eaftern Alyffon with purple flowers, Violets, Blue Mountain Saxifrage, Soldanella Alpina, Ecc. with fome others.

\section{Hardy Trees and Sbrubs now in Flower.}

Lauruftinus, two or three forts, Mezereon both Red and White, Spurge-laurel, Spanifn Travellers-joy, Cherry Plum, White flowered Almond, Cornelian Cherry, Hamemelis, Mannia Afh, Filberts, Hazel-nuts, Glaftenbury Thorn, Coriaria Myrtifolia, Blue-berried Upright Honeyfuckle, Box tree, Alaternus, Phillyrea, and fome others.

Medicinal Plants wobich may nowv be gatbered for UJe.

Silver Fir, Black, White, and Golden Maiden-hair, Chickweed, Arbor Vitæ, Affarabacca, Ground Ivy, Spurge-laurel, Cyprefs Cones, Afh-coloured Ground Liverwort, Tree Mofs, Cup Mofs, Rue-leaved Whitlow-grafs, Pine tree Cones. And, if the feafon proves late, moft of the roots which are mentioned in the former month, may yet be taken up for ufe. 
Feb. The Gardeners Kalendar. ufe. If the feafon is forward, you have Violet flowers, Colss-foot flowers, Water-creffes; and the Birch tree will be fit to tap for the juice.

Work to be done in the NURSERY.

You may now tranfplant moft forts of hardy foreft trees, and flowering thrubs, provided the feafon be favourable; otherwife it will be better to defer it a little later. If you did not take off the layers of Elms, Limes, and other bardy foreft trees or Ahrubs, in the autumn, if fhould now be done, planting them into the nurfery in rows three feet afunder, and eighteen inches diftance in the rows; where many of the foreft trees may ftand four or five years to obtain ftrength, in order for tranfplanting where they are to remain: but the flowering Shrubs hould not ftand longer in the nurfery than two or three; for the younger thefe are when they are planted where they are to remain, they will more certainly grow, and will make greater progrefs.

The ground where you intend to plant a nurfery of evergreens, hould now be carefully trenched, obferving to cleanfe it from the roots of all noxious weeds, particularly Couch-

$$
\text { grafs, }
$$


64 The Gardeners Kalendar. Feb. grafs, which, if left in the ground, will mix with the roots of the new-pianted trees, and prove very injurious to them, and will be very difficult to get out again.

Where the ground between the trees in the nurfery was not dug the former month, either occafioned by weather, or want of leifure, it thould now be done, obferving (as was before directed) not to injure the roots; but morten fuch as were extended far from their ftems, in order to force out young roots nearer, that they may be fitted for tranfplanting; this fhould be particularly obferved in Hollies, and many other forts of evergreens, which thould be conftantly dug round every year, cutting off all downiight roots, and fuch as extend themfelves far from the plants, which will occafion a great quantity of ftrong fibres to be fent forth near their ftems, and render them, much fafer to remove, becaufe thefe will maintain a ball of earth to their roots, when they are carefully taken up; the want of which renders it almoft impracticable to tranfplant fuch trees as have remained many years, without having been dug round, and their roots cut.

You muft now plant Cheftnuts, and fow the feeds, mant, or berries, of other hardy trees 


\section{Feb. The Gardeners Kalendar. $\quad 6_{5}$}

and fhrubs, being careful to cover them with earth; for if any of them are left expofed, it will entice mice, and other vermin, whereby your feeds may be eaten up, and your whole feminary deftroyed.

Toward the latter end of this month, if the fpring proves forward, and the weather is mild, you hould cut off the heads of your ftocks, which were budded with fruit the preceding fummer, at about four or five inches above the buds, always obferving to cut the ftock noping from the bud, that when the buds fhoot, they may not be injured by the flowing of the fap from the wounded part of the ftock.

If this month proves mild, toward the end of it you muft graft Cherries, Plums, Pears, Apples, and other hardy fruits; but if there are hard frots, and drying winds, it will be better to defer it a little later: for fuch weather is often very deftructive to grafts.

You may yet plant cuttings of Currants, Goofeberries, and other trees which will grow from cuttings, in fhady borders, obferving to clofe the earth well about them; and if the ground between them is covered with mofs or Mort litter, it will prevent the drying winds of March from penetrating the ground, which frequently kill thefe late planted cuttings, 
66 The Gardeners Kalendar. Feb. where this precaution is wanting. The autumn is however the beft feafon for this work, efpecially in dry land.

Make layers of all your hardy exotick trees, which you want to increafe in this month, after all hard frofts are over; for fome of thefe are too tender to be laid in autumn, the wet of the winter, fucceeded by froft, being very deftructive to many of thefe tender plants, when laid.

You may now increafe fome of the exotick trees and hrubs, which do not eafily propagate by layers and cuttings, by cutting off fome of their young ftrong roots, dividing them into lengths of about four or five inches, planting them into pors filled with light loamy earth, plunging the pots into a moderate hot-bed, covering them clofe with glaffes, which will caufe them to put out roots below, and fhoots above, fo that in one year they will make good plants; by this method many plants have been increafed, which are very difficult to propagate in the ufual ways.

Work to be done in the GREEN-HOUSE and STOVE.

If the weather proves mild, and the air foft, you hould begin to admit air into your greenhoufe, 


\section{Feb. The Gardeners Kalendar.}

houfe, by drawing the upper fahes down a little; but this muft be done with caution at firft; never opening the glaffes when the wind is Aharp, or if it blows againt the front of the green-houfe; for a fharp air, at this feafon, will do great damage to your plants, as they have been rendered tender by fanding in the green-houfe all the winter. Myrtles, Oranges, Geraniums, and other hardy plants, muft now be frequently refrefhed with water; but let them have it moderately and often; for if it be given to them in large quantities at this feafon, it will be very injurious to them.

Pick off all dead and decayed leaves from your plants, and ftir the furface of the earth in the pots or tubs, clearing them from weeds; and if you add a little very rotten neats dung upon the tops of the tubs or pots of Orangetrees, it will be ferviceable to the plants. You mould at the fame time bruh down all cobwebs, and make the houfe clean in every part, neatnefs being as neceffary to the health of plants as of animals.

Make hot-beds to fow tender exotick feeds upon, which are brought from very hot countries, obferving to work the dung well, turning it over two or three times while it remains in the heap, and when removed to the beds, 


\section{The Gardeners Kalendar. Feb.}

it hould be well mixed, that the beds may retain their heat, and fettle equally; for when the dung is not equally ftirred, and beat down with a fork, it will fettle in holes, which is a great fault in thefe beds; becaufe when the beds are watered, the water will run into the holes and caufe thofe places to be over wet, when the other parts of the bed will receive little or no benefit from it; but the feeds of trees and thrubs will fucceed much better if they are fown in pots of eartb, and plunged into a hot-bed of tanners bark, becaufe as thefe feeds often remain a long time before they vegetate, and frequently lie in the ground a whole year, fo if the heat of the bed mould decline too much, it may be increafed again by ftirring it up, and adding fome new tas to it.

If any of the Orange trees have fuffered by ill management, fo much that their heads are decayed, you fbould now prune them clofe, and thift them into frem earth; and then prepare a moderate hot-bed in a glafs cafe, into which they mut be placed to force them out early in the fpring, that their moots may be placed abroad fo as to have time to harden before winter. But when they are taken out of the pots or tubs, you thould be careful to cut off all mouldy and decayed roots, and to cleanfe 
Feb. The Gardeners Kalendar.

both roots and ftems from any filth they may have contracted; and when planted again twift fome hay-bands round the ftems, from the furface of the ground up to their heads, which will prevent the fun from drying of their bark; when the pots or tubs are placed on the hotbed, you murt be careful that the heat be not too great, as alfo to frequently refreh them with water, not only giving it to their roots, but over every part of their items, whic will fupple their bark, and caufe them to purh cut vigoroufly. But when the fun begins to thine with great force, the glaffes of the houle hould be fhaded with mats or cloths, during the heat of the day, otherwife it will fcorch their tender leaves, and alfo dry the bark of the hoots; fo that they will greatly fuffer, if too much expofed thereto; but this heading and forcing of Orange trees thould not be to often practifed on them; for it will weaken the trees, when repeated too frequently; therefore where they are not in a very bad condition, it will be the better way to fhift them, if there be oscafion; and their ftems muft be well rubbed with a ftrong hair-bruth, with fcowering. fand and water; and cut off all decayed branches, and place them upon a gentle hot-bed for two or three months, after which in a Mady fitua-

$$
\text { F } 3
$$

riog, 


\section{The Gardeners Kalendar. Feb.}

tion, when they are brought out of the forcing frame, by this method they will break out again very ftrong and well. The Orange ftems alfo which are annually imported from Italy, fhould be treated in this way, to force out new thoots from them; but the roots of thefe thould be foaked in water two days before they are planted, and all the decayed and bruifed roots Thould be entirely cut off, their ftems carefully wahed, and cleanfed from filth, and the bed into which they are plunged, muft be of a moderate temperature for heat.

The $\tan$ in the beds of the ftoves will now require to be ftirred up, and fome freth bark added to them to renew their heat, which will now begin to decline, and if not timely renewed, the plants will fuffer greatly: but this muft be done in a warm day, when the air is foft; for in very cold weather the glaffes mut not be opened, fo that the bark could not be then put in without injuring the plants. At the fame time, fuch of the plants as are rooted through the pots, mould be hifted into pots a fize larger; but in doing of this, great care muft be had, not to injure their roots, becaufe at this feafon, they will not foon recover fuch a check. 
Feb. The Gardeners Kalendar.

Wan and clean the leaves of the Coffee trees, and other woody plants in the barkftove, to cleanfe them from infects and filth: and pick off all decayed leaves, which if left on, would infect the air of the houfe. The furface of the earth in the pots hould alfo be frequently ftirred, to prevent its binding, and Thould always be kept free from weeds.

The Anana plants will now thew their fruit apace, fo that they thould be frequently watered, giving them but little each time, to bring them forward and keep the fruit fwelling; and the tan mut be kept in a moderate temperature of warmth; for if that is fuffered to decline at this feafon, the plants will change their colour, and the fruit will be rendered fmall, and worth little. Toward the end of this month you muft prepare fome frefh bark to make the fummer beds for the Ananas, into which they fhould be plunged fome time the next month. But this is to be only underftood of thofe plants which are for a fucceffion, and the fuckers of the laft feafon; nor hould thefe be removed too early into the beds, unlefs there is a fire-place to warm the air in bad weather; for the warmth of the bark alone will not be fufficient for thefe plants, before the beginning of April, when the fun will have

$$
\text { F } 4
$$

power 
72 The Gardeners Kalendar. Feb. power to raife a warmth in the beds, which the tan alone would not do ; the beds in which the fruiting plants are placed, muft be refrefhed with fome new tan the latter end of this month, efpecially thofe beds whofe heat declines: for if the tan is not kept to a proper degree of warmth at this feafon, the growth of the fruit will be greatly retarded.

The Aloes, Euphorbiums, Torch-thifles, Melon-thiftes, and other tender fucculent plants, hould have very little water given them at this feafon; but the Ficoides, Sedums, Cotyledons, and other hardier kinds, murt be frequently refrehed; tho' they hould not have it in too large quantities, becaufe much wet at this feafon often rots them. You mutt now make freen hot-beds of tan, to fow the feeds of fuch tender exoticks as are annual, or that you may have received from abroad; into which you hould plunge fmall pots, filled with light frefh earth, that the mould may be warm before the feeds are fown. This method of fowing the feeds in pots is preferable to any other, becaufe the plants may be thaken out of the pots, when they are fit to tranfplant, with the earth about their roots, whereby they will be in little dan- 
Feb. The Gardeners Kalendar. $\quad 73$ ger of fuffering, becaufe their roots will be preferved entire. And fuch of the feeds as remain long in the ground, may be removed into a frefh hot-bed, when the heat of the firt declines, which will forward their vegetation.

Toward the end of this month, there fhould be fome hot dung prepared, to make a bed for to tranfplant fome of the tender forts of annual flowers, in order to bring them forward, that they may flower and perfeet their feed before winter.

Plants in Flower in the GREEN-HOUSE and STOVE.

Indian Yellow Jafmine, Ilex-leaved Jafmine or Lantana, Spanifh Jafmine, Heathleaved Phylica, Clutia with feffil leaves, Geranium with a fcarlet flower, Geranium with a variegated flower, feveral forts of Ficoides, Polygala Arborefcens, Aleppo Cyclamens, African Shrubby Cacalia with fucculent leaves, Shrubby Senecio with Buckfhorn leaves, Hermannia Alni folio, Aloes of feveral forts, Arctotufes, Turnera, Shrubby American Baftard Sena with a large yellow flower, Euphorbiums, Cotyledon with broad cut leaves, Malpighia mali punici facie, Purple-flowered Ragwort, 
74 The Gardeners Kalendar. Feb.

Ragwort, Ciftufes, Coffee tree, Ethiopian Calla, Hypericum Balearicum, Jacobæa Lily, Mexican Lily, Ixias, Watfonia, African Wood Sorrel with large purple flowers, African Wood Sorrel with umbellated yellow flowers, Shrubby purple Starwort from the Cape of Good Hope, Spreading Starwort with purple flowers from Africa, Sifyrinchium, Crinum, Pancratiums, Corona Regalis with roundifh leaves, Indian Gladiolus, Indian Birthwort with a fcarlet flower, African Tanfey, Coral tree, Antholiza, Tree Houfleek, Shrubby Lionftail, African Bermudiana, with fome others.

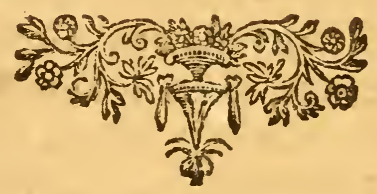




\section{[ 75]}

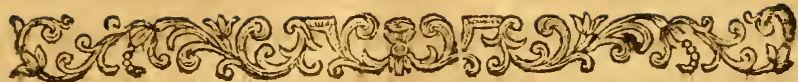

$\begin{array}{lllll}M & \mathrm{~A} & \mathrm{R} & \mathrm{C} & \mathrm{H}\end{array}$

Work to be done in the KITCHENGARDEN.

50 $\mathrm{HE}$ weather in this month is ge(2) Er nerally more unfettled than in any (3) (f) other month of the year: fome(6) times it proves dry and frofty; at other times cold and wet, with ftorms of hail, and ftrong winds; which makes a diligent attendance upon the hot-beds of Cucumbers and Melons abfolutely neceffary; otherwife they often mifcarry, or, at leant, lofe all their firft crop of fruit: to avoid which, if your beds have very much declined their heat, you hould add a lining of new horfe dung round the fides, which will renew the heat of the beds; and alfo obferve to cover the glaffes clofe with mats every night; but in the day time they muft have frefh air, in proportion to the heat of the beds, whenever the weather will permit, efpe- 
76 The Gardeners Kalendar. Mar. cially after the new dung is laid on their fides, which will often occafion a great fteam in the beds for fome days; which, if pent in the frames, will be very injurious to the plants, and frequently caufe the fruit to drop off.

Sow the feeds of Cabbages, Savoys, and Red Cabbages, for next winter's ufe, on a bed of light earth in the open air, and plant out all your Cauliflower plants which are remaining in the winter beds, into the quarters of the kitchen-garden, for the general crop; and thofe Cauliffower plants which were raifed the laft month, to fucceed thofe raifed in autumn, fhould now be pricked out upon fre $h$ hot-beds, to bring them forward; but they fhould not be too clofely covered, becaufe it will draw them up weak, and greatly injure them; therefore at all times when the weather is mild, the covers fhould be taken off, to let them enjoy the open air, and only covered in the night or bad weather.

Continue to put in Beans and Peas every fortnight or three weeks, that there may be a fuccefition of them through the feafon: and fow Radihes, Spinach, and young fallet herbs, every week, to fucceed thofe before fown ; and fow fome Celery feed towares the end of this 
Mar. The Gardeners Kalendar. month, to fucceed that which was fown in February.

You may now fow Parfneps, Carrots, Onions, Leeks, Beets, Borage, Buglors, Burnet, Dill, Fennel, Chervil, Smallage, Alifanders, Ecc. but thefe mould be fown early in the month, efpecially if the foil is dry, otherwife they feldom grow large; but upon a moift foil, the middle or latter end of the month is time enough. But as the feeds of Dill, Fennel, Smallage, and Alifanders, do often mifcarry when they are fown at this feafon, fo in dry land they will fucceed much better when they are fown in autumn.

The beginning of this month you hould earth up Alexanders to blanch them, which will render them very tender, fo that in three weeks time they will be fit for ufe; for when they begin to thoot their ftems for flowering, they are good for nothing. This is alfo the time for blanching Dandelion, which fume people are very fond to eat as a fallet herb: the plants may be procured from the fields, and planted deep into the ground, in the fame manner as is practifed for Endive, which will blanch it in three weeks fit for ufe.

You may, yet fow Parfley, Sorrel, Chervil, Orach, Marigolds, and Spinach, efpecially 


\section{The Gardeners Kalendar. Mar.}

cially if the ground is moift for in fuch land this feafon is better than to fow them earlier.

Slip and plant Tanfey, Pennyroyal, Chamomile, Baum, Savory, Sage, Rofemary, Hyffop, Lavender Cotton, Spike-lavender, Southernwood, Thyme, and moft other aromatick plants, which are now beginning to fhoot, and will take root better than at any other time of the year. And divide the roots of Mint, Tarragon, Wormwood, and other plants which annually die to their roots, and plant them in frem beds, that the old beds may be deftroyed in the fummer, when thefe are fit for ufe.

You may now llip the off-fets from the old roots of Skirrets, and plant them in rows ten inches afunder, and fix inches diftance in the rows, obferving, in dry weather, to water them until they have taken rcot; but thefe feldom make fo good roots as thofe raifed from feed.

Your Lettuce plants which have ftood the winter in warm borders, muft now be planted out into a more open expofure; otherwife they will draw up weak, and come to little, efpecially if they are near to walls, pales, or hedges, or where they are planted but a fmall diftance from each other : in which cafes a good part of the plants may be tranfplanted, and a few be left remaining at a proper diftance to furnih 


\section{Mar. The Gardeners Kalendar.}

the table early in the feafon. You muft alfo fow fome feeds of the Cicilia, Cos, Imperial, and other Lettuces, in an open rich fpot of ground, to fucceed thofe of the laft month's fowing.

About the middle of this month you muft fork the Afparagus beds in the full ground, being very careful not to burt the crown of the roots with the fork; but you may defer raking them fmooth till the beginning of next month, whereby you will retard the growth of weeds: and that will be early enough, provided it be done before the buds appear aboveground; for the only danger, attending this late dreffing, is the deftroying of the buds.

About the beginning of this month is a good feafon for fowing of the large-rooted Dutch Parfley; which may be fown either in open beds or in drills about a foot afunder; and, when the plants are come up, they fhould be thined fo as to leave them three or four inches apart in the rows, in order to obtain good roots: or they may be fown thin on a fpot of light earth, in the fame manner as Carrots, and hoed out; and managed as is ufually practifed for them, which is the fureft way to obtain large roots.

Toward the latter end of this month you may plant new Afparagus beds, if the ground 
be dry; but if it be wet, it will be better to defer it till the beginning of next month; for thefe plants always take beft, when they are tranfplanted juft as they begin to hoot. But in this you muft be determined by the feafon, either early or late, as it may happen.

Your Radifhes and Spinach, which were fown in January, and the beginning of February, thould now be hoed, leaving them four or five inches afunder; and obferve to ftir all the ground between them, which will deftroy all the young weeds, and greatly promote the growth of the plants; but this work thould be done in dry weather.

Continue to make hot-beds for Cucumbers, Melons, Purflane, Eंc. to fucceed thofe which were made the former month; and the end of the month fow Cucumber and Melon feeds, to ridge out under bell or hand glaffes, for the principal crop. And now the feeds of Capficum for pickling thould be fown, as alfo the Tomatos for foups, upon a hot-bed; and toward the end of the month, a few feeds of Indian Crefs hould be fown upon a very moderate hot-bed, to bring a few plants forward, where their flowers are wanted earlier than thofe ufually come which are fown in the open air. 
Mar. The Gardeners Kalendar. 8I

Drefs your Artichokes, obferving to leave only two or three of the cleareft and beft fituated plants upon each root to bear, and flip the reft clean off; the beft of which may be now planted to make a new plantation; for thefe will produce heads in autumn, after thofe upon the old roots are gone.

Sow Cardoons upon a bed of rich light earth, pretty thin, obferving to keep them clear from weeds; and, in dry weather, they muft be watered until they are big enough to tranfplant.

Toward the latter end of this month you may put in fome Kidney-beans in warm borders, where they may be defended from cold; but this muft not be done in wet weather, becaufe too much moiffure, at this feafon, will rot them in the ground.

You fhould alfo fow Sweet-marjoram, Thyme, Hyffop, and other tender aromatick plants, upon a dry warm foil; for they will not do well on a wet ground.

Continue to fow all forts of young fallet herbs, twice a week, as Creffes, Muftard, Rape, Radifh, $\mathcal{B}^{c}$. upon warm borders, until the latter end of the month, when they will do better in a more open expofure.

Part the roots of Cives and Efchalions, and plant them in a thady fituation to increafe them, 


\section{2

this being the right feafon for this work. Plant Rocambole and Shallots, and the beginning of the month tranfpant Leeks for feed; thefe Mould be planted near a reed hedge to a good expofure, becaufe the reeds do not ripen till late in the autumn, which in a bad feafon feldom ripen well, when they are in an open and cold fituation.

At the end of this month you may fow Purflane upon warm borders, in the common ground; where it will, at that time, do well without any artificial heat, provided the feafon proves warm and dry. You may alfo at this time fow Turneps upon an open fpot of ground, to come early.

You muft now fow the feeds of Finnochia in drills made about a foot afunder, into which the feeds thould be thinly fcattered, and covered over about half an inch thick with light earth. This mould have a rich light foil, otherwife it will not fucceed well.

Toward the end of this month you may fow Hemp, Flax, White Dutch, and Red Clover, Saitfoyn, and Lucern, provided the feafon proves favourable; otherwife it is better to defer it a little longer. This is the feafon for fowing of Barley and March Rye. In dry weather you may now hoe and roll Wheat. 
Mar. The Gardeners Kalendar. $\quad 83$

Sow all the forts of Rouncival and Grey Peas, for the full crop, in the open fields; and thofe Peas which were fown in the former months, and are come up, mould be gently earthed, and the ground hoed between them, in dry weather.

This month is the proper feafon for fowing of Carrots in the open fields; the roots of which are defigned for feeding of theep, deer, $\mathcal{E}^{2} c$. which is now much practifed by fome of the moft knowing farmers for theep; for one acre of Carrots will fatten more theep, than three acres of Turneps; and by fkilful gentlemen as a winter pabulum for deer and horfes, for as the Carrots are fown in the fpring, fo they are not liable to the accident of being deftroyed by the fly, as is the cafe of Turneps, which renders them a more certain crop.

\section{Products of the KITCHEN-GARDEN.}

Winter Spinach in great plenty, fome Cabbages and Savoys are yet remaining; Sprouts from the falks of Cabbages and Savoys in great plenty, and very good; Broccoli, Coleworts, Borecole, Red Beets, Chard Beets, Cardoons, Carrots, Parfneps, Turneps, Potatoes, Jerufalem 
84 The Gara'eners Kalendar. Mar. Aritchokes, Celery, Endive, and all forts of young fallet herbs; and, upon the hot-beds, Cucumbers, Afparagus, Peas, Kidney Beans, Purflane, \&ic. You have alfo, on warm borders, Mint, Tarragon, Tanfey, and Clary, with Sage, Parfley, Marigolds, Burnet, Sorrel, Hyffop, Winter Savory, Rofemary, Baum, and other kinds of pot herbs.

Work to he done in the FRUIT-GARDEN.

The beginning of this month you mutt finin pruning all the tender forts of fruit-trees, as Peaches, Apricots, Nectarines, E 3 c. for their buds, by this time, (if the fpring has been mild) will be very turgid, and in danger of being rubbed off, in nailing the branches. When you have finifhed the pruning and nailing of the trees, the ground thould be dug about their roots to loofen it, and deftroy the weeds. And when the trees are in bloffom, if the weather thould prove very harp, and the nights frofty, it will be proper to cover them with mats, canvas, or reeds, to guard them from the inclemency of weather, but thefe coverings hould be taken off at all times when the weather is mild, otherwife they will force out the fhoots too foon, and render the blof- 


\section{Mar. The Gardeners Kalendar. 85}

foms fo weak, that the leaft inclement weather will deftroy them; it will alfo be proper, in very dry feafons, to fprinkle fome water gent ly over the branches of fruit-trees, efpecially in mild weather; which will ftrengthen the blorfoms, forward the fruit, and alfo be of great fervice to the trees, but this muft be performed with great caution.

You may yet tranfplant fruit trees upon a moift foil; but if your ground be not ready before the middle of the month to receive them, it will be proper to take them up, and prune their roots, and then lay them in the ground, covering their roots and ftems with litter, to prevent their being dried by the fun and wind: this will retard their fhooting, and their roots will be prepared for puhing, by which method there will be little danger of their fucceeding; provided they are duly watered in dry weather, and the furface of the ground about their rocts covered with mulch, to prevent the fun and air from penetrating to the roots of the trees.

This is the principal month for grafting mont foris of fruit trees, beginning with the early kinds, that is, fuch as come firf out in blofiom, and ending with Apples, which are fome of the lateft in coming out ; but this mut

G 3 be 
be performed earlier or later, according to the feafon.

Cut off the heads of thofe ftocks which were inoculated the laft fummer, leaving about four inches above the bud to attract the fap, and, if need be, to faften the fhoot to, to prevent their being blown out of the ftock after they have made hoots and are covered with leaves; after this is done, the ground between the trees hould be dug to bury the weeds, aud loofen it, for the roots of the plants to find nourihment.

Drefs and frefh earth your beds of Strawberries, pulling off their ftrings, and clearing them from weeds, which will caufe them to produce a great quantity of fruit; and dig between the rows of Rafpberries (where it was not before done) to make the ground clean, and loofen it, that the roots of the plants may penetrate the better into it.

Your fruit trees which were planted the laft autumn, with their heads entire, hould now be headed down to three or four eyes; in doing of which, you muft be very careful not to diturb their roots: to prevent which, you fhould place your foot clofe to the ftem of the tree, and hold the lower part of the ftock faft with your left hand, while, with a harp knife 
Mar. The Gardeners Kalendar. 87 in your right hand, you cut off the head. You thould alfo cover the ground about the roots of new planted trees carefully with mulch, or rather with fome green fwards taken from a common or pafture, turning the grafs downward, which will prevent the fun and wind from penetrating the ground to the roots of the trees, the neglect of which has deftroyed many new-planted trees.

Thofe trees which were grafted the former fpring, and are yet remaining in the nurfery, fhould be fhortened to four or five eyes, that they may be furnifhed with lateral branches near the ground; othewife they will run up tall, and become naked at bottom; but this is chiefly to be underftood of dwarf trecs.

Dig and clear the ground between your Goofeberries and Currants, which will ftrengthen their bloffoms, encourage the trees, and add a neatnefs to the place.

Fruits in Prime, or yet lafting.

Pears; Bergamot Bugi, Saint Martial, Winter Boncretien, Double Fleur, Royal d'Hyver, Bezy de Chaumontelle, L'Amozelle; and, for baking, the Cadillac, Parkin- 


\section{The Gardeners Kalendar. Mar.}

fon's Warden, Union or Pickering, with fome others.

Apples; Loan's Pearmain, Nonpareil, Golden Ruffet, Pile's Ruffet, Wheeler's Ruffet, Kentin Pippin, Holland Pippin, French Pippin, Pomme d'Api, Store Pippin, John Apple, with fome others.

Work to be done in the F LOWER-GARDEN.

In this month you may tranfplant moft forts of fibrous-rooted plants; as Carnations, Pinks, Sweet Williams, Rofe Campions, Lychnifes, Thrift, Afters, Golden-rods, Perennial Sunflowers, Canterbury Bells, Peach-leaved Bell-flower, French Honeyfuckles, Daifies, Buphthalmums, Leucanthemums, Chryfanthemums, perennial Sunflowers, the hardy forts of Geranium, Speedwell, Columbines, Hieraciums, Hepaticas, Fraxinellas, Ragged Robin, Wholefome Woolfsbane, with many other forts; though if the foil be dry, it would have been better if done in the autumn, becaufe they wculd have taken root in the ground, and fo be better enabled to refin the drought, and alfo to produce a greater quantity of flowers.

Stir the earth of your borders, and beds of Alowers, which were planted in the autumn 


\section{Mar. The Gardeners Kalendar. $\quad 89$}

with a narrow trowel; being very careful, in doing of this, not to injure the roots, nor the flower buds, which now begin to appear; this will prevent the growth of weeds, and, when raked over fmooth, will render the beds more agreeable to the eye.

Your choice Hyacinths, Anemonies, Ranunculufes, and Tulips, will now begin to thew their flower buds, when they hould be carefully covered with mats or canvas in bad weather; for, at this feafon, the nights are often frofty, and if thefe flowers are expofed to the cold, their buds are frequently pinched, fo that they will not open fo fair as thofe which are protected. At this time, there fhould be fmall fticks put down by the roots of the fine Hyacinths, to which their ftems thould be faftened to fupport them; otherwife thofe with double flowers, being very heavy, will bear down the ftalks, and fpoil their beauty.

Plant fome roots of common double Anemonies to fower late, after thofe which were pianted in autumn are paft; and if the feafon fhould prove dry, refrefh them now and then with water, otherwife they will not fucceed well.

The boxes and pots with feedling Auriculas hould now be placed in a Mady fituation; for 


\section{9o The Gardeners Kalendar. Mar.}

the plants will begin to appear, and if they are expofed to the full fun but one day, while they are young, it will deftroy moft of them: you muft alfo refreth them with water in dry weather, but give it them very gently, left you wafh them out of the ground.

Your pots of choice Auriculas muft now be taken care of, to protect them from blighting winds and frofty nights, which will otherwife pinch their flower buds, and fpoil their blowing: you muit alfo refrefh them now and then with water in dry weather, but do not let the wet get into the center of the plants, left it injure the flower ftems.

Dig up the ground in your wildernefs quarters, and between flowering fhrubs, if it hath not been done the former month: this will loofen the ground, and encourage the hrubs to flower Atrongly, and render the place free from weeds; for neatnefs is always to be defired in every part of a garden: but in doing of this, there fhould be great care taken not to cut or injure the roots of fuch flowers as are planted between the trees and fhrubs.

Give frem earth to the Carnations which were planted out for good in the autumn, which mut be done by taking part of the earth out of the pots, being careful not to difrub their 


\section{Mar. The Gardeners Kalendar. 9 I}

their roots, and then fill up the pots with frefh earth, and pick off decayed leaves; this will greatly ftrengthen them for flowering.

Your pots of double Rofe Campions, Campanulas, Scarlet Lychnifes, Eंc. which were alfo planted in the autumn, hould have all dead leaves and filth carefully taken from them, and the earth on the top of the pots taken out, the pots refilled with freh rich earth, in which care mult be taken not to let the earth in between the leaves fo as to bury any part of them; where this is properly done, it will ftrengthen the plants greatly for flowering.

Clean the flower beds and borders of weeds, and gently fir the furface of the ground, to clear off Mors, Eंc. This will add a neatnefs, and be of great fervice to the flowers.

Towards the latter end of this month, you may fow the feeds of all hardy annual flowers in the borders of the pleafure-garden; fuch as Flos Adonis, Venus Look-glafs, Venus Navelwort, Sweet-fcented Peas, Tangier Peas, Lobel's Catchfy, Large Double Poppy, Dwarf Lychnis, Dwarf Annual Stock, Candy Tuft, Lavateras, Hibifcus Trionum of three forts, Convolvulus Minor, Convolvulus Major, Sweet Sultans, Annual Sunflower, Nafturtium Indicum, Divarf Poppy, Dracocephalum of feveral

forts, 


\section{The Gardeners Kalendar. Mar.}

forts, Hieraciums, Nigella, Sweet Scabious, Catterpillar plant, Snail plant, with many others. The beft method is to fow the feeds thin in little patches, where they are to remain; and where the plants come up too thick, they thould be thinned, leaving but few in each patch, according to the fize of their growth, for thefe forts do not fucceed fo well when they are tranfplanted.

You may now fow the feeds of many kinds of biennial and perennial plants in your flowernurfery, to fupply the borders of the flowergarden the following year; as Columbines, Canterbury Bells, French Honeyfuckles, Stockgilliflowers, Wall-flowers, Sweet Williams, Pinks, Tree Primrofe, Greek Valerian, Pyramidal Campanula, Single Scarlet Lychnis, Single Rofe Campion, Single Catchfly, Veronicas, Catananche with blue flowers, perennial Larkfpur, Gaura, Scrophularia, Garden Valerian, with fome others. Upon a moderate hot-bed you may now fow the feeds of Marvel of Peru, French Marigold, Female Balfamine, African Marigold, Convolvulus Major, Capficums, Stramoniums, Indian Pink, Sweet Sultan, Po-mum Amoris, or Love Apple, Tree Amaranthus, Purple Amaranthus, or Love-lies-ableeding, and many other forts, which are in- 


\section{Mar. The Gardeners Kalendar. 93}

different hardy, but require warmth to bring them forward in the fpring; yet if fown too early, are apt to grow too large before the feafon will be favourable enough to tranfplant them abroad.

Make frem hot-beds for your choice forts of annual plants, which were fown the former month, and let the earth upon thefe beds be very good, for otherwife your plants will not thrive well. When the heat of the bed is moderate, the plants Thould be placed into them, allowing them proper diftances to grow; and obferve to thade them in the day time from the fun, until they have taken new root, and to refrem them with water, as they Shall require; by which method your Amaranthufes, and other forts of curious annuals, may be brought to a large fize.

Toward the end of the month if the feafon be mild and inclinable to wet, you mav tranfplant mort forts of Evergreens, as Hollies, Yew's, Phillyreas, Alaternufes, Bays, Magnolias, Cyprefs, Cedar of Libanus, Evergreen Cafinne, Cifufes of all forts, Moontrefoil, American Junipers, Evergreen Oak, Cork Tree, Ec. with many other kinds of exotick trees, obferving to cover the furface of the ground with mulch after they are planted, to prevent 


\section{The Gardeners Kalendar. Mar.}

the fun and wind from penetrating the ground, and drying their roots; but if this month be cold, and north or eaft winds reign, with dry weather, it will be better to wait till the beginning of next month, when the feafon may be more favourable.

In this month the feeds of the Arbutus or Strawberry tree may be fown on a moderate hot-bed, which will greatly forward its growth, provided the bed is duly watered and haded from the fun in the heat of the day.

You may now fow the feeds of Firs, Pines, Bays, Cedars, Alaternufes, Phillyreas, and other evergreen or hardy exotick trees, in fuch places where they may be expofed only to the morning fun; obferving, if the place is wet, to raife the borders fo much above the level of the ground, as not to have any water remain near the furface, as alfo to cover the feeds with light earth; but if the feeds of moft of thefe forts of trees are fown upon a very moderate hot-bed, it will be a more fure method of raifing the plants, and it will greatly forward their growth. But there nuft be great care taken when the plants appear, to admit the free air to them at all times in favourable weather, otherwife they will draw up weak, and come to little. 


\section{Mar. The Gardeners Kalendar.}

Plants now in Flower in the PLEASUREGARDEN.

Crocufes of various forts, Double Snowdrop, large early Snowdrop, feveral forts of Narciffufes, Perfian Iris, Double Pilewort, Daffodils of feveral forts, Spring Cyclamen, Early Tulips, Crown Imperials, Hyacinths of feveral Sorts, Fennel-leaved Perennial Adonis, fome Anemonies, Violets, Hepaticas, Wallflowers, Alyffon, Perennial Fumitary, Primrofes, Polyanthufes, Daifies, Dogs-tooth Violet, Mufcari, Hollow-root, Hermodactyl, Spring Colchicum, Auriculas, Hearts-eafe or Panfies, Rofe-root, Wood Anemonies, Hellebores, Perennial Navelwort, Blue Mountain Saxifrage, Spanifh White Sedum, Venetian Vetch, Yellow Star Flower, Eaftern Lungwort, Borage of Conftantinople, with fome others.

Hardy Trees and Sbrubs now in Flower.

Almond trees, Cherry Plum, Mezereons, Spurge-laurel, Lauruftinus, Spanifh Travellers-joy, Siberian Clematis, Cornelian Cherry, Benjamin tree, Willow-leaved Sea Buckthorn, Upright Honeyfuckle, Scarlet flowering Maple, 


\section{The Gardeners Kalendar. Mar.}

ple, Norway Maple, Laurel or Cherry Bay, Larch tree, Manna Ah, Siberian Cytifus, with fome others.

MEDICINAL PLANTS wobich may now be gathered for Ufe.

Brooklime, Elder buds, Nettle tops, Coltsfoot flowers, Noble Liverwort, Primrofe, Violet, Rue-leaved Whitlow-grafs, Water-crefs, and, toward the end of the month, the Poplar buds.

\section{Work to be done in the NURSERY.}

In this month you Mould fow the feeds of Evergreens, fuch as Firs, Pines, Evergreen Oaks, Cedar of Libanus, Cyprefs, Juniper, Bays, and fome other forts; as alfo of feveral other hardy exotick trees, as the three thorned Acacia from Virginia, Perfimon, Liquid Amber, Virginia Walnuts, Hickery Nuts, Occidental and Oriental Plane trees, Saffafras, Vitginia Dogwood, Larch tree, Arbor Judæ, American Cyprefs, Black Haw, all the forts of Medlar, Lazaroles, Chinquapin, Tulip tree, Baftard Acacia, Piftachia nuts, and fome other forts, 


\section{Mar. The Gardeners Kalendar.}

the method of fowing each fort is fully inferted in the Gardeners Dictionary.

You may now tranfplant moft forts of evergreens and exotick trees, provided the feafon proves favourable; otherwife you had better defer it until the beginning of the next month, always obferving to do it when the wind is fouthwardly, and when there is a profpect of fome rain in a fhort time; for if it hould prove dry weather, and the wind eaftwardly, it would not be fafe to tranfplant them. This work Thould be deferred till toward the end of the month, for fear the Marpeaftwardly winds with frofty nights thould return after this is performed, which would endanger the plants.

This is the feafon for planting cuttings of feveral forts of exotick trees and Mrubs, which generally fucceed beft, when they are planted juft before they begin to hoot; but if the feafon hould prove dry, they muft be frequently watered, and the furface of the ground covered with mofs or mulch, to prevent the fun and air from penetrating deep into the ground, which is apt to deftroy fuch plants as are not well rooted.

Graft all forts of fruit trees in this month; and toward the latter end you may graft Hollies, and inarch any of the hardy exotick trees 
98 The Gardeners Kalendar. Mar. and thrubs; in the doing of which, you hould be careful to clay them well; for if the air or wet gets into the cleft part of the ftocks, it will prevent the grafts from uniting with them.

Continue to dig between your young trees, where it was not done in the former months, that your ground may be fitred, and made clean, before the trees begin to hoot, which will not only render the nurfery neat, but be of great fervice to the growth of the trees.

The end of this month you mould plant cuttings of vines, obferving to lay them in the ground to the uppermoll eye, fo that no part of the cutting may appear above ground. If this be duly obferved, and fuch cuttings only chofen which have a knot of the former year's wood at their bottom, there will be no danger of their rooting.

Stake and tie up fuch plants as you are defirous to have with Atrait ftems; for if you neglect this when the plants are young, it cannot be fo well performed after their ftems are grown large and woody.

At this feafon many of the trees and fhrubs, whofe feeds were fown in auturing of the former fpring, will begin to appear, therefore they fhould be carefully weeded; and if the feafon 


\section{Mar. The Gardeners Kalendar.}

Thould prove very dry, they fhould have a litthe water once a week, and be guarded again $\mathrm{ft}$ birds, mice, moles, hares, rabbets, and other vermin, which if expofed to, may in a thort time be entirely deftroyed. And if the nights hould prove frofty, all the beds in which the young feedling piants are come up thould be carefully covered, otherwife the froft will nip off the plants which are juft peeping out of the ground; or by loofening the earth, their roots will be turned out of the ground: at this time the Common and Swedin Juniper, Holly, Yew, Virginia and Carolina Cedars, American Dogwood, Saffafras, ard other hard feeded plants, which were fown the laft year, will begin to appear; therefore they hould be diligently looked after, to prevent their being injured by frofts, or harp eaftwardly winds. Such of thefe as were fown in pots, may be now placed on a moderate hot-bed, which will forward their coming up, and by being pufned a little in the fpring, the plants will get ftrong by the autumn, fo will be better able to ftand through the following winter. And fuch of thefe plants as came up the laft year, and require to be tranfplanted, fhould at this feafon be feparated and each planted in a fmall pot, placing them on a moderate hot-bed which if it is 


\section{$1 \odot 0$ The Gardeners Kalendar. Mar.}

arched over with hoops, and covered with mats will be fufficient for thofe hardier forts of plants, as the fpring will foon advance, and by this method they will be greatly forwarded in their growth.

Work to be done in the GREEN-HOUSE and STOVE.

Water your Orange trees, Myrtles, Bays, Amomum Plinii, and other lefs tender exotick trees, frequently, but do not give it to them too plentifully; and begin to inure them to the air by degrees, opening the glaffes whenever the air is foft and mild; but in cold days, or when the air is Tharp, it fhould not be too plentifully admitted to them; for by being made tender in the houfe, a little tharp air will be prejudicial to them, until they are become fomewhat hardier.

Wan and cleanfe the leaves and ftems of Orange trees from the filth which they have contracted, during their confinement in the houfe; and thofe which do not require to be Mifted, hould have the earth taken out from the upper part of the tubs or pots, filling them again wich fresh rich earth, which will ftreng- 


\section{Mar. The Gardeners Kalendar. I0I}

then them greatly, and prepare them for flowering.

Toward the end of this month (if the weather is favourable) you may take out your tubs of Bays, Lauruftinufes, Tree Wormwood, Ciftus, and other hardy kinds, placing them near an hedge, in a fituation where they may be well defended from cold winds; and this will thin the houfe of plants, and give room to thofe that remain, to have a greater hare of free air ; but this muft be underftood if the feafon is very mild, otherwife it muft be deferred till next month.

If any of your Orange trees have decayed heads they thould now be hifted, and their heads pruned clofe, and placed upon a hotbed of tanners bark, to force them out again; treating them in the manner directed in the former month.

You may alfo head down fuch Myrtles, Bays, and other of the hardy kinds of exoticks, as have ragged or decayed heads, obferving to place them on a very moderate hot-bed, juft to make them pufh again, but after they have made Thoots, they fhould have as much free air as poffible in warm weather, to harden the young branches. By this method you may renew their heads, which, with Ikilful pruning, may 


\section{The Gardeners Kalendar. Mar.}

be reduced into good order again, and the trees be rendered beautiful.

The beginning of this month, fow the kernels of Oranges, Lemons, and Citrons, for ftocks to bud the feveral kinds of thofe fruits upon; if there are taken from rotten fruits which had been fully ripe, they are better than thofe from found ones, provided the kernels are not decayed; thefe fhould be fown in pots, and plunged into moderate hot-beds of tanners bark, refrehing them often with water, which will bring them on prodigiouny; but, in very hot weather, the glaffes hould be covered with mats, during the heat of the day.

The reeds of Amomum Plinii, or Winter Cherry, may now be fown in pots, and plunged into a moderate hot-bed; and when the plants are come up three or four inches high, they may be tranfplanted into feparate pots, and put into another hot-bed: thefe plants may be brought fo forward, as to have plenty of fruit by the next winter, if they are fown the beginning of this month.

Make fome hot-beds of tanners bark, in order to tranfplant fuch tender exotick plants as are come up from the feeds fown the former month; and, when the beds are in due order, fome fmall pots thould be filled with frefh rich earth, and plunged into the bed, that the eartin 
Mar. The Gardeners Kalendar. $\quad 103$ may warm before the plants are placed therein; which fhould be done in a day or two after the pots are plunged, otherwife the earth will become too dry when the plants are planted; thefe murt be gently watered after they are planted, and the glaffes foaded until they have taken root; after which they frould be frequently refrefhed with water, and the air muit be let into the beds propurtionably to the warmth of the feafon.

The fires in the ftores fhould now be abated; but this muft be done with difcretion according as the weather increafes in warmth.

Thofe Ananas or Pine apples, which have been in a dry ftove during the winter feafon, Thould now be removed into bark-beds; therefore, if the beds were not prepared to receive them, it thould be no longer delayed than the beginning of this month, for the bloffoms of the fruit will now begin to appear; and if the plants are checked at that time, their fruit is feldom fo fair, nor fo early ripe; and thofe, piants which have been in tan all the winter, the beds thould now be refrehled with fome new tan to renew their heat.

Suir up the bark-beds in the ftove which are filled with tender exotick plants, adding fome fren $\tan$ to renew their heat; and clean the 


\section{The Gardeners Kalendar. Mar.}

leaves of the Coffee trees, and other woody plants, from the filth they may have contracted; picking off all decayed leaves, which, if fuffered to remain on, injure the plants, and occafion an unfightly appearance.

Plants in Flower in the G R E N-H O U S and $\mathrm{S}$ T O V E.

Mefembryanthemi of feveral forts, llex-leaved Lantana, Spanifh Jafmine, Hermania with Alder leaves, as alfo with Marfhmallow leaves, Arctotufes of two or three kinds, African Thrubby Polygala, Aleppo Cyclamens, Geraniums of feveral forts, Shrubby Senecio with fucculent leaves, Aloes of feveral forts, Coronilla Cretica, African tree Houfleek, Pancratium, Turnera, Cotyledon with a broad cut leaf, Cytifus hirfutus, Shrubby St. Johnfwort of Minorca. African Grafs leaved Marygold, Lycium with narrow leaves, Canaty Campanula, African Fleabane with a Sage leaf, Ciftufes of feveral forts, Caffia of two or three kinds, Medicago arborefcens, Crinums, Coffee tree, Jacobæa with purple flowers, Tithymals of feveral forts, Teucrium Bæticum, Phylica, Chryfocoma, Cytifus from the Canaries, Ornithogalums from the Cape of Good Hope of two or thee forts, three 
Mar. The Gardeners Kalendar. 105

three or four forts of Ixia, Cunonia, Watfonia, Antholyza, African Wood Sorrel with large purple flowers, and that fort with large yellow flowers, Tree Scabious, Shrubby:African Marigold, Othonna with cut leaves,'African Shrubby Tanfies, Shrubby Candy Tuft, Shrubby African Starwort, Indian Canna, Celaftrus, Malpighias, Smallcreeping Cereus with crimfon flowers, Purple Lotus, Euphorbiums, Tetragonia with trailing branches, Amaryllis of two or three forts, two forts of Jufticia, African Calla, Gladiolus from the Cape of Good Hope, African Bermudiana, Morea, Sifyrinchiums, Carolina Coral tree, with fome others. 


\section{$[106]$}

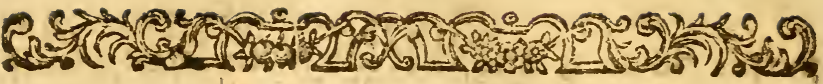

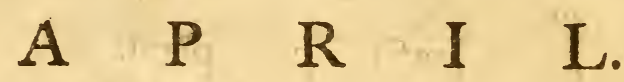

Work to be done in the KITCHENG A R D E N.

forges $\mathrm{N}$ the beginning of this month, 7. 7 you muft prepare your dung by 19. (1) Jan warm, fo as to be fit for ufe by the middle of the month; to make ridges for $\mathrm{Me}$ lons and Cucumbers, which are to be covered with bell or hand glaffes; and as this bufinefs may be continued to the end of the month, where large quantities are required, fo a fortnight after fome more dung thould be mixed in heaps for this purpofe: but thofe beds which are made late in the month need not have fo much dung in them as the early ones. The middle of this month is a proper time to plant out the Melons which are to be raifed under paper. In making of thefe ridges, 
Apr. The Gardeners Kalendar. $\quad 107$ if the ground is dry, the dung thould lie but half a foot higher than the furface of the ground; and the earth fhould be laid at leaft a foot and half thick upon the dung, that the Melon plants may have depth enough to root. Where this is practifed, the plants will require no water after they are well rooted; and hereby a good crop of the choicer forts of Melons may be always obtained; which, in the common method, generally mifcarry, or produce but few fruit ; but in wet land the ridges hould be raifed above the level of the ground, that the dung may not have fo much wet as to chill it, whereby the plants are often deftroyed, when this care is not taken. But the alleys between thefe beds thould be afterward raifed with dung and earth to the level of the beds, that the roots may have room to extend on each fide, for the roots of thefe plants fpread as far in the ground, as their branches extend on the furface.

You may ftill fow Sweet Marjoram, Thyme, Summer Savory, and other aromatick plants; the firft of which does not fucceed if it is fown too early, efpecially if the fpring is cold and wet.

Plant Kidney Beans the beginning of the month in a warm fituation, and in dry weather, 


\section{The Gardeners Kalendar. Apr.}

ther, for much wet will deftroy the feeds in the ground; you may now fow Purflane upon warm borders, to come after that on the hotbed is gone.

Continue to hoe your crops of Radilhes, Carrots, Parñeps, Onions, Leeks, $\mho^{3}$. thinning them out to proper diftances; and cut down all the weeds among them : this hould always be done in dry weather, that the weeds may be deftroyed. This ftirring of the ground between the plants will be of great fervice to promote their growth, and the ground will be hereby preferved clean from weeds, and by repeating it three times may be kept fo till the crops are fit for ufe.

In moift weather, plant flips or cuttings of Sage, Rofemary, Rue, Savory, Maftich, Thyme, Lavender, Stoechas, Lavender Cotton, and other aromatick plants; for, at this feafon, they take root very freely, efpecially if they are thaded from the fun, and duly watered.

Plant Garden Beans for a lattet crop, and continue fowing the Marrow-fat and other large kinds of Peas, to fucceed thofe which were fown in the former month; and alfo fome of the Hotrpur Peas thould now be fown, at three different times in this month, to have a fucceftion of them for the beft table. 
Apr. The Gardeners Kalendar. $\quad$ og You may yet llip Artichokes and plant fuch of them as are good for a late crop upon a moift foil ; but if the foil is dry, they will not produce fo large heads, nor fo furely bear fruit the firft feafon as thofe which were planted the laft month. In the middle of this month plant out thofe Cauliflower plants, which were raifed in February for a latter crop. Thefe hould have a moift foil, for in dry land if the feafon does not prove wet they feldom produce good heads.

Continue to fow all forts of young fallet herbs, as Radih, Rape, Turnep, Muftard, $\mho^{3} c$. at leaft twice every week; for at this fearon they will foon be too large for ufe; but as the heat of the feafon increafes, thefe feeds fhould be fown in a more thady fituation; for in fummer they thrive beft on a north border.

Sow fome Cos, Cilicia, and other kinds of large Lettuces, to fucceed thofe which were fown the former month; but thefe alfo hould be planted out on a moift foil, otherwife (if the fummer hould prove dry) they will hoot up for feed, and not cabbage.

Tranfplant your young Celery, plants into beds of rich earth at about three inches diftance each way, obferving to water them duly until they have taken root; but in duing of this, you thould not draw up all the plants clean out 


\section{10 The Gardeners Kalendar. Apr.}

of the feed bed, but only thin them, taking out the large ones, and leaving the fmaller plants to get frength.

Hoe the ground between your rows of Beans and $P$ eas, and draw the earth up to their ftems, which will Atrengthen them; for by clearing the ground from weeds, the plants will thrive better.

After a thower of rain, draw the earth up to the Atems of your Cabbage and Cauliflower plants, which were planted either in autumn, or early in the fpring. "This is abfolutely neceffary, to guard their ftems from the fun and wind, which dry and harden them; but in doing of this there thould be great care taken not to draw the earth up into their hearts, which will deftroy them.

Be careful to deftroy fnails and flugs, which; at this feafon, are invited abroad by gentle Mnowers of rain, when they may be eafily taken; for if they are fuffered to remain, they will foon increafe greatly, and become very troublefome and deftructive to many of your crops.

If the nights prove cold, you mut be careful to cover the glaffes over your early Cucumbers and Melons; for the young fruit is very fubject 


\section{Apr. The Gardeners Kalendar. II I}

fubject to drop off where the beds are grown cool, or proper coverings are wanting.

Sow Turneps on a moil fpot of ground, to fucceed thofe which were fown the laft month; thofe which were then fowed hould now be hoed out to a proper diftance, cutting up all the weeds between them.

Your beds of Mint, Tarragon, Parfley, छेc. Thould now be carefully weeded; for if the weeds are permitted to get above the plants, at this feafon, they will draw them up weak, and fpoil them: and if the feafon fhould prove dry, the beds thould be watered, which will greatly promote the growth of the plants.

You may now plant cuttings or lips of Mint, Tarragon, Ec. to make new beds where they are wanted, for the old plants are apt to decay, after they have ftood two or three years.

Tranfplant fome of your Cilicia, Cofs, and other large kinds of Lettuces, which were fown on a moderate hot-bed in February, obferving to water them if the weather proves dry, unvil they have taken new root.

The Cabbages and Savoys, which were fown the laft month, hould now be thinned and pricked out into beds, that they may acquire Atrength before they are tranfplanted out for good; and the feed-beds murt be weeded, 


\section{I1 2 The Gardeners Kalendar. Apr.}

to prevent thofe plants which are left remaining in the feed-beds from being drawn up tall and weak, by the weeds growing among them. You hould now fow fome Savoy and Cabbage feed for the lateft crop, to fucceed thofe which were fown the former month.

Sow Hemp and Flax, and pole Hops; at the fame time you hould clear your Hop ground from weeds, and make up the hills: you may alfo fow fome late Rouncival, and large Grey Peas, in the open fields, for winter provifion, if the ground is cool and moift.

The latter end of this month you fhould look over your Artichokes, and draw out all the young plants which have been produced fince the ftocks were flipt; for if thefe are permitted to remain on the old roots they will rob the plants, which are left for fruit, of their nourihment, and caufe the fruit to be fmall. Some of the beft of thefe plants may be trimmed and planted, where there are any wanted to repair a young plantation; but as thefe late plants rarely produce fruit the firft year, they are feldom planted, except there be great want of them.

Sow fome more Celery feed about the middle of this month, to fucceed that which was fown the former month; but this Mould be 
Apr. The Gardeners Kalendar. II 3 fown on a moift fpot of ground, and in dry weather carefully watered and fhaded from the fun, otherwife it will not come up.

You muft alfo fow fome Finnochia feed, to fucceed that which was before fown; for when it is fit for ufe, it will not continue more than eighteen or twenty days before it will run to feed; fo that there is an abfolute neceffity of having a fucceffion where this herb is required.

Keep all young crops clean from weeds; for if, at this feafon, that work is neglected, it will require much more labour afterwards, be. fide if weeds are permitted to grow among the young plants, the crops will be greatly injured by them.

Products of the KITCHEN-GARDEN.

Sprouts of Broccoli, Cabbages, and Savoys, are now very good, if they are gathered before they run up to feed. The young hoots of Turneps and Hop tops, are often eaten when there is a fcarcity of other greens, all forts of young Sallet herbs, Spinach, Radihes, Afparagus, Coleworts, Parney, Alifanders, Chard beet, fome late Celery, and Endive, is moint ground; Sorrel, Burnet, Thyme, Hyrop, Winter Savory, Pot-Marjoram; Brown Dutch, 
I14 The Gardeners Kalendar. Apr. and Cabbage Lettuces, in warm borders; alfo fome Cos Lettuce, where they have efcaped the froft, will be fit for ufe toward the end of the month; Chervil, young Onions, Leeks, Cives, Scallions, Rocambole, Borage, Sage, Rofemary, and fome Parfneps and Carrots, where they have been preferved in fand; for where they have remained in the ground, thofe which are found will have fprouted, after which their roots will become fticky and tough. Young Carrots, which were fown in autumn, are now in prime; and the young thoots of Salfafy or Tragopogon, which is by fome perfons preferred to Afparagus. Upon the hot-beds, Cucumbers, Peas, Kidney-Beans, and Purflane; and, toward the end of the month, you have often Peas on warm borders where they have efcaped the froft, and fome early Cabbages.

Work to be done in the FRUIT-GARDEN.

In the beginning of this month you may graft fome late kinds of fruit, provided the feafon be backward; but if the fpring is forward, it will be too late for this work, for if the Cions have puthed out leaves, they feldom unite with the ftocks. 


\section{Apr. The Gardeners Kalendar. II 5}

Look carefully to your young fruit trees which were planted in the fpring, obferving to water them in dry weather; and, if you obferve their leaves beginning to curl up, you mould water them gently all over their branches: this may alfo be practifed to great advantage on old trees, when you find their leaves are curling; but it muft not be done in the heat of the day, left the fun fhould fcorch their leaves; nor too late in the evening, efpecially if the nights are cold. Where you obferve the fruit trees to be greatly infefted with infects, you hould fteep a goud quantity of Tobacco ftalks in water, with which the trees hould be wahed; which, if carefully done, will deftroy the infects, and not do any injury to the trees; or if the leaves which are much curled are taken off, and fome Tobacco duft thrown on the branches, it will defroy the infects, and may in a day or two after be wafhed off again.

Thofe fruit trees which were inoculated the latt fummer, and have fucceeded, Miould have the ftocks cut down to three or four inches above the bud the beginning of the month (if it was not done the formermonth); for now the buds will begin to thoot if the flocks are cut down in time, otherwife the buds mifcarry or 


\section{The Gardeners Kalendar. Apr.}

if they do break out, are fo much weakened by the growth of the ftocks, as to render the thoots of the buds very weak.

Toward the end of this month you muft begin to look over your walls and efpaliers of fruit trees, training in the regular kindly fhoots, and difplacing all foreright and luxuriant ones, where they are produced. This is alfo the time for thinning of Apricots, where they are too thick; for the fooner this is done, the better thofe will thrive which are left on.

Plant cuttings of Vines in the places where they are to remain, obferving always to have a knot of the oid wood to the bottom of each, and bury them fo deep in the ground, as that the uppermoft eye may be even with the furface of the ground; if this be rightly obferved, there will be little danger of their fucceeding.

Lnok over your Vines againft the walls, rubbing off all fmall dangling thoots, which are now beginning to pulh out; and where two hoots are produced from the fame eye, the weakeft, which is generally the under one, Thould now be rubbed off, in order to encourage the fhoots and alfo the fruit on the remaining branches : at this feafon, a great quantity of Vines may be looked over in a very thort time, and much labour faved, which would $\therefore$.

be 


\section{Apr. The Gardeners Kalendar. $\quad 117$}

be occafioned, fhould thefe fhoots be permitted to remain on a month longer. By this early rubbing off the young thoots, the fruit branches will be greatly ftrengthened, and the fruit forwarded by the branches being laid clofe to the wall, and the ufelefs thoots taken away.

Your beds of Strawberries muft now be carefully weeded, and their runners muft be taken off; and if the feafon proves very dry, it will be proper to water them, for when this is neglected they will produce but little fruit.

Keep the borders near fruit trees clean from weeds, and large growing plants; for thefe rob the trees of their nourinment. In fuch foils as are apt to bind very hard, the ground hould be loofened with a dung fork'; and if fome mulch be laid afterward on the furface of the ground, and in very dry feafons watered over cnce or twice a week, it will be of great fervice to both the fruit and trees. You Mould alfo keep the ground clear between the rows of Vines in the Vineyard; and in the beginning of the month the ftakes fhould be fixed to them, that the branches may be faftened thereto; which is better than to let the fakes remain to them all the winter, becaufe they would decay more in one winter than in two fummers; for the Vines need not be ftaked in 


\section{I1 8 The Gardeners Kalendar. Apr.}

that feafon, if the laft year's hoots of them are tied together to prevent their being broken by ftrong winds.

In the middle of the month uncover thofe Fig trees which were fcreened from the froft in winter; but this thould be done with caution; for the young fruit which now begin to appear will be in danger, if they are too fuddenly expoied to the open air.

The fruit in the forcing-frame muft now have a large fhare of freth air, in proportion to the heat of the weather; their branches mould alfo be frequently fprinkled over with water, which will be very ferviceable to the trees, and caufe the fruit to be fairer; and their roots muft be frequently watered, which will be of equal advantage to the trees and fruit.

\section{FRUITS in prime, or yet lafting.}

Pears; Franc-real, Bergamot Bugi, Saint Martial, Winter Boncretien, Lord Cheyne's Winter Green, Beffy de Chaumontelle from an efpalier; Carmelite, and, for baking, the $\mathrm{Ca}$ dillac, and Parkinfon's Warden.

Apples; Golden Ruffet, Pile's Ruffet, Wheeler's Rufiet, Nonpareil, John Apple, Stone Pippin, with fome others. 
Apr. The Gardeners Kalendar.

In the forcing-frame, Cherries, Mafculine Apricot, fome Plumbs; and on the hot-bed; Strawberries.

Work to be done in the NURSERY.

The beginning of this month may fafely be removed many forts of Evergreens, as Hollies, Yews, Pyracanthas, Alaternufes, Phillyrea, Ciftufes, Evergreen Oalss, Firs, Pines, Cedars, Cypreffes, Medicago frutefcens, Hairy Cytifus, Ec. obferving, if poffible, to do it in a cloudy day, or when there are howers of rain; becaufe the fun and wind are apt to dry the fibres of their roots, while they are above-ground, which is very injurious to them. Thefe new planted trees thould be well watered to fettle the earth to their roots; and the furface of the ground hould be covered with mulch, to prevent the fun and wind from penetrating to the roots of the plants.

At this feafon you may plant out the two forts of Laurel-leaved Tulip trees, the Carolina Bay, Candle-berry Myrtle, Carolina Spindle tree, Evergreen Caffine, Tupelo, and fuch other exoticks as are intended to he naturalized to this climate; for as thefe are to be turned out of the pots, the outfide of the balls of 


\section{I20 The Gardeners Kalendar. Apr.}

earth only hould be taken off, to give room for the new fibres to thoot out.

You may now fow Evergreen Oak Acorns, and the feeds of Firs, Pines, Cedars, Cyprefs, Magnolias, Tulip tree; as alfo feeds of moft exotick trees, which are brought from Carolina, Virginia, and the more northern parts of America. The particular directions for doing this are exhibited in the GARDENERS DICTIONARY.

The beginning of this month you may graft Hollies, and about the middle you may inarch Firs, Pines, Junipers, Éc.'by which method fome of the farce forts of evergreen trees may be propagated; but the trees thus raifed will never grow fo large as thofe raifed from feeds, the ftocks feldom keeping pace in their growth, with the trees inarched, fo that they are in danger of being blown out; for which reafon, whenever this is practifed, the inarchment mould be as near the ground as poffible.

You hould now look over your grafts, and obferve, where the loam is much cracked, to renew it, left the drying winds penetrate to the grafts, and deftroy them. Likewife the buds of fuch trees which are now hooting, hould be carefuily looked over, and where you obferve their tops infefted with infects, and their 


\section{Apr. The Gardeners Kalendar. I $2 \mathbf{r}$}

leaves curled, you thould pull them off before the infects fpread too far.

Keep the ground clean between the rows of trees in the nurfery; for if weeds are permitted to grow this month, they will foon over-top young trees, and greatly weaken thém: for there is nothing more prejudicial to trees, than fuffering the weeds to grow amongft them, efpecially in the fpring feafon.

If this month fhould prove dry, you muft diligently water your feed-beds of Evergreens, foreft trees, and Mrubs, which hould alfo be maded from the fun in the heat of the day; the young plantations of thofe which were drawn out of the feed-bed, and the ftocks for fruit-trees, which have been lately planted, muft be watered in very dry weather; for thefe being fmall, the fun and wind will foon penetrate to their roots, and dry them up. This is to be underftood of fmall plantations; for in large nurferies, it would be a great work to water all the ftocks.

The beds wherein you fowed feeds either in autumn or the laft month, fhould now be carefully weeded, for the young trees will many of them begin to appear; fo that if the weeds are permitted to grow, their roots will be fo much entangled with the plants, as to render 


\section{The Gardeners Kalendar. Apr.}

render it very difficult to pull them up without drawing the plants up with them; and as the weeds are of a quicker growth than the plants, fo they will foon over-top them, and retard their. growth. The tubs or pots of Cedars, which are beginning to come up, muit now be removed to a Mady fituation; for too much fun will foon deitroy thefe young plants. You mut now be careful to guard your feed- beds of Pines and Firs, which, toward the end of the month, will begin to appear, from the birds, which are very apt to peck off the tops of the young plants, as they thruft out of the ground, with the hufk of the feeds upon them, which are always brought up upon the head of the plants.

Work to be done in the PIEASURE-GARDEN.

The gravel walks, which were broken up and turned the laft monih, fhould in the beginning of this be raked level and rolled, that they may be ready for ufe; and the grafs walks and lawns in view from the houle muft now be duly mowed, for this is a feafon when mott people delight to walk out; fo that the walks of the garden ought to be well kept. Befide, where this is neglected, in the fpring, the 
Apr. The Gardeners Kalendar. $\quad 123$ grafs will foon become rank and coarfe, fo as to be fome time before it can be gotten fine again, where the greatent care is afterward taken of it.

Clean the borders of the pleafure-garden from weeds, and tie up all tall growing plants to fticks, to prevent their being broken, of blown down by wind.

You may now fow fuch annual flowers in the borders, as do not require any artificial heat to bring them forward; fuch as Candy Tuff, Venus Looking-glafs, Lupines of feveral forts, Sweet Peas, Tangier Peas, Dwarf Lychnis, Lobel's Catchfly, Venus Navelwort, Convolvelus Minor, Nafturtium Indicum, Flos Adonis, Lavatera, Oriental Mallow, Carthamus, or Baftard Saffron, Hieraciums of feveral forts, Centaurea's, Lotus of feveral kinds, Snails, Caterpillars, Linarias, Securidaca, Aftragalus, Moldavicas, with fevera! other hardy kinds of annual flowers, which thrive better, if fown where they are to remain, than if they are tranfplanted; therefore they thould be fown thin in patches, upon the borders of the pleafure-garden; and when they are come up, they fhould be thinned, leaving but few plants in each patch to flower, that they may be the flronger. 


\section{The Gardeners Kalendar. Apr.}

In this month you thould fow moft forts of hardy perennial and biennial plants in the flower nurfery, which were not fown the former month; as Canterbury Bells, Sweet Williams, Pinks, Carnations, Hollihocks, French Honeyfuckles, Stock Gilliflowers, Wall-flowers, Centaureas, Everlafting Pea, with many other forts, which are raifed in the flower nurfery to fupply the borders of the pleafure-garden.

The beginning of this month you may make fome flender hot-beds, to fow fuch of the annnals as require a little warmth to bring them forward; but will do better, if raifed under a covering of mats, than under glafies, which generally draw them too much; and though they are fomewhat later in this management, yet there is no inconvenience in that, becaufe they are defigned to come in autumn, when there is a fcarcity of other flowers, which renders them the more acceptable: of thefe are the African and French Marigold, Convolvulus Major, Balfamines, Marvel of Peru, Sweet Sultan, Indian Pink, with fome others.

You muftnow make freth hot-beds for tranfplanting your tender annuals, as Aramanthufes, Gomphrena, Hibifcufes, Double ftriped Balfamines, $\mathcal{E}^{2} c$. which muft be brought forward at this feafon; otherwife they will not a 
Apr. The Gardeners Kalendar. I25 rive to any degree of beauty, which chiefly confifts in their ftrength. Nor will they perfect their feeds, efpecially if the autumn feafon meuld prove cold.

You hould now tranfplant the young plants of the China Starwort, either upon a moderate hot-bed, or on a warm border, to acquire ftength, obferving to water and fhade them until they have taken root.

Put fome more roots of Tuberofes into a moderate hot-bed, to fucceed thofe which were planted the former month, that there may be a continuance of their flowers through the feafon.

The feeds of choice Carnations and Pinks muft now be fown, either in pots, tubs, or borders; but there mult be care taken not to bury the feeds too deep, by which they are often deftroyed. Thefe mult be gently watered in dry weather, otherwife the plants will not come up.

The pots or tubs of feedling Auriculas and Polyanthufes muft be carefully fcreened from the fun; for if they are expofed to its full heat but one day, it will deftroy them while they are young; they muft alfo be frequently refrefhed with water.

Set fticks to the Carnations, which now begin to Thoot up their fpindles for flowering; and faften 


\section{I26 The Gardeners Kalendar. Apr.}

faften the ftems thereto, with bars matting, to prevent their being broken by the wind; and care fhuuld be taken to guard them from fparrows, otherwife thefe birds will peck off the inner or heart leaves to the fumps.

The fine Auriculas will now begin to thew their beautiful flowers; therefore the pots Should be removed under fome covert, to preferve them from wet, which would wath the mealinefs from off their flowers, in which great part of their beauty confifts: they hould alfo be defended from the heat of the fun, which would haften their decay; but they muft have as much free air as poffible, otherwife the flower ftalks will draw up very weak. Thefe pots are ufually placed on Belves, which are framed fo as to rife above each other, which is very proper for fuch flowers, as they are of humble growth, otherwife the pots mun be taken up to view the flowers: but as thefe ftands are always covered over to keep off the rain and fun, fo the front mould be kept open at all times, when the weather will permit: and thofe of them, from which feeds are propofed to be faved to obtain new flowers, Should be removed into the open air, as foon as they are fully blown, and placed where they may have the 
Apr. The Gardeners Kalendar. I 27 morning fun, and a free air, without which they rarely produce good feeds.

This is alfo a good feafon for taking off the nlips of choice Auriculas, to make an increafe of them. Thefe flips thould be put into fmall pots, and placed in the fhade, obferving to water them in dry weather gently, until they have taken root; but if any of the lips taken off thould be deftitute of fibres, they hould be clofely covered with fmall glafies, to forward their putting ont of roots.

The beds of fine Ranunculufes, Aneraonies, Tulips, and Hyacinths, which are now in flower, thould be covered either with mats or cloths, to defend them from wet, and the heat of the fun ; by which method, they may be preferved a much longer time in beauty than they naturally remain when exporfed to the open air ; but the covers thould be taken off every morning and evening, when the weather will permit, that they may enjoy as much of the free air as poffible, without which the flowers will not continue long in beauty, and their roots will be greatly weakened.

Toward the latter end of this month take up the roots of Saffron, Colchicums, Yellow Autumnal Amaryllis, and fuch other bulbousrooted flowers as blow at Michaelmas, whofe 


\section{The Gardeners Kalendar. Apr.}

leaves are decayed. Thefe may be kept out of the ground until the beginning of Augurt, when they muft be planted again.

Tranfplant fuch forts of evergreen trees and Ihrubs, which have not begun to thoot, thefe may be fafely removed, provided the air is clouded, and there is a profpect of rain in a Thort time; but if the ground is very dry, where they are to be planted, large holes thould be opened in proportion to their fize where they are to be placed, and a large quantity of water poured into each, fo as to render the ground like pap or mud; then place the trees therein, and after the earth is filled in about the roots, make the furface hollow like a bafon, to contain water; and cover it with mulch, to prevent the fun and air from penetrating the ground to dry their roots; and repeat watering the trees once a week, provided the weather thould prove diy.

Where Phillyreas, Alaternufes, Laurels, Lauruftinufes, or other hardy evergreen trees, are grown rude, they may now be reduced to the figure you intend, by cutting their branches in clofe to the ftems; and when they hoot, they may be trained to the order defired. 
Apr. The Gardeners Kalendar. $\quad 129$

Plants now in Flower in the PLEASUREGARDEN.

Anemonies, Ranunculufes of various kinds, Polyanthufes, Auriculas, Tuilips, Crown Imperials, Hepaticas, Hyacinths of various forts, Narciffures, Daffodils, Jonquils, Violets, Mufcarias, Dwarf-flag Iris, Great Snowdrop, Spring Cyclamens, Spring Colchicums, Pulfatillas, Bulbous Fumitury, Rofe-root, Ducksfoot or May Apple, Wood Anemony, Friers Cowl, Italian Arum, Double Ladies Smock, Double Pilewort, Starry Hyacinths, Dog'stooth, Double Daifies, Fritillarias of various kinds, Gentianella, Double Caltha Paluftris, Columbines, large green-flowered Ornithogalum, Perfian Lily, Orchifes of feveral forts, Sanguinaria, Solomon's Seal, American Lungwort, Meadia, Hemorocallis with yellow flowers, Double Saxifrage, Venetian Vetch, Lychnifes, Alyffon Creticum, Bugle, Cats-foot, Lily of the valley, Dame's Violet, Leopards-bane, Honeywort, Leontopetalon, Heart's-eafe, Periwinkle with fingle fowers, both fmall and large, as alfo with double flowers of a purple colour, Borage-leaved Verbafcum, blueflowered Perennial Moth-mullein, with fome others. 


\section{30 The Gardeners Kalena'ar. Apr.}

\section{Hardy Trees and Sbrubs now in Flower.}

Lilac with white, purple, and blue flowers, Perfian Lilac with Privet leaves, commonly called the Perfian Lilac with intire and with cut leaves, Laburnums, Double-flowering Peach tree, Double-flowering Pear tree, Cherry Plum, Almond with white and Peach-coloured Bloffoms, Amelanchier, Aria Theophrafti, Viburnum, Bird Cherry, Cornih Cherry, Arbor Judæ, Double-flowering Cherry, Cockfpur Hawthorn, Dwarf Almond with fingle and double flowers, Hypericum frutex, Benjamin tree, Berberry tree, Bilberry burh, Bladder nut, Service tree, Turpentine tree, Early white and Italian Honeyfuckles, Yellow Jafmine, Lauruftinus, Scorpion Sena, Caragana, Eaftern-Bladder Sena, Dwarf Cherry, Coronilla Cretica, Siberian Cytifus, Single Virgin Rofe, Shrubby Spring Anonis, Hairy Cytifus, Laurel, Pyracantha, Glaftenberry Thorn, Nettle tree, Dogwood, Spindle tree, Quicken or Mountain AR, Scarlet flowering Maple, Horfe Chefnut, Spirea frutex, Upright and Fly Honeyfuckle, with fome others. 


\section{Apr. The Gardeners Kalendar. I I I}

Medicinal Plants which may now be gatbered for UJe.

Brooklime, Water-creffes, Wood-roof; Moufe-ear, Daify, Rue-leaved Whitlow-grafs, Bugle, Shepherds-purfe, Dandelion, White Saxifrage, Coltsfoot, Hare-bells, Ground Ivy, Dead-nettle, Wood Sorrel, Cowllip, Primrofe, Radih-root.

Work to be done in the GREEN-HOUSE and $\mathrm{STOVE}$.

The Indian Bay, broad Mining leaved Lauruftinufes, Myrtles, Ciftufes, Teucriums, Phlomifes, Olives, Carobs, Melianthufes, Tree Wormwood, Oleanders, and other lefs tender plants, may be taken out of the green-houfe toward the middle or latter end of the month, according as the feafon proves favourable, that the Orange trees, and other more tender plants, may be placed thinner, that they may have a greater hare of air; but thofe plants which are taken out, hould be placed where they may be defended from cold winds; otherwife they will fuffer, being made fomewhat tender by tanding in the houfe. 
132 The Gardeners Kalendar. Apr.

Such Orange trees, or other exotick plants, as want Mifting, fhould now be removed; and thofe which require larger pots or tubs muft be placed therein, obferving, when they are taken out of the tubs or pots, to part off all mouldy or decayed roots, and wah their ftems and heads, to cleanfe them from the filth they have contracted by remaining in the houfe; and when they are new planted, they mould be duly watered; fuch of them as are expofed to the open air thould be placed where they may be fcreened from the winds, and Thaded in the heat of the day from the violence of the fun. By removing the Orange trees early in this month, they will have time to make new roots before they are fet abroad, and will have ftrength to produce their flowers in plenty.

Thufe Orange trees which are not removed at this feafon, thould have the earth taken out of the tops and fides of the tubs or pots, and filled up again with freth rich earth, and their ftems and heads cleaned as befere: this will ftrengthen them greatly for flowering; but you mould never apply any hot kinds of dung to the furface of the earth, as is by fome unfkilfully practifed, to the deftruction of their trees. If therefore you would lay any dung upon the 
Apr. The Gardeners Kalendar. I33 furface of the earth in the tubs, it thould be rotten neats dung; but this thould not be done in too great quantities; and it fhould be thoroughly rotted.

Open the windows of the green-houfe moft part of the day, when the air is mild: for at this feafon, the plants require a large fhare of frefh air, otherwife their thoots will draw up weak, and produce but few flowers, and will be lefs able to bear the open air, when they are removed out of the houfe.

You may now graft Oranges, Jafmines, and other tender plants, by approach; but fuch as will take buds, are better if propagated that way; for trees inarched feldom unite fo well with the graft, and never grow to fo large a fize as thofe which are budded; fo that this method of inarching trees is feldom practifed, except on thofe forts which cannot be propagated fo eafy any other way, or for the fake of having fruit upon the trees foon; for by inarching a branch with young fruit on it, the graft may be feparated from the old tree when it is well united with the ftock, and fo a bearing tree may be procured the fame feafon; but thefe feldom laft long, or make much progrefs.

The bark-beds in the fove, which have declined their heat, and were not renewed the former month, fhould now be ftirred up with 


\section{I34 The Gardeners Kalendar. Apr.}

a fork to the bottom,' and fome frefh bark added thereto, which will renew their heat; at the fame time fuch plants, as have rooted thro' the pots, Mhould be Mifted, fome of which hould be put into larger pots, giving them frem erath. However it will not be prudent to enlarge the pots too often, for if thefe plants are over potted, they will not thrive, therefore it will be much better to pare off their roots, on the outfide of the balls of earth, and put them into pots nearly of the fize, and then plunge them down into the bark again immediately; but this work muft be done when the air is warm, becaufe there will be a necefitity to open the glaffes pretty often; and, if the air be fharp, it will injure the plants.

The Ananas or Pine apples munt now be carefully tended, obferving to refreth them often with water, as alfo to preferve a kindly heat in the beds, and fuch plants as are removed into frames, mould be well covered with mats every night to keep them warm; but in the middle of the day when the weather is hot, they hould have air admitted by raifing the glafies in proportion to the warmth of the fealon, otherwife they will be in danger of fcorching; and the young plants, which are for the next year's fruit, frould be now fhifted 
Apr. The Gardeners Kalendar. I 35 into thofe pots they are defigned to remain until the beginning of Auguft, when they muft be planted into thofe pots, in which they are to remain for fruiting.

Shift fuch of the feedling exotick plants as require it, into larger pots, and ftir up the bark of the beds to renew their heat, adding fome frefh $\tan$ to the beds; and then plunge the pots down again, obferving to water and fhade them until they have taken root.

The Coffee trees will now begin to flower; therefore their leaves and ftems muft be cleaned from filth, by wahing it off whenever it appears; and refrefh the trees with water two or three times a week, according to the warmth of the feafon, which will caufe them to flower ftrong.

Plants in Flower in the GREEN-HOUSE and STOVE.

African Geraniums of feveral forts, Ilexleaved Lantana, Candy Tuft tree, African Anthericum with Aloe Leaves, and two or three forts with Onion leaves, Tree Scabious, Ciftufes, three or four forts of Arctotus, Mefembrianthemi of feveral forts, Aloes of feveral kinds, Coronilla Cretica, Cytifus Canarienfis, Medicago frutefcens, Aleppo Cyclamens, Her- 
36 The Gardeners Kalendar. Apr. mannias of four or five forts, Colutea $\mathbb{E}$ thiopica, Polygala Africana, Hypericum Balearicum, two forts of African Shrubby Tanfey, Threeleaved African Sumach, Melianthus minor feetidus, Cotyledons, Turnera, Malpighia of two or three forts, Humble plant, Ciftus Halimi folio, Olive tree, Watfonia, African Sifyrinchium, Arum Æthiopicum, Crinum, Cunonia, African Hyacinth with fmooth and with warted leaves, Dumb Cane, Rauvolfia, Waltheria, Atamufco Lily, Pancratium, Small creeping Cereus, Cannacorus, Ixia of three or four forts, Antholiza, Shrubby African Starwort of two forts, Tetragonia, Clutia, fome forts of Acacia, Diofma of two forts, African Shrubby Sage with yellow and blue flowers, Shrubby Stachys from the Canaries; Teucrium Bœricum, Shrubby Convolvulus from Crete, Heliotropium Scorodoniæ folio, Coral tree, Hæmanthus Colchici foliis, black flowering Lotus, Tree Houfeek, Craffula, African Wood Sorrel with large purple and alfo with yellow flowers, China Rofe, Elichryfum Orientale, Spanifh Toad-flax, Ornithogalum from the Cape of Good Hope, African Marigold two forts, Chyfocoma, Euphorbiums, Sorrel tree, Lycium with narrow leaves, Canary Shrubby Fox-glove, Othonna two or three forts, Peruvian Heliotrope, African Cacalia, with fome others. 


\section{[ 137 ]}

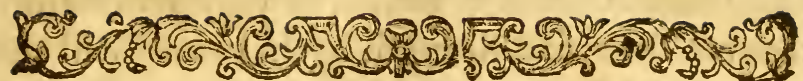

\section{A $\quad$ I.}

Work to be done in the KITCHENGARDEN.

Dener iv. 20. 1 growth of moft efculent plants; 6. Peas which are in flower (efpecially thofe on dry lands) frequently fuffer greatly; moft of their bloffoms falling off before their maturity, fo that they are not fucceeded by pods. But when this month happens to be wet, the markets are plentifully ftocked with moft forts of garden plants. But this does not only increafe the quantity of plants, but alfo a great plenty of weeds, whereby the labour of a kitchengarden is more than double of what is required in a dry feafon; for if the young crops are neglected but a very thort time in moint 
$13^{8}$ The Gardenars Kalendar. May. weather, the weeds will get the better of them, and weaken them fo much, as they will hardly recover their full ftrength again; nor will the plants (with all poffible care afterward) ever arrive to the fize they would have grown to, provided they had not been finted by the weeds. Befides, many forts of weeds will perfect their feeds in a fhort time, which; being fhed upon the ground, will occafion a great deal of labour for feveral years to extirpate them again. Among thefe are Shepherd's-pouch, Groundfel, Dandelion, Fumitory, Pimpernel, Chickweed, and fome others. And thofe of them which do not feed fo early, will (if let ftand) eftablifh themfelves fo firmly, as to occafion much labour to get them out of the ground; fo that it is certainly the beft way to clear all forts of crops from weeds as foon as poffible in the fpring, and keep them conftantly fo.

The fame caution is neceffary in regard to your dunghills; for, at this feafon, there will be great quantities of weeds produced thereon; as alfo upon the heaps of comport, which, if not deftroyed in time, will thed their feeds, whereby the garden and pots will be plentifully focked, from the manure or comport which is carried into it. 


\section{May. The Gardeners Kalendar. $\quad$ I39}

In the beginning of this month you fhould fow Purnane, in the open ground, and a little Endive for blanching early in the feafon, but this which is fown fo early is apt to run up for feed very foon, fo muft not be depended upon to fupply the table long; continue to fow all the forts of fmall fallet-herbs every three or four days, otherwife there will not be a fupply of thefe fit for ufe; for, at this feafon, they foon grow too large : but thefe hould be fown in a north border, where they may have little fun, or be well maded in the heat of the day.

Sow Peas, and plant Beans, for latter crops; but this fhould be done on a moift foil; otherwife they feldom fucceed well, unlefs the feafon is uncommonly wet and cold.

Plant Kidney Beans for a fecond crop: the large Dutch fort and the fcarlet bloffom Beans are the beft for this feafon, becaufe they will continue bearing much longer than any other, and are alfo far better for the table; about the twenty-third day of this month you fhould fow Cauliflowers, for winter ufe, obferving to fhade the bed with mats every day, and keep the ground moift; otherwife the feeds will dry, and the plants will come up very fparingly; the plants which are raifed at this 
I40 The Gardeners Kalendar. May. feafon will produce their heads in October and November, and in mild feafons fome will consinue till near Chriftmas.

In moift weather, plant out to the places where they are to remain, the red and white Cabbages and Savoys for winter ufe, and tranfplant the firft fown Celery into drills for blanching, which will come early, if planted in this month.

The early crops of Spinach and Radifhes being by this time taken off the ground, the weeds thould be cleared from the Cauliflower and Cabbage plants, Beans, or any other crops, which were planted on the fame ground; and, in moif weather, draw fome earth about the ftems of the plants, which will keep the roots moift, and prevent the fun and wind from drying their ftems, to which if they are expofed, it will greatly retard the growth of the plants; but in doing of this, great care fhould be taken not to raife the earth fo high about them, but efpecially the Cauliflowers fo as to fall into the center of the leaves, which will entirely deftroy thefe plants.

Tranfplant Radifhes for feed, placing them in rows three feet diftance, and two feet afunder in the rows; obferving to make choice of fuch only as have long, ftrait, well-coloured 
May. The Gardeners Kalendar. I 4 II roots and fmall tops, rejecting all fuch as are forked, or Thort rooted; for which reafon it is, that the moft curious gardeners never fave feeds from fuch as remain where they were fown, becaufe they cannot judge of the length or goodnefs of their roots.

The Cucumbers which are under frames, and have not a fufficient depth of earth upon the dung, muft be carefully haded with mats in the heat of the day; for the fun is often too violent at this feafon for thefe plants through glaffes; but the Melon plants fhould be gradually hardened to bear the open air in the day time in warm weather, for the greater hare of air they enjoy at this feafon, the better will the fruit fet upon the Vines; and where the earth is laid of a proper thicknefs upon the dung, the Vines will not hang down or droop their leaves, but bear the fun well ; for it is from the Thallownefs of the earth on the beds, that the Vines of Cucumbers and Melons are fo frequently obferved to thrink in hot weather, and this alfo occafions their decay much fooner than they would do, if their roots enjoyed a proper depth and width of foil, for the roots of thefe plants fpread as far in the ground, where it is laid on the fide of the beds, as their Vines extend on the furface; fo that where the beds 
I42 The Gardeners Kalendar. May. are but hallow or narrow in earth, the Vines will require hading in the great heat of the day: but the covering fhould not remain on too long, which is as great a fault on the other fide; for it is only the mid-day fun which can be too violent for the plants, and that only in extreme hot days, which fometimes happen in this month. But fuch plants as have been raifed under hand glaffes for the fecond crop, Thould have full liberty to grow, by raifing the glaffes upon three bricks or forked fticks, and the ends of the plants laid out from under the glaffes: but this muft not be done too foon, efpecially if the nights are cold; which if it chould fo happen after the plants are laid out, - they muft be covered with mats every night, to prevent their being nipped by the froft.

When the Melon plants are fuffered to run out from under the glaffes, the paths between the ridges hould be filled up level with the ground on the ridges, and the whole trodden down very hard; which is a fure method to caufe the fruit to fet, provided the plants have no water and they are expofed to the open air at all times in the day when the weather will permit.

The early Cauliflowers will now begin to appear in the center of the plants; therefore they 
May. The Gardeners Kalendar. $\quad 143$ they hould be carefully looked over every day, breaking down fome of the inner leaves of fuch as appear in flower (as it is ufually termed) to preferve them white; for if they are expofed to the fun and air, they will change yellow in a fhort time.

Hoe winter crops of Onions, Carrots, Leeks, Parfneps, and Beets, to clear them from weeds; for this method of hoeing between crops is far preferable to hand weeding, becaufe the whole furface of the ground being ftirred, the fmall feedling weeds will be deftroyed, and the plants are greatly forwarded in their growth; and the keeping your crops clear from weeds in this month will be of great fervice to them, and fave much labour the fucceeding months.

Tranfplant Cilicia, Cos, Imperial, and Brown Dutch Lettuces into north borders, to fucceed thofe planted the laft month; and toward the end of the month you may fow fome Cos, Cilicia, Brown Dutch, and common Cabbage Lettuces, to fupply the table in Auguft; but thefe feeds muft be fown in an open fituation, for walls, pales, or hedges, will draw the plants up weak.

Sow Finnochia in drills, about eighteen inches or two feet afunder, to fucceed that 
144 The Gardeners Kalendar. May. which was fown the laft month; and draw the earth up to the plants which are almoft full grown, to blanch them.

$N . B$. This hould have a light, rich, moift foil, when fown at this feafon; otherwife it is apt to run to feed, efpecially if the feafon proves dry.

You may yet plant flips of Sage, Rofemary, Hyflop, Lavender, Marum, Maftich, and moft other aromatick plants, obferving to thade and water them until they have taken root; but it is much better to plant thefe llips juft before they hoot, becaufe the fhoots which have been produced the fame feafon, are tender, fo droop and frequently decay, whereby the lips do not take fo well.

The early Cabbages now begin to turn their inner leaves for cabbaging, which may be forwarded by tying their leaves together, either with a withy or bafs mat, as is practifed by the gardeners near London, which caufes them to whiten within much fooner than they otherwife would, whereby they have them fit for the market a fortnight or three weeks earlier in the feafon.

Look over your Artichokes again in this month, and pull up all the plants from the roots, which have been produced fince the old 
May. The Gardeners Kalendar. 145 ftocks were flipped; for thefe will draw the nourifhment from the plants which were left for fruit, and caufe the heads to be fmall. You hould alfo cut or pull off all the fmall Artichokes which are produced from the fides of the ftems clofe to the leaves; for if thefe are permitted to grow, they will render the principal Artichokes on the top very fmall. Thefe the gardeners term Suckers, and they are, by the kitchen gardeners, tied up in bunches, and carried to market. And are frequently eaten raw with vinegar, falt, and pepper, and are by fome foreigners much efteemed.

You may now fow Skirrets, Salfafy, and Scorzonera, for the laft crop; for that which was fown early, will foon run up to feed ; efpecially the Skirret, which, when fown too eariy, is feldom good.

Sow Turneps, when there is a profpect of rain in a fhort time, which will bring up the plants very foon; and hoe thofe Turneps which were fown the laft month, leaving them about eight or ten inches afunder, which will be a fufficient diftance for thofe which are intended to be drawn very young.

Toward the latter end of this month hould be fown fome Broccoli for fpring ufe; and a. Wter crop ôf Savoys should be fown, to fucceed 


\section{I46 The Gardeners Kalendar. May.}

thofe which were fown the former month; for thefe will be fit for ufe after Chriftmas, when the others are gone.

Sow Cucumbers in the open ground, toward the end of the month, to produce fruit for pickling; and plant out Gourds and Pompions upon dunghills, $\Xi^{2} c$. where they thould be allowed a large compafs to fpread, otherwife their vines will interfere and fpoil each other.

The ftalks of your Onions, which were planted for feed, will now be grown to their full height; therefore you hould provide a parcel of ftakes, which thould be driven into the ground, at about eight feet diftance from each other in the rows; and fome lines fhould be faftened from itake to ftake on each fide, to fupport the ftems of the Onions; otherwife they will be broken down by the wind, whereby a great part of them will be fpoiled.

The fame care fhould be taken of your Cabbages, Carrots, Parfueps, Savoys, Broccoli, and Leeks, which were planted for feeds, and are now run up to flower; for when the feeds are formed, it will render their heads too heavy to be fupported by their ftems without help; for as they grow pretty tall, they are frequently broken by the wind; fo that they mould al- 


\section{May. The Gardeners Kalendar. $\quad$ I47} ways be fupported by lines and ftakes, as foon as they begin to flower.

The. Tomatos for foups, and the Capficums for pickling, which have been raifed upon botbeds, thould be tranfplanted to the places where they are defigned to remain: toward the end of the month, if the weather proves favourable, the Tomatos hould be planted near a wall, pale, hedge, or efpalier, to which the plants, when grown, mut be faftened, to fupport them; otherwife they will fall on the ground, which will prevent the fruit from ripening, and caufe it to rot in the autumn, efpecially in moift weather: the Capficums thould be planted in a rich foil and a warm fituation, and in dry weather they muft be frequently watered to have plenty of pods.

\section{Products of the KITCHEN-GARDEN.}

Radines, Spinach, feveral forts of Cabbage Lettuce, Sorrel, Mint, Balm, Winter Savory, Borage, Buglors, Spring Coleworts, Tragopogon, the young fhoots of which are by fome preferred to Afparagus, young Onions, Cives, Afparagus, Peas, Beans, fome early Artichokes, Cauliflawers, early Cabbages, young Carrots from under walls and hediges, Cucumbers,

$$
\mathrm{L}_{2} \text { Autons, }
$$




\section{The Gardeners Kalendar. May.}

Melons, Purnane, and Kidney-beans on hot-beds, Mulhrooms, Parfley, Coriander, Chervil, Crefies, Muftard, and all forts of fimall falleting, early Turneps, Burnet, Tarragon, with many other forts of fpring herbs.

\section{Work to be done in the FRUIT-GARDEN.}

In the beginning of this month you muft look over your wall and efpalier trees, and carefully take off all foreright fhoots and fuch as are luxuriant or ill placed; and train fuch kindly branches as you would preferve, regularly to the wall or efpalier, which will prevent your trees from growing into confufion; and ftrengthen the fruit branches, as alfo admit the fun and air to the branches and fruit, which are often obftructed by the luxuriant growth of thofe fhoots, to the great prejudice of them both. The neglect of doing this work early will occafion much more trouble, and greatly injure your trees. For where this work is neglected in this month, the trees cannot be brought into fo good order by any aiter-management the fame year.

Where Apricots and Pcaches have been left too thick, when firf looked over, they flould be thimed the beginning of this month, obferving 


\section{May. The Gardeners Kalendar. I 49}

never to leave two or more fruit together (as is too often practifed by covetous perfons) tho' there be but a fmall crop on the trees, for the leaving of the fruit fingle will make thofe which are left on much larger, and better favoured, and render the trees fronger for fucceeding years: whereas, when they are overcharged with fruit, they are often fo much weakened, as not to be recoverable in lefs than three or four years, notwithftanding they may be under the moft Rilful management; befides, one dozen of fair well-flavoured fruit is preferable to five or fix dozen of thofe which are fmall and ill-nourihed, and will fell for more money in the markets. 'The diftance which rhould be allowed to all forts of fruits muft be proportionable to their ufual fizes; for inftance, the middling or fmall Peaches and Nectarines, five or fix inches afunder is fufficient; but for the large forts, eight inches is full near enough. This muft alfo be proportioned to the ftrength of the trees, and alfo of the branches on which they grow: for weak trees frould have a lefs number of fruit left on them than thofe which are frong, becaufe they are lefs capable of nourifhing them; and fuch branches as are weak, muit not have much fruit left on them for the fame reafon, becaufe

$$
\text { L. } 3 \text { when }
$$


I50 The Gardeners Kalendar. May. when branches are over charged with fruit, they are often rendered fo weak as to be liable to fuffer by the leaft inclemency of the feafon. Peaches and Nectarines, whofe fruits are only produced on the hoots of the former year, fhould not have more than two or three fruit ieft upon a branch where it is ftrong, and but one on thofe which are very weak.

You muft now look carefully over your Vines, and fop fuch thoots as have fruit on them at the fecond or third joint beyond the fruit, and train the branches clofe to the wall in a regular order; but fich thoots as are defigned for bearing the fucceeding year, hould not be ftopped until the latter end of the next month, or the beginning of July; for when thefe are ftopped too foon, the lower buds often puh out weak thoots, which is a great prejudice to them. At the fame time you muft rub off all weak trailing branches, clofe to the places where they are produced; for if thefe are fuffered to remain, they will occafion a great confufion of branches, whereby the fruit will be greatly retaided in their growth, and the fhoots for bearing the following year, will be greatly weakened. If this be duly obferved, there will never be a neceffity for diverting the hoots of their leaves, to let the air and fun to 


\section{May. The Gardeners Kalendar. I5}

the fruit, as is by fome unfiiful perfons too often practifed, to the injury both of the fruit and branches. For the fruit always require to be fcreened by fome leaves, otherwife the fun and air will harden, and, infead of accelerating, will retard their ripening; and the fhoots require their leaves to infipire and perfipire, whereby they difcharge the fuperfluous moilture.

In moint weather you muft look carefully after fnails, efpecially in the evenings and mornings, or after warm fhowers, when they will come from behind wail trees, and ont of their places of thelter, fo may be eafily taken: for thefe are great enemies to choice fruit, but efpecially to Peaches, Nectarines, and Apricots.

If the feafon thould prove dry, you muft not forget to refrefh all fuch trees as have been lately planted, with water; in doing of which, it will be proper to fprinkle the water over all their branches, which will be of great fervice to them in walhing off duft and filth, which their leaves may have contracted; and open the pores of the fhoots, which in very dry weather are many times almoft clofed, whereby the trees fuffer greatly; nor is the water, when poured to the root only, capable of relieving them when in this condition; this is

$$
\text { L } 4 \text { one }
$$




\section{52 The Gardeners Kalendar. May.}

one reafon, why rain is much more effectual than artificial watering: but thefe waterings fhould be always performed in the evening, after the heat of the day is over, that the water may have time to foak down to the roots, and the moifture may be dried off from the leaves by the morning fun; for when this is done in the morning, the heat of the fun coming upon the trees foon after, the leaves are frequently fcalded thereby, the fpherical drops of water, which remain on their furface, caufing the rays of the fun to converge to a focus meeting in a point.

Keep the borders about your fruit trees clear from weeds, and alfo from all ftrong-growing plants, which will exhauft the goodnefs of the foil, to the great prejudice of your trees; and this thould alfo be carefully obferved in the nurfery, for the fame reafon.

A bout the middle of this month you muft look over your vineyard Grapes, taking off all dangling thonts, and ftop thofe which have fruit upon them, which muft now be faftened to the ftakes, to prevent their being broken by winds; but the thoots for the next year's bearing mult be trained upright to the ftakes, and not ftopped until the end of the next month, or 
May. The Gardeners Kalendar. $\quad$ I53 the beginning of July, for the reafons beforo given for the wall Vines.

You muft alfo obferve to keep the ground in the vineyard very clear from weeds, and fuffer no fort of plants whatever to grow between the rows of Vines; for nothing can be more prejudicial, than permitting this in vineyards.

The Vines, and other fruit trees, which are againft hot walls, hould now have a large fhare of air, whenever the weather will permit, otherwife their hoots will be drawn too weak, and the trees thereby rendered fhort in their duration: the Apricots, Cherries, and other ftone fruit trees againft thefe walls, fhould be frequently watered; for as the rain will be excluded from both the trees and borders by the covers, fo this munt be fupplied with water, which hould be fprinkled all over the branches carefully in the evening, for the reafons before given.

Toward the latter end of this month you mould break off the clay from thofe trees which were grafted in the fpring, and loofen their bandages; otherwife they will be fubject to break off where they are pinched with the bafs, in windy weather. 


\section{I54 The Gardeners Kalendar. May.}

Fruits in Prime, or yet lafing.

Pears; L'Amozelle, or Lord Cheyne's Green, Bergamot de Paque, and Beffy de Chaumontelle, from efpalier trees, where they have been well preferved, alfo Paikinfon's Warden, and the Cadillac, for baking.

Apples; Golden Ruffet, Stone Pippin, John Apple, Winter Ruffet, Pomme d'Api, Oaken Pin, Pile's Ruffet, and fometimes the Nongareil, when they have been carefully preferved.

Cherries; the May and May Duke; and, in a warm foil, fome fcarlet Strawberries; toward the end of the month in very warm fituations, Goofeberries, and green Curiants for tarts; and in the forcing frame, Mafculine Apricots, Nutmeg Peaches, Cherries, Strawberries, with fome other early fruits.

\section{Work to be done in the NURSERY.}

In this month you munt carefully keep the ground hoed between your young trees; for nothing is more injurious to them, than to fuffer weeds, or any other plants, to grow amongt them, for thefe rob the trees of their nourinhment; and if weeds are permitted to get frength 


\section{May. The Gardeners Kalendar. $\quad$ I 55}

in this month, it will be much greater trouble to root them out afterwards. Nor hold you plant any kitchen herbs between your rows of trees (as is by fome unikilful and covetous perfons practifed); for thefe will draw all the nourithment from the "itrees, and render them weak and unhealthy.

The middle of this month you muft look over your grafts, and take off the loam from them; and thofe which were faftened with bandages, fhould now be untied; otherwife the graft will be pinched at the ftock, and be in danger of breaking off with the wind; and where there are any hoots put out from the ftocks below the graft, they fhould be rubbed off, otherwife they would rob the grafts of their nourifhment. You fhould alfo look over your trees, which were budded the laft feafon; and where you obferve the leaves to curl up by being infefted with infects, you hould take them off, otherwife they will fpoil the upright fhoot; and if there are any fhoots produced from the focks, thefe fhould alfo be intirely rubbed off, for the reafon before given.

Where your buds or grafts have made vigorous thoots, it will be proper to fupport them with fhort fakes, otherwire they will be in danger of being broken out of the ftocks by ftrong

winds, 


\section{I5 The Gardeners Kalendar. May.}

winds, efpecially thofe which ar in expofed fituations.

Your feed-beds of young plants muit now be carefully weeded, and in dry weather frequently refrefhed with water; otherwife they will be fo ftinted, as not to make any progrefs the fame feafon. Your young plants of $\mathrm{Ce}$ dars, Firs, Pines, Cyprefs, Bay, Arbutus, Juniper, Holly, Ẽc. muft now be often refrefhed with water; this Ihould not be given to them in large quantities, but rather often and moderate. You muit alfo obferve to made them from the fun in the middle of the day, to which if they are too much expofed, while young, it is often very deftructive to them; as are alfo the drying winds, which frequently reign in the fpring, and are very often the deftruction of numbers of thefe plants, by drying their tender ftems.

You may now make layers of the Double and Single Virgins Bower, and of other climbing plants; for many of thefe will not put out roots from the old woody thoots, but the tender branches of the fame year's growth, laid down in this month, or the beginning of the next, will take root very well. You may alfo lay down Alaternufes, Phillyreas, and fome other 


\section{May. The Gardeners Kabendar. $\quad 157$}

evergreen trees, which alfo take root better from young thoots, than from older branches.

If this month fhould prove very dry, you muft continue to water fuch Evergreens, and other young trees, as were removed the laft month, otherwife they will fuffer greatly. But you hould do this with caution; for many people deftroy their trees by over-watering them. You hould alfo renew the mulch round the trees, to prevent the fun and wind from drying the ground. Where the roots of newplanted trees are carefully mulched, if they have water once a week in dry weather, it will be fufficient.

Work to be done in the FLOWER-GARDEN.

The beginning of this month you hould take up your choice Hyacinth roots, which are paft flowering, and lay them horizontally in a bed of earth to ripen, leaving their leaves and ftems out of the ground to decay, in the manner directed in the GARDENERS DICTIONART, under the article Hyacinth.

Shade your choice Tulips, Ranunculufes, Anemonies, and other curious flowers now blowing, from the fun, during the heat of the day; which will continue them in beauty much 
I $5^{8}$ The Gardeners Kalendar. May. longer than if they are fully expored to the weather.

Take up the roots of the Saffron and the other forts of autumnal Crocus, as alfo Colchicums, autumnal Amaryllis, Hæmanthus, Perfian Cyclamen, and Pancratium, whofe leaves are by this time decayed, and fpread them on mats in the thade to dry; after which fome of the forts may be kept in bags until July, when it will be a proper feafon for planting them again. But the Perfian Cyclamen hould not be kept long out of the ground, and thofe other roots hould be guarded from rats and mice, otherwife they will deftroy them.

This is alfo a good feafon for to tranfplant fuch of the bulbous and tuberofe-rooted flowers as blow in autumn, which hould be done wihen their leaves are decayed; as the autumnal Cyclamen or Sow-bread, Starry Autumnal Hyacinth, Ecc. provided their leaves are decayed, otherwife this hould be deferred a little longer.

Clean the borders of your flower-garden from weeds, which, if permitted to grow at this feafon, will be more difficult to deftroy and caufe a deal of trouble to extirpate afterwards.

A bout the middle of this month, if the feafun proves favourable, you may plant out your 


\section{May. The Gardeners Kabendar. $\quad$ I59}

hardy annuals, fuch as Marvel of Peru, Sweet Sultan, China Starwort, Sweet Refeda, called Mignonette d'Egypt, French and Affrican Marigolds, common Female Balfamine, Capficum, Brown Jolly or Egg plant, Zinnia, Foreign Thorn Apple, double China Pink, fpiked Amaranths, and feveral other forts; which, if artfully difpofed, will afford an agreeable pleafure, after the beauty of the fpring is paft : but thefe plants fhould be thoroughly inured to the open air, before they' are tranfplanted out of the hot-bed.

Sow dwarf annual flower-feeds in patches upon the borders of the flower-garden, where they are intended to remain; as Candy Tuft, Venus Looking-glafs, Venus Navelwort, Dwarf Annual Stocks, Dwarf Lychnis, Lobel's Catchfly, Convolvulus Minor, Snails and Caterpillars, with many other kinds; thefe will fucceed thofe which were fown the former month, and hereby the borders may be kept in beauty through the feafon: and alfo plant the feveral kinds of Lupine, Sweet-fcented Peas, Tangier, Peas, Seeds of the Indi n Nafturtium, Large Convolvulus, and other climbing annual plants, where they may have room to fpread, and have fome fupport; in which places they will flower, 
I60 The Gardeners Kalendar. May. and make a beautiful appearance late in the autumn.

Tranfplant fuch biennial and perennial flow: ers as were fown in the flower-nurfery in March, if they are grown large enough for the purpofe, into beds of frefh earth in the nurfery, where they may remain till the latter end of September, or the beginning of October, when they mult be removed into the borders of the flower-garden: of thefe forts are Canterbury Bells, French Honeyfuckles, Sweet-Williams, Pinks, Columbines, Fox-gloves, Greek Valerian, Hollyhocks, with many others.

Tie up the fpindles of Carnations, divefting them of all fide pods, which, if permitted to remain on, would weaken the top and principal flower; and alfo put down ftakes to faften the ftems of all flowers which are to blow, otherwife they will be in danger of being broken by the winds.

In this month, if the young flower-ftalks of the feveral forts of Lychnidea, the late flowering After or Starwort with narrow leaves, and the Double fcarlet Lychnis, are cut off and planted in a hady border, they will take root very well; and this is the beft method of propagating feveral of thefe perennial flowers. The cuttings of the Starwort will make good plants, 
May: The Gardeners Kalendar. I6 plants, and produce flowers the following autumn.

Make a freh hot-bed for your Amararthufes, Double-ftriped Balfamine, and other tender exotick annuals, and put them into large pots of good earth, placing them upon the hot-bed, and fill up the interftices with earth; if care be taken of them, at this time, they will be very ftrong and beautiful.

Your Auriculas which are now paft flowering, fhould be removed into a ghady fituation (but not under the droppings of trees, which will rot them); in which place they muft remain, until the heat of fummer is over.

Tranfplant Stock-Gilliflowers, Wall-Lowers, Seedling Pinks, Carnations, and other perennial, feedling, fibrous-rooted flowers; and fow fome feeds of annual, fcarlet, and purple Stock-gilliflowers, which will produce thorter plants, and many times will endure the cold better than thofe which are fown carlier, and are larger.

Toward the latter end of the month you may take up fuch of the early blowing Tulip roots, whofe leaves are decayed; alfo Spring Crocus, Snow-drops, aed fome of the forward Anemonies, if their leaves are decayę ; after which, thofe roots which are interded to 


\section{The Gardeners Kalendar. May.}

be taken up, thould not be permitted to remain long in the ground.

Plant fome Tuberofe roots upon a moderate hot-bed, to fucceed thofe planted in March and April; by which method, you may continue a fucceffion of this fragant flower until the end of October in beauty.

Your pots or tubs of feedling Irifes, Narciffules; Tulips, and other bulbous-rooted flowers, fhould be removed into a hady fituation the beginning of this month (if it was not done in April), where they muft remain until autumn; nothing being more injurious to thefe young roots, than to be expofed to the violence of the fun in fummer, efpecially thofe which are in tubs or pots; thofe which are in beds, thould be alfo maded with mats in the heat of the day.

Toward the end of this month, the leaves of the Guernfey and Belledonna Lillies will decay, at which time their roots thould be tranfplanted; and, at this feafon, the roots may be fafely tranfported, becaufe they may be kept two months out of the ground without injury.

The young plants of Scabioufes, Sweet Sultan, Indian Pink, Chryfanthemum, Buphthal. mum, and Oriental Perficaria, may now be planted 


\section{May. The Gardeners Kalendar. $\quad \mathbf{I}_{3}$}

planted into the beds or borders of the flowergarden, where they will make a beautiful appearance when they flower. But this work fhould be done in moift weather, and the plants fhould be fiaded until they have taken new root.

Place your pots of choice Carnations upon the ftage where they are to flower, to protect them from vermin, which will otherwife infert them, and will harbour about the pots, fo as not to be eafily deftroyed.

The grafs walks and lawns in the pleafuregarden fhould now be duly mowed and rolled, otherwife the grafs will foon grow rank and unfightly; and where Daifies, Plantain, or other weeds are mixed with the grafs, they hould be weeded out, otherwife many of their feeds will ripen and fcatter, and thereby multiply their fpecies, which will overpower the grafs, and render the verdure lefs agreeable.

The gravel walks thould now be kept clean; for a little neglect, at this feafon, will render it troublefome to bring them into good order 2gain.

\section{Plants now in Flower.}

Late-blowing Tulips, Anemonies, Ranunculufes, Pinks of feveral forts, White and Yel- 
154 The Gardeners Kalendar. May. lew Afphodel, Lily of the Valley, Daifies, fome forts of Chryfanthemum, Thrift, Red and White Garden Valerian, Cyanus Major, Thalietrums of feveral kinds, Sage, Rofemary, Moth-Mullein, Double Catchlly, Veronica of three or four kinds, London Pride, Spanifh Figwort, Geraniums of feveral kinds, Ciftus three or four forts, Turky Perennial Poppy, Fiery Lily, Pionies of feveral forts, Columbines, Monkhood, Fraxinella with red and white flowers, Yellow Moly, Homer's Moly, Stock-gillifowers, Wall-flowers, Orobus Vicix foliis, Tragacantha, Leopard's-bane, Solomon's Seal, Yellow Afphodel Lily, Hyacinth of Peru, Dragon, Biffort, Rhapontic, Ladies Mantle, Tuberofe Irifes, Dwarf Annual Stock, Feathered Hyacinth, Ladies Slipper, Welh Poppy, Birds-eye, Yellow Violet, Orchifes, Hearts-eafe, Double White Narcifus; Pulfatilla, Double Rockets, Corn-flags, Englith Hyacinth or Hare Bells, Yellow and Pompony Martagons, two forts of Starry Hyacinths, Blue Grape Hyacinth, Bulbous Iris, Flag-leaved Iris of Several forts, Tradefcant's Spiderwort, Savoy Spiderwort, Double Purpleand large Blue Perriwincles, Peach-leaved and Nettie-leaved BellAlower, Maudlin, Birthwort, Afarabacca, Catsfoot, Noli me tangere, Great Gentian, Honey- 


\section{May. The Gardeners Kalendar. $\quad 165$}

wort, Mandrake, Greater Navelwort, Spotted Lungwort, Hedyfarum Clypeatum flore albo \& rubro, Lychindea Virginiana, Greek Valerian with white and blue flowers, Double white and red Batchelor's Button, Double white Mountain Ranunculus, Double Ragged Robin, Double Feverfew, Foxglove of three or four fort, Buphthalmums, Sea Ragwort, Double Saxifrage, Double Ladies Smock, Borageleaved Verbafcum, Spanifh Toad-flax, Spurges of feveral kinds, Grafs-leaved Ranunculas, Honefty or Satten flower, Upight Speedwcll, Yellow Eaftern Buglofs, Garden Buglofs, Onobrychis, Scabioufes, Antirrhinum or Snapdragon, Eaftern Veronica with fine cut leaves, Globularia, Dwarf Blue Ornithogalum, Perennial Adonis, Perennial Omphalodes, Portugal Dead Nettle with large flowers, Borage from Conftantinople, Claytonia, Italian Arum, Yellow Alyfion of Crete, Large Yellow Avens, SeaCabbage, Double Crowfoot, Annual Adonis with red and yellow flowers, Afarina, Meadia, Dodartia, Vulneraria, Daifes of feveral colours, Matted Pink, Sea Pink, Androface, with fome others of lefs note. 


\section{The Gardeners Kalendar. M
Hardy Trees and Sbrubs now in Flower.}

Phlomis or Jerufalem Sage, two or three forts, Yellow Jafmine, Colutea Scorpoides, Oriental Colutea with bloody flowers, Lilacs feveral forts, Early White, Italian, and common Honeyfuckles, Gelder Rofe, White Thorn, Flowering Afh, Bladder Nut, Cinnamon Rofe, Monthly Rofe, Damafk Rofe, Burnet-leaved Rofe, Scotch Rofe, Apple-bearing Rofe, Horfe Cheftnut, Three-thorned Acacia, Laburnums, Cytifus fecundus clufii ; Lote or Nettle tree, Bladder Sena, Double-flowering Dwarf Almond, Cockfpur Hawthorn, Doubleflowering Hawthorn, Cinquefoil Shrub, Bird Cherry, Purtugal Laurel, Scarlet Horfe Cheftnut, Perfumed Cherry, Ciftus of feveral furts, Mallow tree, Arbor Judæ, Shrubby Moontreefoil, Sea Buckthorn, Spiræa Salicis folio, Spiræa Opuli folio, Spiræa Hyperici folio, Dwarf Medlar, Amelanchier, Candleberry Myrtle, Chamrelæa tricoccos, Chrift's Thorn, Piftachia Nut, Pyracantha, Rofemary, Myrtle-leaved Sumach, Toxicodendron or Poifon Af, Virginia Service with Arbutus leaves, Wild Service or Quickbeam, Aria Theophrafti, True Service, Maple-leaved Service, Double-flowering Cherry, Purple Mountain Shrubby Reft Harrow, 
May. The Gardeners Kalendar. $\quad 167$ Hairy Cytifus, Viburnum, Dogwood, Euonymus, Privet, Black Haw, Plane tree, Common Montpelier and Ah-leaved Maple, Flowering Afh, Coronilla Cretica, Common Broom, Shrubby Dyers Weed, Tartarian Robinia, called Caragana, Bafteria, Diervilla, Clematis's of two or three forts, Hardy American Annona, Button tree, Pifhamin, Dwarf Tartarian Cytifus, Stechas Purpurea, with fome others.

MEDICINAL PLANTS wobich may nose be gatbered for Ufe.

Bears-breech, Sorrel, Wood Sorrel, Ladies Mantle, Lily of the Valley, Pimpernel, Brooklime, Water-crefs, Ground Ivy, Reft Harrow, Rofemary flowers, Dead Nettle, Archangel, Clivers, Fumitory, Columbine, Herb Paris, Silverweed or wild Tanfey, Stonecrop, Woodrcof, Mandrake leaves, Moufe-ear, Daify, Dandelion, Betony, Groundfel, Mercury, Adderstongue, Boragc, Buglors, Bugule, Woad, Poplar leaves, Shepherd's Purfe, Ladies Smock, Piony flowers, Avens, Scurvy-grafs, Chervil, Comfrey, Plantain, Teafle, Navelwort, Horfetail, Croffwort, Greater Blue-bottle, Mufk Cranes-bill, Bean flowers, Burnet, Spotted Lungwort.

$$
\mathrm{M}_{4} \text { Work }
$$




\section{Work io be done in the GREEN-HOUSE and STOVE.}

Abcut the middle or latter end of this month, if the weather be fettled and the nights warm, you hould bring forth your Orange trees, and (if poffible) take the advantage of a mower of rain for this work, which will wain the duft from the furfaces of their leaves, and greatly refrefh them : you fhould at this time (if you have not before done it) take out the earth from the top of the pois or tubs, and fill them up with frem rich earth, which will greatly encourage their fowering, and caufe them to make vigorous fhoots; and if their frems have not been cieaned the preceding month, it hould now be done; this is only meant for fuch trees as are not removed out of the tubs or pots the iame year.

You may now inarch Oranges, Jafmines, Pomegranaies, and other tender exotick trees, cbferving to place them where they may be ineltered from frong winds, which would difplace the inarched hoots, if they were toa much expofed theieto.

Malse 
May. The Gardeners Kalendar. $\quad 169$

Make layers of Myrtles, Pomegranates, Jafmines, Paffion flowers, Capers, and other tender fhrubs, obferving to lay fome mulch over them, and fupply them fiequently with water, which will greatly facilitate their rooting; but it muit not be given them in too great quantities.

In the middle of the day, if the weather prove hot, you fhould thade the glaffes of the ftove and the hot-beds, where your choice exotick plants are placed, and let them have free air, in proportion to the warmth of the feafon; and fuch of your exotick plants as want hifting, fhould now be removed, and fome of them placed in larger pots, giving them freh earth, and then plunge them into the hot-bed again, obferving to fhade the glafies until they have taken frefh root.

Toward the latter end of the month plant cuttings of Mefembryanthemums, Sedums, Cotyledons, Cereufes, Euphorbiumş, and other fucculent plants, laying them in a diry mady place a week or fortnight, according as they are more or lefs fucculent, before they are planted, that the wounded part may be heaied over, otherwife they are fubject to rot; and when they are planted, they hould be placed (fuch cif them as are hardy) in a fhady fituation 
170 The Gardeners Kalendar. May. fituation for a fortnight or more; but thofe which are tender muft be planted in pots, and plunged into a moderate hot-bed of tanners bark, obferving to thade the glaffes in the heat of the day, and refreh them with water as they may require: the hardy forts may alfo be planted in a bed of light earth, where, if they are fcreened with mats, they will freely take root.

Cleanfe the leaves of Aloes, and other tender exotick plants, from duft and filth, which they have contracted in the houfe during the winter, and cut off all decayed leaves of thofe plants, for now the wounds given to them will foon heal : this is alfo a proper time to cut off the heads of thofe forts of Aloes which grow with large ftems, and feldom afford off-fets ; fo that there is no other method to propagate them, than by taking off their heads for planting, and thereby caufing their ftems to fend forth a freh thoot or two; but you muft obferve to leave three or four good leaves upon the ftem to draw the fap, otherwife the ftem will decay without producing any new head; you muft alfo weep them in the houfe, and not expofe them abroad to the wet, until the wounds are perfectly healed; and if you plunge them into a moderate hot-bed, it will facilitate their thooting. 


\section{May. The Gardeners Kalendar. I $7 \mathbf{I}$}

Turn over your heaps of mpoft, to prevent weeds growing on them; and the oftener this is done, the better will they be mixed, and fweetened for ufe.

Bring out all your hardy exotick plants, fuch as Ciftufes, Geraniums, Phylica, Celaftrus, Sorrel tree, Amber tree, Arctotis's, Hermannias, Yellow Indian and Spanin Jafmines, Polygala frutefcens, Hypericum from Minorca, Fabagos, Rhufs, Oleanders, African Scabioufes, Phlomis, Spring Cyclamen, Lentifcufes, with feveral other forts, which will now bear the open air ; but you fhould obferve to place them in a thady fituation for a fortnight; for if they are immediately expofed to the full fun, it will change their leaves to a brown colour, and caufe the plants to appear very unfightly.

Thofe exotick plants which are to be continued longer in the houfe, muft now be brought forward to the windows, that they may have a great thare of frefh air (efpecially if the feafon be warm); otherwife they will draw very weak, and change to a pale languid colour; and where the plants have been drawn too weak to bear the fun, if the glaffes are fhaded in the heat of the day, it will be better than to expofe them too much to the fun until they are more hardened. You hould alfo ob- 


\section{The Gardeners Kalendar. May.}

ferve to cleanfe their leaves and hoots from infeet's, which are very apt to infert them in the houfe, efpecially where the plants are much crowded; and if thefe are not wahed off in time, they will greatly injure the plants, efpecially the Coffee tree, which is now flowering, and is frequently infefted with thefe fmall vermin, which at firft appear like duft upon the leaves, which fhould be immediately wafhed eff, otherwife they will fpread, in a hort time, over molt of the plants.

If the feafon fhould prove cool, and the bark-bed, in which your Ananas are placed, Arould abate of its heat, you muft ftir it up again, and mix a little new bark with it, which will renew the heat, and be of great fervice in forwarding the fruit: it will alfo be of great fervice to the young Anana plants, which are defigned for fruiting the next year; for if the tan-beds are kept in a kindly heat all the fummer, and a fufficient thare of air admitted to the plants, they will become ftrong and healthy, fo capable of producing large fruit. And at this time you thould thift thofe plants which are to produce fruit the fucceeding year, if it vas not done the laft month, into larger pots, that their roots may have room to fpread. But 


\section{May. Tbe Gardeners Kalendar. 173}

you muft be careful not to put them in pots too large, for this will prevent their growth.

Plonts in Flower in the GREEN-HOUS: and S T O V E.

Geraniums of feveral forts, Spanih Teucium with broad and narrow leaves, Aretotis of feveral forts, Othonna with hoary divided leaves, Canary Chryfanthemum, Hermannia of feveral forts, Elichryfums, Canary Broom, Ciftus Ladanifera, Ilex-leaved Jafmine, Heliotropium Scorodoniæ folio, Polygala Africana, IEthiopian Calla with a white flower, Convolvulus Canarienfis, Ficoidefes of feveral forts, Broad-leaved African Afphodel, African Tree Scabious, Shrubby African Sage, with blue and iron-coloured flowers, Iatropha with multifid leaves, and another with leaves like Stavefacre, Lotus argentea Cretica, Turnera with Mrubby ftalks, and an elm leaf, and another with narrow-pointed leaves, Amaryllis, Crinum, Pancratium, Jujubes, Myrtles, Royenia, Myrfine, Upright filvery Convolvulus, Bafella, Arabian Jafmine, Indian Fig, Indian flowering Reed, Bauhinias, Acacias, Apocynums, Phlo. mifes, Melianthus two forts, Wationia, Ixia, Cunonia, Sifyrinchium, Coral tree, Malpighia, 
174 The Gardeners Kalendar. May. Papaya, Caffia, Dumb Cane, Rauvolfia, Purple American Helleborine, Kempferia, Waltheria, Ceftrum, Lyciums of feveral forts, Celaftrus, Clutia, Small creeping Cereus, Antholiza, three forts of Diofma, Euphorbiums, Hæmanthus with fpotted italks, Coffee tree, Melocactus Minor, Piercea, Dwarf Yellow An. thericum, Craffulas, Shrubby African Foxlove, Paffion flowers, Solanums of feveral forts, two forts of African Marigolds, Tree Candy Tuft, Atraphaxis, Evergreen climbing Birthwort, Tree Wormwood, Kiggelaria, Cotyledons, Fabagos, Pforalea of three kinds, Lotus with black flowers, Climbing Arum with perforated leaves, Shrubby Peruvian Heliotrope, Pafferina, Chironia, Shrubby African Lavatera, Blue Starwort of the Cape of Good Hope, Oranges, Lemons, Citrons, Limes, and fome forts of Aloes.

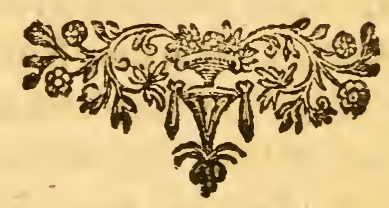




\section{The Gardeners.Kalendar. June.}

two or three, which is what every perfon, who is acquainted with the London gardeners practice, muft be convinced of.

The Cauliflower plants which were fown the laft month for winter ufe, will be fit to tranfplant towards the end of this month; when they mould be pricked out into beds of rich earth, obferving to thade them until they have taken root, and be fure to water them duly, in dry weather, otherwife they are apt to fint and be inferted with infects.

Hoe and clean Carrots, Parfneps, Onions, Leeks, Beets, and all other late crops; for if the weeds are permitted to grow at this feafon, many of them will hed their feeds in a thort time, and become troublefome hereafter, and the larger forts will overbear the crops, and draw them up weak, to their great prejudice.

You may yet make lips or cuttings of Sage, Rofemary, Stæchas, Lavender, Hyfiop, Winter Savory, and other aromatick plants; though it had been better if done earlier in the year, becaufe this month often proves hot and dry, and the plants, having long and tender fhoots, are in greater danger of mifcarrying. Thefe cuttings hould have a fmall part of the former year's moot to them, which is the furent method to have them fucceed. 
June. The Gardeners Kalendar.

Plant out young plants of all forts of fweet herbs which were fown in March; as Thyme, Hyffop, Sweet-marjoram, Ėc. and alfo Clary, Burnet, Sorrel, Marigolds, and many other forts, obferving to allow them room enough to fpread, which will render them much ftronger than thofe which remain in the feedbeds; but thefe muft be duly watered, and the fweet herbs which are planted in beds, hould be fcreened from the fun, until they have taken root.

Clear and hoe the ground whereon your earlieft Cauliflowers grew, which will be all gone by the middle or latter end of this month. And if you have ridges of Cucumbers or Melons made between the rows of Cauliflowers, (as is the practice of the London gardeners) you fhould dig all the ground between the ridges of Cucumbers, and lay out the Vines in regular order; this will not only loofen the ground for the roots of the plants, but alfo deftroy the weeds, and render the furface of the ground wholfomer for the Vines to lie upon: but in doing of this, you fhould be very careful not to bruife of breals the Vines, which would be very injurious to them; and (if pofiible) let it be done in moift weather. 


\section{The Gardeners Kalendar. June.}

Now you thould fill up the alleys between your laft ridges of Melons: if this is done with loam and very rotten cow dung mixed, and the whole troden down very clofe, the plants will not require any water afterwards; for if their roots have depth enough of ftrong land, they will produce a much greater crop of fruit, than thofe planted on thallow beds, which muft be watered, and the fruit will be much better flavoured.

Sow Turneps upon a moift fpot of ground, when there is a profpect of rain in a little time, for moifture will bring up the plants in a few days; but in dry weather the feeds will remain in the ground, and not vegetate; befides, if the plants come up, and the weather continues very hot and dry, the fly will take them, and deftroy them in a hort time.

In the beginning of the month you may fow fome Broccoli feed for the fecond crop, and Finnochia, to fucceed that which was fown in the middle of the former month; for in very hot weather this plant will not remain good above a fortnight, before it will run to reed ; fo that if it be not often fown, there will be a want to fupply the kitchen.

Tranfplant Celery into fhallow trenches for blanching, allowing about four or five inches 
June. The Gardeners Kalendar. 179 inches fpace between each plant in the rows; and make the trenches three feet afunder, that there may be room enough between them to earth up the plants, when they are full grown.

Plant the laft crop of Kidney Beans to fucceed thofe which were planted in May; and fow brown, Dutch, and common Cabbage Lettuces, for a late crop; tranfplant fuch Lettuces as were fown the beginning of May, obferving to place them in a hady fituation, but not under trees, nor too near walls or other buildings, which will draw them up weak, and prevent their cabbaging.

Tranfplant Endive in an open moirt fpot of ground for blanching, allowing the plants a foot diftance each way, that they may have room to fpread; and the latter end of this month fow fome Endive feed for the full crop.

Continue to fow fmall fallet herbs every three or four days; fuch as Creffes, Muftard, Turnep, Rape, Radifh, छ ${ }^{2}$. for, at this feafon, they will foon grow too large for ufe.

You muft now thin the Finnochia plants, which were fown the former month, obferving to allow them room enough to grow, otherwife they will draw up weak, and never fwell at bottom; but the plants which are taken out 
180 The Gardeners Kalendar. Jüne.

mould not be tranfplanted, for they rarely are good for any thing, being very fubject to run to feed, before they arrive to any fize.

The Broccoli which was fown in May, fhould be now pricked out into beds at about three inches afunder, where they will grow ftrong, in order for planting out the next month; for where they are fuffered to grow in the feed-bed too long, they draw up weak, and never produce fo good heads as thofe which are thort and ftrong in the ftems.

Weed and thin the plants in your Cucumber holes which were fown for pickling, obferving to leave but four of the ftrongeft and bof fituated plants in each hole; and at the fame time earth up their thanks, which will greatly ftrengthen them; and give them fome water to fettle the earth about them.

Plant out Cardoons for good, allowing each plant four feet of room, otherwife they cannot be earthed up fo high as they will require when they are fully grown.

In dry weather, gather feeds of all thofe forts that are ripe, fpreading them upon mats or cloth to dry, before they are rubbed or beaten out of their hufks or pods.

Gather herbs for drying of fuch forts as are now in flower, viz. Carduus Benedictus, 
June. The Gardeners Kalendar. I8 Mint, Lavender, Clary, Sage, Marigold flowers, Ecc. and hang them up in a dry thady place, where they may dry leifurely, which will render them better for any purpofe, than if they were dried in the fun; and this is the beft feafon for diftilling moft forts of herbs, which being now in flower, are much better than when they are fuffered to ftand longer.

Your Melon plants, that are growing upon beds which are not deeply earthed, and are now fetting of their fruit, fhould be thaded in the heat of the day with mats, if the weather hould prove very warm, otherwife their fruit will drop; and you thould be careful not to give them too much water, which is often injurious to them. The beft method is, to water the alleys between the beds, which will foak through to the roots of the plants, and thereby fupply them with moifure; and there will Be no danger of the plants rotting by this method, as the water will not come near their ftems.

Gather up fnails in the morning and evening, and after thowers of rain, at which times they will come abroad from their holes and places of harbour, fo that they are eafily deforoyed. 


\section{I8 2 The Gardeners Kalendar. June.}

The weeds which now come up in moft gardens are, Wild Orach, Nighthade, Thornapple, Groundfel, Sow-thiftles, Shepherd'spurfe, Dandelion, Pimpernel, छcc. which, if permitted to grow, will many of them foon Thed their feeds, whereby the ground will be plentifully focked with them, and by their growth among crops, will foon get the better of them, and fpoil whatever plants are near them.

You may now tranfplant Leeks out of the feed-beds into the places where they are to remain, obferving to water them until they have taken root: this is often practifed in fmall gardens, where any early crop of Beans or Cauliflowers has heen produced on the fame ground, before the Leeks are planted on it.

The young Afparagus-beds, which were planted in March, fhould be kept very clean from weeds, which, if permitted to grow, will foon weaken the roots, and fometimes deftroy them. For wherever a large weed happens to ftand near any of the Afparagus plants, their roots will infinuate themfelves between thofe of the Afparagus ; fo that in pulling up the weeds, the roots of Afparagus are many times drawn cut of the ground with them. 


\section{June. The Gardeners Kalendar. $\quad \mathbf{I}_{3}$}

Products of the KITCHEN-GARDEN.

Cauliflowers in plenty, Cabbages, young Carrots, Beans, Peas, Artichokes, Afparagus, Turneps, Cucumbers, Melons, Kidney Beans, Cabbage Lettuces of various kinds; all forts of young fallet herbs; as Chervil, Creffes, Muftard, Rape, Raddih, Corn fallet, Purflane, fuckers of Artichokes, Tanfey, Mint, Baum, and other aromatick pot-herbs, fome late Raddifhes, Ecc. fome early Finnochia, large rooted Parney, fome Celery and Endive where they were fown very early, with other kinds.

All forts of fweet herbs, as Lavender, Thyme, Winter Savory, Hyffop, Marum, Maftich, Stœchas, Eंc. as alfo Sage, Rofemary, Origanum, Pennyroyal, Parßley, Sorrel, Burnet, Buglofs, Borage for cool tankards, with many kinds of medicinal or culinary plants.

Work to be done in the FRUIT-GARDEN.

Begin to inoculate ftone fruits toward the end of the month, doing it in an evening, or in cloudy weather: the firft fort which is fit to bud, is the Mafculine Apricot, afterward all the other forts of Apricots, then the Peaches and

$$
\mathrm{N}_{4}
$$

Neqa- 


\section{The Gardeners Kalendar. June.}

Nectarines, Cherries, Plums, $\bigotimes^{2} c$. obferving to take of each fort according to their times of ripening their fruits.

You mult now look over your wall and efpalier trees again, and rub off all foreright, ill-placed, or luxuriant branches, and train the others regularly at equal diftances to the wall or efpalier; but be not too officious with the knife at this feafon, neither fuffer any of the leaves to be pulled from the branches, unlefs they are diftempered; for the pulling off the leaves, will expofe the fruit too much to the fun in the day, and cold in the night, and thereby check their growth ; befides, by taking off the leaves too foon, the buds which are formed at the foot-italks of thofe leaves will be greatly injured thereby.

Where Peaches and Nectarines have been left too clofe together when they were thinned, they hould now be taken off, being careful not to fuffer two or more fruits to grow nearer than five or fix inches apart, which will greatly improve the fruit, and ftrengthen the tree for the fucceeding year.

Look carefully after fnails and other vermin which infert your choice fruit, and, if not timely prevented, will fpoil it in a Mort time at this featon. 


\section{June. The Gardeners Kalendar. $\quad \mathbf{1}_{5}$}

In dry weather water fuch trees as were tranfplanted the former feafon, obferving to preferve mulch upon the furface of the ground about their roots, to prevent their being dried by the fun and wind; and faften thofe rhoots which have been produced, either to the wall or efpalier, in the order they hould grow; for if they are permitted to grow loofe, they will be in danger of being broken by winds, $\mathcal{E} c$.

Obferve to keep the ground about your trees clear from weeds, and all other plants; for if they are fuffered to grow, they will exhauft the nourifhment of the ground, to the great injury of the trees, and to the fruits which fuch trees produce; which will not be near fo large, nor well tafted, as thofe which are produced upon thofe trees where no plants are fuffered to grow about them: you hould alfo gently ftir up the earth of the borders about your fruit trees with a dung fork, to loofen it where it has been trodden down, by looking over and nailing of the trees: or if the foil is very ftrong, and fubject to be bound, or grow hard, this will prepare the ground to receive every nower of rain, and admit it to the roots of the trees; but this Mould be very carefully performed, fo as not to fork too deep, to dif- 


\section{I86 The Gardeners Kalendar. June.}

turb the roots of the trees, or to expole them to the fun and air.

The Vines thould now be looked over again, and the branches which are loofe muft be fa!tened to the wail ; and all fide moois, or weak trailing branches, muft be intirely taken off, that the fruit may enjoy the benefit of the fun and air, which is abfolutely neceffary to promote their growth; but this is often negleeted in many gardens, and the branches permitted to hang from the wall, and intangle with each other; fo that when they are put in their proper polition to the wall, their leaves will be often difplaced fo as to have their back parts upward, whereby the fruit will be retarded in its growth, until they have turned their furface upward again: and it is this neglect which occafions the late ripening or ill tafte of the fruit, and alfo renders the wood foft and pithy, fo that it produces a much lefs quantity of fruit the following year.

The vineyard fhould alfo be thus managed at this feafon, faftening the thoois to the fakes in regular order, fo that each may equally have the advantage of fun and air; and keep the ground perfectly clear from all other plants or weeds, which if permitted to grow among the 
June. The Gardeners Kalendar. $\quad 187$ the Vines, would greatly prejudice them the following year.

\section{F R I T S in prime, or yet lafing.}

Strawberries of feveral forts, Currants, Goofeberries; and, from good afpected walls, Duke, Flanders-heart, White-heart, and Blackheart Cherries: Mafculine Apricot in a warm fituation, toward the end of the month; Green Goofeberries for tarts, in cold fituations; and, in the forcing-frame, Peaches, Nectarines, and Grapes; and, in the hot-houfe, Ananas or Pine Apples.

Golden Ruffet, Pile's Ruffet, Stone Pippin, Deux Ans or John Apple, Oaken Pin, and fome other Apples, where they are carefully preferved.

As alfo the black Pear of Worcefter, Lord Cheyne's Green, and Cadillac Pears.

Work to be done in the NURSERY.

You muft obferve in this month (as was directed in the former) to keep the ground between your rows of trees in the nurfery, intircly clear from weeds; for thefe are very injurious to the trees, and nothing can have a 


\section{The Gardeners Kalendar. June.}

worfe appearance, than a nurfery over-grown with weeds; therefore this caution cannot be too often repeated: obferve alfo to keep the feed-beds, in which the feeds of trees and fhrubs were fown, intirely clear from weeds; for thefe plants being young, are foon greatly injured, if not totally deftroyed bylarge weeds.

Toward the latter end of this month you muft begin to bud Apricots, and fome early Peaches and Nectarines; but in this you muft. be guided by the condition of the trees from whence the cuttings are taken; for if the feafon has proved very dry, the buds will not eafily part from the fhoot, in which cafe it will be proper to defer this work a little longer.

Obferve to renew the mulch about your new-planted trees, where it is decayed; for at this feafon, if the weather proves dry, the moifture of the earth will be exhaled, and the young fibres will foon be dried up, where this work is not carefully performed.

You may yet lay down the tender hoots of Virgin Bower, Paffion Flowers, and many other climbing plants, whofe thoots of the fame year put out roots readily when laid at this feafon; whereas if the laying of them is deferred till autumn they frequently mifarry, or will not have roots fit to take off from the ftocks under 
June. The Gardeners Kalendar. $\quad$ I 89 under two years; after thefe are layed you fhould obforve to water them in dry weather, which will greatly promote their taking root. But thefe waterings thould not be too often repeated, nor too much water given at each time, for that will rot the tender fibres as they are puhed out; therefore the beft method is to lay fome mulch on the furface of the ground after the layers are put down, to prevent the fun from drying it too fart, and then a little water will be fufficient, and the layers will more certainly take root. You may alfo make layers of feveral hardy exotick trees, which, if laid in the young wood, will many of them take root before winter: whereas when the older branches are laid down, they frequently fail; and when they do fucceed, they will be much longer before they put out roots : fo that whatever fcarce plants you have a mind to increafe, may be tried this way, fince we are not affured what plants will take root with this management.

Trim up your Evergreens, according to the ufes for which they are defigned; for if you fuffer them to grow rude in furnmer, they cannot be fo eafily reduced afterwards; befides, the ruder they grow, the more naked they will be near the ftems.

Toward. 


\section{I90 The Gardeners Kalendar. June.}

Toward the latter end of this mouth, you may prick out into beds the feedling plents of all forts of Pines, which, if carefully thaded and watered, will foon take root at this feafon; and thefe plants will be ftronger, and much better prepared to live through the following winter, than thofe which are left in the feedbeds, as their roots will be better fixed in the ground, and their ftems will alfo be horter. All the young feedling exotick trees and Thrubs murt be now taken great care of, to hade many of $\therefore \Leftrightarrow m$ from the fun in the middle of the day in 2 . hot weather, otherwife they will be in da 4 by the earth being dried too faft about th ir ; for as they are near the furface, the heat, i very warm feafons, will be too great for them where they are expofed to the full fouth fun; for when the ground is too foon dried, that will occafion often watering, whereby the tender fibres of the plants are frequently rotted; fo that by hading them, much labour in watering is faved, and the plants will thrive better.

Work to be done in the PLeasure or FlowerGARDEN.

Tranfplant annual flowers out of the hotbed, or where they were raifed, into the borders 
June. The Gardeners Kalendar. I9I of the flower garden; fuch as Capficums, Balfamines, Convolvulufes, Love Apple, Africans, French Marigolds, Amaranthufes, Indian Pinks, China Starwort, Marvel of Peru, Chryfanthemums, Tobacco, Palma Chrifti, Alkekengi, Sweet Refeda, or Mignonette d'Æ̈gypt, Stramoniums, Yellow Sultan, Cardifpermum, Zinnia of two forts, Martynia, fmall leaved Bafil, Canary Lavendar, Hibifcus of fome kinds, Ec. obferving to do it in a cloudy day, or in an evening; and give them fome water to fettle the earth to their roots.

You may now lay down your Carnations, Pinks, double Sweet Williams, and fuch other fibrous-rooted plants, as are propagated by layers, being careful to water them as foon as it is is done; but it muft be given to them very gently, otherwife it will endanger the wahing them out of the ground, or breaking them; and this watering hould be frequently repeated, which will greatly facilitate their rooting.

This is a proper feafon for taking up and tranfplanting the roots of Cyclamens, Fritillarias, Dens Canis, Saffron, Perfian Iris, Snowdrops, Winter Aconite, Spring Crocufes, and fuch other bulbous-rooted flowers, whofe leaves are decayed, fome of which do not fucced well, if their roots are kept any long time out of the 
192 The Gardeners Kalendar. June. the ground; and the Guernfey and Belladonna Lilies may now be taken up, and either tranfplanted again immediately, or if they are to be fent to any diftance, the roots may be wrapped up in wool, and this will preferve them for two months, or longer.

Cut off the fallzs of fuch flowers as have done blowing, and are decaying; and tie up fuch flowers to fticks as are yet to blow, efpecially your tall autumnal plants, which are often breken down by the wind, if they are not timely fupported with frong ftakes.

Take up your Hyacinth roots out of the beds wherein they were laid the former month to ripen, and clear them from earth and filth, laying them upon a mat in a mady place to dry; after which they may be put into drawers or boxes, where they may enjoy the free air, without which they often grow mouldy and decay.

It is now time to take up the roots of $\mathrm{Tu}$ lips, Anemonies, Ranunculures, Narciffus, Fritillarias, Crown Imperials, Tulips, and other bulbous and tuberofe-rooted flowers, whofe leaves are dećayed, and fpread them upon mats in a hady place to dry; then clean them from filth, and put them up in boxes or bags until the feafon for planting them, being careful to 
June. The Gardeners Kalendar. 193 put them out of the reach of rats and mice, otherwife they will eat them up, but efpecially the Tulip roots.

Your Carnations, which begin to break their pods, hould be opened in two or three different parts, at equal diftances, that their flowers may expand equally on every fide, otherwife they will throw their petals out only on one fide of the pods, whereby the flowers will appear very irregular: you muft alfo obferve to cover them with glaffes foon after their pods are open, to fcreen them from mointure; and, in the heat of the day, the glaffes muft be covered with paper, or Cabbage leaves, to fcreen the flowers from the heat of the fun, both which are very injurious to them; but fome very curious perfons make their covers for thefe flowers, with oiled paper, which is much better than glafs, becaufe the heat is not fo great through them, fo the flowers will not be in danger of fcorching with fuch covers as with glafs; look carefully after earwigs and ants ; for if thefe can come at the flowers, they will defiroy them in a thort time, by eating the fweet ends of the petals next the nectarium, whereby the leaves will fall out of the pods.

Tranfplant fuch forts of perennial or biennial fibrous-rooted plants as were fown the two 
194 The Gardeners Kalendar. June. former months, into nurfery-beds, where they mould be allowed room enough to grow till autumn, which is the proper feafon for planting them in the borders of the flower-garden to remain: of thefe kinds are French Honeyfuckles, Seedling Pinks, Sweet Williams, Stockgilliflowers, Columbines, Dames-gillifiowers, Canterbury Bells, Hollyhocks, Scabioufes, Wall-flowers, Carnations, Fox-gloves, Campanulas, $\Xi c$. all of which mult be raifed in the flower-nurfery the firft feafon, and in the autumn tranfplanted into the flower-garden, to flower the following fummer.

You may now inoculate fome of the more curious forts of Rofes, which do not fend forth fuckers fo as to be increafed thereby: the beft ftocks for budding them upon are, the Francfort and Damank Rofes, which are the freeft thooters. You fhould now inoculate Jafmines, of all the kinds you want to increafe; and you may yet alfo inarch Jafmines of all thofe kinds which are rare : you may yet alfo inarch Oranges, Lemons, Citrons, Pomegranates, छ̋c.

Plant cuttings of Phlox's of the feveral forts, Double Sweet Williams, Double Scarlet Lychnifes, Pinks, late fowering Afters, and fuch fibrous-rooted plants as you want to increafe; which, if planted in a bed of light rich earth, Maded 


\section{June. The Gardeners Kalendar. 195}

maded from the fun, and duly watered, will take root very well.

\section{Plants nowe in Flower.}

Larkfpur, White Lily, Orange Lily, Red Day Lily, Everlafting Pea, Canada Goldenrod, Broad-leaved upright Dogibane, Apocynum Lillii convalii flore, Yellow and Biue Aconite, Horned Poppies of feveral fors, Capnoides, White, Back, and Yeilow Swallowwort, Veronicas, Blattarias, Scarlet Lychnis, Rofe Campion, Pinks, Double and fingle Virgins Bower, Flammula Jovis, Hyffop, Clarys, Oriental Buglofs, Double Ptarmica, Sweet Sultan, Xeranthemums, Herbaceous Coronilla, Jaceas, Santolinas, Acanthus of three forts, Snapdragons, Linarias, Tree Primrofe, Willow-weed or French Willow, Yellow Loofeftrife, White Loofeftrife, Valerianella Cornucopoides, two forts of African Marigolds, Hieraciums, Chryfanthemums, Lychnifes of feveral forts, Nigelia of two or three forts, Peach-leaved Bell-flower, Phlox's of three forts, Gentianella, White Wall-flower with double and fingle flowers, White and Red French Honeyfuckles, Lobel's Catchfly, Venus Navelwort, Flos Adonio, Venus Looking-glafs, Double and Single Sweet Wil- 
I96 The Gardeners Kalendar. June. liams, Double Catchfly, Bulbous fiery Lily, Martagons of feveral forts, Ornithogalums, Irifes, Bloody Cranefbill, Red, White and Garden Valerian; Greek Valerian with blue and white flowers, Oriental Ox-eye with yellow and white flowers, Bachelors Button with double and fingle flowers, Double Ragged Robin, Savoy and Tradefcant's Spiderworts, Poppies of various kinds, Columbines of various colours, Spanifh and Portugal Figwort, Indian Scabious, fome forts of Thrift, Candy Tuft, Dwarf Lychnis, Dwarf Annual Stock, Fox-gloves, Cornflags of two or three forts, White Hellebore, Yellow Perennial and Tangier Fumitories, Sea Ragwort, Africans, Female Balfamine, Periwinckles, Fraxinella with purple and white flowers, Great Blue and White Wolffbane, Chalcedonian Iris, Helianthemums, Sea Lavenders, Smilax, Afphodels, Eupatoriums, Cyanus's of feveral forts, Birthwort with long and round roots, St. Peter's-wort, Bean-caper, Double Camomile, Capficum, Greater Centaury, Dittany of Crete, Dragon, Fennel-Giant, Lavatera, Lavender, Sunflower of feveral kinds, Poley-mountain, Lupines, Water Lily, Cutleaved Lavender, Moth-mullein, Eaftern Caffida with yellow flowers, Alpine Caffida with large blue flowers, Chrifophoriana Virginiana, Great Yellow Gentian, Ruyfchiana of two 


\section{June. The Gardeners Kalendar. $\quad$ I97}

forts, Sweet Refeda, Phlomifes, Betony of feveral forts, Globe Thifle, Cirfiums, Trachelium, Pyramidal Campanula, Cerinthe or Honeywort, Purple Ragwort, Squill, Oriental Mallow, Perennial Yellow Adonis, Sea Holly, Alcea, Ketmia Veficaria of three forts, Sea Daffodil, Vulneraria flore Coccineo, with fome others of lefs note.

\section{Hardy Trees and Sbrubs now in Flower.}

Bladder Sena of two or three forts, Pomegranate with double and fingke flowers, Spanifh Broom, Broad-leaved Yellow Jafmine, White Jafmine, Rofes of various forts, Tamarin, Virginian Sumach, Dorycnium, Shrubby Althæa with a Briony leaf, Shrubby Althra with a fmaller flower, Oleafter, Ptelea, Nettle tree, Upright Sweet Canada Raspberry, Lime tree, Shrub Cinquefoil, Tree Germander, Late Red, Dutch, Evergreen, and Long-blowing Honeyfuckles, Spiræa with a Willow leaf, Spiræa with a St. John's-wort leaf, Shrubby St. John'swort, Canary Hypericum, Caterby's Climber or Carolina Kidney Bean tree, Perennial Shrubby Lamium or Bafe Horehound, Syringa, Medicago frutefcens, Mallow tree, three or four forts of American Hawthorns, two or three forts of Viburnums, Eafern Colutea, Pafion-flow- 
198 The Gardeners Kalendar. June. er, three or four forts of Virgins Bower, Spindle tree, American Dog wood, Diofpyros or Perfimon, Fringe or Snowdrop tree, Toxicodendron, Ciftufes of feveral forts, Phlomifes, Virginia Asacia, Catalpa, Amorpha or Baftard Indico, Caperbuh, Coccygria, Tulip tree, Clethra, Itea, Red and White Spiræa, Celaftrus, two forts of Melianthus, Small Magnolia, Cytifus Glaber nigricans, Hairy Cytifus, Diervilla, Scorpion Serna, Portugai Laurel, Double Sweetbriar, Periploca, Genifa of two or three forts, Wormwood tree, Colutea Ethiopica, Piftachia nut, American Dogwood, Tartarian Dogwood, Scarlet-flowering Horfe Cheftnut, and fome others of lefs note:

Medicinal Plants wobich may now be gathered for UJe.

Mullein, Speedwell, Figwort, Water Betony, Ros Solis or Sun-dew, Sanicle, Self-heal, Penny-royal, Red Poppy flowers, Pellitory, Catmint, Water Lily, Spear-mint, Pepper-mint, Yarrow or Milfoil, Scabions, Devil's bit, Feverfew, Melilot, Burner, Mallow, Black and White Horehound, Burnet Saxifrage, Sage of Virtue, Red Sage, Dittander or Pepperwort, Mountain Flax, Yellow Loofeftrife, Tanfey, Privet flowers, Stone-crop, Hare's-foot Tre- 
June. The Gardeners Kalendar. 199 foil, St. John's-wort, Hyfiop, Rupture-wort, Alifanders, An leaves, Herb Robert, Mufk Cranes-bill, Doves-foot Cranes-bill, Broom, Hedge Muftard, Hemp Agrimony, Strawberry fruit, Broad and Narrow-leaved Plantain, Dragons, Tarragon, Lavender Cotton, Ladies Bedftraw, Common Wormwood, Roman Wormwood, Lavender-fpike, Lime tree flowers, Bears-breech, Comfrey, Spinach, Maudlin, Mother of Thyme, Houfleek, Agrimony, Hemlock, Water Hemlock, Vervain-mallow, Thyme, Marfh-mallow, Succory, Ladies-Mantle, Pimpernel, Dwarf Elder, Reftharrow, Blue-bottles, Rofemary, Marigolds, Silverweed or Wild Tanfey, Germander, Orpine, Cyclamen root, Fox-glove, Mugwort, Borage, Buglofs, Sowthiftle, Garden Orach, Stinking Orach, Shepherd's-purfe, Honey-fuckle, Betony, Carduus Benedictus, Calamint, Avens, Knotgrafs, Camomile, Hounds-tongue, Eyebright, Rafpberry fruit, Damank Rofe, White Rofe, Red Rofe flowers, Elder flowers, Stexchas or French Lavender, and Brooklime.

Work to be done in the Grean-House, GARDEN and STOVE.

Your Orange trees, being now in flower, mould be conftantly fupplied with water in O \& 
200 The Gardeners Kalendar. June. dry weather, to encourage them to fet their fruit; and the earth on the furface of their tubs and pots hould be firred, and fome rotten neats dung laid thereon, raifing it round the outfide of the tubs or pots, fo as to make an hollow to contain the water; but you fhould never Jay any new dung upon the pots, nor put any heep or deer dung into the water to enrich it, as is by too many perfons practifed, to the great prejudice of their trees; for thefe ftrongly impregnated waters, inftead of affording nourihment to the trees, caufe their leaves to change to a pale yellow colour, and the trees are apt to flower out of the proper feafon, which renders them weak, and many times deftroys them in two or three years time. The beft water for thefe trees is fuch as is taken from rivers, or ponds, where it is fully expofed to the fun and air; fo that if you have no other than fpring or well water, it hould always be expofed to the fun and air two or three days before it is ufed. You muft alfo gather off the flowers as they blow, leaving but few upon each tree for fruit; and thofe only upon the ftrongeft branches, and where they are beft fituated to ftand.

Plant cuttings of Myrtles in a bed of light rich earth, obferving to water and Made them 
June. The Gardeners Kalendar. 20I until they have taken root; and now you may plant cuttings of Geraniums, Cytifufes, Leonurufes, Dorias, Elichryfums, Hermannias, African Sages, Othonna, African Marigolds, Lantanas, Halleria, African Starwort, Ciftufes, Fabagos, Lotures, Aretotis, Conyzas, African Sumachs, and many other exotick plants, which are fhrubby; but in choofing of the cuttings, take fuch as have no flowers on them, and thofe which have ftrength, and not fuch as have been drawn weak by ftanding too long in the green-houfe; treating them in the manner directed under their feveral heads in the Gardeners Dictionary.

You may now hhift any of your greenhoufe plants, putting fuch as require it into larger pots, obferving to pare off all the mouldy and decayed roots, which generally grow round next the fides of the pots; and take out as much of the old earth from the ball as you can conveniently, without leaving their roots too bare. When they are new planted, they mould be placed in a thady fituation, where they may be defended from ftrong winds; it will alfo be proper to fupport them by driving ftakes into the ground at proper diftances, to which a rail fhould be faftened at a convenient height from the ground, and the ftems of the plants 


\section{The Gardeners Kalendar. June.}

plants faftened to the rail, to prevent the wind from difplacing the plants until they have taken new root, after which they may be removed to the places where they are to remain during the fummer feafon: but it will be proper to faften their ftems when removed to a rail, to prevent their being blown down by the wind.

'Take off cuttings from the feveral kinds of Cereufes, Sedums, Eupborbia's, Mefembryanthemi's, Cotyledons, Indian Fig, Craffulas, Klenias, and other fucculent plants as are wanted for an increafe, laying them in a thady part of the ftove for about a fortnight, that their wounded parts may heal over before they are planted, otherwife they will be in danger of rotting.

Stir up the bark in thofe hot-beds which have been long made, and, where it is wanted, add fome new bark to them, which will renew their heat, and plunge the pots down again immediately; this thould be done in foft warm weather, when there is little wind, left, by expoling the plants in cold weather to the open air, they Phould fuffer; or if the weather is bad, the plants fhould be carried into the ftove while this is doing, for tender plants will not bear the open air, when the wind is frong or cold. 


\section{June. The Gardeners Kalendar. 203}

In hot weather you hould give air freely to your moft tender exotick plants : and in fmalt ftoves, where the plants are near the glaffes, it will be of great fervice to the plants, to Arade the glaffes with mats in the great heat of the day; but in large ftoves, where the plants have room, they will not require to be fhaded, unlefs at fuch times when they are new-potted, till they have taken frem root.

Tranfplant fuch feedling cxotick plants as were raifed in the fpring, into feparate pots; and fuch of them as are very tender, fhould be plunged into a frefh hot-bed, to promote their growth; but thofe which are hardy, will only require to be Theltered until they have taken root, after which time, they may be removed to the places where they are to remain the fummer feafon.

You may now take up the roots of the $\mathrm{Ca}$ nary Campanula, and moft of the bulbous and tuberous-rooted plants which come from the Cape of Good Hope ; as the Hæmanthus, African Cornflag, Blue tuberous rooted Crinum, Sifyrinchiums, Squills, Perfian Cyclamen, $\mathrm{Cu}-$ nonia, Watfonia, Antholyza, Ixia, Ornithogalums, and feveral other forts whofe leaves are decayed: at this time their roots may be fafely

$\operatorname{tranf}-$ 


\section{The Gardeners Kalendar. June.}

tranfplanted, or may be carried to a diftant place, if they are carefully wrapped up in mofs; but there are fome which will require to be planted into pots of frefh earth immediately, placing them where they may have the morning fun till eleven o'clock, and give them nowand-then a little water in very dry weather; but do it Sparingly, until they puh forth new leaves: for much water at this. feafon, when the ronts are almoft inactive, will rot them.

This is alfo a proper feafon for tranfplanting the roots of the Guernfey and Belladonna Lilies, their leaves being entirely decayed ; and at this time freh roots thould be procured from abroad; for thofe which are taken up afterwards, when they have put out new routs, feldom fucceed fo well. The roots of the former thould be planted in pots filled with the following compoft, or in a warm border where they can be fcreened with mats in hard frofts to preferve their leaves; viz. one third part freth earth from a pafture, a third part of fea fand, and a third part of lime rubbih. Thefe fhould be well mixed, and the bottoms of the pots or the borders covered with ftones, to make an open paffage for the water to drain off; then fill the pots with the comport, and place the roots therein, and fet the pots in a fituation where 
June. The Gardeners Kalendar. 205 they may enjoy the morning fun, but give them. but little water until they begin to puin out their leaves, and afterwards they fhould havo it fparingly. The fecond fort which is pretty hardy, will thrive beft if the roots are planted in warm borders; but if the ground is moift, the borders thould be raifed fo high, as that the wet may not come near the bulbs, and fome rubbin thould be laid at the bottom to drain of the moifture.

The Tuberofes, which were planted early, will now begin to flower, when thofe which were planted upon the hot-bed may be removed into pots (preferving as much earth as poffible to their roots) and placed where they are defigned to remain for flowering, obferving to refrefh them often with water; and thofe which were planted later, in order to fucceed thofe firt planted, muft have as much free air as poffible, and be frequently watered; which will render them ftrong, and caufe them to produce a greater quantity of flowers.

The Anana plants muft now be frequently refrefhed with water, but this thould not be given them in too great plenty; and in hot weather they fhould have much free air, efpecially thofe under frames or in very low ftoves; for if the glaffes are kept too clofe down, their 


\section{The Gardeners Kalendar. June.}

leaves will be fcorched, to the great prejudice of the plants, and the fruit will be lefs delicate; but if they have too much water, and the glaffes apened too much in the day-time (as fome have injudiciounly done), the plants will fuffer as much that way; for, upon proportioning the quantity of air, and water equally, depends the whole fuccers.

In the middle of this month you may begin to take out of the ftove fome of the hardier forts of Aloes, and other fucculent plants, placing them at firft in the green-houre, where they may have a large thare of air to harden them for a few days; then they may be placed abroad in a fhady fituation, where fnails and other vermin are not in too great plenty; for when they are expofed to the violence of the fun as foon as they are taken out of the houfe, they change colour, and appear unfightly, fo they thould be inured to it by degrees: but if fnails or flugs can come to them, they will gnaw their leaves, and greatly deface them. After the ftove is thinned of fome of thefe hardier forts, the other more tender plants fhould be placed at a greater diftance on the ftands, and cleaned from filth, by which they will enjoy more air, and be rendered ftronger, and more vigorous; and fuch of them as will bear the open air in the middle 
June. The Gardeners Kalendar. 207 of fummer, will be better prepared to be placed abroad the beginning of the next month.

Plants in Fiorver in the GREEN-HOUSEz GARDEN and STOVE.

Oranges, Lemons, Limes, Citrons, and Shaddocks, Myrtles, Olives, Ciftus Halimi folio, Male Ciftus of feveral forts, Ciffus Ledon, Pforalea, African Willow-leaved Afclepias of three furts, Arctotus of feseral forts, large yellow and African white Gnaphaliums, Nlexleaved Lantana, Hibifcus with a divided leaf, and another with efculent fruit, Cotton plant, Mefembiyanthemi of feveral kinds, Indian Yellow Jafmine, Sedums of feveral forts, Ethiopian Colutea, Shrubby African Mallow, Barba Jovis or Silver-bufh, Dwarf American Campanula, African Tree Scabious, Baffella, Melianthus two furts, Mimofa of three or four forts, White Spanifh Broom, Cotyledons, Iatropha with a multifid leaf, and another with a leaf like Stavesacre, Maranta or Indian Arrow root, Double Indian Nafturtium, Coffee tree, Shrubby African Polygala, Amomum Plinii, African Sages of two or three forts, Azorian Jafmine, Aloes of feveral forts, Dwarf Pomegranate, Indian flowering Reed, Fhlonifes three or four forts, Canary Broom, 


\section{The Gardeners Kalendar. June:}

Geraniums of feveral forts, feveral forts of $\mathrm{Paf}-$ fron flower, Plumeria, Caffia, Oleanders, Teucricum Bæticum, Cretan Lotus, Lotus Hæmorrhoidalis major and minor, Coral tree, Beancaper, Hermannias, Lentifcus, Euphorbias, African Pancratium, Abutilons, Papaws, Cereufes, Lantanas, Crotolarias, Anonifes, Double Thorn Apple with purple and white flowers, Lotus with black flowers, Diofma of three forts, Heliotropiums, Lyciums, Celaftrus, Martynia of three kinds, Canary Lavender, Crinum, Piper two forts, Tabernemontana, Waltheria, Tournefortia, Brunsfelfia, Vinca from the ifland of Bourbon, Solanums, Alkekengi of feveral forts, Arums, Hæmanthus Cholchici foliis, Anthericums, Piercea, Melon Thifte, Gefneria, Shrubby Canary Foxglove, Adhatocia of two forts, Kiggelaria, Grewia, American Afclepias, Clutia, Pafferina, Phyllanthus, Tithymalus, Phytolacca of three forts, Chironia, Afcyron Balearicum, Arabian Jafmine, Shrubby Convolvulus, African Shrubby Lavatera, Rauvolfia, Bafteria, Wormwood tree, African Sumachs, Borbonia, Laurus Regia, Sørrel tree, Eraffula, Palm tree, Malpighias, Turnera, Hedyfarums, Bupleurum arborefcens, with fome others. 


\section{[209]}

a s)

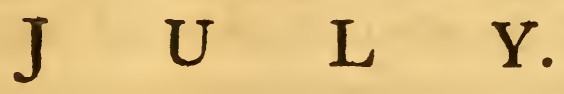

\section{Work to be done in the K I T C II E N- G A R D E N.}

and beginning of this month fow

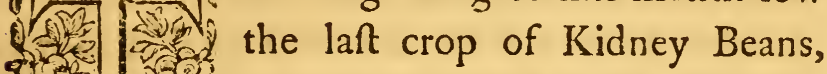
Niv 3 in a fituation where they may be (5) (1) (1) autumn; for this crop will continue bearing till Michaelmas, provided they are not injured by froft. If the ground is very dry when thefe are planted, it will be proper to foak the Beans fix or eight hours in water before they are planted, which will greatly facilitate their growth: the beft fort for this planting is the Scarlet-flowering Kidney Bean, which will continue bearing until the froft deftroys the plants.

Cleanfe the ground where the firft crop of Cauliflowers grew, from the leaves of the Cauliflowers which have fcattered, and any other 
210 The Gardeners Kalendar. July. rubbilh or weeds which may be there; and if you have Cucumbers for picklers, between the wide rows (as is the common practice of the London gardeners), you muft draw up the earth round the holes, in which the plants grow with a hoe, forming it in a hallow like a bafon, to contain the water given them; and if there are Cabbages for winter ufe, in the narrow rows (which is alfo by the fame gardeners practifed), they thould have earth drawn to their Atems, and the whole ground entirely cleared from weeds.

About the end of this month you fhould fow Spinach for winter ufe, as alfo Coleworts, Carrots, and Onions, to ftand the winter for fpring ufe; and Turneps for the laft crop, mould now be fown in the open field for to come in the fpring. Tranfplant Savoys, Broccoli, and Cabbages, for fpring ufe, and plant out Cauliffowers for the autumn crop.

Plant Celery into drills for blanching (if it be of the Italian fort ; but if it be the Turneprooted fort, it is better to plant it on level ground) drawing up a fmall ridge of earth on each fide to prevent the water from efcaping; and plant out Endive for blanching. Continue fowing all forts of fmall fallet herbs, which, at this feafen, foon grow too large for ufe. 
July. The Gardeners Kalendar. 2 I I In dry weather, obferve to water all fuch plants as have been lately tranfplanted, and be fure always to do this in an evening; for one watering at that time is of more fervice than three at any other time of the day, the moifture having time to penetrate the ground (and reach to the extreme fibres of the root, by which they receive their nourifhment), before the fun appears to exhale it; whereas when is is given in the morning, the fun coming on foon after, the moifure is drawn up before it reaches the root; and where there is convenience to lay mulch upon the furface of the ground about the roots of plants, that will prevent the fun from exhaling the moifture, fo that one watering will be of more fervice than three or four, where that is wanting.

You muft now diligently deftroy the weeds in every part of the garden, which if fuffered to remain, will foon perfeet their feeds; and when thefe are permitted to fcatter upon the ground, they will fill it with weeds for feveral years crop, to the no fmall trouble of the gardener, as alfo to the great injury of the crops. Obferve alfo to clear dunghills from weeds, for thefe are too often neglected; and if the weeds are permitted to feed there, they will be brought into the garden, and be as troublefome 


\section{The Gardeners Kalendar. July.}

as if they had fcattered in it, which is what few people regard, though it is a thing of great moment; as is alfo the keeping the borders round the outfide of the garden free from weeds, efpecially thofe weeds which have downy feeds; for thefe will be wafted by the winds into the garden, and produce a plentiful crop.

Gather feeds of Spinach, Corn fallet, Wellh Onion, Crefs, and all other forts that are ripe, cutting off their ftalks, and fpreading them upon mats or cloths in a dry airy place, that they may harden; and then rub or beat them out of their hufks or pods, and put them up in a place where vermin cannot come to them to deftroy them.

Pull up Onions, Garlick, Rocamboles, Efchalots, $\mathcal{E}^{2} c$. when their leaves begin to wither; and fpread them thin in a dry airy place, that they may be perfectly dry before they are laid up for winter ufe.

Continue to earth up your firft crop of Celery, which was planted in the drills the former months, as it advances in height ; but be careful not to draw the earth up into the heart or middle of the plants, for that will ftop their growth, and rot them. Tie up the Endive

which is full grown, to blanch it, obferving 
July. The Gardeners Kalendar. 2 I 3 always to do this work in dry weather; for if the leaves are moift when they are tied, théry will rot in the middle.

Pull up the ftalks of Beans, Cabbages, $\mathcal{E}^{3}$. and the haulm of Peas, and other leguminous plants which have done bearing, that the ground may be clear ; for if thefe are permitted to remain, they will harbour vermin, to the prejudice of your adjoining crops.

Your Melons, which now begin to ripen, Chould have no water given them, becaufe that will render them watery and ill-tafted; though perfons who are fond of very large fruit, find their account in fupplying their plants conftantly with water in great plenty, efpecially in hot weather; but thefe perfons do not regard the quality of their fruit, fo much as the fize of them; for which reafon, the market gardeners always prefer the hardy forts of Melons, which produce the largeft fruit, though they are not better flavoured than Pumkins.

In this month you may repair your young Afparagus beds which were planted the laft fpring, by planting freth plants where any of them have failed; but this thould be done in moift weather. The young plants which are planted at this feafon will be well rooted before

$$
\text { P } 3 \text { winter, }
$$


214 The Gardeners Kalendar. July. winter, and put out fome hoots in the autumn.

The Cucumbers which were brought up under hand-glaffes, being now in full bearing, muft be duly watered in dry weather, otherwife they will be exhaufted in a fhort time, and decay.

Tranfplant the Celery into beds which was fown in May, that the plants may acquire ftrength before they are planted into drills: and tranfplant fome Endive, to fucceed that which was planted the former month.

Now you may fow the Turnep-rooted Radifh, which will be in great perfection for the table in October, and continue good until the hard froft deftroys them: and where the common fort of Radin is required for the table in autumn, if fome feeds are fown on moift ground the latter end of this month, they will be fit to draw in a month or five weeks after, and will continue good a month longer.

Clear the Artichokes, which were planted the laft fpring, from weeds, and all other crops which were fown between them, that they may have full liberty to fpread; for if they are crouded with any other plants at this feafon, they will produce fmall fruit; and thofe Artichokes which are now fit for ufe upon the old 
July. The Gardeners Kalendar. 215 old ftocks, hlould have their ftems broken down clofe to the furface of the ground, that the roots may not be injured by leaving the bottom of the ftems upon them, as is too often practifed by unfkilful gardeners.

You may now fow fome Broccoli feed for the laft crop, which will be fit for ufe in April, after the heads of all the former crops are gone, when there are only the fide fhoots of them remaining; and thefe late fown plants will produce much more tender heads than any of the former fowings, though not fo large.

Sow fome Endive for the laft crop, about the middle of this month, to fucceed that which was fown the former month, which will not continue fit for ufe much longer than October; whereas the plants of this fowing will continue until April, if they are not deftroyed by fevere froft.

Where fmall fallet herbs are required, they nhould now be fown on north borders, and thefe fowings repeated every three or four days; for at this feafon they will foon grow too large for ufe.

The Cos, Cilicia, and other forts of Lettuce, which were fown the laft month, muft now be tranfplanted out thefe, if the au-

$$
\text { P. } 4
$$

tumn 


\section{The Gardeners Kalendar. July.}

tumn proves favourable, will be fit for ufe in September.

\section{Products of the KITCHEN-GARDEN.}

Cauliflowers, Artichokes, Cabbages, Carrots, Beans, Peas, Kidney Beans, Turneps, Lettuce, Cucumbers, Melons, and all the forts of fmall fallet, as Radirh, Rape, Muftard, Creffes, Purflane; and from the ealy fowing, Celery and Endive; Finochia, Onions, Garlick, Rocambole, Parney, Sorrel, Chervil, Scorzonera, and Salfafy of the firft fowing, Beets, Horfe-radih, fome early planted Potatoes; on moif ground Radihes and Spinach, Marigolds, Tomatos for foups, where they have been raifed early, and are growing in warm fituations, Burnet, Borage, Buglors, Mint, Baum, Sage, Thyme, Sweet-majoram, Bafil, with fome other aro* matick plants and herbs for foups.

Work to be done in the FRUIT-GARDEN and VINEYAR D.

The beginning of this month you muft look carefully over your wall and efpalier trees, rubbing off all foreright hoots that are produced; and train all fuch regular hoots as 


\section{July. The Gardeners Kalendar.}

are defigned to remain clofe to the wall or efpalier, in their due pofition; whereby the fruit will have the advantage of fun and air to ripen them, and give them their proper flavour. If this be rightly executed, there will be no occalion to diveft the branches of their leaves, as is by fome unfkilful perfons practifed, to the great prejudice both of their fruit and trees: nor can I here forbear repeating, what I have elfewhere often taken 1 otice of, viz. not to fuffer fruit trees to remain neglected till this feafon (as is too often practifed) and then to fummer-prune them (as it is commonly called), in the doing of which, the gardeners cut off all the luxuriant branches, and horten thofe defigned to remain, and then nail them clofe to the wall, fo that from being (before this dreffing) in a very rude diforderly way, they are reduced into an exact order at once; but hereby the fruit, which was greatly Thaded by the luxuriant growth of the branches, is fuddenly expofed to the fun and air, whicl hardens their outward fkins, and retards their growth; whereas, if their moots had been conftantly trained to the wall or efpalier, as they were produced, the fruit would have continually been under an equal coverture of leaves, and fo confequently lefis liable to fuffer from 


\section{The Gardeners Kalendar. July.}

any extremes of weather; whereby they would alfo be confiderably forwarded in their growth, than when they are managed in the other way; fo that as this practice is too generally followed, I think it cannot be too much expofed, and the proper directions cannot be too often inculcated.

In the beginning of this month you muft bud all forts of fruits, which were not done the preceding month, obferving always to do it in an evening, or in cloudy weather.

Hoe and clean your ground about your efpalier trees from weeds, as alfo the borders near wall-fruit-trees; for if they are permitted to grow at this feafon, they will rob the trees of their nourifhment; and cut off all fuckers which arife from the roots of the trees, as they are produced; for thefe injure them much, if they are fuffered to remain.

Look carefully after fnails in the mornings and evenings, but efpecially after a hower of rain, when they will be tempted to come abroad, and may be at that time eafily taken; for thefe vermin do great mifchief, but particularly to ftone fruit.

Place glafs phials filled with honey-water in different parts of the walls, to deftroy wafps and pirmires, which would infert the choice fruit ; 


\section{July. The Gardeners Kalendar. 219}

fruit; but are by the fweetnefs of the water tempted into the phials, and frequently drowned; but thefe Thould be hung before the fruit begins to ripen, for then they will be much fooner tempted to the water, than after they have tafted the fruit: where there are a fufficient number of thofe glaffes placed againft the walls in time, the fruit may be preferved from thefe vermin.

The Vineyard muft now be carefully looked over, and all dangling thoots and wild wood muft be difplaced, that the fruit may not be too much covered with leaves; but by no means diveft any of the fruit branches of their leaves (as fome unfkilful perfons too often practife), for thefe are abfolutely neceffary to the growth of the fruit; nor will there be any occafion for this praciice, where the moots are duly placed, and the luxuriant fhoots conftantly rubbed off as they are produced. Where this method is begun early in the feafon, and conftantly purfued, as there may be occafion, the fruit will be forwarded above three weeks (as I have experienced), and will be much fairer, and better tafted, than in the contrary management ; for when the fhoots of the Vines are permitted to hang loofe from the wails of ftakes, their leaves will take a contrary di- 


\section{The Gardeners Kalendar. July.}

rection, which, upon having their hoots afterwards faftened up in their right pofition will have their back-fide upward: and until thefe leaves are turned into their proper pofition, the fruit will be at a ftand, and make no progrefs in their growth, which is commonly eight or ten days in effecting; fo that the fruit lofes eight or ten days in the principal feafon of its growth, which, together with being too much chaded in the former months, is fcarcely ever to be retrieved in this climate.

You muft alfo keep the ground conftantly cleared from weeds and other plants between the rows of Vines, which is alfo of great confequence in this country; for where there are other plants fuffered to grow, they not only rob the rcots of the Vines of their nourihment, but alfo, by perfpiring, caufe a damp in the air about the Vines, and prevent the fun and wind from drying the furface of the ground; whereby the fruit is filled with crude nourifhment, and rendered lefs delicate.

Look carefully over your fruit trees, which have been budded or grafted the former feafon, and obferve that no thoots from the ftocks remain, for thefe will rob the buds or grafts of their nourihment.

Where 


\section{July. The Gardeners Kalendar. 221}

Where any of your fruit trees againft the walls or efpaliers, are not of the forts which you defire, they thould now have buds of thofe kinds put ints their tender fhoots; if there are feveral buds put into different parts of each tree, when they fucceed, the walls or efpaliers will be foon covered by them again, with the defired kinds, fo that by this method the trees will be in full bearing in three years; whereas when the trees are deftroyed, and new trees planted in their places, they will be feven or eight years before they arrive to that perfection.

\section{Fruits in Prime, or yet lafing.}

Pears; the Primitive, Robine, Petit Mufcat, Mufcadelle-rouges, Cuiffe-Madame, Petit Blanquette, Jargonelle, Green Chiffel, Orange Mufque, with fome others; and where they have been well preferved, the Black Pear of Worcefter, and Lord Cheyne's Green Pear, are yet in being.

Apples; Codling, Margaret Apple, White Juneating, Stubbard's Apple, Summer Corting, Summer Pearmain, Pomme de Rambour; and ftill continue the Deaux Ans or John Apple, the Stone Pepin, and Oaken Pin, of the former year.

Cherries; 
222 The Gardeners Kalendar. July.

Cherries; Kentih, Duke, Gafcoign's Heart, Carnation, Lukeward, Ox-heart, Amber-heart, Coroon, Amber, White Spanin, and Black Cherries.

Peaches; Brown and White Nutmeg, and Anne Peach.

Nectarine; Fairchild's early Nutmeg.

Plums; Jaun Hative, Morocco, Orleans, Blue Primordian, Violet Royal.

Apricots; the Orange, Roman, Breda, Algier, and Turky.

As alfo Goofeberries, Rafpberries, Currants; and, in cold fituations, the White, Green, and Chili Strawberries; and, in the ftove, the Ananas or Pine Apple.

\section{Work to be done in the NURSERY.}

Continue to bud Apricots, Peaches, Nectarines, Cherries, Plums, Pears, $\mathcal{E}^{2} c$. This mould, if poffible, be performed in a cloudy day, or in a morning or evening, when the fun is not viclent, becaufe the cuttings are very apt to Mrink in very hot fun-Thine, which caufes the bud to adbere too clofely to the wood, unlefs they are put in water, which is what many people practife; but this is not fo proper; for thofe buds, which are covered with water, will 
July. The Gardeners Kalendar. 223 be fo much faturated with moifture, as to pre- vent their uniting with the ftock, fo that they often mifcarry: therefore, when it is neceffary to put them into water, there hould be only the lower part of the cuttings immerfed about an inch; for the upper part will attract the water better, than if the cuttings are entirely covered.

In about three weeks after the ftocks ate budded, you hould look over them to loofen the bandage, otherwife the buds will be pinched, and greatly injured, if not deftroyed.

Obferve to keep your nurfery clean from weeds at this feafon, for now the weeds will foon ripen their feeds, if they are permitted to remain, which will fill the ground fo as not to be cleared again for years.

You muft continue to train your evergreen tress for the purpofes they are defigned: and where any of your foreft trees hoot too vigorounly near their roots, thofe branches may be pruned off, to encourage their heads.

Keep your beds wherein your young ftocks and trees were fown in the fpring, clear from weeds; and in very dry weather fupply them with water, which will greatly promote their growth. 
224 The Gardeners Kalendar. July. About the middle of this month, if the feafon proves moirt, you may fafely tranfplant many forts of evergreen trees; as you may alfo tranfplant young feedling Pines and Firs from the pots or cafes in which they were fown; but the beds where they are planted, fhould be Thaded with mats every day until they have taken root; where this is obferved, the plants will foon be rooted, and make a great progrefs, fo that it is by much the fureft feafon for this work : but this is chiefly to be underftood of young feedling plants, and where they are not to be removed to any great diftance; for their roots are foon dried, when they are taken out of the ground at this feafon; therefore they mould be planted again inmediately, otherwife the fibres of their roots will dry, whereby they will fuffer greatly: therefore, when thefe plants are carried to any little diftant place, their roots thould be placed in fhallow pans of water, or covered with wet mofs during the time they are out of the ground.

Work to be done in the PLEASURE-GARDEN and WILDERNESS.

Take up the bulbs of fuch late flowers as were not fit the laft month; fuch as Ornithogalums, 
July. The Gardeners Kalendar. 225 galums, Red Lilies, Martagons, and fome other forts; and tranfplant the roots of Perfian and Bulbous Irifes; as alfo Fritillaries, Hyacinth of Peru, Dens Canis, Narciffufes, and fuch other bulbous and tuberofe-rooted flowers which will not endure to be kept long above ground; and this being the feafon when they are not in action, is the moft proper time for tranfplanting them, before they put forth new fibres, after which time it will not be proper to remove them.

Continue to make layers of Pinks, Carnations, Sweet Williams, $\mho c$. where it was not done the former month; but the fooner this is done the better, provided the thoots are ftrong enough to lay down.

Tranfplant fuch biennial or perennial fibrous-rooted flowers as were fown late in the fpring; fuch as Pinks, Carnations, Stock-gilliflowers, Wall-flowers, Hollyhocks, French Honeyfuckles, Canterbury Bells, Scabioufes, Pyramidal Bell-flower, Scarlet Lychnis, Rofe Campion, Fox-gloves, Tree Primrofe, Greek Valerian, Columbines, Polyanthufes, and fome others, which fhould be planted in nurferybeds, where they may have room to grow until Michaelmas, when they thould be tranfplanted into the borders of the tlower-garden.

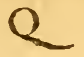

C'ean 


\section{The Gardeners Kalendar. July.}

Clean your borders diligently from weeds, but efpecially fuch forts as foon thed their feeds; for if they are permitted to ftand until their feeds are fcattered, it will be a conftant trouble for feveral years to extirpate them.

Gather the feeds of all forts of flowers as they ripen, drying them in the thade, and preferve them in their hufks or pods until the feafon for fowing them; but you thould let them be well dried before they are put up, otherwire they will grow mouldy and decay.

Cut down the ftalks of fuch flowers as begin to wither and decay, and tie up all tall-growing plants which are yet to flower, left the winds blow them down and break them.

Inoculate Rofes, Jafmines, and other forts of curious flowering fhrubs and trees, this month being the principal feafon for this work.

Cut and trim hedges, clip box-edgings, mow grafs-plats, and keep the walks confantly rolled; and the weeds thould be carefully taken out of them, for if they are fuffered to remain at this feafon, they will feed in a little time, and fill the waliks with weeds.

Your choice Carnations being now in flower, Mould be carefully attended, to open the pods, when they begin to burft on the contrary fide, that they may blow equally; for if 
July. The Gardeners Kalendar. 227

this is not done in time, the flower leaves will come all out on one fide of the pod, and render them ill thaped. You muft alfo guard them from infects, efpecially ants and earwigs, which will deftroy them in a thort time if they can come to them; the fowers Should alfo be covered with glaffes, bafons, or oiled paper, to keep off the wet, and the fcorching heat of the fun. But in all this, there muft be great diligence in managing them according to the temperature of the feafon, where perfons would excel in the largenefs and beauty of their flowers; therefore, the large Carnations are not fo proper for perfons who have much other bufinefs on their hands, but rather for thofe who want fome fuch eafy employment to divert themfelves.

You may now increare the Double Scarlet Lychnis, by planting cuttings of the flowerftems, each of which thould have three or four joints; two or three of which Mould be put into the ground, and the other left above ground: thefe mult be put in a hady border of light freth earth, obferving to refrem them with water according to the drought of the feasan; and if thefe cuttings are clofely covered with handglaffes, they will more certainly take root.

Toward the latter end of this month you may take off the layers of Pinks, Carnations,

$$
\mathrm{Q}_{\operatorname{mat}} \mathrm{C}
$$

Sweet 
228 The Gardeners Kalendar. July. Sweet Williams, छ6. which have taken root; and plant them either into pots or borders of good freth earth, where they may continue until you have conveniency of planting them where they are to remain for flowering; for it is not proper to let them continue too long upon the old roots, becaufe if thofe fhould not be found, the layers would be infected by them; but when you plant thefe out, they mut be carefully watered and Thaded until they have taken root. When thefe layers are cut off from the old roots, that part of the ftaik which came from the old root, hould be cut off clofe to the place where it was nit when they were laid down, and their leaves Should be trimmed.

The latter end of this month you fhould fow fome feeds of annual flowers, in warm borders, to ftand through the winter, that they may flower early the next fummer; by which method you may obtain good feeds of many forts of plants, which if fown in the fpring, do not conftantly ripen their feeds in this climate; fuch as the Great Blue and Flefh-coloured Lupines, Sweet-fcented Peas, Sweet Sultan, Anaftatica, fome forts of Orobus, Double Larkfpur, Annual Stock, Venus Navelwort, Xeranthemums, Jaceas, with fome others. If thefe plants 
July. The Gardeners Kalendar. 229 plants live through the winter they will not only come earlier to flower, but will alfo grow much larger, and produce their flowers in much greater plenty ; and thofe which have double flowers, will be much fuller than thofe which are fown in the fpring; for which reafon when the winter proves fevere, it will be very proper to fcreen fome of the tendereft forts from froft.

Your choice Auriculas hould now be kept clear from weeds, and all decayed leaves, which, if fuffered to remain upon therh, would rot and fpoil them; they thould alfo be placed in a fhady fituation, but not under the droppings of trees.

The feedling Auriculas, which came up the laft fpring, muft now be planted out into tubs or pots filled with rich earth, and placed in a Thady fituation; and as they are fmall, fo they munt be treated tenderly, giving them water gently; and be careful, that they are not drawn out of the ground by worms, nor eaten by fnails or flugs, both which vermin are great enemies to them.

Keep the walks and quarters of your wildernefs free from weed and litter, and fuch trees as grow too much out of order may be pruned, fo as to render them beautiful; for this is a feafon, when wilderneffes and thady walks are chiefly frequented; fo that they

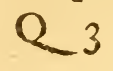

mould 
230 The Gardeners Kalendar. July. fhould be well kept, otherwife they will be difagreeable.

In the beginning of this month you may bring your moft tender annual plants out of the hot-beds; fuch as Amaranthufes, Gomphrena's, Datura with double flowers, Martynia, Mefermbryanthemi, Double Balfamine, and fome others; which hould now be placed in the parterre-garden, to fupply the borders where the fpring flowers did grow, and are now paft; fo that by this fucceffion, the borders may be kept in beauty through the fummer.

Plants now in Flower in the PLEASUREGARDEN.

Carnations, Pinks, Sweet Williams, Fairchild's Mule, Double and Single Ragged Robin, Dwarf Annual Stock, French Willow, Single and Double Virgins-bower, Antirrhinum or Calves-fnout, Linarias of feveral forts, Centauria of feveral forts, Everlafting Pea, Sweet-fcented Pea, Tangier Pea, Blue-flowered Lathyrus, Hieraciums, While Lily, Scarlet Martagon, Day Lily, Ornithogalum Spicatum, White Hellebore with green and purple flowers, Aconitum luteum, Anthora, Aconite with large blue and white flowers, Acanthus, La-

vateras, 
July. The Gardeners Kalendar. 23 I vateras, Indian Scabious, Sea Holly of four or five forts, Sweet Sultan, Poppies of divers kinds, Peach-leaved Campanula, Venus Looking-glafs, Venus Navelwort, Double Ptarmica, Double Feverfew, Double Chamomile, Buphthalmums of two or three kinds, Annual Stock-gilliflower, Double Rofe Campion, Larkfpurs, Spanin Scrophularia, Nigella, two forts of African Marigolds, Lupines of feveral forts, Amaranthufes, Gomphrenas Capficum Indicum, Xeranthemums, Red Garden Valerian, Holyhock, Carolina, and Spiked Phlox, Sunflowers of feveral forts, Virginian Spiderwort, Scarlet Lychnis, Golden-rods of feveral kinds, French Marigold, Female Balfamine, Marvel of Peru, China Pink, fome early forts of Starwort, Dwarf Lychnis, Candy-tuft, Mallows of feveral kinds, Nafturtium Indicum majus \& minus, Chryfanthemums, Ricinus or Palma Chrifti, Globe-thiftle three or four forts, Campanula Pyramidalis, Limoniums of $\mathrm{fe}-$ veral kinds, Catanance quorundam, Eupatoriums, Greater Centaury of feveral forts, Statice Major, Sida of feveral forts, Adonis three or four kinds, Glycine, Buphthalmums, Inula, Aftragalufes, Molucca Baum, Cardinal flowers, Red and White Chelone, Moth-Mullein, Po-

$$
\text { Q4 }
$$


232 The Gardeners Kalendar. July. ley-mountain and feveral other forts, Dittany of mount Syphilis, Tobacco of feveral forts, Tree Primrofe, Clove-gilliflowers, Double and fingle Sopewort, Coronilla herbacea, Heliotropium majus, Trachelium umbellatum, Eryngiums, Monarda two or three forts, Achillea of feveral forts, Dittany of Crete, Caffida of feveral forts, Lyfimachia Spicata, Double Marigold, Dracocephalum of feveral forts, Birds-foot Trefoil, feveral forts of Convolvulus, Apocynums of two or threekinds, Swallow-wort with black and yellow flowers, Alyffums, Sclarea of feveral forts, Spigelia or Indian Pirk, Mimulus, Dianthera, Parth nia, Dodartia, Conyzas, Cannacorus of North America, Amethyftea, Horminums, Purple and Yellow Honeywort, Sartolinas, Rudbeckia three or four forts, Silphiums, Ginfeng, Scarlet Beans, Tangier Fumitary, Veronicas, Ruyfchiana of two forts, Fabago Belgarum, Helianthemums of feveral forts, Pocock's Iris, Carolina Reft-harrow, with fome others.

Hardy Trees and Sbrubs nowe in Flower.

Several forts of Rofes, Spanifin Broom, White Jafmine, Dwarf Yellow Jafmine, Canary Hypericum, Shrubby Stinking Hypericum, 
July. The Gardeners Kalendar. 233 Double and Single Pomegranate, Virginian Trumpet-flower, Agnus Caftus, or the Chafte tree, Male Ciftus feveral kinds, Ciftus Ledon feveral forts, Phlomis or Sage tree of feveral forts, Oleafter, Shrub Cinquefoil, Spiræa with Willow leaves, Spiræa with Marfh Elder leaves, Althæa frutex, Paffion flower, Cytifus Lunatus, Glycine of two forts, Bladder Sena, Dutch Honeyfuckle, Evergreen Honeyfuckle, Longblowing Honeyfuckle, Late White Honeyfuckle, Scarlet Virginian Honeyfuckle, the Tulip tree, Virginian Sumach, Myrtle-leaved Sumach, Genifta Tinctoria, Geniftella, Cytilus hirfutus, Elm-leaved Sumach, Celaftrus, Red Spiræa, Itea, Clethra, Hydrangea, Periploca, Bignonia of two or three kinds, Anonis of feveral forts, Cytifus Glaber nigricans, Tartarian Cytifus, White Spanin Broom, Mallow tree, Wormwood tree, Three-thorned Acacia, Pavia, Baftard Indigo, Azederach, Luca Broom, Flowering Rafpberry, Catalpa, Diervilla, Mufk Rofe, Kalmia, Virginian Dogivood, Saffafras, Ceanothus, Dahoon Holy, Portugal Laurel, Magnolias, Hollies, Privet, Monthly Rofe, Wild American Rofe, Pihamin, Myrica or Cneorum Candeberry Myrtle. Tamarin, Clematis with blue flowers, Spartium Triphyllum, with fome others. 
234 The Gardeners Kalendar. July.

MEDICINAL PLANTS wbich may now be gatbered for UJe.

Tormentil, Winter Savory, Ros Solis or Sun-dew, Sneezewort, Penny-royal, Clowns Woundwort, Origany, Catmint, Milfoil or Nofe-bleed, Spear-mint, Pepper-mint, Feverfew, Melilot, Black and White Horehound, Toadflax, Sage of Virtue, Red Sage, Wormwood Sage, Wild or Wood Sage, Mountain Flax, White Lily, Water Lily, Rue, Dittander or Pepperwort, Lovage, Mafterwort, Mullein, Sciatica Crefs, Speedwell, Jafmine flowers, Hyffop, Clary, Oculus Chrifti, St. John's-wort, Stæchas or French Lavender, Tanfy, Dropwort, Eye-bright, Bears-breech, Lavender, Agrimony, Scordium, Vervain-mallow, Marhmallow, Dill, Reft-harrow, Goats-rue, Germander, Thyme, Succory, Bafil, Orpine, Calamint, Ox-eye Daify, Vipers Buglofs, Marigold, Fluellin, Honeyfuckle, Ladies Bedftraw, Motherwort, Hedge Hyflop, Clove-gilliflower, Knot-grafs, Comfrey, Black Cherry, Dwarf Elder, Cudweed. Mezereon berries, Dodder, Garden Rocket, Hedge Muftard, Goofeberry, Water. Dock, Henbane, Maftich, Sweet Cicily, 
July. The Gardeners Kalendar. $\quad 235$ cily, Purflane, Rafpberry, Mother of Thyme, Mallow.

Work to be done in the GREEN-HOUSE, GARDEN and STOVE.

Gather the flowers of your Orange trees, where they are produced too clofe to each other; and where there was a fufficient number of fruit fet upon the trees the former month, it will be proper to diveft them of all the flowers which are now produced; for thefe being too late in the feafon, the fruits which fucced them, will not have time to grow to any confiderable fize before winter, fo will be in danger of falling off before fpring. You thould alfo obferve, where you may have overlooked fome bloffoms the laft month, which now are become fruit, to pull them off, leaving but few upon each tree, and thofe well fituated, and upon ftrong Thoots; for where there are too many fruit left upon the trees, it renders them weak: and the fruit, not having nourifhment, feldom grow to any confiderable fize, efpecially if the trees are in pots or tubs; and where they are upon weak thoots, they tarely come to any thing. 


\section{The Gardeners Kalendar. July.}

Continue to make cuttings of fuch exotick plants which are wanted for increafe, provided it was not done the preceding montlis. The beft method of planting cuttings at this feafon, is, to prepare a bed of light wich earth, into which the cuttings fhould be planted pretty clofe together; and then arch the bed over with hoops, covering the bed clofe with oiled paper to fhade them in hot weather; and obferve to water them duly when they require; but let them be expofed every night to reccive the dew, which will be of great ufe to them; but this is to be practifed only upon fuch forts of plants as are not very tender, becaufe the tender ftove plants will require a moderate hotbed to make them put out roots, efpecially the fucculent plants; fuch as Cereus, Euphorbiums, Cacius's, fome forts of Cotyledon, छc. but all the forts of Geraniums, Myrtles, seneci, Arctotus's, Hardy Apocynums, Melianthus, Sorrel tree, Leonurus, African Sage trees, Phlomifes, Hermannias, Amber tree, and other frrubs from the Cape of Good Hope, will take root much better in a bed of rich earth, than if planted in a hot-bed.

Shift fuch exotick plants as thave been raifed from feed's in the fpring, putting thena into feparate pots, and fuch as were feparated the 


\section{July. The Gardeners Kalendar. 237}

latter end of May, or the beginning of the laft month, which require larger pots than they were firft planted into, thould now be hifted again; but, unlefs they are fuch as grow faft, it will be beft to confine their roots, and not over pot them, for that will prevent their growth; then plunge fuch of them as are tender, into the hot-bed of tanners bark, obferving to water them and thade the glaffes, until they have taken new root; after which, they muft have air and water in proportion to the heat of the weather.

Waih and clean the leaves and tender thoots of the choice exotick plants from filth and infects, both which commonly infeft them at this feafon (efpecially thofe in the barkftove): which if not cleaned in time, the infects will fpread themfelves over moft of the other plants in the fame ftove, fo as not to be eafily deftroyed; and will not only render the plants unfightly, but greatly retard their growth.

In hot weather give the tender exoticks as much free air as pofible, efpecially when there is not much wind ftirring; and, in the midule of the day, it will be proper to thade the glaffes of the hot-beds where the glaffes are near the plants, when the fun is violently hot, otherwife 


\section{The Gardeners Kalendar. July.}

the earth in the pots will dry too falt: this mould alfo be practifed in fuch fmall ftoves, where the glaffes are near the plants; for in large airy ftoves, where the glaffes are at a diftance, they will not require hading, provided the glaffes are drawn down to admit a fufficient portion of air to the plants.

Stir up the tan of fuch beds whofe heat begins to decline, and add a little new bark to them, which will renew the heat, and caufe it to continue a confiderable time longer: at the fame time fuch plants as require it thould now be thifted, giving them larger pots, if their roots have been confined in their former pots.

The Ananas will now ripen very faft, if the feafon is warm : therefore when the fruit is cut from the plants, the pots with the old plants thould be plunged into a warm bed, to force out the fuckers early enough to take off before winter; in order to which, they Thould have their large leaves fhortened, and all the under leaves fhould be ftripped off, which will caufe the fuckers to pufh out very foon.

Where the Anana plants, which are to fruit the next feafon, have filled the pots with their roots, they may be now hifted into the pots they are to ftand in to bear fruit : by doing this fo early in the year, they will have time to make 
July. The Gardeners Kalendar. 239 make good roots before winter: for if they do not fill the pots with their roots before fpring, they feldom produce very large fruit. The tan-beds in which the Anana plants are placed for the next year, mould be kept in a good temperature of heat, but a large thare of free air fhould be admitted to the plants at all times when the weather is favourable.

Make layers of the Spanifh, Arabian, and Azorian Jafmines; as alfo of all the tender forts of Paffion flowers, which will eafier take root at the tender joints of the new thoots, than from the thoots of the former year : but you muft obferve to plunge the pots into which they are laid, in a hot-bed, efpecially of thore forts which are tender, otherwife they will not fucceed.

Gather all forts of exotick feeds as they ripen, and fpread them upon papers in a dry place to harden and dry; after which they thould be carefully preferved in their pods or hufks, until the proper feafon for fowing them.

Such of the tender annuals as will endure the open air, hould be now fet out of the hotbeds, in fome well-fheltered fituation, where feveral forts will produce feeds better than if kept conftantly in the beds. 
240 The Gardeners Kalendar. July.

Where any of the tender ftove plants are very much infefted with infects, or have contracted much filth upon their leaves, they thould be wathed clean, and expofed to the open air in a warm fituation, where they may be theltered from ftrong winds, which will be of great fervice to the plants; but when the plants are much infefted with infects, it will be proper to walh them with water in which there has been a good quantity of Tobacco ftalks fteeped, which will effectually deftroy the infects, where it is carefully applied, efpecially if the plants are in health. Some of the top glaffes of the ftove fhould alfo be conftantly drawn down every day in warm weather, for at this feafon moft plants perfpire freely; which, if pent up too clofe, will caufe them to look fickly, and occafion their leaves to change their colour, fo that infects will foon attack them.

Plants now in Flower in the Green-House, GAR DEN and S TOVE.

Oranges, Lemons, Limes, Citrons, and Shaddocks, Myrtles of feveral forts, Amomum Plinii, Barba Jovis or Silver-bufh, Ciftus Halimi folio, Ciftus Ledon three or four forts, Male 
July. The Gardeners Kalendar. $24 \mathrm{I}$ Male Ciftus of feveral forts, Spanin Jafmine, Geraniums of feveral forts, Tree Scabious of two forts, Yellow Indian Jafmine, Azorian Jafmine, Ilex-leaved Lantana, Warner's or Cape Jafmine, and Arabian Jafmine, Colutea EEthiopica, Afclepias of feveral forts, Blue and Scarlet Cardinal flowers, Caffias of three or four forts, Acacia Indica, Grewia, Senfitive and Humble plants of feveral forts, Coral tree, Lotus Argentea Cretica, Lotus Hæmorrhoidalis, Anonis two or three forts, Paffion flowers of many kinds, Coffee tree, White Spanifh Broom, Fabago with round and oblong fruit, Fabago with winged fruit, Wackendorfia, Othonna of two or three forts, Cape Phillyrea, Red and White Oleanders, Double Oleander, Sweet-fcented Oleander, Stapelea of three forts, feveral forts of Mefembryenthemi, Creeping Cereus, Large Upright Cereus, Hibicus of feveral forts, Cotyledons of feveral kinds, Ricinus or Palma Chrifti of feveral forts, Papaya, Iatropha or French and common Phyfick-nuts, Belly-ache weed, Cotton-plant, Bafella, Hæmanthus Colchici foliis, Double Indian Nafturtium, Minorca St. Johnfwort, Shrubby Polygala, Digitalis Acanthoides, Heliotropium of feveral forts, Gnaphaliums, Grafs-leaved Marigold 
242 The Gardeners Kalendar. July. from the Cape, Shrubby Marigold from the Cape, Shrubby African Branching Starwort with blue flowers, Lantana of five or fix forts, Phalangiums, Blue African Crinum, Olives, Tetragonocarpos, Rhamnus, Lyciums, Shrubby Perwinkle from India, Shrubby African Sage with blue flowers, Lentifus, Alues of feveral forts, Yucca, Indian-flowering Reed, Superb Lily, Turnera, Adhatoda two forts, Momordicas, Melon-thiftle, Quamoclit, Tamarind tree, Amber tree, Diofma three or four forts, Sorrel tree, Jacobæa Lily, Phytolacca Mexicana, Phytolacca Malabarica, Celaftrus of two forts, Wormwoud tree, Bermudiana Palmæ folio, Plumeria, Hedyfarums, Amaryllis, Broad-leaved Afphodel from the Cape, Pancratium of three forts, Crinum, Iris Uvaria, Rauvolfia, Piercea, Martynia three forts, Johnfonia, Phyllanthus, Spigelia, Chironia, China Agnus Caftus, Crotolarias, Waltheria, Climbing Dragon, Saururus, Coftus, Maranta, Kempferia, Clutia, Ceylon Leadwort, Lotus with black flowers, Ruellia of two or three kinds; Solanums of feveral forts, Phyfalis of feveral forts, Double Stramonium, Malpig-. hias, Maurocenia, Shrubby African Alcea, Perennial Tobacco, Canary Ox-eye Daify, African 


\section{July. The Gardeners Kalendar. 243}

African Doria with Orach leaves, Chryfocoma of two or three kinds, Bupleurum arborefcens, Caper-bufh, Craffulas, Anthericums, African Pafferina, Lavatera Africana frutefcens, Royenia, Shrubby Heliotropium of Peru, Shrubby Phytolacca of Perta, D'ayeńa, Ternatea, Kleinia two or three forts, with fome others.

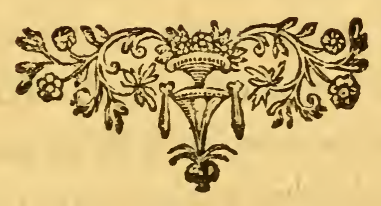

R2 AUGUST. 


\section{[244]}

\section{re?
A
$\mathrm{U}$
G
$\mathrm{U}$
S
T.

Work to be done in the KIтCHENGARDEN.

Feginning of this month you FI 2 (1) muft fow Onions, to fupply the (6) table early in the fpring for fal(2) lets, Ec. and, left the winter chould prove fevere, it will be proper to fow a few Wellh Onions at the fame time; for thefe will endure the greateft cold, when the common forts are frequently deftroyed; but thefe have a ftronger flavour than the common fort, which is the only reafon they are not fo much efteemed.

You muft alfo fow. Spinach, to fupply the kitchen in winter and fpring. The bet fort to endure cold, is the prickly-feeded kind, which is what moft people fow at this fea$\mathrm{fon}_{2}$ it being much hardier than the round- 


\section{Aug. The Gardeners Kalendar. 245}

leaved kind; of this there are two or three forts, which differ in the fize of their leaves; but the largeft and moft profitable fort is, what gardeners call the Burdock Spinach.

About the tenth or twelfth day of this month, you hould fow your early Batterfea and Yorknire Cabbage feed; for that which is fown earlier, will in mild winters frequently run to feed in the fpring: and if it is fown later than this time, the plants will not have ftrength to refift the cold, nor will they come fo early, provided they ftand through the winter, as thofe which are fown in this time.

The twenty-firft or twenty-third day of this month you thould fow fome Cauliflower-feed for the early crop, to be planted under bell or hand-glaffes, or clofe to fouth afpected walls where they are defigned to ftand open; there fhould alfo be fome more feeds fown about the twenty-fixth day for a fecond crop, to plant under frames to abide the winter; for it often happens, in mild feafons, that many of thofe plants, which were firft fown, run to feed in the fpring; for four or five days difference in fowing of thefe feeds, occafions great alterations in thefe plants; therefore, where there is not a fecond fupply, there will be a great difappointment when the firt mifcarry; befides, 
246 SThe Gardeners Kalendar. Aug. thefe will come to flower after the firft fowing is gone, fo that the table will be fupplied much Jonger with the fecond fowing, efpecially if the feeds which are laft fown are of a late kind of Cauliflower.

About the middle, or toward the end of this month, you fhould fow fome common Cabbage Lettuce, and fome Brown Dutch Lettuce, to be planted under frames to come early in the fpring; and part of the plants may be planted on warm borders without covering, which will live through the winter, provided it be not very fevere: you may alfo, toward the end of the month, fow fome Cos and Cilicia Lettuce, to plant on warm borders near walls, pales, or hedges, where, if the winter doth not prove fevere, they will live without any covering; and fome of thefe hould be left in the fpring upon the fame borders, which will be fit for ufe very early the following feafon, before thofe which are tranfplanted out from thefe borders, or from under frames: but where they are left, they thould not be too clofe together, nor too near the wall, becaufe they are apt to draw up weak, near walls, pales, or hedges.

In moift weather tranfplant Endive and Celery for blanching, which hould be well wa- 


\section{Aug. The Gardeners Kalendar. 247}

tered to fettle the earth to their roots; and if the weather hould alter to drought, they muft be duly watered until they have taken good root.

You may now tranfplant fome of the Letruces which were fown the former month, to fupply the kitchen in autumn: thefe fhould be planted in a warm fituation, left the frofts, which often happen early in October, Thould injure them: they muft alfo be duly watered until they have taken root.

Toward the latter end of the month you thould fow feveral forts of feeds, which remain a long time in the ground, which, if fown in the fpring, will often mifcarry; as Chervil, Angelica, Lovage, Mafterwort, Scurvy-grafs, Fennel, Alexanders, Sweet Sefeli, Corn fallet, and fome others, which always fucceed better when fown at this feafon, than when they are fown in the fpring.

Your beds of Coleworts, Ec. which were fown the laft month, hould be carefully weeded; and if the plants are very thick, fome of them thould be drawn out, and tranfplanted into another fpot of ground, that thofe which remain may have more room to grow.

Cut off the flowering branches of mont forts of aromatick plants, which are paft flowering; as Lavender, Rofemary, Savory, Hyffop, ${ }^{\circ} c$.

$\mathrm{R}_{4}$ that 


\subsection{The Gardeners Kalendar. Aug.}

that they may make new hoots before winter; but do not perform this work in very dry weather, for many times the plants are deftroyed by it, efpecially if they are cut too clofe, when there happens to be a long drought after.

Pull up Onions, Garlick, Rocambole, and Efchalots, when their leaves begin to wither and fall, and fpread them thin in an airy place to dry, before they are put up where they are to remain for winter ufe.

In dry weather you muft earth up your Celery, which is large enough, obferving not to bury the hearts of the plants, for that will rot them. You muft alfo tie up your Endive, which is full grown, or cover them with boards or tiles, to blanch; this muft alfo be performed when the leaves are very dry, otherwife the plants will rot.

Your Artichokes which were planted the laft fpring, will now begin to thew their fruit; therefore all fmall fuckers, which come out on the fides of their ftalks, Mould be cut off; for if they are permitted to remain on, they will weaken, and farve the top fruit; you fhould alfo clear them from weeds, or any other large growing plants, which ftand near them.

T:anfplant Broccoli (which was not planted out the former month) into the place where 


\section{Aug. The Gardeners Kalendar. 249}

it is to remain for flowering, obferving to water it duly until it has taken root. Thefe plants hould be planted in rows about two feet and a half afunder, and a foot and a half diftance from each other in the rows.

You may tranfplant fome Savoys, to come late in the fpring; but if the winter thould prove fevere, they will not grow to be large, nor will they cabbage fo well ; but in mild winters they often fucceed, and come late in the fpring.

Obferve to keep the Melons from too much wet, which many times caufes the plants to decay before the fruit is ripe; efpecially the Cantaleupe, and other curious forts, which are very impatient of wet; fo that, where they are treated in the common method, the plants generally decay before their fruit is ripe, fo are of no value.

The Cucumbers for pickling are now in feafon; therefore they thould be looked over twice or three times a week, to gather fuch as are fit; for, in a hort time, they will grow too large for that purpofe; thefe mult alfo be frequently watered in dry weather, which will caufe them to produce a greater quantity of fruit.

The 


\section{$25^{\circ}$ The Gardeners Kalendar. Aug.}

The Afparagus, which was planted the laft fpring, thould be carefully cleared from weeds; for at this feafon it will make new hoots, which will be much ftronger, where they are not injured by weeds, or other plants, than on the contrary.

All the winter crops, fuch as Parfneps, Leeks, Beets, Cabbages, $\Xi c$. fiould be conftantly kept clear from weeds, which, if fuffered to grow, will greatly injure them, and the weeds will foon fcatter their feeds at this feafon; whereby the ground will be plentifully ftocked with them, which cannot be rooted out in many years.

The dunghills hould alfo be cleared from weeds, particularly Chenopodii and Nighthade, which at this feafon are very common upon aimoft every dunghill; and if the feeds are permitted to fcatter upon the dunghills, when the dung is carried into the garden, the feeds will be mixed therewith, and thereby fill the ground with weeds; therefore they hould be pulled up, and caft into a heap, to rot at fome diftance from the garden or dunghill, or dried and burned; for if they are only hoed down, and permitted to lie upon the dunghill (as is by fome practifed), the feeds will ripen as they lie, and be almort as bad as if they had been fuffered to grow to maturity. 


\section{Aug. The Gardeners Kalendar. $25 \mathbf{r}$}

You may, in this month, plant lips of Sage, Rofemary, Stæchas, Lavender, Maftich, and other aromatick plants, where it was omitted in the fpring; but thefe will not be near fo ftrong, nor fo capable of refifting the cold of the next winter fo well, as thofe planted in the fpring; therefore will require to be Theltered, if the winter fhould prove fevere.

Cut fuch herbs as are now in flower to diftil, or to dry for winter ufe, always obferving to do it when they aredry, and hang them up in a dry hady place; for if they are dried in the fun, they will Thrink up, turn black, and be of little worth.

Continue to fow the feeds of Creffes, Rape, Turnep, Raddifh, Muftard, and other kinds of Sallet herbs, every week, that the table may not be unfurnifhed, for thefe forts foon grow too large for ufe at this feafon.

Gather all forts of kitchen-garden feeds, which are now ripe, fpreading them upon mats to dry; and then beat or rub them out of their hufks or pods, and put them up till the feafons for fowing them.

The Raddifh feed, which is now in pod, muft be guarded, to prevent the birds from devouring it, which they will do in a Thort time, if they are not continually watched. 


\section{The Gardeners Kalendar. Aug.}

Sow Turneps for a latter crop, which may be done any time before the twentieth day of this month; but thofe which are fown later, feldom apple well, efpecially if the autumn proves cold.

Earth up Finnochia, which is full grown, to blanch it, that it may be fit for ure; and continue to tranfplant Celery into drills, that there may be a fucceffion to fupply the table through the feafon.

The Spinach which was fown the end of the laft month for winter ufe, will now be fit to boe, which fhould be performed in dry weather, that the weeds which are cut may be foon killed; for in moift weather, they will take root again, fo will require another cleaning. At this time the Spinach thould be cut down, where it grows too clofe; for the plants thould not be left clofer to each other than three inches, that they may have room to fpread, and produce large leaves, in which the goodnefs of winter Spinach confifts.

Products of the KITCHEN-GARDEN.

Cabbages, Kidney Beans, feveral kinds of Peas, Artichokes, Garden Beans, Carrots, Cabbage Lettuces of feveral forts, Finnochia, Celery, 


\section{Aug. The Gardeners Kalendar. 253}

lery, Turneps, Cucumbers, Melons, Onions, Purlane, all forts of young fallet herbs, fome late Cauliflowers, Endive, Sorrel, Baum, Burnet, Marigolds, Beet, Spinach, Potatoes, Mufhrooms, Tomatos, Bafil, Thyme, Savory, Marjoram, Clary, Mint, Sage, Rofemary, Lavender, Hyffop, Capficums for pickling, Cucumbers for pickling, large-rooted Parlley, Fennel, Dill, Sprouts from Cabbage ftalks, Card Beet, Cicers, Raddifhes, Scorzonera, Horfe-raddin, Nafturtium Indicum, the flowers for fallets, and the feeds for pickling; Pumkins, Gourds, Parfneps, and fome other forts.

Work to be done in the FRUIT-GA'R DEN, and VINEYARD.

Look carefully over the wall-fruit trees, to deftroy fnails and other vermin, which will gnaw the choice fruits, and fpoil them. You thould alfo deftroy fparrows and tomtits, which will peck your choice Pears, Figs, and Grapes, as faft as they ripen, where they are not defended; and where it was not done the former month, you hould fix fome phials with honeywater on different parts of your trees, to deftroy the wafps, which will drown themfelves by attempto 
254 The Gardeners Kalendar. Aug. attempting to drink of the water. Thefe phials hould be fixed before the fruit begins to ripen, when the warps and flies will be much fooner inticed to the water, than they will after they have tafted the fruit: fo that by the timely ufe of this method, the fruit may be preferved.

Where any branches of the trees project from the wall, or have been difplaced by winds, Ec. they hould be carefully faftened to the wall in their due pofition, that the fruit may receive the benefit of the fun to ripen it ; but do not pull off the leaves of the trees (as is by fome perfons practifed); for this expofes the fruit too much, whereby it becomes hard, and feldom ripens kindly, efpecially when it is done long before the fruit is ripe.

The Vines in the vineyard, and thofe againft the walls, hould now be gone over for the laft time, pulling off all trailing branches which have been lately produced; and faften thofe branches which are loofe in their proper places, that the fruit (which is now full grown) may receive the benefit of the fun and air to ripen it. Ycu mould alfo obferve to keep the ground clear from weeds between the rows of Vines, that the fun may dry up the moifture of the ground every day; fo that the reflection of heat may be greater to ripen the fruit. 


\section{Aug. The Gardeners Kalendar. 255}

Untie the buds of fruit trees, which were inoculated the laft month; otherwife their bandage will pinch the bark of the ltocks, and prevent their growing equally in the part where the bud is put in: you fhould alfo obferve to clear the lower part of your ftocks from thoots where any are produced, and keep the ground clear from weeds, near the roots of your fruit trees.

\section{FRUITs in Prime.}

Apples; the Summer White Couftin, Margaret Apple, Codiin, Summer Pearmain, Summer Pippin, and fome others.

Pears; the Jargonelle, Windfor, Cuiffe $\mathrm{Ma}$ dame, Orange Mufk, Grofs Blanquette, Mufk Blanquette, Long-ftalked Blanquette, Poir fans peau, Mufcat Robine, Amber Pear, Green Orange, Caffolette, Magdalen Pear, Gros Oignonet, Poir Rofe, Summer Boncretien, Cailot Rofat, Petit Ruffelet, with fome others of lefs note.

Peaches; Red and White Magdalen, Early Newington, the Mignonne or Minion, Italian Peach, Nobleft, Bellows or Bellis. Violette Hative, La Chevreufe or Belte Chevreufe; Early Admirable, Albermarle, Nivette teach, 
256. The Gardeners Kalendar. Aug. Montaubon, Royal George, Purple Alberge, Chancellor, Bourdine, with fome others.

Nectarines; Roman Red, Elruge, Newington, Brugnon, Italian, and Murray.

Plums; Orleans, White Perdrigon, Violet Perdrigon, Rea Imperial, White Imperial or Bonum Magnum, Le Royale, Cheftun Plum, Drap d'Or, St. Katharine, Roche Courbon, Reine Claude, commonly called in England Green Gage, La Mirabelle, Apricot Plum, Prune Monfieur, Maitre Claude, Royale Dauphin, with fome others.

Grapes; the July, White Sweet-water, Black Clufter, Munier, Chaffelas, White Mufcadine, White Frankindal, Black Sweet-water, and Orleans.

Figs; the early White, Long Blue, Long White, Black Ifchia, Brown or Chefnut Ifchia, Large Yellow Ifchia, Green with white flefh, Green with purple flerh, and Green with red fleh, Brunfwick, Malta, Black Naples, and Cyprus Fig.

Filberts, Nuts, Mulberries, Alpine Strawberry, Goofeberries, Currants, Black Cherry, Hertfordhire Cherry, Amber, and Morello Cherries; Melons, and, in the ftove, the Anana or Pine Apple, and the Mufa. 


\section{Aug. The Gardeners Kalendar. 257}

Work to be done in the NURSERY.

The beginning of this month you thould look carefully over the ftocks which were budded the laft month, and loofen the bandage, left the buds fhould be pinched thereby: and where there are any thoots produced below the buds, they fhould be cut off. You thould alfo look over your trees which were budded the former year, or grafted in the fpring, cutting of all fuch hoots as are produced below the place where they were budded or grafted; for if thefe are permitted to grow, they will ftarve the buds or grafts.

Keep your ground clear from weeds between your trees, and train up the feveral forts of Evergreens, foreft trees, and Mrubs, for the feveral purpofes they are defigned; but do not trim the ftems of ftandard trees too clofe; for if they have not fome fmall thoots left on the fides of their ftems, to detain the fap to ftrengthen the ftems, they will not be able to fupport their heads.

You fhould, toward the end of this month, begin to clear and trench the ground, where you intend to plant out Atocks, or young foreft trees in autumn, that the rain may foak and mellow the ground before the feafon of plant. 
258. The Gardeners Kalendar. Auge ing; and if your land is ftiff, the laying of it a month or fix weeks in ridges, before it is planted, will mellow the clods, and render them much eafier to be broken, than if it was newly dug.

Look carefully to your young feedling trees, to obferve that they do not fuffer by drought, nor that they are over-borne by weeds, which, at this feafon, do foon get up to a confiderable height.

Work to be done in the PLEASURE-GARDEN.

Tranfplant the layers of Carnations, Pinks, and double Sweet Williams, which by this time will have taken root, if timely laid. Thofe choice forts of Carnations, which are defigned for pots, may be planted at this time, each in a fmall halfpenny pot, filled with freth light earth, and placed in a Mady fituation until they have taken root; after which they may be removed into a more open fituation, where they may remain until the end of October, when they mould be placed under a hot-bed frame; or plunged into an old bark-bed without heat, and arched over with hoops, that they may be covered in winter, to protect them from hard rains, fnow, and fevere froft; but they hould be always opened in mild weather, otherwife 
Aug. The Gardeners Kalendar. 259 they will draw up weak. In this manner they may be much better preferved, than if they were planted out at firf into the pots where they are to remain for blowing, becaufe they will ftand in a fixth part of the compafs; and in the fpring they may be turned out of the fmall pots with the earth to their roats, whereby they will not receive any check, and placed into larger pots to flower. But thofe Carnaticns, Pinks, and Sweet Williams, which are defigned for the borders of the pleafure-garden, hould be now planted in beds in the flowernurfery, to remain till the middle of October, when you mult dig the borders of the pleafuregarden, and new plant them: at which time thefe may be taken up with a ball of earth to their roots, and planted in the borders with other flowers.

You may now thift your choice Auriculas into freeh rich earth, obferving to clear them from dead leaves, and place them in a fhady fituation until they bave taken root: this frefn earth will frengthen the plants greatly, and improve their flowers the following fpring.

You may yet remove the roots of bulbous Irifes, Fritillarias, and Hyacinths of Peru; and alfo the roots of Lilies, Martagons, Crown Imperials, Pwonias, and Flag Irifes, whofe leaves 


\section{The Gardeners Kalendar. Aug.}

are now decayed; but if fuffered to remain much longer in the ground unremoved, many of the forts will puh out freh fibres, when it will be too late to remove them; but efpecially white Lilies, becaufe they foon put out new leaves; after which time, if they are removed, they rarely flower the following feafon.

Gather all forts of flower feeds as they ripen, and fpread them to dry in the fun; after which they thould be preferved in their pods or hufks, until the feafons for fowing them ; for the feeds. of moft plants may be kept longer good in their pods, than when they are rubbed out.

Tranfplant Polyanthufes, Primrofes, and feedling Auriculas, obferving to thade and water them until they have taken root, as alfo to clofe the earth to their roots, otherwife the worms will draw them out of the ground; to prevent which, fome perfons make a bed of cold dung, beating it down very clofe, then lay good earth thereon, three or four inches thick, and plant their feedling Auriculas into it: this dung keeps down the worms, and preferves the plants from being turned out of the ground.

Cut down the ftalks of fuch plants as have done flowering, and are decayed; and faften all tall-growing plants to fticks, to fupport them 
Aug. The Gardeners Kalendar. 26I from being broken or blown down by frong winds, which often reign at this feafon.

The pots of annual plants muft now be duly watered in dry wcather, otherwife they will forn lofe their beauty; and fuch of them as are tender thould be removed into thelter when the nights begin to be cold, that they may perfect their feeds; which in bad feafons feldom ripen well, if they are not proteched from the inclemency of the weather, particularly the Double Stramonium, Double Balfamine, Quamoclit, Deep blue Convolvulus, with fome other tender forts.

Toward the latter end of this month you mould begin to prepare your beds to receive your choice Hyacinths, Tulips, and Ranuculufes, that the earth may fettle before the roots are pianted; otherwife, when the earth finks unequilly, there will be holes on the tops of the beds, which will detain the water, whereby the roots in thofe places will be rotted. If thefe beds are made three feet deep, and forne very rotten neats dung laid in the bottom, the fibres of thefe roots will frrike down into it in the fpring; and, receiving great nourihment from the dung, it will caufe them to flower very frong; but the earth of thefe beds should not be fcreened very fine, but only the larger

$$
s_{3}
$$


$26_{2}$ The Gardeners Kalendar. Aug: ftones fhould be raked out, and all the clods well broken; for wien the earth is fcreened fine, it is very apt to bind in winter.

Clean all the parts of your flower-garden from weeds; which if permitted to ftand, will Thed their feeds in a thort time, whereby your garden will be fo ftocked with weeds, as not to be rooted out in feveral years.

You may now fow the feeds of Anemonies, Pulfatillas, Ranunculufes, Crocufes, Fritillarias, Hyacinths, Tulips, Narciffufes, Cyclamen, Irifes, Auriculas, Lilies, Martagons, Polyanthufes, $\mathcal{E}^{2} c$. in pots or boxes filled with light rich earth, obferving not to cover thofe feeds which are thin and light, too deep; for thefe will rot in the ground when buried deep, efpecially the Raunculures, Pulfatillas, Anemonies, Auriculas, Polyanthufes, and Fritillarias; but the larger feeds may be covered thicker. Thofe pots or boxes Arould be placed where they may have the morning fun till ten or eleven o'clock; for if they are too much expoled to the heat of the fun at this feafon, the feeds will not fucceed fo well : they muit alfo be frequently refrefhed with water, but it fhould be given very gently, otherwife the feeds will be in danger of being wafhed out of the ground. 
Aug. The Gardeners Kalenaiar. $\quad{ }^{2} 6_{3}$

The feeds of feveral kinds of annual flowers may now be fown on warm borders to ftand the winter, that they may flower early the following fummer, whereby they will be much ftronger, and produce a greater quantity of flowers, than thofe which are fown in the fpring, and their feeds will conftantly ripen better. Of thefe are the S'weet Pea, Venus Navelwort, Dwarf Annual Stock, Lobel's Catchfly, Xeranthemums, Sweet Sultan, Cerinthe of three or four forts, Myofotis, Chryfanthemum, Adonis, Meadia, Cape Horn Pea, Indian Scabious, and moft forts of umbelliferous plants.

You may now propagate the Double Scarlet Lychnis, Double Rofe Campion, Double Rocket, Gentianella, Double Ragged Robin, Batchelors Button Red and White, Double Catchfly, and Canada Leonurus, by flipping and parting of their roots ; but thefe lips fhould be planted in fhady borders, or otherwife they muft be duly fhaded every day in dry hot weather with mats, and conftantly fupplied with water, until they have taken root: thefe llips will make very good plants (provided they are carefully planted and duly watered) by the beginning or middle of October; when they may be either planted into pots, or the borders of the flower-

$$
\mathrm{S}_{4} \text { garden, }
$$


264, The Gardeners Kalendar. Aug. garden, where they will flower ftrong the following feafon.

The pleafure-garden muft now be duly looked after, to keep it neat; for in moift weather the grafs muft be frequently mowed, rolled, and polled, to have it fine; the gravelwalks muft alfo be kept clean from weeds, and çonftantly rolled, and as the leaves of trees will often begin to fall at this time, fo they hould be daily fwept up to have the whole garden decent.

Plants now in Flower in the PIEASUREG A R DEN.

Some Carnations, Painted Lady Pink, Oldman's-head Pink, Female Balfamine, Marvel of Peru, Amaranthufes, Gomphrenas, feveral forts of Starwort, Golden-rods of feveral kinds, Scarlet and Biue Cardinal's flower, Campanula of feveral forts, Hollyhocks, Colchicum of Chio, Autumnal Cyclamens, Greater Convolvulus of feveral forts, Flos Adonis, Venus Lookinglafs, Venus Navelwort, Africans, and French Marigold, Sweet Sultans, Indian Scabious, Nigellas, Candy Tuft, Apocynums, Sweet Pea, Tangier Pea, Everlating Peas, Sunflowers of many linds, Lavateras, Mallows of feveral forts, 
Aug. The Gardeners Kalendar. $\quad 265$ Linarias, Centaurias, Ketmia Veficaria of four kinds, Stramoniums, Tuberofes, Sclareas, Geraniums, Lychnifes, Annual Stocks, Blattaria lutea, Double Ptarmica, Xeranthemums, two forts of Marigolds from the Cape of Good Hope, Onagras, Lyfimachias, Veronicas, Autumnal Hyacinth, Globe-thifles, Dwarf annual Stock, Nafturtium Indicum, Fairchild's Mule, Virgian Spiderwort, Catanance quorundam, Catanance flore luteo, Elichryfum Americanum, Stæchas Citrina, Double Feverfew, Coronilla herbacea, Chryfanthemums, Eryngiums, Glauciums, Afclepias or Swallow-wort with white, yellow, and black flowers, Periplocas, Capnoides, Aconitum lycoctonum luteum, Aconitum falutiferum, Napellus cœruleus, Alceas, Helianthemums, Double Sopewort, Argemone Mexicana, Antirrhinums, Lupines of feveral forts, Lavendula folio diffecto, Iris Uvaria, Cerinthe with purple and yellow flowers, Perficaria Orientalis, Phyfalis of feveral forts, Limoniums, Dracocephalum, Molucta lævis \& Spinofa, Solanums of various kinds, Melongena, Hedyfarums, Phalangiums, Oriental Buglofs, Alyffums, Ambrofia of three forts, Bafil, Capficum, Palma Chrifti, Tobacco, Clinopodium Virginianum, Commelina, China Starwort with fingle and double red, blue, and white flowers, 
266 Tise Gardeners Kalendar. Auĝ. flowers, Monarda of three forts, Trachelium Umbelliferum, Convolvulus minor with white, blue, and ftriped flowers, Hawkweeds of divers forts, Purple Senecio, feveral forts of Anonis, fome forts of Afragalus, Canary Lavender, Sherardia, Echiums, Globularia, Collinfonia, Poliums, Spigelia, Lychnideas, Perennial Blue Lupine, Eupatoriums, Dianthera, Rudbeckia of feveral forts, Ruyfchiana, Acanthus, Cirfiums, Greater Centuary, Carthamus, Glycine, Perennial Fumitories of feveral forts, Gnapha. liums, Lunarias, Chryfocoma, three or four forts of Bupthalmum, Zinnia, Gaura, Orobirs, Tragopogon of two or three forts, Scorzonera, Bifferula, Clitoria, Hibifcus of feveral forts, Hæmanthus, with fome others.

\section{Hardy Trees and Sbrubs now in Flower.}

Common White Jafmine, Paffion flower, Pesiploca, Scorpion Sena, Shrubby Althæa of feveral forts, Agnus Caftus, Honeyfuckles, Mallow tree, Shrubby Canary Hypericum, Stinking Shrubby Hypericum, Lauruftinus, Double Virgins-bower, Bignonia or Trumpet-flower, Angelica tree, Magnolia or Laurel-leaved Tulip tree, Traveller's-joy, Mufk Rofe, Bladder Sena of three forts, Spanin Broom, Ciftufes 


\section{Aug. The Gardeners Kalendar. $\quad 267$.}

tufes of feveral kinds, Phlomifes, Celaftrus, Sumach of feveral forts, Double and fingle Pomegranate, Cytifufes of three or four forts, Catalpa, Clethra, Itea, Diervilla, Hydrangea, Lotus of two or three forts, Spireas, Prinos, feveral forts of Dyers-broom, Tamarif, Medicago frutefcens, Periclymenum Virginianum, Azalea, Kalmia, Rhododendron, Andromeda, Azederach, Kidney-bean tree, Cannioberry buhh, Thymelea, Toxicodendron, Spartiums, Geniftas, with fome others.

Medicinal Plants which may now be gatbered for Ufe.

Bear's-brech, Vervain-mallow, Garlick, Dill, Nightihace, Bihopfweed-feed, Love-apple, Vervain, Goofeberry, Arum or Cuckow-pintleroots, Italian-Starwort, Yellow Starwort, Golden Rod, Bafil, Summer Savory, Briony-berries, Navew-ronts, Honeyfuckle, Capficum or Indian Pepper, Safflower, Knot-grafs, Netilefeed, Onion-feed, Fleawort, Cornelian Cherry, Coriander-feed, Carrot-feed, Endive, Arfefmart, Jafmine-flowers, Glaffwort, Lupine, Marjoram, Tobacco, Poppy-heads, Stœchas or French Lavende:, Thorn Apple. 


\section{The Gardeners Kalendar. Aug.}

\section{Work to be done in the GREEN-HOUSE, GARDEN, and STOVE.}

About the beginning of this month you may inoculate Orange trees, obferving to turn that fide of the ftock where the bud is put in, from the fun. Cut off Oranges, Jafmines, and other exoticks, which were inarched the former fpring, from their mother-trees, being careful in the cperation, no to loofen the graft from the ftock, nor hould the clay or wax be rubbed cfir until the following fpring.

The beginning of this month is a proper feafon for thifting Aloes, Sedums, Mefembryanthemums, Cereufes, Euphorbiums, and other exotick fucculent plants, which now are in full growth, fo will take root again fooner than at any other time of the year : you hould at the fame time take off the offsets of your Aloes, and plant them into fmall pots filled with freln fandy earth, placing them where they mav have the morning fun, obferving to refrefh them now-and-then with a little water in dry weather; which if duly obferved, there will be no occafion to give them any artificial heat to encourage them to take root, for at 
Aug. The Gardeners Kalendar. $\quad 269$ this feafon they are greatly difpoled to fend forth roots.

The feveral kinds of tender exotick plants, which are conftantly preferved in the barkftoves, hould now be thifted, that they may make ftrong roots before winter; for if they are Mifted too late in the feafon, they do not recover it before the cold comes on, which checks their growth, fo that they will not appear fo vigorous, nor will they be fo ftrong to maintain themfelves in winter; but if they are not hifted at this feafon, their roots will be fo matted in the pots that they will grow mouldy in winter, and decay; which has often been defructive to many choice plants.

The beds in which the Ananas are placed, Thould be now refrethed with fome new tanners bark (provided it was not done the former mionth); for the evenings, toward the end of this month, often begin to grow cold; and if the heat of the beds alfo decline, the plants will receive a check; and this being the principal feafon of their growth, it will prevent their ftrengthening themelves for fruit the following year, nor will the heads of offsets which have been newly planted, be fufficiently furnifhed with roots before winter, if the beds are not kept in a kindly temperature of warmth; and, 


\section{2 yo The Gardeners Kalendar. Aug.}

as the nights grow cold, the glaffes thould be covered with mats, to keep them warm: but thofe plants which are defigned to fruit the next year, fhould not be too much forced at this feafon, efpecially thofe which are forward, left it Mould drive them into fruit in the winter, which is often the cafe: and even the fuckers, taken off early the fame feafon, are fometimes forced into fruit a year too foon, when they are kept too hot, or by receiving a great check in their growth. Thofe plants which are to produce fruit the following year, fhould now be Mifted into the pots, where they are to re-, main, if it was not done in July; for if they are difturbed later in the feafon, they will not have time to make good roots before winter. This is to be underftood of fuch plants as are defigned to fruit in the pots: for thofe which are to be planted in the tan in autumn, Mould not be difurbed at this feafon; for they muft never be tranfplanted after they thew their fruit, as that will grearly retard them, and caufe their fruit to be fmall.

The feveral kinds of hardy green-houfe plants thould now be Mifted, and thofe which require it must have larger pots; for if their roots are too much confined, and matted about the pots, they will grow mouldy and decay. 


\section{Aug. The Gardeners Kalendar. $\quad 27 \mathbf{r}$}

When they are fhifted, they hould be placed in a Mady fituation, until they have taken freh root; after which they may be expofed again to the fun, until the time of houfing them: but you fhould not expofe them too much to ftrong winds, which will blow them out of the pots again, when they have been lately removed, unlefs they are fupported by fakes.

You hould now talse fome of the earth out of the tubs or pots of Orange trees, filling them up again with rich freh earth, which will encourage them to funport their fruit in winter.

Wanh and cleanfe the leaves and ftems of your Coffee trees, and other exotick plants, from filth, which they are very fubject to contract at this feafon; and if it be not cleaned off, will entice vermin, to the great injury of your plants.

Towards the latter end of the month, you may remove your Cereufes, Euphorbiums, and other very tender fucculent plants, which have been placed abroad, into the ftove again; for, at this feafon, the nights begin to grow cold, and there often happens much rain; which is very injurious to thefe plants, when they are expofed thereto; but if the feafon is warm, they may continue abroad a fortnight longer. 


\section{The Gardeners Kalendar. Aug.}

Plants in Flower in the GREEN-HOUSE and $\mathrm{S} \mathrm{T}$ OV $\mathrm{E}$.

Geraniums of feveral kinds, Mefembryanthemums of various kinds, Stapelea, feveral forts of Aloes, Sedums, Cotyledeons, Myrtles, Oranges, Ciftufes, Colutea Ethiopica, feveral forts of Paffion flower, Senfitive Plant, Humble Plant, Indian Figs, Oleanders, Alceas, Ketmias of feveral forts, Hæmanthufes, Cardinal flower, Egyptian Sea Lavender, Leonurus minor, Aretotufes, St. Johnfwort of Minor$\mathrm{ca}$, Iatropha of feveral forts, Quamoclit, Spanifh Jafmine, Arabian Jafmine, Azorian Jafmine, Indian Yellow Jaimine, Laurel-leaved Jarmine, Apocynums, Acacias, Sena Alexandirina, Cafias of feveral forts, Hedyfarums, Elichryfums, Indian Nafturtiums with a double flower, Ragwort, Dorias, Senecio folio retufo, Canna Indica, Fabagos, Trachelium umbellatum Azurium, Limonium Afplenii folio, $\mathrm{Li}$ monium Siculum Gallas ferens, Turnera, Convolvulufes of feveral forts, Plumeria, Phytolacca, Piercea, Poliums, Solanums, Lotus argentea Cretica, Martynia, Indian Arrow root, Ceftrums, Bafella, Cotton plant, Indico plant, Guava, Coftus Arabicus, Eupatoriums, Buph-

thalmuras, 
Aug. The Gardeners Kalendar. 273 thalmuḿs, Papaya, Conyzas, Cereufes, Euphorbiums, Melon Thiftles, Diofma of three forts, Blue flowering Sage from the Cape, Crinum, Pancratiums, Limodorum, Kempfera, Clitoria, Spigelia, Pafferina, Royenia, Arum fcandens, Waltheria, Polyanthes, Sida, Caper, Chironia, China Chafte tree with cut leaves, feveral forts of Ricinus, Crotolarias, Anonifes, Malpighia, Cacalia two or three forts, Grewia, Volkhameria, Black flowering Lotus, Milleria, Guanabanus, Cornutia, Tournefortia, Polygala, Hermannias, Saururus, Plumbago, Wackendorfia, Ambrofia from Peru, D'Ayena, Shrubby Heliotropium of Peru, Blue branching Starwort from Africa, Erhetia, Robinia, Tradefcantia, Commelina, Wormwood tree, Canary Convolvulus, Shrubby Convolvulus, Bignonias, Lantana of feveral forts, Sorrel tree, Toxicodendron, Craffulas, Cyanella, with fome others.

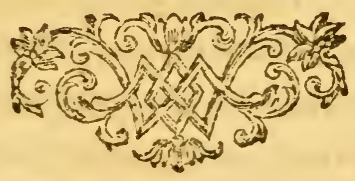




\section{[274]}

Ca ky

\section{S E P T E M B E R.}

Work to be done in the KITCHEN$G A R D E N$.

porcosern $\mathrm{HE}$ middle of this month you (1) W. and and upon old Cucumber or Melcn-beds; for if they are put upon beds without any dung under them, the worms will draw them out of the ground; but if the feafon proves cold, and the plants are backward, it will be proper to make a llight bed with warm dung, which will bring them forward: the diftance which thefe plants thould be allowed in thefe beds is three inches from row to row, and about two inches afunder in the rows, which will be fufficient room for them to grow till toward the end of October, which is the time when they mut be 
Sept. The Gardeners Kalendar. 275 tranfplanted again into their winter-beds, or in rows to be covered with bell or handglaffes.

Toward the middle of this month, you muft fow fome feeds of Cos, Cilicia, and Brown Dutch Lettuces, to plant under frames or handglafles, which may be covered in fevere froft; fo that if thofe on the warm borders are deAtroyed, thefe may be preferved: and if thofe thould efcape, thefe will come after them, and the table may be better fupplied.

The Cardoons which were planted out in June, fhould now be earthed up; in doing of which, you muft carefully tie up their leaves with an hay-band; then lay the earth up to each plant, about eighteen inches high, being careful not to bury their hearts. This worls Thould always be performed in dry weather.

You may now make Mufhroom-beds; in doing of which, you muft obferve to make choice of fuch dung as hath lain about three weeks or a mouth on an heap, whereby its. great heat is loft; nor thould the dung, intended for this purpoie, be thrown on a heap to ferment, as is the practice for hot-beds; becaufe if it ever is violently hot, it will not take the fpawn of the Mufhrocms near fo well, as that dung which has not been much ferment- 
276 The Gardeners Kalendar. Sept. ed, which is the reafon why fome perfons prefer the dung of ftone horfes to that of other animals; and let your knobs of fpawn be laid to dry in a hady place a fortnight, before you put them into the bed. The particular directions for making of thofe beds may be feen in the Gardeners Dictionary.

Hoe and clean Turneps; and the Spinach which was fown the laft month, from weeds, cutting out the plants where they are too clofe; obferving, if poffible, to do this in dry weather; otherwife the weeds will take root again, and be very troublefome. You hould alfo weed the beds of Onions, Carrots, Cauliflower, Cabbage plants, and Coleworts, which were fown the laft month; for if the weeds are permitted to grow, they will foon over-top the plants and fpoil them.

Earth up your Celery as it advances in height, obferving ajways to do it in dry weather; and be careful not to earth it above the hcarts of the plants, becaufe that would prevent its growing tall, and many times occafion its rotting.

The middle of this month you may fafely cranfiant moft forts of perennial aromatick plants; as Rofemary, Lavender, Stcechas, E̋c. which will take root again before the front 
Sept. The Gardeners Kalendar. 277 comes on to prevent them; but this hould be done in moif weather.

Continue to fow fmall Sallet herbs; fuch as Radih, Turnep, Creffes, Muftard, Chelvil, Eंc. but as the cold increafes, they fhould have a warmer fituation, otherwife the morning frofts will loofen the ground, and thereby turn their roots, out to the air, whereby they will be deAtroyed.

Gather all forts of feeds as they ripen, and fpread them to dry upon mats or cloths; and then beat them out of their hufks, and put them up in a dry place, uniil the feafons for fowing them.

In moif weather you may tranfplant your Colewort plants, which were fown in July, into the places w:here they are to remain till fpring; and you hould aifo tranfplant your Cabbage plants which were fown the beginning of Augurt, that they may acquire ftrength before they are planted out for good.

Tranfplant fome of your late fown Endive on borders under warm walls, pales, or hedges, to ftand till February before it is blanched; and in dry weather tie up fuch Endive as is full grown, to blanch it for ufe; or if the plants are covered clofe with tiles or boards, they will blanch equally well. 
278 The Gardeners Kalendar. Sept.

If the feafon hould prove dry, you hould water your laft crop of Cauliflowers, which are to come the next month; otherwife their heads will be very fmall, efpecially if the ground is dry.

Continue to keep all your late crops clear from weeds; for if they are not well cleaned before the great rains of autumn fall, it will be difficult to deftroy the weeds afterward; for, at this feafon, the weeds are generally produced in pienty.

Toward the latter end of this month you Ihould tranfplant Lettuces of feveral forts upon warm borders, where they may remain to cabbage early in the fpring; but you may plant them pretty clofe together at this feafon, becaufe, if they live through the winter, part of them may be tranfplanted out in the fpring into an open fpot of ground, where they will grow larger than thofe left in the border, but will not be fit for ufe fo foon by a fortnight o: three weeks; which is an advantage, in having them continue fo much longer to fupply the table.

At the end of this month you may cut down the haulin of Afparagus which is beginning to wither, and clear the weeds off from the beds into the alleys where they hould be buried, 
Sept. The Gardeners Kalendar. 279 and the earth of the alleys thould be laid upon the beds to new mould them; and where the beds want dunging, there thould be fome very rotten dung taken out of old Cucumber and Melon-beds, and laid upon the Afparagus-beds, after the weeds are hoed off, and then the dung covered over with part of the earth from the alleys.

If there hould happen much rain at this feafon, your young Cauliflower plants muft be protected therefrom; otherwife it will caufe their ftems to turn black, and the outer fkin will decay in a thort time. This is what gardeners term black hanked.

Moft of your fummer crops being intirely cleared from off the ground, you hould, in dry weather, hoe and clear the ground from weeds, which will preferve it neat and clean until you thall prepare it for frem crops, o: trench it up to lie till fpring; the fuffering of weeds to grow after the crops are taken off the ground, impoverifhes it, though the weeds are not fuffered to feed.

At the end of this month you may plant fome Beans, and fow fome early Peas, in warm borders; where, if they abide the winter, they will produce their-crops early the fucceeding spring.

$$
\text { T4 Tranf }
$$


280 The Gardeners Kalendar. Sept. Tranfplant your latter crop of Celery into drills, which, at this feafon, hould always be planted on drier ground than the former crops; for as this is to remain till the fpring, fo it will be in danger of rotting on a very moift foil.

You fhould now tranfplant the laft crop of Broccoli where it is to remain, that it may acquire ftrength before the froft comes on to check it; and you hould draw earth up to the ftems of your former crops, which will greatly protect them from the froft.

There may now alfo be fome Carrot feeds fown upon warm borders, where, if they furvive the winter, they will come early in the fpring, whereby the tabie may be fupplied with young Carrots for a month or fix weeks, before thofe which are fown in the fpring will be fit for ufe.

The Carrots which were fown in the frelds for feeding of ftseep, or deer, Eंc. mould, toward the end of this month, be drawn out of the ground and houfed, to preferve them; thefe hould lie four or five days to dry, then they thould be properly ftacked up in a good dry barn, with dry fand laid between them to prevent their rotting, and when hard froft comes on they thould be covered with ftraw or dried fern, to prevent their being fro- 
Sept. The Gardeners Kalendar. 28 zen; where this is practifed, thefe roots will be an excellent winter and fpring pabulum for moft fort of cattle.

\section{Products of the KITCHEN-GARDEN.}

Cabbages, Carrots Artichokes, Parfneps, Potatoes, Shallots, Onions, Leeks, Garlick, Celery, Endive, Cabbage Lettuce of feveral forts, Scorzonera, Salfafy, Mufhrooms, Cucumbers for pickling, Melons, Kidney Beans, Rouncival Peas, Marrowfat Peas, Garden Beans planted late, Beets, Turneps, Radihes, large rooted Parlley, Black and White Spanin Radifhes, Sprouts from the early Cabbage ftalks; and, for Soups, Chervil, Sorrel, Tomatos, Gourds, Squarhes, Burnet, Cardoon, Chard Beets, Parley, Origanum; as alfo Thyme, Bafil, Marjoram, Hyfop, Winter-favory, and all forts of young Sallet herbs.

Work to be done in the FRUIT-GARDEN.

Your fruits hould now be gathered as they ripen, for thofe which are in eating this month feldom continue long good; but toward the end of the month, fome forts of winter fruit will be fit to gather; but you hould always fuffer them to remain as long upon the trees as 
282 The Gardeners Kalendar. Sept. the weather will permit; for when they are gathered too early, their fkins will hrivel, fo the fruit will not keep well : and there will be no danger of their fuffering upon the trees until the mornings begin to be frofty, when you muft not let the fruithang longer, efpecially the melting Pears; becaufe if the froft thould pinch their fkins, it would greatly injure them. You muft always obferve to gather your fruit when they and the leaves of the trees are perfestly dry, otherwife it will not keep.

The Grapes of the vineyard, which are now almoft ripe, muft be guarded from birds, otherwife they will make great havock of them where they are fuffered to feed upon them without moleftation; and where the birds have pecked any of the Grapes, the flies and wafps will immediately attack them, and eat them up.

Tranfplant Strawberries, Rafpberries, Goofeberries, and Currants, towards the end of this month, if the weather proves moift, otherwife it will be better to defer it until the beginning of the next month: and this is the beft feafon to plant cuttings of Goofeberries and Currants; which will take root and make better plants, than thofe which are propagated by fuclsers.

Your fruit trees againft the wall of your furcing-frame muft now be pruned and trained 
Sept. The Gardeners Kalendar. $\quad 283$ clofe to the wall or efpalier, that their buds may be preparing before the feafon for applying the heat.

You hould now prepare the ground where fruit trees are defigned to be planted the nexk month, that it may lie to mellow and fweeten; and where new borders are made, the ground will have time to fettle, before the trees are planted; but if the borders were prepared in the former month, the ground fhould be now turned over again, which will prevent the growth of weeds, and be of great fervice in expofing the earth to the air, and hereby the clods will be broken, and rendered fit to receive the trees.

\section{FRUITS in Prime.}

Peaches; the Nivette, Portugal Peach, Bellegarde or Gallande, Roffanna, Pourpree tardive, Purple Alberge, Old Newington, Teton de Venus, Pavy Royal, Admirable, Monftrous Pavy of Pompone, Catherine, Rombouillete, Malacoton.

Plums; White Pear Plum, Bonum Magnum, Green Gage, Reine Claude, Perdrigon, St Catherine, and Imperatrice, Damfons, and Bullace. 
284 The Gardeners Kalendar. Sept.

Pears; Poir du Prince, Autumn Bergamot, Swifs Bergamot, Brute Bonne, Beurre-rouge, Doyenne or St. Michael, Verte-longue, Mouille Bouche d' Automne, Summer Boncretien, Rouffelet de Reins.

Grapes; the Chaffelas, White Mufcadine, Red Murcadine, Black Morillon, Red Morillon, White Morillon, Currant or Corinth Grape, Parlley-leaved Grape, Black, Red, and White Frontignacs, Warner's Red Hamburgh, Black Hamburgh, St. Peter or Hefperian Grape, Orleans, Malnfey, Miller Grape, Damafk Grape, Pearl Grape, Party-coloured Grape, with fome others.

Several forts of Figs, Walnuts, Filberts, Hazle-nuts, Quinces, Medlars, Lazaroles; and, againft north walls, fome Currants and Morella Cherries, upon hot-beds Mielons.

Apples; Embroidered Apple, Pearmain, Golden Rennet, Red Calville. White Calville, Courpendu, Aromatick Pippin, Rennet Grife, Cathead, Quince Apple, Spice Apple, with fome others.

In the bark-bed, the Ananas, or Pine-apple.

Work to be done in the NURSERY.

The middle or latter end of this month, you may plant cuttings of Laurel in Thady borders, obferving 


\section{Sept. The Gardeners Kalendar. $\quad 285$}

obferving to water them frequently in dry weather, which will promote their taking root; for at this feafon there is little danger of their growing, provided they are duly watered.

You may alfo plant cuttings of Honeyfuckles, Goofeberries, Currants, and feveral other hardy trees and Mrubs, which will grow from cuttings; for at this feafon they generally fucceed better than in the fpring.

The ground where you intend to plant out your young ftocks for fruit trees, and other hardy trees and thrubs, thould now be well dug (if it was not done the former month), that the rain may foak into it, and moiften it before the trees are planted.

Toward the end of the month you may begin to tianfplant fome forts of fruit trees, forett trees, hardy Mhrubs, Eंc. obferving to remove thofe firt, whofe leaves are molt de. cayed; but, if the feafon mould prove dry, it will be better to defer it till rain falls; buc if there is a neceffity to remove them, they muit be now and then watered, otherwife their bark will hrink; and thofe trees, which are thus early removed, will pun out new fibres in a fortnight or three weeks time: but thefe teees thould be well fupported with ftakes, otherwife the ftrong winds will blow them out 
286 The Gardeners Kalendar. Sept. of the ground in winter, or difplace them fo much as to injure their young roots; there fhould alfo be fome mulch layed upon the furface of the ground about their roots the beginning of November, before the cold weather fits in, to prevent the froft from penetrating the ground, which would greatly damage thefe new fibres. The trees thus managed will be fo well fettled and rooted before the fucceeding fummer, that dry weather will not injure them near fo much as thofe planted in the fpring; for which reafon moft good nurfery-men choofe to plant out their quarters of ftocks for fruit, foreft trees, and flowering fhrubs, at this feafon; becaufe, where there are la:ge quantities, it would be very expenfive to water them; but, for very moift land, it will be better to defer this planting till fpring, becaufe the wet in winter will often rot the tender fibres of newplanted trees, as fart as they are put out, but efpecially in very moift feafons.

Where Firs, Pines, and other refinous trees are grown fo rude as to require fome of their branches to be cut off, this is the beft feafon for fuch operations; for now they are not fo fubject to weep, as in the fpring; and there will be time for their wounds to heal over before the great rains in winter comes on or hard froft, 
Sept. The Gardeners Katendar. $\quad 287$ froft, both which are hurtful to frefh wounded trees: Walnut trees and Maples hould alfo be trimmed at this feafon, where it is neceffary for the fame reafon.

Work to be done in the FIOW ER-GARDEN.

Dig the borders of your flower-garden, and, if they require it, add fome frem earth, or very rotten dung to them, and plant all forts of hardy flowers therein, obferving to mix them in fuch a manner, that there may be a regular fucceffion of flowers throughout the feafon, in the different parts of the borders in the garden.

Now is the time for tranfplanting biennial and perennial flowers, which were fown and raifed in the flower-nurfery, into the borders of the pleafure-garden, where they are defigned to flower.

The layers of Pinks, Carnations, and SweetWilliams, which have not been tranfplanted from the old roots the former month, fhould be no longer deferred; becaufe, if they are not planted early in September, they will not have time enough to take root before the frofty weather comes on, fo that they will be in danger of fuffering thereby. 


\section{The Gardeners Kalendar. Sept.}

Plant early Tulips in a warm fituation, where they may be defended from cold winds; in which places they will flower in March, or earlier, according as the feafon is more or lefs forward.

The choice Hyacinth roots hould now be planted; in doing of which, after having prepared the beds with good earth (mixed up according to the directions given in the GARDENERS DICTIONARY), about three feet deep, you hould take the earth out of the beds about fix or eight inches deep; then make the bottom level, and draw the lines lengthwife and acrofs the beds, at the diftance which the roots are to be placed, that they may ftand equally in rows; then place the roots upright exactly in the middle of each fquare, and lay the earth on them gently, being careful not to difplace the roots: thefe beds muft be filled up about five inches thick with earth, above the top of the bulbs. This is a much better method of planting thefe roots, than that of making holes for each root with a dibble or other inftrument.

The Box edgings, which are grown too tbick, thould now be taken up and parted, planting it down again according to the directions given in the Gardeners Dictionary; and thofe 


\section{Sept. The Gardeners Kalendar. 289}

edgings which were planted the laft feafon, which have not fucceeded well, may now be repaired.

Prepare the beds for the choice Anemonies, Ranunculufes, and Tulips, the beginning of this month, if it was not done the laft; for the earth thould be allowed fome time to fettle, before the roots are planted; otherwife it will fettle unequally afterwards, when there will be danger of lofing the roots in thofe places where the beds fettle in holes, becaufe the wet will be detained there, which will rot them.

The beginning of the month you hould plant fome of your ordinary double Anemories in warm borders, where they may be fcreened from cold winds; in which places they will flower early in the fpring, provided the feafon proves favourable.

Slip and plant out Polyanthufes, Primrores, London Pride, Thrift, Double Catchfly, Pinks, Peach-leaved Bell-flower, Scarlet Lychnis, Rofe Campion, Daifies, Double Camomile, Double Ragged Robin, Feverfew, and all forts of hardy fibrous-rooted plants, which are propagated by parting their roots; obferving to clofe the earth faft to their roots when you plant them, otherwife the worms will draw them out of the ground. 


\section{The Gardeners Kalendar. Sept.}

Cut down the ftalks of fuch flowers as are decayed, and, where they are not to be tranfplanted, dig the ground about them, and add fome rotten dung, or freth earth, to the borders, which will greatly ftrengthen their roots.

You may yet fow the feeds of Irifes, Tulips, Crown Imperials, Hyacinths, Fritillarias, Colchicums, Cyclamens, Ranunculufes, Anemonies, and moft other bulbous and tuberofe rooted flowers; though it were better if done the middle of the laft month, efpecially if the feafon was moift; otherwife it is as well this month, provided it be done early. Thefe feeds hould be fown in pots or tubs, filled with light frem earth; and the feeds fhould be fown pretty thick, obferving not to cover them too thick with earth, efpecially the $\mathrm{Ra}$ nunculufes and Anomonies, whofe feeds are very thin, and fubject to rot, if buried too deep. Thefe pots or tubs muft be placed to have only the morning fun until the beginning of the next month, when they muft be removed into a warmer fituation. But if the fearon thould prove diry, they thould be refre?hed gently with water.

Sow the feeds of Auriculas and Polyanthufes in pots or boxes of light rich earth, being very careful not to bury the feeds too deep; 


\section{Sept. The Gardeners Kalendar. $29 \mathbf{I}$} deep; which often deftroys them, or at leaft will caufe them to remain in the ground until the fecond fpring, before the plants will come up.

Toward the latter end of the month you may plant your choice Anemonies, Ranunculufes, and Tulips, obferving always to do it in fhowery weather, when the earth is not over dry; for if it fhould continue dry weather any confiderable time after the roots are planted, they will grow mouldy and decay. Thefe roots muft be planted about fix inches afunder, and the Anemonies and Ranunculufes fhould be covered about two or three inches with earth, according as it is light or heavy, over the top of their roots; but the Tulips fhould have at leaft fix inches of earth above their roots, which will caufe them to flower very ftrong.

If the feafon hould prove very wet, you mould thelier your pots of choice Auriculas and Carnations therefrom, or lay the pots down on one fide, that the wet may run off; for great rains, at this feafon, will fill the mould in the pots fo full of moifure, that it will not dry again before winter, whereby the roots of choice flowers will be rotted, or at leaft greatly prejudiced.

$$
\text { U } 2 \text { Toward }
$$


292 The Gardeners Kalendar. Sept.

Toward the end of the month you may tranfplant moft forts of hardy flowering trees and fhrubs, which will fucceed better when they are removed at this feafon, than in the fpring, efpecially upon dry grounds, and will not require fo much watering the following fummer: for they will, at this feafon, take root in a thort time; and fo being well rooted before the drought of the fpring comes on, there will be little danger of their mifcarrying thereby.

This is a proper feafon for parting and tranfplanting ail the forts of Flag-leaved Irifes, Peonies, Aconites, Fraxinellas, Gentianellas, Tuberofe-rooted Geraniums, Afphodel Lilies, Double Meadowfweet, Lily of the Valley, Solomon's Seal, Acanthus, Hardy Apocynums, Columbines, Scarlet Lychnis, Campanulas, Perennial Lathyrus, Digitalis, Perennial Poppy, छc. that they may be well rooted before the fpring, otherwife they will not flower fo ftrong the following fummer. You may alfo part the roots of the early flowering Afters and Golden-rods, whofe ftalks are beginning to wither; and plant them out into large borders, allowing them proper room, otherwife their roots will fpread over whatever plants grow near them. 
Sept. The Gardeners Kalendar. 293

This is the beft feafon for tranfplanting all forts of hardy wood plants and flowers into wilderneis quarters, where they will make a fine appearance the fpring following.

It is alfo the bert feafon to tranfplant Laurels, Lauruftinufes, and Arbutus; for the Laurels now begin to prepare their buds for the next year's hoots, and the other two begin now to produce their flowers: fo that the fooner they are planted, when the rains begin to fall in the autumn, the better they will fucceed.

Plants now in Flower in the PLEASUREGARDEN.

Annual Stock-gifliflowers, Scabioufes, $S_{\text {weet }}$ Sultan, Marvel of Peru, Female Balfamine, China Pinks, Africans, French Marigolds, Hollyhocks, Chryfanthemums, Capficums, Lupines of feveral forts, Sweet-fcented Peas, Tangier Peas, Double Ptarmica or Sneez-wort, True Saffron, Carthamus or Baftard Saffron, A uatumnal Crocufes, Cyclamens, Colchicum, Autumnal Hyacinth, Afters of feveral forts, five or fix forts of Golden-rod, Double Sopewort, Double Camomile, Larkfpurs, Tree Primrofe, Polyanthufes, Spiderwort, Auriculas, Snap-dragon, Venus Looking-glafs, Venus

$$
\text { U } 3 \text { Navẹl }
$$


294 The Gardeners Kalendar. Sept. Navelwort, Candy Tuft, China Starwort, Helianthemums, Heliotropium, Lychnifes, Campanulas, Autumnal Gentians, Scarlet Bean, Oriental Perficaria, Stramoniums, Solanums, Alkekengi with large blue flowers, Santolinas, Chryfocoma, Chelone with white and red flowers, Poliums, Gomphrenas, Xeranthemums, Centaureas, Oriental Mallow, Lavatera, Hefperis two or three forts, Hibicus vefficaria three forts, feveral forts of Sun-flower, Gnaphaliums, Eupatoriums, Heart'seafe, Red Garden Valerian, Catanance quorundam, Ruyschiana, Rudbeckia, Silphium, Large blue Aconite, Wholfome Wolfsbane, Cerinthe, Alyffon fruticofum, Dianthera, Hydrangea, Tetragonotheca, Monarda, Ambrofia, Old Man's Head Pink, Anonis two or three forts, Scrophularias, Dodartia, Echiums, Buglofs of three or four kinds, Convolvulus of feveral forts, Double and single Indian Nafturtium, with fome others.

FHordy Trees and Sbrubs now in Flower.

Jafinine, Monthiy Rofe, Mufk Rofe, Paffron-flower, Arbutus, Pomegranate with double flowers, Shrub Cinquefoil, Mallow tree, Lavatera frutefcens, Hibifcus Syriaca, Larufinus, Honeyfuckle, Scompion Sena, Agnus Caf- 
Sept. The Gardeners Kalendar. 295 tus, Sumach of feveral forts, Celaftrus, Medicago frutefcens, Shrubby St. John's-wort, Itea, Clethra, Kalmia, Azalea, Dwarf Medlar from Crete, Spanifh Broom, Pocock's Bladder Sena, Hamamelis, Symphoricarpos, Ciftufes, Lucca Broom, Cytiffus hirfutus, Tamarifk, with fome others.

Medicinal P L ANTS wobich may now be gatbered for UJe.

Calamus aromaticus, the fruit of the Winter Cherry, Arum or Cuckow-pintle roots, Wholfome Wolfsbane roots, Berberry fruit, Hemp feed, Capficum or Indian Pepper, Baftard Saffron, Cucumber feed, Bitter Vetch feed, Fennel feed, Fenugreek feed, Alifander feed, Walnut fruit, Lettuce feed, Lentil reed, Lovage feed, Gromwell feed, Flax feed, Hops, Millet feed, Sweet Fern feed, Garden Crefs feed, Macedonian Parfley feed, Candy Carrot feed, Common Parfley feed, Raddih feed, Elder berries, Savin, Sefeli feed, Flixweed feed, Muftard feed, Nighthade, Golden-rod.

Work to be done in the GREEN-HOUSE and $\mathrm{S} \mathrm{T} O \mathrm{~V} \mathrm{E}$.

The very tender forts of fucculent plants which were removed out of the ftove in fum- 
296 The Gardeners Kalendar. Sept. mer, muft now be carried in again, efpecially if the feafon proves wet, or the nights cold; for, by the favourablenefs of the weather, thefe plants are fometimes permitted to remain abroad until the end of this month, when, at other times, the weather is often fo bad as to render it neceffary to carry them in at the beginning or middle of the month; for much wet is very prejudicial to them, and fmall morning frofts would deftroy or greatly damage many of them : therefore every one hould be directed by the feafon, when to remove thefe plants into the houfe.

If the bark-beds, in which the Pine apples are plunged, have loft their heat, they fhould be refrefhed, by ftirring the bark up with a fork, and adding fome frefh tan thereto, which will renew the heat; and, if the nights prove cold, the glafies thould be carefully covered, that the plants may be kept in a growing ftate; for it is better to keep them in the bark until the middle or end of October, if the feafon be not too cold, than to place them in the dry ftore too early: becaufe, whenever you remove them into the ftove, there muff be fires made every night, which will dry the earth in the pots fo faft, that they will require to be frequently watered, which is not fo proper for thefe plants at this 


\section{Sept. The Gardeners Kalendar. 297}

feafon: but this is to be underftood of fuch plants only, as are placed in a dry ftove in winter; for thofe plants which are defigned to be plunged into a bark-bed in the ftove, may be removed thither toward the end of the month; at which time the tan muft be renewed with a fufficient quantity of that which is new, that it may retain a warmth through the winter; and thofe plants which are to be planted into the $\tan$ for the next year's fruit, Mhould be now haken out of the pots, and planted as they are defigned to remain, that they may make good roots before winter; for upon this depends their producing large fruit.

Toward the latter end of this month the Orange trees fhould be removed into the greenhoufe, obferving always to do it in a dry day, when the leaves have no moifture upon them; and place them thinly in the houfe, and as near the windows as poffible; for there will be no occafion for placing them as they are to ftand during the winter, until the Myrtles and other hardy plants, are brought into the houfe, which need not be done until the middle or end of October, unlefs the nights Mould prove very cold and frofty; for the longer thefe plants can be kept abroad, the better they will thrive, and be in lefs danger of fuffering in winter; 
298. The Gardeners Kalendar. Sept. but if the Orange trees are kept abroad too long, their leaves will change to a pale yellowin colour; and when this happens, they rarely recover their verdure till the following fummer.

The other kinds of exotick plants, which are to be placed in the ftove, or in glafs-cafes without fires, muft be removed into helter as the fearon grows cold, beginning with the tendereft firft, and fo proceed on to the more hardy kinds; and never place them in exact order until they are all houfed.

The latter end of this month, or the beginning of the next, tan-beds in the ftove fhould be prepared, to receive the tendereft exotick plants, which thould be placed therein, when the bark begins to warm; but care muft be taken not to fuffer the bark to heat violently, for that would injure the roots of the plants, and endanger their health; becaufe, when they receive damage at this feafon, it is almoft impoffible to recover them in winter; therefore if the bark fhould be found too hot, the pots muft not be plunged therein until the heat be abated.

When the exotick plants are placed in the houfe, care hould be taken to pick off all decayed leares from them, and clear their leaves and branches from filth or infects, which, if fermitited to remain upon them, will greatly injure 
Sept. The Gardeners Kalendar. 299 injure them; and the earth in the pots fhould be loofened with a fmall trowel, being careful not to injure the roots of the plants; and where the ftems or branches of the plants have contracted filth, they fhould be well cleaned before they are placed in the ftove.

Plants now in Flower in the GreEn-House, GARDEN, and STOVE.

Oleanders with double and fingle flowers, Colutea Æthiopica, Amomum Plinii, Myrtles, Tree Candy tuft, Scabious tree, Houfeleek tree, feveral forts of Mefembryanthemum, Cotyledons, Aloes, Indian Fig, Double Nafturtium, Spanih Jafmine, Azorian Jafmine, Yellow Indian Jafmine, Arabian Jafmine, Tuberofe, Guernfey Lily, Belladonna Lily, Leonurus, Cytifus incanus, Capers, Granadillas, Senfitive and Humble Plants, Heliotropium arborefcens, Amber tree, Apocynums, Afclepias of feveral forts, Lantanas of feveral forts, Abutilons, Stapelia, Canna Indica, Bean Caper, Indian Arrow-root, African Alcea, African Groundfel tree, Indigo, Palma Chrifi, Spurges, Eun phorbium, Phyfick Nut, Gnaphaliums, Grewia, Papaw, Turnera, Stramoniums, Diofmas, Chironia, Aretotufes, Solanums, Spartiums, Dorias, Lotus Hæmorrhoidalis, Car- 
300 The Gardeners Kalendar. Sept. dinal's flower, Caffias, Sena Alexandrina, Sena Spuria, Hibifcus, Piercea, Pancratiums, Crinum two forts, Hæmanthus with Colchicum leaves, and alfo the broad-leaved fort, Plumeria, Bauhinia, Martynia, Milleria, Ceftrumi, Limodorum, Rauvolfia, Malpighia, Convolvulufes, Baffella, Phyfalis three or four forts, Spigelia, Oldenlandia, Maurocenia, Cliffortia, Lotus with black flow ers, African Wood Sorrel, Ornithogalum luteum, Kleinia, Saururus, Anthericums, Ginger, Coftus, Kempferia, Volkhameria, Galingale, D'ayena, Ruellia, Barleria, Sweet-fcented Heliotrope from Peru, Phylica, Commelina, Rondeletia, Upright Torch Thiftle, Clutia, Geraniums of feveral forts, Arums, Tournefortia, Zinnia, Clitoria, Centaurea, Shrubby Phytolacca, with fome others.

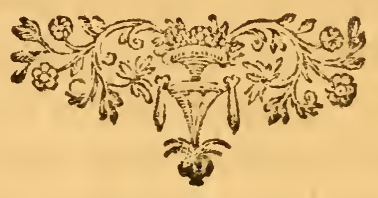




\section{[301 ]}

\section{ce? \\ O C $\mathrm{C}$ T O B E R.}

Work to be done in the KITCHENGARDEN.

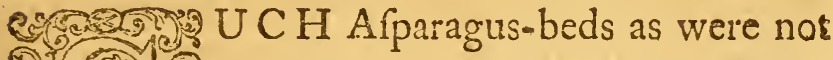
1. 1 dreffed in the former month, 5. 135) 7.2 fould now be done by cutting

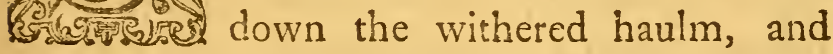
hoeing the weeds from off the beds into the alleys; then dig the alleys, and caft the earth over the beds, burying the weeds in the alleys; but where the beds want manuring, there fhould be fome very rotten dung laid over them after the weeds are cleaned off, and then the earth of the alleys fhould be fpread thereon. When this is finifhed, there may be one row of Cabbage or Colewort plants planted in the middle of each alley, where, in fevere winters, thefe will often efcape, when thofe planted on the level ground are deftroyed; and as they 


\section{The Gardeners Kalendar. Oct.}

will be taken away in March, by the time the Afparagus-beds are dreffed in the fpring, they will not injure it in the leaft.

In dry weather continue to earth up Celery and Cardoons to blanch them; and draw up fome Endive, which is full grown, to plant down on the fides of the ridges to whiten; becaufe the cold, at this feafon increafing, will injure it where it remains above ground tied up to blanch, as was directed in the former month, efpecially if it prove frofty; but in mild feafons the Endive, which is tied up, will continue good till the end of next month.

Tranfplant brown Dutch, and common Cabbage Lettuces, upon warm borders, near walls, pales, or hedges, to abide the winter; as you may alfo fome Cos, Cilicia, and Imperial Lettuces; but it will be proper to plant fome of all thefe forts upon beds, to be covered with frames or mats in winter; becaufe, if the froft thould be very fevere, it will deftroy the Cos and Cilicia Lettuces, where they are expofed to the open air. But thore plants which are put under frames, Thould be fmaller than thofe planted in open borders; becaufe the large plants, when covered, will be apt to be too forward in mild winters. 


\section{Oct. The Gardeners Kalendar. 303}

The Spinach, Carrots, Onions, $8 \mathrm{c}$. which were fown the end of July, or in Augurt, mult now be kept clean from weeds; for if they are permitted to grow, they will over-run and fpoil the crops, efpecially the Spinach, which will rot off wherever the weeds fpread over it.

Plant Beans, and fow Peas, upon dry grounds, and in warm fituations, which fhould be repeated twice; the firft at the beginning, and the other at the end of this month; becaufe if the firft thould be too forward to ftand the winter, the other, being put into the ground later, may fucceed.

Toward the end of this month, tranfplant the Cauliflower plants into the places where they are to abide the winter; fome of which Thould be put under bell or hand-glafies, if you have any, obferving to plant two plants under each glafs, becaufe if one of them thould fail, the other will be fufficient: for in the fpring, if they both live through the winter, one plant mult be tranfplanted out. Thefe plants which are put under glafes, will come earlier than thofe which are wintered in beds, and tranfplanted out in the fpring, by a fortnight, or more. You may aifo plant fome of thefe plants on warm borders, near walls, pales, or hedges; where, if the winter doth not prove 
304. The Gardeners Kalendar. Oct. very fevere, they will ftand very well. But thofe plants which are for the general crop, fhould be planted under frames to fecure them again?t hard froft.

The Cabbage plants, which were fown in the beginning of Auguit, thould now be tranfplanted out for gond (efpecially thofe of the early kind); but it will be proper to have fome plants in a warm frituation referved, left the froft inould deftroy thofe which are planted out in the full ground; or if any of thefe now planted out, run up to feed in the fpring, which is frequently the cafe in mild feafons, or when the feed is fown too early, there may be a fupply of plants to make them good. As to the Long-fided Cabbage, which is a later fort, that need not be planted out for good till $\mathrm{Fe}$ bruary.

Where any beds of Welih or common Onions were fown, they thould be cleaned from weeds; for at this feafon the blades of the Welh Onions will intirely decay, fo that before the culture of them was fully known, many perfons have fuppofed the Onions were dead and dug up the beds; but in fix weeks or two months after, they will come up again very ftrong, and refift the fevereft froft ; fo that when all the common fort of Onion is deftroyed 
Oct. The Gardeners Kalendar. 305 by the cold, thefe will remain; which was the occafion for their being fo much cultivated in gardens near London, fome years fince; but their ftrong flavour renders them lefs efteemed than the other fort, fo that of late years they have not been fo generally propagated.

You muft now fow all forts of fallet herbs upon moderate hot-beds, either under frames, or arched over with hoops, where they may be covered with mats or cloths, to protect them from froft; otherwife they will be in danger of being deftroyed thereby, as foon as they ap-pear above ground: but where there are many. bell or hand-glaffes, the feeds may be fown under them, notwithftanding the two Cauliflower plants which are there planted; for if the feeds are not fown too near the ftems of the plants, or the falletting be not fuffered to remain toa long about them, it will not injure them; this being conftantly practifed by the gardeners near London, with good fuccefs.

Some of the Colewort plants, which were late fown, fhould now be planted out where they are to remain for fpring ufe, that they may fucceed thofe which were planted out the former month.

The Cauliflowers which were fown in May, will now begin to thew their heads: therefore 
306 The Gardeners Kalendar. Oct. they muft be diligently looked over two or three times a week, to break down fome of the inner leaves upon them, which will protect them from the froft or wet, both which, as alfo their being expofed to the fun, will change their colour, and caufe them to be unfightly.

The ftems of Broccoli plants fhould be earthed up, to protect them from froft; but you munt be careful, that the earth be not drawn into the hearts of the plants, for that will fpoil their heads, if not deftroy them.

Toward the end of this month fome of the leaves of the Artichoke hould be cut clofe to the furface of the earth, and the ground between them fhould be trenched, obferving to lay a good ridge of earth over each row of plants, to protect them from froft ; but by no means lay any new dung about them, as is by fome unfkilful perfons too often practifed, which renders the plants hard and woody in the fpring, and caufes them to produce fmall and ilk-nourithed heads; but where the ground wants amendment, there fhould be fome very rotten dung buried between the rows, when the ground is trenched, which will greatly ftrengthen the plants. But if the feafon is likely to continue mild, this work had better be deferred a month later. 


\section{Oct. The Gardeners rislendar. $3 \odot 7$}

You may now fow forne Radines upon warm borders, to come early in the fpring; and if fome Carrot feed is mixed with the Radifh feed, if the Radifhes thould be dentroyed, the Carrots may ftand, and come early in the fpring.

Make fome moderate hot-beds to plant Mint and Tanfey upon, that both forts may be fit for ufe by Chriftmas, when they are often required at the table; and thefe beds will continue to produce, until thofe in the open air come in, provided they are fecured from froft.

Make hot-beds for Afparagus, when it is required to have it at table in December; but where it is not wanted fo early, it is better to ftay until December or January, before the beds are made, for the Afparagus will not be near fo large, nor well coloured, which is produced in the middle of winter, when there is little fun, as thofe which come in February, and after: but in fome families Afparagus is required all the winter; therefore there muft be one bed, at leaft, made in this month.

The Muthroom-beds mutt be now carefully guarded from wet and froft, either with frames and glaffes, or with thatch; for if the wet roaks into the beds, it will deftroy them. If this be 


\section{The Gardeners Kalendar. Oct.}

carefully obferved, a crop of Mulhrooms may be continued all the winter.

At this time the dung of thofe Melon and Cucumber-beds which were made the laft fpring, fhould be laid on the quarters of the Kitchen-garden, as fhould alfo the dung of the lay-ftall, that it may be fpread on the furface, ready to be dug into the ground, when the quarters are trenched.

Cut down the decayed ftalks of Mint, Tarragon, Baum, and other perennial rooted plants, whofe ftalks are annual : the beds thould alfo be cleaned from weeds, and if a little rotten dung is fpread over the beds, it will greatly amend them : the alleys alfo hould now be dug, and the whole made clean.

Where there are beds of feedling Afparagus plants, which are intended for tranfplanting the fucceeding fpring, there fhould be fome very rotten dung fpread over them, toward the end of the month, when the haulm is decayed; this will prevent the froft from injuring the buds, if the winter hould prove fevere, and be of great ufe to the plants.

Where there are Reed fences in the Kitchengarden, they fhould now be tied anew with Ofiers, to prevent their being blown down by 


\section{Oct. The Gardeners Kalendar. 309}

the frong winds which ufually happen at this feafon, or foon after.

\section{Products of the KITCHEN-GARDEN.}

Cabbages, Savoys, Cauliflowers, fome Artichokes, Carrots, Parfneps, Turneps, Onions, Leeks, Potatoes, Rocambole, Shallots, Beets, Skirrets, Scorzonera, Salfafy, Turnep-rooted and Black Spanith Radihes, and fometimes the common fort in mild feafons are now plenty; Celery, Endive, Cardoons, Finnochiz Chervil, Corn faller, Rape, Radih, Muftard, Creffes, Lettuce, Parfley roots, Chard Beet, Cauliflower Broccoli, and all forts of young Sallet herbs; and on warm horders fome Cabbage Lettuce, Spinach, Coleworts, Borecole, Turnep-rooted Cabbage, Sorrel, Marigolds, Mußhrooms, Sprouts, with Sage, Rofemary, Thyme, Winter Savory, Pot Marjoram, and many other aromatick plants.

\section{Work to be done in the FRUIT-GARDEN.}

The middle or latter end of this month is a good time for to prune Peach trees, Nectarines, Apricots, and Vines; which is much better than to fay until the fpring, as is the common practice; 


\section{The Gardeners Kalendar. Oct.}

practice; for if this work be performed early in autumn, the wounds will heal over before any hard froft comes on to injure the fhoots, fo will be in no danger of injury therefrom; and by cutting off all the ufelefs branches at this feafon, and thortening thofe which are left, the trees will be the ftronger, and the bloffom buds will be better nourined; for when the fhoots are left to their full length till fpring, the buds upon the upper part of the branches will be larger, and more turgid, than thofe upon the lower part: the fap flowing more plentifully towards the ends of the hoots, whereby the buds below upon thofe parts of the fhoots, which are defigned to be left for bearing, are thereby rendered weaker : befides by pruning at this feafon, the borders may be dug and made clean before winter; whereby there will be lefs bufinefs to do in the fpring, when the ground is to be cropt ; fo that the fooner this work is done, when the leaves begin to fall, the better.

You may alfo prune Pears, Apples, and Plums, which work may be continued until the latter end of the next month, according as the feafon proves favourable; but this work thould never be performed in hard frofty weather, becaufe then the fhoots which are weak, are fubject to perim at thofe places where they are cut. 
Oct. The Gardeners Kalendar. 3 I I

This month the Grapes in the vineyard fhould be gathered, which thould always be done in dry weather, when there is no moifture on the Vines; you fhould alfo be careful not to put any unripe or decayed Grapes among the good ones, for thofe will fpoil the wine.

Thofe Grapes which are defigned to be preferved for the table in winter, after thofe upon the Vines are gone, fhould now be cat, with a joint of the Vine to each bunch, and hung up in rows, fo as not to touch each other, in a warm room, where fires are pretty conftantly kept in winter, in which places they will keep till February.

If the foil of the garden is dry, this is the beft feafon for tranfolanting all forts of fruit trees; and if the trees are to be purchafed from Nurfery-gardens, you may have much greater choice of plants now, than in the fpring, when the Nurferies are generally cleared of the beft trees: in the choice of them, take fuch as are upon young flocks, which have not been headed down, and whofe grafts or buds are of one year's growth; nor fhould thofe trees which are defigned for walls or efpaliers be cut down until the fpring; their roots only thould be pruned, and all the fmall fibres entirely cut off;

$$
\text { X } 4
$$




\section{I 2 The Gardeners Kalendar. Oet.}

for if thefe are left on, they foon grow mouldy and perin, frequently injuring the new fibres which are fent out from the roots. After the trees are planted, their branches fhould be faftened to the wall, pale, efpalier, or ftakes, to prevent their being loofened by the winds; and fome muich thould be laid upon the furface of the ground about their roots before winter, to prevent the froft from penetrating to them; but this mulch need not be laid about the trees, until there is danger of hard froft ; becaufe, where the mulch is laid about them early, and pretty thick, it will keep out the autumnal rains, and thereby do more hurt than good.

Plant Goofeberries, Currants, Rafpberries, and Strawberries, that they may take root before winter; for many of thofe which are planted at this feafon, will produce fruit the following fummer; whereas when they are planted in the fpring, they have feldom ftrength enough to p:oduce any (or at leaft very few) untii the fecond year.

You may now tranfplant ftocks of all kinds of fruit . into the Nurfery, to graft or bud the moft generous kinds of fruit upon; in doing of which, if you obferve to mulch the ground about their roots before winter to keep. 
Oct. The Gardeners Kalendar. $3 \mathbf{I} 3$ the froft out, it will be of great fervice to them.

The old beds of Strawberries thould now be dreffed; in doing of which, they thould be cleaned of weeds, and the firings or runners taken off clofe to the ftems of the plants; then the alleys thould be dug, and after breaking the earth fine, it fhould be fpread over the beds between the plants, being careful not to bury them. The rows of Rafpberries thould alfo be planted, and thofe intended to remain thould be pruned, cutting out the old wood, and the ground between the rows fhould be dug, which will make the place neat, and greatly encourage the plants.

The Currant buhes may now be pruned, and their branches may be tied up with a withy, and the ground between them dug, which may be planted with Coleworts or Cabbage plants, to remain till ipring, in which place they will fometimes abide the winter, when they are deftroyed in more open fituaations; for the Currant buhes will prevent the froft from penetrating fo deep into the ground, as it will where the ground is entirely clear: you may alfo prune Goofeberry bufhes, and dig up the ground between them; and, where there is room, you may plant fome of the like forts of plants, which will be taken off the ground 

ground in the fpring, before the buhes put out their leaves, and by digging of the ground, the fruit of both forts will be greatly improved.

Preferve the ftones or kernels of fuch forts of fruit as you intend to fow for to propagate for ftocks, in fand, until the feafon for fowing them; but you mult place them out of the way of mice and rats, which will deftroy them if they get to them; and, whenever you put any of them into the ground, the fame caution muf be obferved; for thefe vermin will foon deftroy your kernels, where they can come to them, if they are not prevented.

You hould now gather all forts of winter fruit; but this fhould always be done when the trees are perfectly dry, otherwife the fruit will not keep fo well. Your choice forts of winter Pears fhould be laid in an heap in a dry place, for about a fortnight or three weeks, to fweat; after which time they thould be carefully wiped dry, and each fort put up into a feparate bafket, with paper put round the fide and the bottom of each, as alfo over the fruit, to exclude the external air; in which method they will keep much better than where they are fpread thin on thelves, and expofed to the air, whereby their fkins will become flaccid; and if fome of the moft choice forts are each wrapped in 


\section{Oct. The Gardeners Kalendar. 3 I 5}

white paper, it will prevent their touching each other, and preferve them longer.

\section{FRUITs in Prime:}

There is yet the Bloody, Malacoton, Old Newington, Double Swalm, and fome Catherine Peaches, Grapes, late Figs, Medlars, Services, Quinces, Black and White Bullace, Imperatrice Plum, with Walnuts, Hazle-nuts, and Almonds.

Pears; the Doyenne or St. Michael, Beurrerouge, Swifs Bergamot, Verte-longue, Longftalked Mufcat, Monfieur Jean, Rouffeline, Green Sugar, Befidery, Marquis, Mufcat Fleury, Befi de la Mote, Chat-Brulé, Swan's Egg, Crafan, St. Germain, Beffy Chaumentelle, and Autumn Boncretien from a warm wall, with others of lefs note.

Apples; Golden Rennet, Golden Pippin, Loan's Pearmain, Quince Apple, Red Rennet, Autumn Pearmain, Red Calville, White Calville, Rennet Grife, Royal Rufiet, Embroidered Apple, with fome others.

Work to be done in the NURSERY.

The beginning of this month continue to trench the ground for planting out young ftocks, 


\section{$3^{\text {I } 6}$ The Gardeners Kalendar. Oct.}

ftocks, to ingraft and bud the feveral forts of fruits upon; as alfo to plant out flowering fhrubs, and other wildernefs trees. And about the midd $e$ of the month you may begin tranfplanting of them into quarters, placing them in rows, allowing them a proper diftance, according to their feveral growths.

This month is the mont proper feafon for tranfplanting moft forts of hardy trees, efpecially in dry foils; for at this time they will foon purh out new roots, whereby they will be eftablined before the drought of the fucceeding fummer, fo will be in much lefs danger of fuffering than thofe tranfplanted in the fpring. But you mut be careful to ftake all ftandard trees; and thofe planted againft walls, pales, or efpaliers, thould be faftened thereto, otherwife the wind will turn them afide and difplace them, by which the tender fibres, which are newly puthed out from their roots will fuffer much, to the great injury of the trees.

In dry weather carry dung into fuch parts of the Nurfery where it is wanted, and fpread it upon the furface of the ground round the ftems of young trees; this will keep the froft out of the ground, and the rains of winter will wafh in the falts to the roots of the trees; and in the 
Oct. The Gardeners Kalendar. $3 \mathbf{I} 7$ fpring, when the ground is dug between the trees, the dung may be buried.

You may now put into beds the ftones of Muffel Plums for ftocks, obferving to cover them an inch thick with light earth; and then lay fome light mulch over the furface of the bed, to keep out the froft, and prevent the mice from getting to them.

This is the proper feafon to fow Acorns, which will fprout if they are kept long out of the ground, and are thereby fpoiled. You may alfo fow Beech-maft as foon as it is ripe, for this will not keep good long out of the ground. Hawthorns of all forts, Yewberries, and Hips of Rofes, hould now be fown, obferving to cover the beds, as was directed for the Muffel Plums: thefe feeds, fown at this feafon, will often come up the fucceeding fpring; whereas thofe fown in the fpring, if they do grow, will not come up until the fpring following; but many people dig a trench in the ground about a foot deep, and lay the Haws, Hips, and Hollyberries therein, covering them over with earth pretty thick, letting them remain one year; then they take them out, and fow them in beds the following October, and the plants will come up the fpring after.

This 


\section{The Gardeners Kalendar.}

This is alfo the beft feafon for fowing all the forts of Maple feed; for thofe which are kept out of the ground till fpring, rarely grow, or at leaft not until the year after.

Prune all forts of foreft trees and flowering Mrubs ; in doing of which, all rude branches fhould be cut off clofe to the ftems, and not leave fpurs, as is too often practifed, which will render them very unfightly; there hould alfo be care taken to leave a fufficient quantity of branches on the ftems of young ftandard trees, to detain the fap for the augmentation of their trunks, otherwife they will not be ftrong enough to fupport their heads.

Now is the beft time to make layers of Elms, Limes, and all other hardy trees and Thrubs which thed their leaves in winter; the doing of which at this feafon, will greatly promote their taking root; for the moifture in winter will fetthe the ground about them, and prepare them for pufhing out roots early in the fpring.

Take off the layers of Elms, Limes, and other foreft trees, or flowering Ahrubs, which were laid down the former year; then prune their roots, and plant them in rows in the Nurfery. You may now plant out fuckers of Lilacs, Rofes, and fuch other flowering trees and Ibrubs, which are propagated this way, into the

Nurfery, 
Oct. The Gardeners Kalendar. 319

Nurfery, where they may remain two years, to get ftrength before they are placed where they are to remain.

Plant cuttings of the feveral forts of Honeyfuckles, Laurels, Portugal Laurel, and other hardy trees and hrubs: thefe hould be planted in a loamy foil, where they will fucceed much better than in a light, rich, or fandy ground.

This month is a proper feafon for planting the cuttings of Plane trees, Poplar trees, and Alders: thefe fhould be planted in a moift ground but not in very wet foils; and, in making the cuttings, a knot of the former year's wood hould be preferved at the bottom of each. When this is obferved, few of thefe cuttings will fail.

The beft forts of Goofeberries and Currants may now be propagated from cuttings, which, if properly chofen, and carefully planted at this feafon, will make good plants in one year, and the plants fo raifed are much preferable to luckers.

Lay down the fhoots of Lauruftinus and Phillyrea this month : the former of thefe will be rooted well in one year, but the latter fhould remain two years before they are diffurbed. 


\section{The Gardeners Kalendar. Oct.}

Work to be done in the F L OW ER-GAR DEN.

The middle or latter end of this month finih planting all the forts of flower roots, which are defigned to be put into the ground before Chriftmas ; as Tulips, Anemonies, Ranunculufes, Crocufes, Jonquils, Hyacinths, Narciffufes, Bulbous Irifes, Martagons, Orange Lily, and all fuch as have been kept above ground fince their leaves decayed in fummer; for if any of thefe roots are fuffered to remain in the ground a few weeks after their leaves are decayed, they will puft out frefh fibres, when it will be too late to take them up. Nor fhould thefe roots remain long out of the ground; for if fome of the forts are kept long out of the ground, they will decay: fo that fuch bulbous rooted flowers as were not taken up at the proper feafon, fhould not be now difturbed, left thereby they fhould be deftroyed; or, if they do live, they will be fo much weakened, as to prevent their flowering the following fummer; and fometimes they are two or three years before they recover.

Tranfplant into the borders of the flowergarden moft forts of hardy tuberofe rooted or fibrous rooted plants; fuch as Hollyhocks, 
Oct. The Gardeners Kalendar. $32 \pi$

Canterbury-bells, French Honeyfuckles, Columbines, Monks-hoods, Daifies, Chryfanthemums, Polyanthufes, Sweet Williams, London Pride, Campanulas, Afters, Golden-rods, Spiderwort, Afphodel or Kingfpear, Pionies, Wall flowers, Thalictrums, Eryngiums, Thrift, Perennial Sun flowers, Great Bluebottle, Tuberofe-rooted Irifes, Centaureas, Double Feverfew, Double Camomile, Doronicum, Cirfiums, Caffida or Skullcap, Everlafting Pea, Perennial Aftragalufs, Hardy Apocynums, Perennial Poppy, Yellow and Tangier Fumitaries, Bean Caper, Foxgloves, Horned Poppy, Perennial Navelwort, feveral forts of Phlox, Alyffum of Crete, Tree Primrofe, Rudbeckia or Dwarf Sun flower, Perennial Geraniums, St. Peter's-wort, Violets, Honefty or Satten flower, Globe Ranunculus, Lyfimachias, Dwarf Ciftufes, Double and fingle Rofe Campion, Ragged Robin, Monarda of three forts, Ruyfchiana, Double'Pilewort, with many other forts, obferving to intermix them in fuch a manner, that there may be a fucceffion of flowers preferved throughout the feafon.

Clean all the borders of the flower-garden from weeds; and thofe which were not dug the former month, thould be no longer deferred; obferving to renew them with frefh earth, or fome very rotten dung, in the manner directed 
in the former month. You may alfo continue to plant Box-edgings to borders where they are wanted, and repair thore which are decayed: this may be done any time before the froft fets in fo as to freeze the ground.

Thofe borders which were dug and planted the beginning of Sepiember, fhould now be raked over again, which if properly done in dry weather, will deftroy all young weeds which may have come up fince, and make the borders clean and handfome all the winter feafon.

The beds of feedling Hyacinths, Tulips, Fritillaria, and other bulbous rooted flowers, which have remained in the ground all the year, mut now be carefully cleared from weeds, and have frem rich earth fifted over the beds, half an inch thick, which will preferve the roots from froft, and greatly ftrengthen them.

The pots and boxes of feedling flowers fhould now be removed out of their hady fituation, where they have remained during the heat of fummer and autumn, and placed in a warmer pofition, where they may enjoy as much of the benefit of the fun as poffible, and be fcreened from cold winds: they thould alfo be cleaned from weeds. In doing of this, there 
Oct. The Gardeners Kalendar.

muft be great care taken not to draw the bulbs out of the ground: for as thefe roots are very fmall, fo they are eafily drawn out with the roots of the weeds, efpecially if the weeds are large, or have taken deep root ; and after this is done, they hould have a little frefh earth fifted over them: but this muft not be laid too thick, left the roots fhould be buried fo deep as to rot in the ground.

The end of this month the pots of choice Carnations fhould be placed under cover, where they may be defended from violent rains, fnow, and fevere froft, all which are enemies to thefe flowers: therefore, if they are planted in fmall halfpenny pots, as was directed in the month of Auguft, they may be placed very clofe together, in a garden frame, or upon a bed arched over with hoops, that they may be covered with mats in bad wearher; but in mild dry weather they cannot have too much air; or if thefe pors are plunged either into the ground, or in rotten tan up to their rims, to prevent the froft from penetrating quite through them to the roots of the plants, it will be a more fecure method.

The pots of choice Auriculas thould have their decayed leaves taken off, and the pots muft be laid on one fide, or placed under cover, to prevent their receiving too much wet, 


\section{The Gardeners Kalendar. Od.}

which will be apt to rot them; though they will endure cold very well.

Tranfplant moft forts of flowering thrubs and trees; as Rofes, Honeyfuckles, Spanifh Broom, Cytifus, Laburnums, Althæa frutex, Spiræas, Gelder Rofe, Lilacs, Scorpion Sena, Bladder Sena, Virgins Bower, Double flowering Peach, Almonds, Double flowering Cherry, Bird Cherry, Robinia, Scarlet Horfe Cheftnut, Scarlet flowering Maple, Syringa, Jafmines, Catalpa, Mezereons, Upright Honeyfuckle, Trumpet Honeyfuckle, Flowering Rafpberry, Double Bramble, Cockfpur Hawthorn, Double Hawthorn, Shrub Cinquefoil, Cornelian Cherry, Quick-beam, Privet, Cherry Plum, Sumach, Coccygria, Sea Buckthorn, Bladder-nut, Arbutus, Lauruftinus, Glaftonbury thorn, feveral forts of Sumach, Tamarifks, Ec. which, if planted at this feafon, will take root before winter, whereby they will be in lefs danger of fuffering from drought the following fpring, and moft of them will flower the next fummer; whereas thofe which are removed in the fpring will require to be conftantly watered in dry weather, and rarely flower the fame year : but fuch of thefe fhrubs which are not hardy and are planted at this feafon, mult have fome mulch laid upon the fur- 


\section{Oct. The Gardeners Kalendar. 325}

face of the ground about their ftems in winter, to prevent the froft from penetrating the earth to their roots: but this hould not be done till the frof comes on; before which time the mulch will do more harm than good, by preventing the rain from entering the ground to their roots.

Clean the walks and lawns near your wilderneffes, of the leaves which have fallen from the trees; for if they are fuffered to rot upon the grafs, they will greatly injure it; and if they remain upon gravel walks to rot, they will difcolour the gravel, and render it unfightly: and where there are large gravel walks, which are feldom ufed in winter, they may now be trenchea up, and layed in ridges, which will prevent weeds and mofs from growing thereon during that feafon, and preferve the gravel fre?h. But this is only to be practifed where the walks are not ufed during the winter feafon, or where there is not fufficient help allowed to roll them conftantly.

Prune all forts of flowering fhrubs; as Rofes, Honeyfuckles, Spiræas, $\Xi^{2} c$. taking off all fuckers which come from their roots, which, if fuffered to remain, will ftarve the old plants, and prevent their flowering; the Lilac, in particular, which fends forth great numbers of fuckers 
326 The Gardeners Kalendar. Oct. from their roots, if they are not annually taken off, will fpread over the ground to a great diftance, and make a thicket; but will not flower near fo well, as when the trees are kept clear and fingle. Thefe fuckers, if wanted, may be planted in the nurfery; where, in two or three years time, they will get ftrength enough to be tranfplanted where they are to remain.

Where there is any ground which is defigned to be laid out for pleafure, either in a flower-garden or wildernefs, which cannot be got ready for planting before the fpring, there fhould be no time loft at this feafon, in preparing of it, that it may be expofed to the froft in winter, which will mellow it; befides, if the froft hould continue long, it may prevent working till the feafon is too far fpent for planting in the fpring, whereby a whole feafon will be loft.

The beginning of this month plant fome cuttings of the Double Chryfanthemums, both white and yellow, in pots filled with good earth, and place them in a fhady fituation, obferving to water them frequently, if the feafon proves dry. Thefe cuttings will foon take root; and, if they are placed under a common frame, where they may be protected from froft in winter, and have as much free air as poffible in mild wea-

ther, 


\section{Oct. The Gardeners Kalendar. 327}

ther, the plants will be ftrong cnough, by the fpring, to plant in the borders of the flowergarden; and by this method they will all have double flowers, and no fingle ones among them, but the plants fo propagated, will foon become barren and produce no feeds.

In this month you fhould put the bulbous roots of Tulips, Hyacinths, Jonquils, Narciffufes, $\Xi^{2} c$. upon glafies filled with water, for to flower in rooms early in the fpring: thefe glaffes hould be placed where they may have as much free air as poffible, while the weather continues mild; for if they are kept in clore rooms, their leaves and ftalks will be drawn up fo weak, that their flower-ftalks will not be able to fupport the flower as they fhould do; therefore they fhould not be fet into the rooms, until the flowers are almoft ready to open: nor hould they be expofed to bad weather after they begin to put out their leaves; fo that if they are placed near the windows of a Greenhoufe where they may have free air in mild weather, and be fcreened from cold, they will produce much ftronger flowers. The glaffes for this purpofe, are now well contrived, and fo generally known, as to render their defcripkion here unneceflary. 


\section{The Gardeners Kalendar. Oct.}

Plants now in Flower in the $\mathrm{PL}$ E A S U REG A R D EN.

Several forts of Starworts (and in open mild feafons there ftill continues Africans, French Marigolds, Marvel of Peru, Balfamine, Sweetfmelling Refeda, Amaranthus. Tricolor and Cockfomb, Gomphrena with white and purple fiowers, Palma Chrifti, Diamond Ficoides, and fome other tender annual plants), feveral forts of Golden-Rod, Autumnal Crocufes, YelJow Autumnal Amaryllis, Cyclamens, Colchicums, China Pinks, Sweet Sultans, Polyanthufes, Auriculas, Three coloured Violets or Heart's Eafe, China Starwort of three colours, Oriental Perficaria, Chryfanthemum Creticum, Linaria, Stock-gilliflowers, Phyfalis, Buphthalmum, Tuberofes, Guernfey Lily, Belladonna Lily, Rudbeckia or Dwarf Sun flower, Heliotropium, Oriental Buglofs, American Dogfbane of feveral forts, Alclepias of three or four forts, Snapdrazon, Saffron, Baftard Saffron, Double Feverfew, Convolvuluíes of feveral forts, 8 weet-fcented Peas, Lupines, Venus Lookingglafs, Venus Navelwort, Doube Thorn apple, Centauea of feveral forts, Hawk-weeds, fome ingle Anemonies, Sun towers, Indian Scabious, 


\section{Oct. The Gardeners Kalendar. 329}

Broad-leaved Phlox, Trachelium, Dianthera, Eupatoriums, Alyffon fruticofum, Dracocephalum of feveral forts, Oriental Sage, Helenia, Honeywort, Autumnal Gentian, Old Man's Head Pink, feveral forts of Lychnis, Double Sopewort, Tradefcant's Spidewort, Commelina, Chelone, fome forts of Scrophularia, Tobacco, Aconite with large blue flowers, wholfome Wolfsbane, Campanula patula, with fome others.

\section{Hardy Trees and Sbrubs now in Flower.}

Arbutus, or the Strawberry tree, Late flowering Honeyfuckle, Evergreen Honeyfuckle, Althæa frutex, Paffion flower, Cytifus, Lunatus, Ketmia Syriaca, Lauruftinufes, Monthly Rofe, Murk Rofe, Shrub Cinquefoil, Flowering Rafpberry, Male Ciftus, Phlomis, Hamamelis, Double Pomegranate, Scorpion Sena, Agnus Cåtus, Pyracantha in fruit, Euonymus or Spindle tree in fruit, Groundfel tree, feveral forts of Sumach, Tamarifk, Ealtern Bladder Sena, Bignonia or Trumpet flower, Hydrangea, Itea, Clethra, Spanifh Broom, Luca Broom, Red Spriæa, White American Spiræa, Galeopfis frutefcens, American trailing Arbutus, Shrubby St. John's-wort, with fome others. 
$33^{\circ}$ The Gardeners Kalendar. Oat.

Medicinal Plants worich may now be gatbered for UJe.

Calamus Aromaticus Roots, Winter Cherry, Wholfome Wolfsbane root, Arum roots, Afarabacca roots, Berberry fruit, Saffron, Beet rcot, Eringo root, Ah-tree feed, Henbane root and feed, Juniper-berries, Lovage feed, Valerian root, Savin, Sopewort root, Sea Lavender root, Scorzonera root, Skirret root.

Work to be done in the GREEN-HOUSE, and $\mathrm{S} T O \mathrm{VE}$.

The beginning of this month, if it was not done in the former, you hould remove your Orange trees into the green-houfe, obferving, as hath been already directed, to do it in a dry day; as alfo to clean their heads and ftems before they are houfed, and fir the earth on the top of the tubs or pots, adding a little very rotten neat's dung thereto; which will refresh the trees, and prevent mofs from growing in the tubs or pots.

You mut now alfo carry into the confervatory your tender Geraniums, Double Indian Nafturtium, Spanilh Jafmines, Azorian Jarmines, Yellow Indian Jafmines, Mefembryan- 
Oct. The Gardeners Kalendar. $33 \mathbf{I}$ themi, Sedums, Cotyledons, Amber tree, Sorrel tree, Malabar Nut, Leonurus, Hermannias, Diofma, Celaftrus Africanus, Phylica, Lotus Sancti Jacobi, ftriped and fpotted Aloes, Kleinias, Arctotufes, Canary Campanula, Siryrinchiums, Elichryfums, Clutia, Arbo: Molle, Chironia, Lyciums, Watfonia, Ixia, African Wood Scrrel, Gladiolus Indicus, Indian flowering Reed, Lentifcus, Solanums, Phyfalis frutefcens, Perfian Cyclamen, African King's Spear, with many other forts, which are hardy enough to remain abroad until morning frofts begin to come on, when they hould be removed into thelter; but thefe muft have as much free air as pcfible, when they are in the houfe during the continuance of mild days; for if they are too clofe fhut up, when they are firft houfed, they will take damp, and their leaves will fometimes decay, and fall off; they muft alfo be frequently refrefhed with water, and the decayed leaves conftantly picked off.

If the tan-beds in the ftove are not already renewed, it muft now be no longer deferred; for the cold increafing, will check the tender exoticks, if they are not placed into new beds; in doing of which, there muft be care taken not to plunge the pots into the bark until it begins to warm; nor hould they be put deep 


\section{The Gardeners Kalendar. Oct.}

into the bark, if it be too hot, in which cafe it will be fafer to plunge them but a fmall depth at firt, until the violent heat is abated; for if the roots of the plants are fcorched with the heat, they rarely recover again. You muft alfo obferve to wafh the leaves and ftems of fuch plants as have contracted any filth, or that are infefted with infects; otherwife the infects will fpread themfelves over all the plants which are placed near them, and be very injurious to them.

Toward the latter end of the month it will be proper to take into fhelter the Myrtles, Oleanders, Cytifures, Dorias, Gum Ciftus, Common Aloe, Candytuft tree, Ofteofpermum, $\mathrm{Pe}$ rennial Bupthalmum, Wormwood tree, Royenias, Olives, Tetragonias, Large Magnolia, Indian Bay, African Tanfey, Heliotropiums, Cliffortia, Wackendorfia, Shrubby After, and other hardy exotick'plants; at which time all the plants in the green-houfe mould be placed in the order they are to remain during the winter, obferving where there is room to place them in fuch a manner, that the branches of the plants may not interfere with each other, but that their heads may ftand fingle, and the air freely pars between them. 


\section{Oct. The Gardeners Kalendar. 333}

The Ananas or Pine-apples, which are to fruit the next feafon, muft now be placed in the bark-bed in the ftove, where they are defigned to remain to ripen their fruit, that they may enjoy a proper degree of heat; and during the winter, the plants hould be refrerhed frequently with water, which, in hard frofts, fhould be placed in the ftove twenty-four hours before it be ufed, but not too near the fireplace or flues, left it is made too warm, but - nly to acquire a proportionable warmth with the air of the houfe; for if the roots of the plants thould have their fibres much dried in winter, the plants will receive fo great injury as to render the fruit fmall; and by this negleet alfo many times the young plants, raifed from the laft year's crowns and offsets are brought to fruit, which were not defigned for fruiting until the following year; and fo, confequently, their fruit will be very fmall, and of little value: but, on the other hand, there muft be great care taken, not to give them too much water, nor to repeat it too often; for much wet, at this feafon, will be equally injurious to them.

The beginning of this month, if the feafon has proved fo favourable as to permit thofe plants which are tender to remain fo long 


\section{The Gardeners Kalendar. Oat.}

abroad, hould now be removed into the ftove the following forts, American Viburnum of feveral forts, Acacias, Apocynums, Incian flowering Reed, Coral tree, Lotus Saneti Jacobi, African Aloes, Torch Thiftes, Malpighia, Tithymals, Hemanthus, Phillyrea Capenfis, Indian Figs, Volkhameria, Protea, Fiddle Wood, Turnera, Solanums, Hibifcus of feveral forts, Jufticia, Tree Phytolacca, Myrtus Zelanica, Euphorbia of feveral forts, and fuch other plants as will bear to be expofed to the open air in fummer: thefe hould be firft placed in the green-houfe for a fortnight or three weeks, where they may have free air; but toward the middle of the month they mut be placed in the fove, where they are to remain during the winter.

Toward the end of the month, as the nights grow cold, you muft begin to malse fres in the ftoves; but this muft be done with caution: for if you make the heat too great, it will caufe the plants to Moot, whereby they will be weakened; and the feafon being too far advanced to permit their hoots to grow ftrong, their leaves will often decay, and fall off. Obferve alfo to refrefl the plants with water pretty often; for when fires are made in the ftoves, they will dry the air of the houfe, and occafion the plants to perfpire more freely than before, whereby 


\section{Oct. The Gardeners Kalendar. 335}

whereby they will require more water: but you muft not give it to them in large quantities, but rather frequently, and no more than is fufficient to reach the fibres of the plants which are toward the bottom of the pots, at each time. When the leaves of any plants decay, they mould be picked off; and the ftove confantly kept clear from fallen leaves, cobwebs, or any other filth; which not only renders the houfe neat, but is very necefrary to preferve the plants in health.

Planis now in Flower in the GREEN-HOUSE and STOVE.

The Scarlet flowering Geranium, Geranium with an Afarabacca leaf, Mefembryanthemi of feveral forts, Cotyledons, Chryfanthemums, Spanin Jafmine, Arabian Jafmine, llex-leaved Lantana, Indian yellow Jafmine, Arciotus, Perfian Cyclamens, Aloes of many kinds, Canary Campanula, Cafia Bahamenfis, Senfitive and Humble Plants, Guernfey Lily, Belladonna Lily, feveral forts of Paffion flower, Leonurus, Euphorbia of feveral forts, Alcea Groflulariz folio, Double flowering Myrtle, Yucca Indica, Polygala arborefcens, Shrubby St. Johnfwort from Minorca, Papaya, Hibif- 


\section{$33^{\circ}$ The Gardeners Kalendar. Oct.}

cus of feveral forts, Senecio fulio retufo, Opuntia, Plumeria, Turnera, Sherardia, Malpighia, Sena Spuria, Limodorum with purple flowers, Solanums, Conyza, Martynia, Clutia, Milleria, Lantana, Rauvolfia, Maranta, Ginger, Coftus, Salvia Africana, Arum caulefcens, Arum fcandens, Spigelia, Diofma, Polyanthes, Crinum, Phytolacca, Piercea, Kleinia, Craffula, African King's-fpear, Phylica, Pancratium, Baffella, Plumbago, Zygophyllum, Acacia, Hæmanthus, Double Oleander, Lotus Sancti Jacobi, Branching After from the Cape of Good Hope with blue flowers, Canary Lavender, Grafs-leaved African Marigold, Volkhameria, Amaryllis with ciliated leaves, with fome others.

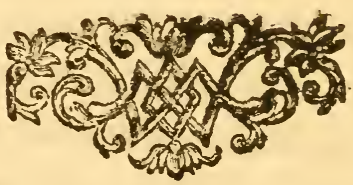




\section{[337]}

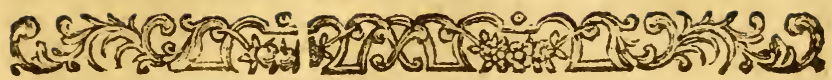

$\mathrm{N} O \mathrm{~V}$ E M B E R.

Work to be done in the K I T C II E NGAR DEN.

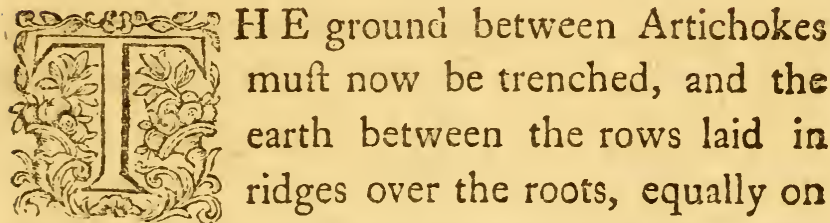
their fides and tops, to prevent their being injured by froft; this will preferve them much better than long dung, which is by fome ignorant perfons ufed for that purpole. But before this is done, the plants hould be cut off quite clofe to the furface of the ground, unlefs where there are fome very ftrong plants which are knit for fruit, which may be tied up with a fmall hayband, and the earth laid up clofe to them, to preferve them from froft; but if afterwards the weather fhould be very fevere, it will be proper to cover them over with 
$33^{8}$ The Gardeners Kalendar. Nov. a little dry litter, which fhould al ways be taken off again when the weather is mild. By this method, fome Articholkes may be preferved all the winter: but if the feafon continues mild, this work thould be deferred to the end of this month, or the beginning of the next: for when they are earthed too early, they are apt to thoot through the ridges of earth before. Chriftmas, and a:e then in danger of being cut off by froft; fo that, where there is but a fmall quantity, which may be earthed in a little time, it mould be done as late in the feafon as the mild weather will permit; but in thofe gardens where there are great quantities, they mutn begin earlier, left the froft thould fet in before they have finithed. Thefe ridges of earth will be fuficient to preferve the Articholses in all common winters; but if the froft happens to be very fevere, it will be proper to lay ftraw, long dung, peas haulm, fern, or tanners bark, over the ridges, which if either of thefe coverings is laid pretty thick, will intirely fecure them from being aeftroyed in the greateft froft; but this covering thould be removed, as foon as the fevere froft is over.

The Áparagus-beds, which were not dreffed the laft month, fhould not be deferred any longer than the beginning of this; therefore the 
Nov. The Gardeners Kalendar.

the haulm thould be cut down, and the weeds fhould be hoed from off the beds in the alleys, where they muft be buried; and the earth of the alleys fhould be fpread over the beds, in the manner directed in the former month.

In mild weather the Cauliflower and Lettuce plants, which are under glafies, or in frames, thould have as much free air as poffible, by fetting off the glafies every day, in dry weather; and, in wet weather,' the glafies fhould be kept over them: but they muft be raifed on one fide with props, to let in as much free air as poffible; for they thould not receive too much wet at this feafon, left it Should caufe them to rot: nor muft they be too clofely covered, left they draw up too weak, which will endanger them, if there hould afterwards be much frofty weather, without fun in the day-time, when they will require to be clofely covered, perhaps for feveral days together.

Sow Peas, and plant Beans, in dry weather, to fucceed thofe which were planted the former month; and draw fome earth to the ftems of thofe Peas and Beans which are come up, which will preferve them from being injured by the froft.

$$
Z_{2} \text { Sow }
$$




\section{$34^{\circ}$ The Gardeners Kalendar. Nov.}

Sow all forts of Sallet herbs upon moderate hot-beds; as Lettuce, Creffes, Muftard, Rape, Radin, Turnep, Ecc. that the table may be conftantly furnithed with them; and in dry weather take up your Endive which is full grown, and lay it into trenches to blanch, obferving always to place it horizontally on the fides of the ridges, that the wet may run off, otherwife it will rot the plants : earth up Celery to blanch it, being careful not to bury the heart of the plants; but this work muft always be done in dry weather.

Dung and trench the ground which is defigned for early crops, laying it in ridges until the time it is wanted, which will be of great fervice to refrem and fweeten the ground; and where the land is ftiff, the froft will mellow and foften it : befides, by getting as much of this work performed as can be conveniently, it will put the work forward in the fpring, when many other things will require to be done.

The beginning of this month fow fome Carrots and Radifhes on warm borders, near pales and hedges, to come early in the fpring, provided it was not performed the latter end of the laft month; if fo, there may be fome more feeds fown the latter end of this, whereby there will be a greater chance of fucceeding. 


\section{Nov. The Gardeners Kalendar. $34 \mathbf{I}$}

The Spinach, Onions, and other crops which were fown in July and Augurt, muft be conftantly kept clear from weeds; which, if permitted to remain at this feafon, will over-fpread the crops, and, by detaining the moifture, caufe them to rot.

Pick all decayed leaves from off the Cauliflower plants, and draw fome earth up to the ftems of thofe which are under bell or handglaffes, being careful not to draw the earth into the heart of the plants, for that will deftroy them.

Make hot-beds for Afparagus to fupply the table at Chrifmas; but thefe will not produce fo large, nor fo many heads, as thofe beds which are made the beginning of January, nor will the Afparagus be near fo well coloured: fo that thofe perfons who are defirous to have green well-coloured Afparagus, hould not make beds at this feafon.

Take up the roots of Carrots, Parfneps, Potatoes, Beets, Salfafy, Scorzonera, Large rooted Parlley, $\mathcal{E}^{2} c$. toward the end of this month, and lay them in fand, in a place where they may be defended from froft, wet, and vermin. For froft and much wet will deftroy them, and vermin will devour the roots; where this is neglected, if the ground hould be frozen up for any con- 
342 The Gardeners Kalendar. Nov. tinuance, there will be no poffibility of getting the roots out of the ground for ufe; and when the froft is over, thofe which were left in the ground will foon decay.

If this month hould prove dry and frofty, you muft carry dung into the quarters of the kitchen-gauden, that it may be ready when you want to dig the ground, which will forward your affairs greatly. The not obferving of this, many times caufes a great hurry of bufinefs together, which fhould be avoided as much as poffible; becaufe, whenever this happens, either fome things are intirely neglected, or are Alighted over too carelefly.

Frefh tie the reed-hedges with ofiers, if they were not done in the former month; otherwife the frong winds which ufually happen at this feafon, will tear them from the fakes, and break the reeds, which will render them troublefome to repair.

Where there are hot-beds eicher for Salleting, Cucumbers, or any other purpofe, they muft be carefully attended at this feafon; for the nights are now long and cold, and the days either frofty, wet, or foggy, fo that little air can be given to them; whereby the plants often grow mouldy, and rot off; and the heat of the Feds is often greatly abated either by rain or fnow, 


\section{Nov. The Gardeners Kalendar. 343}

fnow, which renders it difficult to manage hotbeds at this feafon.

The autumnal Cauliflowers fhould now be carefully looked over two or three times a week, to break down the leaves over thofe whofe heads appear, to guard them from wet and morning frofts, which will difcolour thofe which are expofed thereto, and to pull up thofe whofe heads are full grown, for ufe.

\section{Products of the KITCHEN-GARDEN.}

Cabbages, Savoys, Caulifowers which were fown in May, Browncole or Borecole, fome late Artichokes, Red Cabbages, Spinach, Sprouts of Cabbages, Onions, Leeks Garlick, Rocambole, Shallots, Turneps, Beets, Carrots, Parfneps, Skirrets, Salfafy, Potatoes, Scorzonera, Horfe-radim, Jerufalem Artichokes, Black and White Spanifh Radilhes, Large-rooted Parfley, Sage, Coleworis, Mufhrooms, and, on the hotbedis, fome Afparagus, $\mathcal{C}^{2} c$.

For fallets; Lettuce, Creffes, Turnep, Muftard, Corn fallet, Coriander, Burnet, and other fmall herbs from the hot-bed, or warm borders near walls; as aifo, Endive, Celery, and, if the feafon is mild, fome brown, Dutch, and common Cabbage Lettuces.

$$
\text { Z } 4
$$


344 The Gardeners Kalendar. Nov.

For foups; Beets, Cardoons, Thyme, Celery, Chervil, Marigold, Winter Savory, Hyflop, Sorrel, Parfley, Pot-marjoram, with fome others.

Work to be done in the FRUIT-GARDEN.

If the feafon is mild, you may fill prune Peach trees, Nectarines, Apricots, Pear trees, Apple trees, Vines, and orher kinds of fruit trees, either againit walls, efpaliers, or Anndards; but it is not proper to do it too late in the month, efpecially if the ferfon is inclinable to hard froft and fnow, particularly the tender kinds of ftone fruit ; becaufe gieat fnows, fucceeded by fevere froft, fometimes hurt the branches of the trees, when the wounds are freen; but Pears and Apples are not in much danger of being injured thereby.

You muft now diveft your Fig trees of all their late fruit, which, if left on, will rot and infect the tender branches; then nail the hoots of the trees clofe to the wall, whereby they will be protected from the injuries of the froft much better than if they were left at a diftance from it. You may alfo place fome pannels of reeds before them, if the froit thould be very fevere in winter; which will preferve the young fruiting branches from being killed, and 
Nov. The Gardeners Kalendar. 345

caufe the fruit to come out much earlier the following fpring than thofe which were left open; and thofe Fig trees which grow againt efpaliers, hould be loofened, and their branches may be tied together, and covered with haybands, ftravy, or Peas haulm, to protect them from froft; by which management, a good crop of Figs may be conftantly obtained.

Such fruit trees as were planted the former month for ftandards hould be carefully ftaked, and thore againft walls and efpaliers muft be fattened thereto, to prevent their being difplaced by the violence of the wind, whereby their new fibres, which have been fent forth from their roots fince they were planted, would be deftroyed, to the great prejudice of the trees. You muft alfo obferve to lay fome mulch upon the furface of the ground, about their roots (where it has not been done already), to prevent the froff from penetrating the ground to the roots of the trees.

The beginning of this month tranfplant fruit trees upon a warm dry foil, if the weather is mild; but it would have been better done the former month, becaufe the ground being then warm, the trees put out fibres very foon after planting, which ftrengthens them to endure 


\section{The Gardeners Kalendar. Nov.}

the cold; whereas thofe, which are late planted, rarely take frem rooting until the fpring.

Plant Goofeberries, Rafpberries, Strawberries, and Currants, if the weather is mild; and dig between the rows of Goofeberries and Currants which were formerly planted, to clear the ground from weeds; but you hould firft prune the trees, thai there may be no litter upon the ground afterwards; and if you want ground for kitchen herbs, you may plant fome Coleworts, for fpring ufe, between them.

Clear the Strawberry-beds from weeds and runners, and dig up the alleys between the beds, fpreading a little of the earth between the plants upon the beds, which will greatly ftrengthen them; but if the ground be very poor, it will be proper to fpread a little very rotten dung over the beds, which will be very ferviceable to them.

If any late fruits are. Atill remaining u pon the trees, they frould be gathered the firft dry day; for if they are fuffered to hang longer upon the trees, they will be in danger of perithing by froft and wet: and the fine winter Pears and Apples, which were gathered the lift month, muft now be packed up clofe in bafkets, which hould have double papers at: their buttom, and round their fides; and when 
Nov. The Gardeners Kalendar. 347 the fruit is well placed therein, and double papers over them, there hould be a good covering of wheat ftraw laid over the paper, and then placed where neither the frof nor too much air can get to them, otherwife they are liable to perifh, -or their fkins hrink, in a fhort time.

\section{FRUITs in Prime.}

Pears; Sucre-vert, La Chafferie, La Marquife, Chat-brulé, Le Befidery, Crafane or Bergamot Crafane, Martin Sec, L'Amadote, Louifebonne, Colmar, St. German, Bezy de Chaumontelle, Petit Oin, Virgouleufe, Spanifh Boncretien, Ambrette, with fome others.

Apples; Rennette Grife, Aromatic Pippin, Nonpareil, Golden Pippin, Calville rouge, Calville blanc, Courpendu, Fenouiliette, Herefordhire Pearmain, Holland Pippin, French Pippin, Kentih Pippin, Harvey-apple, Pile's Ruffet, Golden Ruffet, Wheeler's Ruffet, Winter Queening, Winter Permain, Pear Ruffet, with fome others of lefs note.

Bullace, Cheftnuts, Hazlenuts, Walnuts, Medlars, Services, Almonds, with fome iate Grapes. 
$34^{8}$ The Gardeners Kalendar. Nov.

\section{Work to be done in the NURSERY.}

If in the former month could not be compleated tranfplanting all the trees in the nurfery, that work may be continued the beginning of this; for when this is compleated early in the feafon, new fibres will puth out from their roots before winter; whereas all fuch trees as are planted at the end of this month, or in the two following months, felciom put oxt roots until the fpring: the ground being then rendered cold, vegetation is at a ftand, till the warmth of the fpring puts the juices into motion again.

This is the time to lay fome mulch upon the furface of the ground, about the ftems of the new planted trees, to prevent the froft from penetrating to their roots, which often deftroys the young fibres, and greatly weakens, and in a very wet ground frequently kills the trees.

Continue to carry dung into fuch parts of the nurfery as require it, when it is dry weather, and fpread it upon the furface of the ground between the trees, that the rain in winter may wafh the falts into the ground, before it is dug up in the fpring.

Where new plantations are intended to be made in the fpring, the ground hould now be prepared 


\section{Nov. The Gardeners Kalendar.}

prepared by trenching of it well, and laying it in ridges, that the froft may mellow it.

Faften all new pianted trees with ftakes, $E^{2} c$. that the ftrong winds of this feafon may not difplace them.

Where there are hardy exotick trees or Thrubs in pots, they hould now be plunged either into the earth, or fome old tan-bed, in a warm fituation, to prevent the froft from freezing the roots through the fides of the pots, which is often deftructive to them while they are young.

The beds of young feedling exotick trees and Mrubs hould now be protected from fevere froft, by plunging the pots in the manner before mentioned, and by arching of them over with hoops, and covering of them with mats, before the froft is fevere, or by laying fome Peas haulm, or other light covering, over them; which coverings hould al ways be taken off in mild weather.

Work to be done in the FLOWER-GARDEN.

The beginning of this month all the bulbous rooted flowers, which are defigned for planting before Chriftmas, thould be planted; for if they are deferred till late in the month, there is feldom time enough for them to ftrike 


\section{$35^{\circ}$ The Gardeners Kalendar. Nov.}

root before the froft comes on, which will prevent them, fo that they will be in danger of fuffering by this neglect.

The boxes and pots of feedling bulbous rooted flowers thould now be placed in a warm fituation, where they may enjoy the fun, and be fcreened from cold winds.

Cur down the ftalks of fuch late flowering plants as now begin to decay, and rake over the borders of the pleafure-garden, to ftir the furface of the ground, which will prevent weeds and mols from growing thereon; but be very careful not to ftir the earth too deep, left the roots which are under ground hould be thereby injured.

If the feafon concinues mild, you may yet tranfplent Peonies, Monk'smhood, Flag-leaved Irifes, and many other knobed rooted plants, as alfo Lychnifes, Veronicas, Canterbury-bells, London Pride, Fraxinella, Gentianella, Yellow Gentian, Late flowering Starworts and Golden-rods, Wall-flowers, French Honeyfuckle, Honefty, Double Rocket, Double Rofe Campion, and other hardy fibrous rooted plants; though this would have been better if performed the former month; becaufe, if the froft thould fet in foon after they are planted, it will prevent their taking root. 
Nov: The Gardeners Kalendar. $35^{5}$

The beds of feedling bulbous rooted flowers, which were not removed the laft feafon, thould be raked over, to prevent weeds and mofs from growing thereon, if it was not done the former months; and fome frefh earth fhould be fpread over their furface, to prevent the froft from injuring the roots; and when there is danger of very fevere froft, if the beds are covered over with fome rotten tan, it will fecure the young roots effectually from danger.

The pots of choice Auriculas and Carnations muft be theltered from hard rains, froft, and fnow, by coverings either of mats, cloths, or frames where they can be fpared; but where there is not conveniency of either fort, the pots fhould be laid down on one fide, to prevent the moifture from foaking into the earth, which often rots them.

If the feafon continues mild, the following flowering Mrubs may be yet tranfplanted, Rofes, Lilacs, Syringas, Jafmines, Laburnums, Spiræa frutex, Honeyfuckle, Hypericum frutex, Colutea, Bladder Nut, Hydrangea, Rhododendron, Arbutus, Viburnum, Scarlet Horfe Cheftnut, and moft other hardy flowering fhrubs, if the foil be dry where they are to be planted, otherwire it is better to defer it till $\mathrm{Fe}$ bruary. 


\section{The Gardeners Kalendar. Nov.}

Turn over the compoft which have been prepared for pots or borders, that the parts may be equally mixed, and that they may receive the benefit of air and froft, to fweeten them, and render them loofer. And prepare freth compofts at this feafon, that there may not be wanting a fupply the following year; for it is much better to have three or four ftocks under each other, that they may lie the longer, whereby they will be better meliorated and prepared for ufe; for if their parts are not well mixed, the plants will not thrive near fo well which are planted therein.

Toward the latter end of this month, if the feafon hould prove wet or frofty, the beds of choice Anemonies, Ranunculufes, and Hyacinths, which begin to appear above ground, mould be arched over with hoops, that they may be covered with mats or cloths in bad weather, to prevent the froft from penetrating the ground to the roots, and to keep off heavy rains and fnow, which, if permitted to foak into the beds, will often caufe the roots to rot in the fpring : but as the Hyacinth rarely comes up fo foon, the bed, in which they are planted, may be covered with old tan, which will prevent the froft from penetrating the ground, and fecure the roots. 
Nov. The Gardeners Kalendar. 353

The wildernefs quarters thould now be trimmed, and the ground dug between the trees, if it was neglected the former months, which will render it neat, and encourage the growth of the trees; but where there are flower roots growing therein, there muft be care taken not to deftroy them in digging.

In very wet or frofty weather, when little work can be done in the garden, you hould prepare your feeds ready for fowing in the fpring, and make a large quantity of numbers to label your choice flowers; and be fure to prepare your tools of all forts, that they may be ready for ufe when the weather is favourable.

Roll and pole your grafs well at this feafon; for the ground being well moiftened, the roller will prefs the ground clofe, which will make the grafs fine and be a great advantage to the fward.

Keep the gravel walks clean from weeds and mofs, for at this feafon they will fpread greatly, fo will be difficult to eradicate in the fpring.

\section{Plants in Flower in the open Air.}

Some forts of late Starworts, two or three forts of Golden-rods, Annual Stock-gilliflower, Double Colchicum, Heart's-eafe or Panfies, 


\section{The Gardeners Kalendar. Nov.}

three or four forts of Perennial Sun-flowers, Plumbago or Leadwort, Indian Scabious, Iron coloured Fox-glove, Old Man's-head Pink, Antirrhinum, Tanfey-leaved Ox-eye; and, if the feafon is mild, fome Single Anemonies, and Polyanthus Narciffufes, where they were not removed the lant fummer; as alfo the Purple Ragwort, Eupatoriums, Clinopodiums, and Helenias.

Hardy Trees and Sbrubs now in Flower.

Arbutus, or Strawberry tree with flowers and ripe fruit, Lauruftinus, Mufk-rofe, Paffion flower, Clematis Bœtica, Medicago frutefcens, Genifta fpinofa, and, in mild feafons, the Eaftern Colutea, Diervilla, Pyracantha, Cretan Mefpilus, and two forts of Euonymus in fruit.

MEDICINAL PLANTS rebich may nory be gatbered for UJe.

Calamus Aromaticus roots, Iris roots, Afparagus roots, Swallow-wort roots, Beet roots, Elecampane roots, Eryngo roots, Fennel roots, Henbane root, Artichoke roots, Savin, Scorzonera root, Skirret root, Tormentil root. 


\section{Nov. The Gardeners Kalendar.}

Work to be done in the GREEN-HOU S I and $\mathrm{S} \mathrm{T} O \mathrm{~V} \mathrm{E}$.

The beginning of this month all the hardy exotick plants which have been permitted to remain abroad till this time, but which require protection in winter, fhould be removed into the green-houfe, or the place defigned for them in winter; and now it is full time to place the plants in the green-houfe, in the order they are to remain all the winter; in doing of which, obferve to place the talleft plants backward, and to let them llope down gradually toward the front; but they fhould not be placed fo clofe as that their branches may interfere, for that would greatly injure their heads.

In mild weather the hardy exotick plants Thould have as much free air as poffible admitted to them, by opening the glaffes every day ; and the plants fhould be daily looked over, to fee which of them want water; for there are fome forts of plants which will require to be watered three or four times in a week, when many others do not require it above once; fo they muft not be all watered at the fame time, but only thofe which require it; this thould alfo be performed in a morning, that the damp 


\section{$35^{6}$ The Gardeners Kalendar. Nov.}

may pafs off before the windows are clofe thut in the evening, otherwife the damp occaficned thereby will injure the plants.

You hould alfo frequentiy pick off all decayed leaves from the plants, and not permit them to fall among the pots and tubs, which make a litter in the houfe, and, as they rot, will infect the air, which being imbibed by the plants, will caufe them to change the verdure of their leaves to a pale fickly complexion.

As the cold advances, the fires in the ftove fhould be increafed proportionably, being careful not to over-heat the air, left thereby the plants thoot too freely, which is injurious to them at this feafon; nor thould the air be too cold, left their leaves decay and fall off, and the extreme parts of the plants perim : therefore the fuccefs in managing tender exotick plants, greatly depends on keeping the air of the ftove in a proper temperature of heat, and in duly proportioning the quantity of water given to them at this feafon of the year.

In winter pick off all decayed leaves from the tender plants in the frove, and clean their leaves and ftems from filth, which they are very fubject to contràct, and waih off all infects, which often infert many of the forts, but ef- 
Nov. The Gardeners Kalendar. 357 pecially the Coffee tree, which will require to be frequently cleaned.

The Anana or Pine apple plants muft not be fuffered to remain longer in the bark-beds under frames than the beginning of the month, at which time they fhould be removed into the ftove, obferving to do it in a warm day, and place them where they may have a great thare of heat, without which they feldom produce fruit : this is only to be underftood of fuch as are kept in a dry ftove in winter; for where there is a tan-bed in the ftove, the plants muft be placed therein before this time.

Plants in Flower in the GREen-House and STOVE.

Several forts of Aloes, fome Geraniums, Sedum arborefcens, Cotyledons, Arctotufs, Phylica, Leonurus two forts, Canary Campanula, Candytuft tree, Yellow Indian Jafmine, Indian Nafturtium with a double flower, Spanih Jafmine, American and Ilex-leaved Lan. tana, Senecio folio retufo, Large Blue Virginian Starwort, Double-flowered Myrtle, Caffia Bahamenfis, Papaw tree, Chryfanthemum arborefcens, African Shrubby Doria, Perennial Buphthalmum, Canary Bafe-horehound, In- 


\section{The Gardeners Kalendar. Nov.}

dian Flowering Reed, Malpighia mali punici facie, Cacalia, Senfitive Plants, Azorian Jafmine, Clutia, Tetragonia, feveral forts of Mefembryanthemi, Craftulas, Guajava, Poinciana, Crinum, Melocactus minor, Piper, Arum fcandens, Turnera, African Shrubby Sage with blue flowers, Perfian Cyclamen, African Afphodel, Gnaphalium two or three forts, Teucrium Bœticum, Heliotropium Canarienfe, Apocynums, Oriental Ptarmica, Chryfocoma, Stcechas with fawed leaves, two or three forts of Paffion flower, African Shrubbry Mallow, Shrubby Helictrope from Peru, Branching China Starwort, Crinum with blue umbellated flowers, African Wood Sorrel with large purple flowers, Anthericums, Shrubby Phytolacca from Peru, Adhotada or Snap tree, Uermannias, Diofma, Mexican Clary, Guernfey Lily, Belladonna Lily, with fome others.

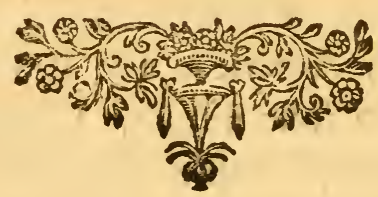




\section{[359]}

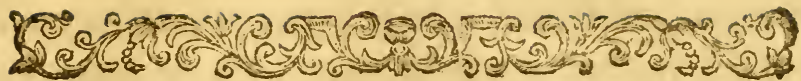

\section{E C E M B E R.}

Work to be done in the KITCHENGARDEN.

Faneren HIS month (the days being at 5. (5) (5) mortent) is commonly the (2) darkert of the whole year, and so fubject to different forts of weather; fometimes the ground is frozen up, fo that little can be done in the garden; and at other times there are hard rains and thick ftinking fogs, which render it very uncomfortable ftirring abroad, but efpecially to perfons of tender conftitutions; and this weather is alfo very injurious to tender plants.

If this feafon is mild, you may earth up thofe Artichokes which were neglected the former months; in doing of which, if the ground is not very good, bury fome rotten dung in it, which will greatly promote the growth of the Artichokes the following fpring.

$$
A \text { a } 4
$$

Carry 
360 The Gardeners Kalendar. Dec.

Carry dung into the quarters of the kitchengarden, and fpread it on the ground, and trench up the quarters, where there are no crops on the ground, laying the earth in ridges, that it may be mellowed by front, and be fit for ufe when the feafon for cropping the ground comes on; for if this is neglected in winter, there will be fo much other bufinefs to do in the fpring, that there will not be time to trench the ground properly, which frequently occafions its being flightly performed.

Pick fnails out of the holes of old walls, or frum under pales, hedges, broken pots, or other rubbih ; as alfo behind the ftems and branches of wall fruit trees, in which places they lay thémfelves up during the winter feafon, and may be then eafily taken before they get abroad again.

Sow Crefles, Muftard, Rape, Radih, Turnep, and other fallet herbs, upon a moderate hot-bed, which fhould be either covered with frames, or arched over with hoops, and covered with mats; for at this feafon thefe feeds will not come up, where they are expofed to the open air.

In mild weather obferve to uncover the Cauliflower plants under frames every day, that they may enjoy the free air, otherwife they 
Dec. The Gardeners Kalendar. $\quad 36 \mathbf{t}$ will draw up week; and conftantly pick off all decayed leaves, which, if fuffered to remain on, will be very injurious to the plants; efpe. cially if it thould happen, that the weather will not permit the beds to be uncovered for two or three days together; which is often the cafe at this feafon, in hard frofts, when thefe decayed leaves, rotting in the beds, will emit a rancid vapour; which, mixing with the confined air of the beds, will render it unwholfome for the plants.

Earth up Celery to blanch it; but this muft be done in dry weather, otherwife it will rot the plants. At this time it hhould be earthed up as near the tops of the plants as poffible, to protect it from froft; and at the approach of hard froft, it will be neceffary to cover fome Celery and Endive with fern, ftraw, or peas haulm, to prevent the ground being frozen, otherwife it cannot be taken up during the froff's continuance in the ground. And earth up Cardoons as near their tops as poffible, for the fame reafon.

In mild weather take up Endive in a dry day, and hang it up in a dry place for two or three days, that the moifture may drain from between the leaves; and then lay it in ridges on a dry fpot of ground borizontally to blanch it, obferving 


\section{The Gardeners Kalendar. Dec.}

obferving to clofe the leaves up regularly, and put it into the ground, almoft to the tops of the plants.

You may now make hot-beds for Afparagus, to fupply the table about the latter end of January; for, at this feafon, it will be near fix weeks from the time of making the beds, before the Afparagus will be fit to cut, if the beds are of a due temperature of heat.

A bout the middle of this month, if the weather is mild, fow fome early Peas on warm borders, to fucceed thofe which were fown the former months; and obferve to draw fome earth up about the ftems of thofe Peas and Beans which are come up, and in bad weather cover them with ftraw or reeds, to protect them from the froft; and if fome old tan is laid over the furface of the ground about their ftems, it will prevent the froft from penetrating the ground, and greatly protect the plants.

Take up Cabbages and Savoys which are defigned for feed, and hang them up in a dry room by their ftalks for a week or ten days, to drain them of moifture; and then plant them down in a warm border, almoft over their heads, leaving only the upper part of their heads above ground; but the earth fhould be raifed in a hill about each, the better to throw off the 


\section{Dec. The Gardeners Kalendar. $\quad 363$}

wet, which if detained about them, will caufe them to rot: but in the planting of thefe, there fhould be particular care taken to plant each kind feparately at a difance; for when they are planted near each other, the farina of the flowers will intermix, whereby their feeds will be degenerated: and if after they are planted the froft fhould prove fevere, it will be proper to cover them over with dry frraw or peas haulm, or fern, to keep out the froft f for where this is neglected in hard winters, they are frequently deftroyed.

Sow fume Radifhes, Carrots, and Lettuce, on warm borders near walls or pales, for an early crop, becaufe it may happen that thofe which were fown the former months may be deftroyed, and thefe may efcape; for which reafon it is proper always to have two or three crops, one under the other, which will allow a better chance than where there is but one.

Toward the latter end of this month plant fome Sandwich and Toker Beans, which ate hardier than the Windfor kind, and will be very proper to fucceed the Mazagan or Lifbon Beans, which were planted the former months, fo that there may be a conftant fupply for the table. 


\section{The Gardeners Kalendar. Dec.}

When the ground is frozen fo hard that it cannot be dug, the fences of the garden may be repaired where it is neceflary ; dung hould be carried into the quarters, that it may be ready when the froft goes off; and where perfons have any feeds remaining in their pods or capfules, they hould now be made clean and ready for fowing; and prepare all tools fit for ufe, that there may be no delay, when the feafon is favourable, for cropping the ground.

You muft. now be very careful of your Muhroom-beds, to cover them with frem dry ftraw, fo thick as to keep out the froft and wet, both which are injurious to thefe beds; but where proper care is taken, there will be a conftant fupply of thefe for the table in the mort rigorous feafons.

Products of the K I T CH EN-GAR DEN.

Cabbages, Savoys, Red Cabbages, Borecole, fome Cauliflowers, if the feafon proves mild; Purple and White Broccoli, Carrots, Parfneps, Turneps, Potatoes, Skirrets, Scorzonera, Salfafy, Beets, Large-rooted Parfley, and Horferadifh.

Onions, Leeks, Garlic, Rocombole, Shallots, Thyme, Winter Savory, Hyflop, Sage, Rofemary, 


\section{Dec. The Gardeners Kalendar. 365}

mary, Chard Beets, Cardoons, Celery, Endive, Sorrel, Turnep-rooted Cabbage, Parlley, Chervil, and fome other herbs for foup.

For fallets; Creffes, Muftard, Rape, Radin, Turnep, fmall Lettuce, and other fallet herbs, upon the hot-bed; Celery, Endive, Burnet, and fome Brown Dutch Lettuce from under glaffes in mild weather; with Mint and Tarragon upon hot-beds made the beginning of laft month, and Afparagus upon hot-beds made in Ostober.

Work to be done in the FRUIT-GARDEN and O R C H A R D.

If the feafon proves mild, the ground defigned for planting fruit trees in February, Chould now be trenched for that purpofe, and the borders of the fruit-garden hould be mended where they require it, with fome frefh earth, and very rotten dung well mixed together, which will greatly encourage the growth of the trees, and alfo add to the fize and goodnefs of their fruit.

It will not be proper to prune fruit trees, either againft walls or efpaliers, at this feafon, unlefs it thould be very mild weather, left the froft hould follow foon after, which would injure 


\section{The Gardeners Kalendar. Dec.}

injure the wounded branches, efpecially of Peaches, Apricots, and other tender ftone fruit trees.

Examine the trees in orchards, and cut out all dead branches out of them, as alfo fuch as crofs each other; in doing of which obferve to make the wound floping, and as fmooth as poffible, that the wet may the eafier pafs off without entering the wounds of the tree; but thefe branches thould be cut off clofe to the ftems, and not left in fpurs, as is by fome unfkilful perfons too often practifed.

Dung and plough the ground of Orchards between the ftandard trees, which will be of great fervice to them, and caufe the fruit to be much fairer, and better tafted.

The Vines in the vineyard Thould now be pruned, if it was not done the former month; for where there is much of this work to perform, it Mould be begun as foon as the leaves fall, otherwife it may occafion part of them to be left undone till the fpring, when the fap will flow out at the wounds, and weaken the plants.

In frofty weather be careful to cover the ground about new planted irees with mulch, to prevent the froft from penetrating the ground 
Dec. The Garcieners Ralendar. $\quad 367$

to their roots, for that would greatly injure the young fibres.

You muft alfo be very careful to keep the froft out of the room where the choice winter fruits are put up; for whenever any of the fruit are frozen, they certainly decay foon after. Where orchards or nurferies are inclofed with quick hedges, thefe may now be trimmed ; and if they are grown thin, they may now be plaihed and laid fo as to make the fences clofe at bottom.

\section{FRUITs in Prime.}

Pears; the Colmar, St. Germain, St. Andrew, Virgouleufe, Ambrette, Lefchafferie, Epine d'Hyver, St. Auguftine, Beurre d'Hyver, Louife-bonne, l'Amadotte, Spanim Boncretien, Poire de Livre, Ronville, Citron d'Hyver, Roufellette d'Hyver, Martin Sec, Holland Bergamot, Mufcat d'Alleman, Bezy de Chaumontelle, with fome others.

Apples; the Nonpareil, Golden Pippin, French Pippin, Holland Pippin, Kentifn Pippin, Pile's Ruffet, Winter Pearmain, Wheeler's Ruffet, Haute-bonne, Rennet Grife, Aromatic Ruffet, Winter Gilliflower, Golden Ruffet, Pear Ruffet, Harvey Apple, Winter Queening, with fome others of lefs note. 
368 The Gardeners Kalendar. Dec.

As alfo Medlars, Services, Almonds, fome Grapes, where they have been carefully preferved, Cheftnuts, Walnuts, and fmall Nuts.

Work to be done in the NURSERY.

In this month and the next it is very unfafe to tranfplant trees; therefore little can be done in the nurfery, except carrying in dung where it is wanted; and in mild weather to prepare the ground, where trees are defigned to be planted in the fpring.

Obferve now to lay mulch about the ftems of new planted trees, where it has been omitted in the former months; otherwife the froft will enter the ground, and pinch all the new fibres, whereby the trees will be greatly weakened.

In frofty weather look well to fuch nurferies as are expofed to hares, rabbets, $\xi_{C}$. for in fuch feafons thefe animals will be apt to bark young trees, and fpoil them.

If the weather is mild, continue to dig between the rows of trees in the nurfery, where it has not been already done; obferving, as was before directed, not to injure their roots.

Be careful alfo to fecure fuch young exotick trees as have not ftrength to refint the cold of our climate, by laying mulch round their ftems, 


\section{Dec. The Garaeners Kalendar. 369}

and in fevere froft cover their tops with peas haulm, fern, ftraw, or other light covering; but this muft not remain after the froft is over, leaft it caufe a mouldinefs upon the tender thoots of the plants for want of the free air.

Cover the beds of feeds and Acorns, which were fown in October, fo as to prevent the vermin from getting at them; and alfo to keep the froft out of the ground, which might greatly injure fuch of them as are fprouting.

You hould now plath hedges round your nurfery or orchard, and repair your other fences, for this is the moft leifure time of the whole year in the nurfery.

Work tó be done in the PLEASURE-GARDEN.

The beds of choice Ranunculufes, finemonies, and Hyacinths, hould be carefully covered in very wet or frofty weather, both which are equally prejudicial to them.

The pots or boxes of feedling flowers thould alfo be covered in very hard rains or fevere froft, otherwife they will be in danger of being deAtroyed thereby.

Cover the choice Carnations and Auriculas, to protect them from great rains and fnow, which are very injurious to them; but in mild 


\section{The Gardeners Kalendar. Dec.}

weather they Thould have as much free air as poffible; otherwife they will draw up weak, and become very tender.

Lay fome mulch about the roots of new planted trees and thrubs, as alfo about exotick trees, which are planted in the open air, to prevent the froft from penetrating the ground to their roots, which would greatly injure, if not deftroy them.

Turn over the feveral heaps of earth which are prepared for the flower-garden, that the froft may mellow them; and mix up fome new heaps, that there may be a quantity always prepared eight or ten months, at leaft, before it is ufed.

In mild weather dig and prepare beds and borders ready for planting flower roots in the fpring; in doing of which, it will be proper to lay the earth up in a ridge, that the heavy rains may run off, which would render the earth too wet for planting, if the beds were laid flat to receive all the moifture.

Continue to dig up the ground in the wildernefs quarters, that the whole may be rendered neat againft the next fpring, when the trees begin to bud, and the flowers blow, which will invite perfons to walk out; but in doing of this, there mutt be care taken not to injure 
Dec. The Gardeners Kalendar. $37 \mathbf{I}$ any of the plants which grow between the trees.

Prepare fuch parts of the garden in which fowering Thrubs or tender forts of exotick trees are defigned to be planted in the fpring: but this ground thould be laid in ridges till the feafon for planting is come, that it may mellow and fweeten.

In hard frofty weather, when little work can be done in the garden, except the covering and uncovering of tender plants and Mrubs, prepare the tallies to number flowers and feeds when they are planted or fown, and make all the tools ready for ufe againft fpring, when there will be full employment abroad.

\section{Plants now in Flower.}

Some fingle Anemonies, Polyanthufes, Primrofes, Stock-gilliflowers, Narciffufes, Helleborafter or Bear's foot, Alyfion Halimi folio, Red flowered Spring Cyclamen, Tangier Fumitary, Narrow leaved Golden Rod; and in mild weather fometimes the Winter Aconite, and Snowdrops toward the end of the month.

$$
\mathrm{B} \text { b } 2
$$


372 The Gardeners Kalendar. Dec.

Hordy Trees and Sbrubs now in Flower.

Lauruftinus, Arbutus or the Strawberry tree, in flower with ripe fruit, Spurge Laurel, Glaftonbury Thorn, Virginian Groundfel tree, Upright blue-berried Honey-fuckle, Genifta Spinofa, Clematis Bœtica, Medicago frutefcens, and, in mild weather, the Mezereon, and the Pyracantha in fruitor

Medicinal Plants which may now be gatbered for UJe.

Beet root, Elecampane root, Fennel root, Henbane root, Helleborafter or Bear's foot, Lovage root, Spignel root, Butterbur root, Hogs Fenrel root, Harts Tongue, Polypody root, Solomon's Seal root, Savin, Sopewort root, Scorzonera root, Skirret root.

All thele roots may be taken up, whenever the froft does not prevent it: for as moft of thefe piants are, at this feafon, in an inactive ftate; fo they are in the greatelt perfection, either for medicine, or the table. 


\section{Dec. The Gardeners Kalendar. 373}

Work to be done in the GREEN-HOUSE, and STOVE.

If the feafon is very cold, keep the windows and doors of the green-houfe clofely hut; and in frofty nights the Chutters thould be duly faltened to prevent the froft from entering; but in mild weather they thould be opened every day, to give light to the plants; and when there is fun in frofty weather, and the air is warmed, fome of the glaffes hould be drawn down, to let frefh air into the houfe : but this fhould be done with caution, for at this time of the year, there is frequently a damp moift air, which if pent up in the houfe will caufe the tender hoots of the plants to grow mouldy and decay; therefore whenever auy mouldinefs appears upon the plants, it hould be immediately cleaned off ; otherwife it will fpread, and infect the neighbouring plants : and diligently pick off all decayed leaves, never fuffering then to fall upon the floor, or at leaft do not let them remain in the houfe, for they will rot and infect the air, to the injury of the plants.

The plants thould now be watered very fparingly, efpecially fuch of them as are of a fucculent nature; as Aloes, Cereures, Sedums, B b 3 Euphorbia, 


\section{The Gardeners Kalendar. Dec.}

Euphorbia, Cotyledons, $E^{2}$. but the Myrtles, Amomum Plinii's, Leonurufes, Oleanders, Bays, Adhatoda, with many other woody plants, muft be frequently watered; but in cold weather they should not have too much given them at a time, but rather give it them often, and in lefs quantities, fo as only to prevent their leaves from thrinking and curling up.

The fires in the ftoves muft now be carefully kept up, as well in dark foggy weather as in fevere froft; for if the air is damp, it is equally injurious as a fharp air to the plants; fo that in this you muft be directed by a well graduated thermometer, as to the degree of heat which the plants require.

The Ananas, or Pine apples, muft have a good thare of heat, otherwile they will not produce fruit the following fummer: they will alfo require to be refrefhed often with water, which thould be given to them in fmall quantities at this feafon, which hould be placed in the frove to warm, at leaft twelve or fourteen hours before it is ufed: where this watering is neglected, or unikilfully performed, the plants are often fo checked, as not to be recovered in fome months after.

The tender exotick plants, which are plunge ed in the bark-bed, muf now be carefully

tended, 


\section{Dec. The Gardeners Kalendar. 375}

tended, to water them as they thall require it ; and pick off all decayed leaves, and clear them from infects and filth, which they are fubject to contract, efpecially the Coffee trees, which muft be often cleanfed, otherwife their leaves will decay.

Mix up the feveral compolts of earth for the exotick plants, and turn over thofe heaps which have been already prepared, that their feveral parts may be better united together.

Plants now in Flower in the GREEN-HOUSE and S T O V E.

Leonurufes, Candy-tuft tree, Yellow Indian Jafmine, Aleppo Cyclamens, Afcyron Balearicum, Geraniums, Spanifh Jafmine, Arabian Jafmine, Ilex-leaved Lantana, Polygala arborefcens, Double flowered Indian Nafturtium, Onion-leaved Afphodel, feveral forts of Aloes, Aretotus, Canary Chryfanthemum, Rudbeckia, Dwarf Sunfower, Canary Campanula, African Shrubby Mallow, Piercea in flower and fruit, Virginian large blue After, Senecio folio retufo, Phylica, Diofma, fome forts of Mefembryanthemi, Senfitive Plants, Indian flowering Reed, Malpighia mali punici facie, Elichryfums, Teucrium Bœticum, Heliotropium Scorodoniæ folio, Clutia, Plumbago Cey$\mathrm{B} \mathrm{b} 4 \quad$ lanenfe, 
376 The Gardeners Kalendar. Dec. lanenfe, Oriental Ptarmica, African Wood Sorrel with large purple, and with yellow flowers, Black flowering Lotus, Mexican Clary, Heliotrope from Peru, Sedum arborefcens, Zygophyllum. Calendula-Africana, A pocynums, with fome others; and in fruit Lycium Pyracanthæ foliis, Solanums of feveral furts, Alkekengi, Amomum Plinii. 


\section{I $\mathrm{N}$
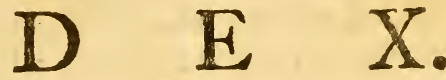

A.

Butilon 208, 299. Acacia 96, 136, 166,

$173,198,233$, $24 \mathrm{I}, 272,334,336$.

Acanthoides 24I.

Acanthus 195, 230, 266, 292, 329.

Achillæa 232.

Aconite 26, 6r, I9r, I95, $230,265,292,294,37 \mathrm{I}$. Acorn 120, $317,369$.

Adders-tongue 1067.

Adhatoda 208, 242, 358, 374 . Adonis 61, 91, 95, 123,165 , 195, I97, 231, 263, 264 . African 191, 196, 264, 293, 328.

Agnus Caftus 233, 242, 266, 294, 329.

Agrimony 199, 234.

Alaternus 27, 62, 93, 94, I I $9,128,156$.

Alcæa 197, 242, 265, 272, $299,335$.

Alder 319.

Alexander 247.

Alifander 28, 77, I13, 199, 247,295 .

Alkekengi I9I, 208, 294, 376.

Almuid 20, 95, I 30,166 , $315,324,347,368$.
Aloe $34,35,72,73,104$, $135,170,174,206,207$, $242,268,272,299,331$, $332,334,335,357,373$, 375 .

Althæa 197, 233, 266, 324, 329.

Alyfion 27, 62, 95, 129, 165, $232,265,294,321,329$, 371.

Amaranthus 25, 60, 92, 93 , I24, I 59, I6I, I9I, 228, $231,264,328$.

Amaryllis 35, 105, 127,158 ,

$173,242,328,336$.

Amber 96, 17 1, 236, 242, 299, 33I.

Ambrofia 265, 273, 294. Amelanchier I 30, 166.

Amethyltea 232.

Amomum Plinii 35, 100, 102, $207,240,299,374,376$. Amorpha 198.

Ananas 33, 43, 7 I, 102, I34, $172,187,205,230,238$, $269,284,333,357,374$. Anaftatica 228.

Andromeda 267 .

Androface 105.

Anemone 21, 23, 26, 58, $61,89,95,127,129$, $157,161,163,192,262$, $289,290,29 \mathrm{I}, 320,328$, $352,354,369,37$ I.

Angelica 


\section{$I N \quad \mathrm{D} E \mathrm{E}$.}

Angelica 247, 266.

Anonis 130, 167, 208, 233 , $24 \mathrm{I}, 265,273,294$.

Anthericum 1 35, 165,174 , $208,243,300,358$.

Antholyza 74, 105, 136,174, 203.

Anthora 230.

Antirrhinum 230, 265, 354 .

Apocynum 35, 173, I 95, 232, $236,264,272,292,299$, $32 \mathrm{I}, 334,358,376$.

Apple I 4, 20, 55, 65, 85, 88 , $118,154,187,22 \mathrm{I}$, $255,284,310,315,344$, $346,347,367$.

Apricot 84, 116, 119, 148, $153,183,18 \%, 188,222$, $309,344,366$.

April 106.

Arbor Judæ 96, I30, 166. Arbor Vitæ 62.

Arbutus 94, 156, 293, 294, $324,329,35^{1}, 354,372$. Arcinangel 167 .

Arctotus 35, 73, 104, 135,

I $7 \mathrm{I}, 173,201,207,236$,

$272,299,331,335,357$,

375 .

Argemone 265.

Aria Theophrafti $\mathbf{3 0 ,}$ I66.

Arrow-root 272, 299.

Arfefmart 267.

Artichoke 2, 40, 46, 50, $8 \mathrm{I}$,

$84,108,112,144,145$,

$147,183,214,216,248$,

$25^{2}, 281,306,309,337$,

$338,343,354,359$.

Arum 27, I29, 136, 165,

I $74,208,267,273,295$, $300,330,336,358$.

Alarabacca $27,62,164,330$.
A farina 165 .

Afarum, fee Ararabacca.

Afclepia 207, 208, 24I, 265, $299,328$.

Afcyrum 35, 208, 375 .

Afh 62, 96, 130, 166, 167, I99, 330 .

Apparagus $3,8,9,13,27$, $4 \mathrm{I}, 45,46,50,79,84$, II $3,114,147,182,183$, 213, 250, 278, 301, 302, $307,308,338,34 \mathrm{r}, 343$, $354,362,365$.

Afphodel 35, 164, 173, 196, $242,321,358,375$.

After 88, 160, 194, 292, $293,32 \mathrm{I}, 332,336,375$. Aftralagus 123, 23I, 266, 321 .

Atraphaxis I74.

Avens $165,167,199$.

Auguft 244.

Auricula 24, 26, 56, 57, 89, $90,95,125,126,127$, I29, $161,229,259,260$, $262,290,323,328,35 \mathrm{I}$. Azalea 267, 295, 269. Azederach 233, 267 .

B.

Baccharis 27, 35 .

Bachelors-button 58, 165 , I $96,263$.

Balfamine 60, 92, 124,159 , I6I, I9I, 196, 230, 231, 26I, 264, 293, 328.

Barba Jovis $207,240$.

Bark-bed 102, 1 33, 1 72, 258,

296, 333 .

Barleria 300.

Barley 82. 


\section{N D E X.}

Bafil Igr, 216, 234, 253, $265,267,28 \mathrm{r}$.

Baffella $35,173,207,241$, $272,300,336$.

Balteria 167, 208.

Bauhinia 173,300 .

Baum 78, 84, 147, 183, 216 , 23I, 253, 308 .

Bay 93, 96, 100, Ior, I19, I $31,156,332,374$.

Beech 317 .

Bean-caper 196, 208, 299, $32 \mathrm{I}$.

Bean-flower 167 .

Beans 2, 4, 12, 36, 37, 40, $48,76,108,110,137$, $139,140,147,175,182$, $183,209,213,216,2.32$, $252,279,281,294,303$, $339,362,363$.

Bears-breech 167 , 199, 234, 267.

Beets I 2, I 3, 27, 36, 45, 50, $77,83,143,176$, $216,250,253,281,309$, $330,341,343,344,354$, $364,372$.

Bell-flower 88, 225, 289, fee

Campanula.

Belly-ache-weed $24 \mathrm{I}$.

Benjamin tree 95, 130.

Berberry I 30, 295, 330.

Bermudiana IC5, 242.

Betony 167, 197, 198, 199. Bignonia 233, 266, 273, 329 .

Bilberry I 30.

Birch tree.63.

Bird Cherry I30, 166.

Birds-eye 164 .

Birthwort 27, 74, I64, I 74, rg. 6.

Bifhop fweed $26 \%$

Bifierula 266.
Biftort 27, 164 .

Bladder-nut I30, I66, 324, $35 \mathrm{I}$.

Bladder Sena I97, 233, 266, 295, 324, 329.

Blattaria $195,265$.

Blue bottle 167, 199, 32 г.

Borage $77,95,114,147$, $165,167,183,199,216$.

Borbonia 208.

Borecole 12, 50, 83, 309, 343.

Box edging 59, 226, 288, 322.

Box tree 27, 62 .

Bramble 324 .

Brimy 27, 267.

Broccoli I3, 50, 83, II 3 ,

$145,145,178,180,210$,

$215,248,280,306,309$, 364 .

Brooklime 96, I 31, I67, 199. Broom 167, 173, 197, 199, $207,232,233,241,266$, 295.

Brown Jolly 159.

Brunsfellia 208.

Buckthorn 95, 166, 324.

Buglors 27, 7\%, 147,165 , $167,183,195,199,216$, $234,265,294,328$.

Bugule 129, I $31,167$.

Bullace $315,347$.

Buphthalmum 88, 162, I65,

$231,266,272,328,332$,

357.

Bupleurum 208, 243.

Burnet I $3,50,77,84,1)_{3}$, $148,167,177,183,198$,

$216,253,281,343,365$. Butterbur-root 28, 3\%2. Button-tre: $16 \%$ 


\section{I $N$ D $E$ X.}

\section{C.}

Cábbage $8,9,12,36,39,44$, $45,50,70, \& 3$, IIO, II I, I I 2 , I I 3 , I I A , I 40, 144 , $146,147,175+183,210$, $213,216,215,-50,276$, $277,281,321,304,300$, 3i $3,34 \hat{3}, 362,364,365$. Cacis!a $32,35,73,36,273$, $35^{8}$.

Cactus 236.

C.lamint 199, 234.

Calanus 295, 330, 354.

Cincin ula 129,376 , fee $\mathrm{Ma}$ rigold.

Calla $74,105,173$.

Camomile 78, 195, 199, 231, $289,293,321$.

Campanula $35,58,88,91$, 92, $104,164,104,197$, $203,207,231,204,292$, $204,321,329,331,335$, 357,375 .

Cana y Lavender 208, 336.

Candy-tuftg1, 105, 1 23,135 , I $59,174,196,231,264$, 294. $299,332,357,375$.

Canna $105,272,299$.

Cannacorus $136,232$.

Canterbury-bell 58, 88, 92, $124,160,194,225,321$, 350.

Caper 169, 198, 243, 273, 209.

Capnoides 195, 265.

Capficum 80, 92, I 47, I 59, $191,196,231,253,265$, $267,293,295$.

Cardifpermum IgI. Cardoons $13,50,81,83$,
I80, 275, 28r, 302, 309, $344,361,365$.

Carduus benedictus I80, I99. Carnation $24,25,56,88$, $90,124,125,160,163$, I9I, I93, 194, 225, 226, $227,230,258,259,264$, $287,291,323,351,369$.

Carob r 31 .

Carmgana 167.

Carrot 2, 9, I0, 12, 36, 37, $45,50,77,79,83,108$, $I_{4}, 143,146,147,155$, $183,210,216,252,267$, $276,280,281,295,303$, $307,309,340,341,343$, 363,364 .

Carthamus I 23, 266, 293.

Cafhinberry-buh 267.

Caffia 35, 104, í74, 208, $241,272,300,335,357$. Cafida I96, 232, 321 .

Cafline 93, I 99 .

Catalpa $198,233,267,324$. Catananche 92, 231, 265, 294.

Catchily 58, 91, 92, 123 , $159,164,195,196,263$, 289.

Caterpillarplant 92, i $23,159$.

Cat-mint $198,234$.

Cats-foot $129,164$.

Cauliflower 5, 6, 7, 39, 46, $47,76,109$, I 10,139 , $140,142,147,175,176$, $177,182,183,209,210$, $216,245,253,274,276$, $278,279,303,305,309$, $339,341,343,360,364$. Ceanothus 233.

Cedar 93, 94, 96, 99, I19, $120,122,156$.

Celandine 


\section{N D E X.}

Celandine 27.

Celaftrus 105, I 7 I, I 74, I98, $208,233,242,267,295$, $33 \mathrm{I}$.

Celery 4, 45, 50, 76, 84, I09, II 2, I I $3,140,178$, $183,210,212,214,2.16$, $246,248,252,276,280$, $28 \mathrm{I}, 302,309,340,343$, $344,361,365$.

Centaurea 123, 124,196 , $230,23 I, 265,266,294$, $300,321,328$.

Cerafus, fee Cherry.

Cereus 34, 105, I36, 169, I 74, 202, 208, 236, 24 I, $268,271,273,373$.

Cerinthe $263,265,294$.

Ceftrum 35, 174, 272, 300.

Chamælxa I 66.

Chard Beet II3, 28r, 300, 365 .

Chafte-tree 273.

Chelone 23I, 294, 329.

Chenopodii 250.

Cherry 27, 53, 65, 95, 102, I 19, I 53, I 54, I84, I87, $222,234,284$.

Cherry (double flowering) I $30,324$.

Cherry Plum 95, I 30, 324.

Chervil I2, I 3, 50, 77, I14, $148,167,216,247,277$, $281,309,344,365$.

Cheltnut 64, I30, I98, 347 , 368.

Chickweed 62, I 37.

China Pink 231, 293, 328.

China Rofe 136.

Chinquapin 96.

Crironia I 74, 208, 242, 273, 299, 33I.

Chriftophcriana I96.
Chryfanthemum $88,162,164$, 173, 191, 195, 231, 263, $265,293,321,326,328$, $335,357,275$.

Chryfocoma 104, 136, 24.3, $266,294,358$.

Cicer 253.

Cinquefoil 166, 194, 197, $233,324,329$.

Cirfium 197, 266, 321.

Ciftus 74, 93, I0I, I04, I I9, I 3I, I 35, I36, I64, $166,171,173,198,201$, $207,233,240,241,265$, $272,295,321,329,332$. Citron 102, $174,194,20 \%$, 240.

Cives 39, 8I, I14, I47.

Clary $84,177,181,195$, $234,253,358,376$.

Claytonia 165 .

Clematis $27,95,167,233$, 354,372 .

Clethra 198, 233, 267, 295 . 329.

Cliffortia 300, 332.

Clinopodium 265,354 .

Clitoria 266, $273,300$.

Cliver 167.

Clove-gilliflower 232, 234 .

Clover 82.

Clutia 73, I36, 174,208 , $242,300,331,336,358$.

Coccygria 198, 324 .

Cockfcomb 25, 328 .

Coffee $33,71,74,104,135$, I 72, I 74, 207, 24I, 27I, 357,375 .

Colchicum 95, 127, I29, $158,264,290,293,328$, 353 .

Coleworts $13,50,83$, Ir 3 , 147 , 


\section{I $\mathrm{N} \quad \mathrm{D} \quad \mathrm{E} \quad \mathrm{X}$.}

T47, $210,247,276,277$, $301,305,309,313,343$, 346.

Collinfonia 266.

Coltsfoot 63, 96, 13 r.

Columbine 58, 88, 92, I29, $160,164,167,194,196$, $225,292,32 \mathrm{I}$.

Colutea 136, 166, 197, 198, $207,241,272,299,35$ I, 354.

Comfrey I67, I99, 234.

Commelina $265,273,300$, 329.

Compoft 24, I $3^{3}$, I 7 I, 204, 352,375 .

Convolvulus 9I, 92, 12.3, I24, I 36, I 59, I73, I9I, $208,232,261,264,266$, $272,273,294,300,328$.

Conyza 201, 232, $273,336$. Coral-tree 74, 105, 136, I73, 208, 24I, 334.

Coriander 13, 50, 148, 267, 343.

Coriaria 62.

Cork tree 9.3.

Cornelian Cherry 267, 324.

Cornflag 164, 196, 203.

Cornifh Cherry 130.

Cornfallet $38,183,212,247$, $309,343$.

Cornutia 273.

Corona Regalis $7 千$.

Coronilla 104, I30, I35, $167,195,232,265$.

Cortus 242,$2 ; 2,300,336$.

Cotton-plant 207, 241, 272.

Cotyledon 32, 72, 73, 104 , $136,169,174,202,207$, $236,241,272,299,331$, $335,357,374$.

Cowllip 13 s.
Cranes-bill 167, 196, 199.

Craffula 35, $136,174,202$, $208,243,273,336,358$.

Crefs $3,13,45,50,80,81$, $148,179,212,216,234$, $25 \mathrm{I}, 277,295,309,340$, $343,360,365$.

Crinum $35,74,104,136$, $173,203,208,242,273$, $300,336,35^{8}$.

Crocus 6I, 95, I58, I6 $\mathrm{r}$, I 9 I, 262, 293, 320, 328.

Croffwort 167.

Crotolaria 208, 242, 273.

Crowfoot 165.

Crown Imperial 95, 1 29, 192 , 259, 2.90.

Cucumber $3,6,16,25,4 \mathrm{I}$, $42,75,80,84,106,110$, II4, I4I, I46, 147, I77, $180,183,210,214,216$, $248,253,281,295,308$, 342.

Cudweed 234.

Cunonia $105,136,173,203$.

Cyanella 273.

Cyanus 164, 196.

Cyclamen 23, 27, 35, 6r, $73,95,104,129,135$, 159,17 , $191,199,203$, $262,264,290,293,328$, $331,335,358,371,375$. Cyprefs $27,62,93,96,119$, I20, 156.

Cytifus 95, 104, I19, I30, $135,166,167,198,201$, $233,267,295,299,324$, 329,332 .

D.

Daffodil 95,:29, 197. 


\section{I $N \quad D \quad E \quad X$.}

Daboon Holly 233.

Daifey $58,88,95$, I 29, I 31 , $163,164,165,167,242$, 289, $32 \mathrm{r}$.

Dames Gilliflower 194.

Dandelion $77,131,138,167$, 182.

Datura 230.

Dayénia $243,273,300$.

Dead-nettle 131; 167 .

December 359 .

Dens Canis 95, 129, I9I, 225 .

Devil's. bit 198.

Dianthera 232, 266, 294, 329.

Diervilla $167,198,233,267$, 354.

Digitalis 292.

Dill $77,234,253,267$.

Diolma $35,136,174,208$, $242,273,299,33 \mathrm{I}, 336$, 358,375 .

Diofpyros 198.

Dittander 198,234 .

Dittany 196,232 .

Dock-root 28.

Dodartia 165, 232, 294.

Dodder 234.

Dogibane 195, 328 .

Dogwood 96, 99, 130, 167, 198,233 .

Doria 201, 243, 272, 299, 332, 357 .

Doronicum 197, 32 I.

Dracocephaluin 91, 232, 265, 329.

Drayon 28, 164, 196, 199, 24.2 .

Dropwort 28, 234.

Ducksfoot 129 .

Dumb Cane 136.
Dwarf Annual Stock 9r, I64, $196,228,230,263,265$.

Dyers-broom 267 .

Dyers-weed 167 .

\section{E.}

Echium 266, 294.

Elder 27, 96, 199, 234, 295.

Elecampane 28, 354, 372.

Elichryfum 136, 173, 20I, $265,272,331,375$.

$E \operatorname{lm} 63,318$.

Endive 4, 5, II, 13 , 45, 50, 77,84, II $3,139,179$, $183,210,212,214,215$, $216,246,248,253,267$, $277,281,302,309,340$, $343,36 \mathrm{r}, 365$.

Erhetia 273.

Eryngium 265, 32r.

Eryngo 28, 232, 330, 354. Efchalot 21 2, 248 .

Efpaliers I $3,17,51,52,116$, $148,183,216,218,221$. Evergreens 29, 59, 63, 64, $93,96,97, \quad 119, \quad 121$, I28, I $57,189,223,224$, 257.

Everlafting Pea 124, I95, $230,264,32 \mathrm{r}$.

Euonymus $167,329,354$.

Eupatorium 196, 231, 266,

$2.72,294,329,354$.

Euphorbium 34, 35, 72, 73, $105,136,169,174,202$, $208,236,358,27 \mathrm{I}, 273$, $299,334 ., 335,374$.

Exoticks 66, 67, 72, 94, 97, 100, 101, 102, 103, 119, I20, I32, I35, I6I, 169 , $171,189,190,201,2.03$, 236 , 


\section{I $N$ D $E$ X.}

$236,237,239,268,269$,

271,298 ; 33I, 332, 349, $355,356,368,370,37$ I, 374,375 .

Eyebright 199, 234.

\section{F.}

Fabago I7I, I74, 20I, 232, $24 I, 272$.

Fairchild's Mule 230, 265.

February 36.

Fennel 28, 77, 247, 253, $295,354,372$.

Fennel-giant I 96 .

Fenugreek 295.

Fern 28, 295, 36 I, 363, 369

Feverfew I65, 198, 231, 234, $265,289,321,328$.

Ficoides 25, 72, 73, 173, 328,375 .

Fiddlewood 334 .

Figs, or Fig-iree I 3, I4, 5 I II $8,253,256,284,299$, $315,344,345$.

Figwort 164, 196, I98.

Filbert $62,256,284$.

Finnochia 82 , I 13, I 43 , I78,

$179,216,252,309$.

Fir $62,94,96,119,120$,

I 22, I 56, 224, 286.

Flammula Jovis 195.

Flax 82, I 2 , Ig $9,234,295$.

Fleabane 104 .

Fleawort 267.

Flixweed, 295.

Flower-fence 35.

Flower-Garden work 83, I 57 , I $90,287,320,349$.

Fluellin 23t.

Foreft tree 2.9, 30, 59, 63, $12 \mathrm{I}, 223,257,285,318$. Foxglove 58, 136, 160, I65:
174, 194, 196, 199, 208, $225,321,354$.

Fraxinella 88, 164, I 96, 292, 350.

French Honeyfuckle 58, 88, 92, I 24, I 60, I 94, I95, 225,$321 ; 350$.

Friers Cowl 129.

Frittillary 129, I9I, I92, $225,259,262,290,322$. Fruit-Garden work I3, 5 I, $84,114,148,183,216$, 253, 281, 309, 344, 365. Fruits in Prime 20, 55, 8\%, I I $, 187,22$ I 255,283 , - $315,347,36 \%$.

Fruit-trees I5, I6, 29, 30, $48,49,51,52,53,84$; $85,86,97$, I I 5 , I I 6 , I I 7, I 2 I, I 52, I 53, 210 , $2.20,221,282,283,285$, $31 \mathrm{I}, 345,360,365,366$. Fumitory 95, 129, 138,167 ; I $96,232,266,321,37$ i.

\section{G。}

Galeopfis 329 .

Galingale 300.

Garlick I2, 39, 50, 212; $216,248,267,281,343$.

Gaura 92, 266.

Gelder Rofe 166, 324.

Genifta 198, 233, 267, 354; 372.

Geniftella $233^{\circ}$

Gentian 28, 164, 196, 294, $329,350$.

Gentianella 58, I29, 195 , $263,292,350$.

Geranium $34,67,73,88$, $104,335,164,171,173$, $201 z^{\circ}$ 


\section{I $\mathrm{N} \quad \mathrm{D} \quad \mathrm{E} \quad \mathrm{X}$.}

$201,208,236,241,265$, $272,292,300,321,330$, $335,357,375$.

Germander 197, I99, 234. Gefneria 208.

Ginger $3 \mathrm{co}, 336$.

Gimfeng 232.

Gladiolus 35, 74, I05, 331. Glaffwort 267.

Glaucium 265.

Globe Thiftle 197, 23r, 265. Globularia $165,266$.

Glycine 231, 233, 266.

Graphalium 207, 241, 266, 294, 299, 358.

Goats-rue 234.

Golden Rod 58, 88, I95, $231,264,267,292,293$, $295,32 \mathrm{I}, 328,350,353$, 371 .

Gomphrena 60, 124, 230, $231,264,294,328$.

Gooberry 14, 54, 65, 187 , $222,234,267,282,285$, $312,313,319,345$.

Gound 146, 253, 281 .

Grafting $15,53,65,35,98$, $120,133,155,220,257$, 268, 311 .

Granadilla 299.

Grape 21, 152, 187, 253, $256,282,284,3$ II, 3I 5 , 347,368 .

Grafs 60, I23, I63, 264, $32.5,353$.

Grafs-plat 226.

Grais Walks. 122, 163,226 , 325.

Gravel Walks 6c, I22, 163 , $264,325,353$.

Green-houle work 30, 66 ,
I00, I 31, I68, I99, 235, $268,295,330,355,373$. Grewia 208, 241, 273, 299. Gromwell 295.

Ground Ivy $131,167$.

Groundfel 35, 138, 167, 182 , $299,329,372$.

Guajava 358.

Guanabanus 273.

Guava 272 .

H.

Hremanthus $13^{6}, 158,174$, 203, 208, 241, 266, 272, $300,334,336$.

Halleria $20 x$.

Hamemelis $27,62,295,329$.

Hare-bell I 31 .

Harts-tongue 372 .

Haw 96, $167,317$.

Hawk-weed $266,328$.

Hawthorn I30, I65, I 97 , $317,324$.

Hazle-nuts $62,284,315$, 347.

Hearts-eafe 27, 62, 95, 129, $164,294,328,353$.

Hedges 2, 3, 28, 75,226 , $342,367,360$.

Hedyfarum $16_{5}, 208,242$, $265,272$.

Helenia 329, 354.

Helianthemum ig, 232,265 , 294.

Helictrope 136, 173, I74, $208,232,241,243,273$, 294, 2.99, 300, 323, 332, 358,375 .

Hellebore 26, 61, 95, 174, $195,230,371,372$. C. Hemlock 
I $\mathrm{N} D \mathrm{E}$ X.

Hemlock 38, 199.

Hemorocallis 129.

Hemp 82, if 2, 295.

Henbane 28, 234, 330, 354, 372.

Heparica 58, 6r, 88, 95, 129 . Herb Paris $167^{\circ}$

Herb Robert 139 .

Hermannia $35,73,104,135$, $871,173,201,208,236$, $273,331,358$.

Hermodactyl 95 .

Heiperis 294.

Hibilcus $35,52,6 \mathrm{I}, 9 \mathrm{I}, 124$,

I9I, 207, 24I, 266, 294, $300,334,335$.

Hieracium 81, 88, 92, 123, 195, 230.

Hips 317 .

Hollow-root 95.

Holly. 64, 93, 97, 99, 119 , $120,156,197,231,233$, 317.

Hollyhock 124, 160, 194, $225,231,264,293,320$. Honefty I65, 321, 350 . Honeyfuckle $58,59,62,88$, 95, I 30, 166, 197, 199, $233,234,266,26 \%, 285$, $294,3 ! 9,324,325,329$, $35 \mathrm{I}, 372$.

Honeywort 129, 164, 197, $232,329$.

Hops 49, II 2, II3, 295. Horehound 198, 234, 357. Horminum 232 .

Horfe-cheftnut $166,324,35 \mathrm{I}$. Horfe-radin 216, 253, 343, 364.

Horfetail 167 .

Hot-bed $3,10,13,18,25$, $4 \mathrm{I}, 42,43,44,45,48$,
50, 54, 60, 61, 66, 67

$68,69,73,75,76,80$,

$84,92,93,94,99,101$,

102, III, II 4, I24, I25, $161,162,169,170,190$, $202,203,205,236,237$, $239,275,305,307,340$, $341,342,343,360,362$, 365.

Hound's-tongue 199 .

Houfleek 74, 104, 136, 199, 299.

Humble plant $136,241,272$, 299,335 .

Hyacinth 2I, 22, 23, 27, 6I, $89,95,127,129,136$, $157,158,164,192,225$, $259,26 \mathrm{I}, 262,265,288$, $290,293,320,322,327$, 352,369 .

Hydrangea 233,267, 294,329, $35 \mathrm{x}$.

Hypericum 74, 130, 136, $171,197,232,266,351$. Hyflop $13,50,78,81,84$, $113,144,176,177,183$, $195,199,234,247,253$, $28 \mathrm{I}, 344,364$.

I.

Jacea $195,228$.

Jacobæa 104, 242.

January $\mathbf{I}$.

Jarmine $35,59,73,104$, $130,133,166,169,171$, I73, 194, 197, 207, 208, $226,232,234,239,24 \mathrm{r}$, $266,267,268,272,294$, $299,324,330,335,351$, $357,358,375$.

Iatropha 173, 207, 241, 272.

7 Indian 


\section{N.D E X.}

Indian Fig $173,202,272$, Kitchen Garcen products 12,

334.

Indian Pink 92, I24, 232.

Indian flowering Reed 35\%, 375 .

Indian Yellow 35 .

Indigo $272,299$.

Indigo (Baftard) 233.

Inula 231 .

Johnfonsa 242.

Juhnfwort 104, 197, 199,

$234,241,272,295,329$,

335 .

Jonquil I 29, 320, 327 .

Iris 23, 28, 6I, 95, 129, $162,164,191,195,225$, $232,242,259,262,265$, $290,292,320,321,350$, 354.

Itea I98, 233, 267, 295, 329. Jujube 173 .

July 209 .

June 175 .

Juniper $93,96,99,120,156$, 330.

Juftitia $105,334$.

Ivy $28,62$.

Ixia $35,74,105,135,173$, 203,331 .

\section{K.}

Kalmia 233, 267, 272, 295 . Kempferia I74, 242, 273 , 300.

Ketmia 25, I97, 265, 329.

Kidney-bean $43,44,81,84$, $10 \%$, I14, I 39,148 , I79, $183,209,215,252,267$, $28 \mathrm{I}$.

Kiggelaria $174,208$.

King's Spear 331, 33\%
$50,83, \quad 113,147,183$, $216,252,281,309,343$, 364.

Kitchen Garden work I, 36, $75,106,137,175,209$, $244,274,301,337,359$. Kleinia 202, 243, 300, 331, $33^{6}$.

Knotgra!s 199, 234, 257.

L.

Laburnum 59, I 30, I66, 324, $35 \mathrm{I}$.

Ladies bedfraw I99, 234 .

Ladies mantle 164,157 , 199.

I. adies Mipper I64.

Ladies fmock $129,165,167$.

L.amium 197.

Lantana 35, 73, 104, 135 , $201,207,208,241,273$, $299,335,336,357,375$. Larch-tree 96.

Larkfpur 61, 92, 195, 228,

231, 293.

Lathyrus 230, 292.

Lavatera 35, 91, I23, I74, $195,208,230,243,264$, 295.

Lavender 50, 78, 108, I44. 176, 18I, 183 , I9I, I96, $234,247,251,253,266$, $272,276,330$.

Lavender Cotton 78, Ic8, I99.

Lavender-fpike 199.

Lavendula 265.

Laurel I30, I56, I98, $233^{\circ}$. 284, 293, 319. I,aurus Regia 208. Lauruftinus 27, 62, 95, Ior, C 52 I28, 


\section{N D $\mathrm{E} \quad \mathrm{X}$.}

I 28, I 30, I 3I, 266, 293, 294, 319, 324, 329, 354, 372.

Lawn 60, $163,324$.

Layers 63, 66, I69, 189, 191, $225,228,239,25^{8}, 287$, 318.

Lazarole 96, 284.

Leadwort 242, 354.

Leeks 9, I 2, 45, 50, 77, 82, $108,114,143,146,176$, $182,250,281,309,341$, 364 .

Lemnn 35, I02, I 74, 194, $207,240$.

Lentil 295.

Lentifcus I 7 I, 208, 242, 33 I. Leontopetalon 129.

Leonurus $35,201,236,263$, $272,299,331,335,357$, 374,375 .

Leopardfbane 129,164 .

Lettuce 2, 1 2, 1 3, 36, 37, $44,45,50,78,79$, I09, III, II4, I43, I47, I79, $183,215,216,246,247$, $252,275,278,281,295$, $302,309,339,340,343$, $3^{6} 3,365$.

Leucanthemum 88.

Lilac 59, 130, 166, 318, 324, 325,351 .

Lily 74, I29, I 36, 162, 164, 167 , 192, 195, 196, 198, $204,225,230,234,242$, $259,260,262,292,299$, $320,328,335,358$.

Lime 63, 174, 197, 199, $20 \%, 240,318$.

Limodorum 273, 300, 336.

Limonium 231, 265, 272.

Liriaria $123,195,230,265$, 266; 328.
Lionftail 74 .

Liquorice 28, 4I.

Liverwort 62, 96 .

London Pride $164,289,321$, 350.

Loofeftrife $195,198$.

Lotus $35,105,123,136$, 166, $173,174,201,208$, $299,300,331,334,336$, 376 .

Loveage 234, 247, 295, 330, 372.

Love Apple 92, 191, 267.

Love-lies-a-bleeding 92.

Lucern 82 .

Lungwort 95, $129,165,167$. Loupine 123, 159, 196, 228, $231,265,266,267,293$, 328.

Lychnidea 160, I65, 266.

Lychnis 58, 88, 91, 92, 123, 129, 159, 160, 194, 195, $196,225,227,231,263$, $265,289,292,294,328$, 350 .

Lycium 104, 136, 174, 208, $242,331,376$.

Lyfimachia $232,265,321$.

\section{M.}

Madder $2 S$.

Magnolia 93, I20, 198, 233, 266,332 .

Maidenhair 27, 62 . Malabar Nut 331.

Mallow 35, 123, 166, 197 , I98, 199, 207, 231, 233, $234,264,266,294,358$, 375 .

Malpighia $35,73,105,136$, $173,208,273,300,334$, $336,358,375$.

Mandrake 


\section{$\begin{array}{lllll}I & N & D & E & X\end{array}$}

Mandrake 28, $165,16 \%$.

Manna AR, ree Afh.

Maple $95,96,130,167,28 \%$, $318,324$.

Maranta 207, 242, 336. March 75.

Marigold 35, 38, 77, 84, 92, $104,105,124,136,159$, $174,177,181,191,105$, I99, 20I, 216, 23I, 232, $234,241,242,253,265$, $293,309,328,336,344$. Marjoram 50, 81, 107, II3, I7, 216, 253,267, 28I, $309,344$.

Martagon 164, Ig6, 225, $230,259,262,320$. Martynia I9I, 208, 230, 242, $272,300,336$.

Marvel of Peru 92, 124, 159 , I9I, $231,264,293,328$. Marum I44, 183. Malterwort 27, $234,247$. Maftich 108, 144, 183,234 , 251.

Maudlin 164, I99.

Maurocenia 242, 300.

May 137.

Meadia 129, I65, 263.

Meadowfweet 292.

Medicago 104, I I9, I35, $197,267,295,354,372$. Medicinal Plants 27, 62, 96 , $130,167,198,233,267$, $295,330,354,372$. Medlar 21, 96, 166, 284 , $295,315,347,368$. Melianthus 131; 136, 173, $198,207,236$.

Melilot 198, 234.

Melocactus 174, $35^{8}$.

Melon 6, 16, 41, 43, 75, 80,
I06, I07, I I 0, I 4 I, I 42, $148,177,178,18$; 183 , $213,216,249,253,28 \mathrm{I}$, $284,308$.

Melongena 25, 265.

Melon Thiftle 34, 72, 208, $242,273$.

Mercury 167.

Mefembrianthemum 32, 35 , $60,104,135,169,202$, $207,230,241,268,272$, $299,330,335,358,375$. Mépilus 354.

Mezereon 27, 62, 95, 234, $324,372$.

Milfoil 234.

Milleria 273, 300, 336.

Millet 295.

Mimofa 207.

Mimulus 232.

Mint Io, I3, 50, 78,84 , I I I, $147,181,183,216$, $253,307,308,365$.

Moldavica 123.

Molle 33 I.

Molucca 265.

Moly 164 .

Momordica 6I, 242.

Monarda 232, 266, 294, $32 \mathrm{I}$. Monkfhood I64, $321,350$.

Moon Trefoil 93, 166.

Morea 105.

Mors I 5, 53, 57, 62, 65, 9I, $97,204,330$.

Motherwort 234.

Moth-Mullein 129, 164, 196, I 98, 23I, 234.

Moufe-ear I31, 167 .

Mugwort 199.

Mulch 97, I17, I19, 128, $157,169,183,189,2$ I , $286,312,317,324,345$, C 3 $3+8$, 


\section{I D E X.}

Mulcari 95, 129 .

Noli me tangere 164.

November 337 .

Mufhroom 5, 13, 43, 50, Nurfery work 28, 63, 96, $148,253,275,281,307, \quad 119,154,187,222,257$, $308,309,343,364$.

Munk Rore 266, 294, 329,

354.

Muttard 3, I3, 45, 50, 81, $109,148,179,183,199$, $210,234,25 \mathrm{I}, 277,295$, $300,340,343,360,365$. Miyofotis 263.

Myrica 233.

Myifine 173.

$284,355,348,368$.

Nuts 21, 96, 368 .

Myrtle 35, 67, 100, 101, I19, I31, 166, 169, 173, $200,207,233,236,240$, $272,297,299,332,335$, 357,374 .

Myrtus 334.

\section{N.}

Napellus 265 .

Narciffus $22,27,6 \mathrm{I}, 95$, $129,162,164,192,225$, $262,320,327,354,371$. Nafturtium $34,91,123,159$, $207,23 \mathrm{I}, 24 \mathrm{I}, 253,2.65$, $2.72,294,299,330,357$, 375 .

Navelwort $61,95,165,167$, $32 \%$.

Navew-root $26 \%$.

Neclarine 84, $149,150,184$, $187,188,222,256,309$, 344.

Nettle 96, 130, 165, 197, 267 .

Nigella 92, 195, 23r, 264. Nightihade I82, 250, 26\%, 295 .

0.

Oaks 93, 96, IIg.

Octoner 30 I.

Oculus Chrifti 234.

Oldenlandia 300.

Oleander I $3 \mathrm{I}, \mathrm{I} 7 \mathrm{I}, 208,24 \mathrm{I}$, $272,299,332,336,374$.

Oleafter 197,233 .

Olive 131, $136,207,242$, 332.

Omphalodes 165.

Onagra 265.

Onion 12, 39, 41, 50, 77, $108, I_{4}, 143,146,147$, $176,210,212,216,244$, $248,253,267,276,28$ r, $303,304,309,341,343$, 364 .

Onobrychis 165 .

Opuntia 336.

Orach 77,182 , 199.

Orange $30,35,67,68,69$, $70,100,101,102,131$, 132, 133, 168, 174, 194, $199,207,235,240,268$, $271,272,297,198,330$. Orchard woik 365. Orchis 28, 129, 164 . Origanum $183,234,28 \mathrm{r}$. Ornithogalum $104,129,135$, $165,196,203,224,230$, 300.

Orobus I64, 228, 266. Orgine 199,234 . 


\section{I $\mathrm{N} \quad \mathrm{D} E \mathrm{E}$ X.}

Ofteofpermum 35, 332.

Othonna 1.05, 136, 173, 201, $24 \mathrm{I}$.

Ox-eye 196, 234, 354 .

\section{P.}

\section{Pæonia 259.}

Palm tree 208.

Palma Chrifti 19 I, 265, 299. Pancratium 35, 74, 104, 136 , $158,173,208,242,273$, 300,336 .

Papaw 208, 299, 357 .

Papaya $35,174,24 \mathrm{I}, 273$, 335 .

Parfley 12, 13, 28, 36, 38, $50,77,79,84$, III 1113 , I $48,183,216,253,28 \mathrm{I}$, 295, 309, 34I, 343, 344, 364,365 .

Parfnep 9, 12, 36, 45, 50, $77,83,108,114,143,146$, $\mathbf{I} 6,250,253,28 \mathrm{I}, 309$, $34 \mathrm{I}, 343,364$.

Parthonia 232.

Pafferina $174,208,243,273$. Paffiflora, or Paffion-flower $169,174,188,197,207$, $233,239,241,266,272$, $294,329,335,354,358$. Pavia 233.

Pea (Cape Horn) 253 .

Peach (double Alowering) 324. Peaches $84,148,149,150$, $183,184,187,188,222$, $255,315,366$.

Peach-tree $130,309,344$. Pears 14, 20, 52, 55, 65, $118,154,187,221,222$, $253,282,284,310,314$, $315,346,347,367$.
Pear-tree 130,344 .

Peas 2, 4, 12, 36, 57, 40, $4 \mathrm{I}, 48,76,83,84,108$, $110,112,114,123,137$, $139,147,159,183,213$, $216,252,255,279,281$, $293,303,339,362$.

Pellitory 198.

Penny-royal 78, 183, 198, 234.

Peppermint I98, 234.

Periclymenum 267.

Periploca 198, 233, 265, 266. Periwinkle $2 \%, 62,129,164$, 196, 242.

Perficaria $162,265,294,328$. Perfimon or Pilhamin 96, 167, 233.

Peterfwort 27, r96, 321.

Phalangium 242, 265. Phlomis 1 $31,166,171,173$, $197,198,207,233,236$, $267,329$.

Phlox I94, I95, 23I, 32 I, 329.

Phylica 34, 73, 104, I7 I, $300,331,336,357,375$. Phyllanthus 2.08, 242.

Phyliyrea 27, 62, 93, 94, I $19,128,156,241,319$, 334.

Phyfalis 242, 265, 300, 328, 331, fee Alkekengi.

Phyfic-nut 299.

Phytolacca 208, 242, 243 ,

$2.72,300,334,336,35^{8}$. Piercea 174, 208, 242, 272 , $300,336,375$.

Pilewort 27, 95, 129, 321 . Pimpernel I38, 167, 182, 199.

Pine 28, 62, 94, 96, II 9, $\mathrm{C} \mathrm{C}_{4}$

$12 \mathrm{O}_{2}$ 


\section{N D E X.}

120, I22, 156, 190, 224, Pompion 146. $286,296$.

Pinks 58, 88, 92, 124, 125 , I 59, $160,161,162,163$, I65, 19I, 194, 195, 2.25, $227,230,258,259,264$, $287,289,294,328,354$.

Piony $28,164,167,292$, $321,350$.

Piper 200, 358 .

Piftachia-nut 96, I66, I98.

Plane $96,167,319$.

Plantain 163 , I99.

Plants in flower 26, 34, 6I,

$73,95,104,129,135$, $163,173,195,207,230$, $240,264,272,293,299$, $328,335,353,357,37$ I, 375 .

Pleafure Garden work 21, 56, I 22, I 90, $224,258,36 \mathrm{~g}$. Plumbago 273, 336, 354, 375 .

Plumeria 208, 242, 272, 300, 335.

Plums $53,62,65,184,222$, $256,283,310,315,317$.

Poinciana $35^{8}$.

Poley-mountain 196, 23 I.

Polium 266, 272, 294.

Polyanthes 273, 336 .

Polyanthus 26, 27, 56, 6I, $95,125,129,225,260$, $262,289,290,293,321$, $328,37 \mathrm{I}$.

Polygala 73, 104, I36, I 7 I, $173,20 \%, 241,273,335$, 375.

Polypody 372 .

Pomegranate I68, I69, I94, I97, 207, 233, 267, 294, 329.

Pomum Amoris, or Tomata 92.

Poplar 96, 167, 3 I9.

Poppy 9r, 164, 195, 196, $198,23 \mathrm{I}, 267,292,32 \mathrm{I}$. Potatoe 12, 46, 50, 83, 216 , 253, 28I, 309, 34 I, 343, 364.

Primrofe $27,92,95,131$, $195,225,232,260,289$, 293, 32 r, $37 \mathrm{r}$.

Prinos 267.

Privet I67, I98, 233, 324 .

Protea 334 .

Pforalea $174,207$.

Ptarmica I95, 23 r, 265, 293,

$358,376$.

Ptelia 197.

Pulfatilla I 29, I64, 262.

Pumkin $213,253$.

Puiflane $48,80,82,84,108$, $114,139,148,183,216$, $235,253$.

Pyracantha 27, II9, I 30 , I66, 329, 354 .

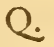

Quamoclit 242, 26I, 2\%2.

Quick-beam I 66, 324.

Quince $284,315$.

R.

Radilh 2, I3, 36, 37, 45, 50, 76, 80, 81, 108, 109, $2 I_{3}, I_{40}, I_{47}, I_{79}, I_{3}$, $214,216,251,253,277$, $281,295,307,309,340$, $343,360,363,365$.

Ragged Robin 58, 88, 165 , 5 I 96 , 


\section{N D E X.}

Ig6, 230, 263, 289, 32 I. Ragwort 74, $165,196,197$, 272, 354.

Rampion I3.

Ranunculus 21, 23, 58, 89, $127,129,157,163,165$, $192,261,262,289,290$, $291,320,321,352,369$. Rape 3, I 3, 45, 50, 81, 109, I 79, 183, 216, 251, $309,340,360,365$.

Ralpberry I5, I 7, 54, 86,

197, 199, 222, 235, 282, $312,313,324,329,346$. Rafpberry (flowering) 233 . Rauvolfia 1 36, I 74, 208, 242, $300,336$.

Reeds I73, 207, 308, 33I, $334,342$.

Refeda I 59, I9I, I97, 242, 328.

Reftharrow 166,167 , 199, 232, 234 .

Rhamnus 242.

Rhapontic 164 .

Rhododendron $267,35 \mathrm{r}$.

Rhubarb 28.

Rhus I7r.

Ricinus 6r, 23I, 242, 273.

Robinia $167,273,324$.

Rocambole 12, 39, 50, 82,

I I $4,212,216,248,309$,

343,364 .

Rocket $164,234,263,350$. Rondeletia 300.

Ros Solis I98, 234.

Role 59, I 30, 166, I94, I97, I.99, 226, 232, 233, 294, $317,318,324,325,329$, 354.

Rofe Campion 58, 88, 91, 92,
I95, 225, 23I, 263, 289, $32 \mathrm{I}, 350$.

Rofemary $13,50,78,84,108$, I $4,144,164,166,167$, $176,183,199,247,251$, $253,276,309,364$.

Rofe-root 95, I 29.

Royenia I73, 243, 273, 332. Rudbeckia 232, 266, 294 , $321,328,375$.

Rue ro8, 234.

Ruellia 242, 300.

Rupturewort 199.

Ruyfchiana 196, 232, 266, 294, 32 I.

Rye 82.

S.

Safflower 267.

Saffron $123,127,158,19 r$. $293,295,309,328,330$. Sage $30,50,78,84,108,114$. I36, I 44, I 64, I 73, г 76 . I8r, I83, I98, 20r, 207 , $216,234,236,242,25 \mathrm{I}$, $253,273,343,358,364$ 。 Saintfoin 82.

Sallet herbs 3, 4, I 3, 37, 45, 50, $76,81,84$, I09, I I3, 139, 179, $183,215,251$, $253,277,28 r, 305,309$, $340,360,365$.

Salfafy $13,37,50,114,145$, 2I6, 28I, 309, 34 I, 342, $343,364$.

Salvia 336.

Sanguinaria 129.

Sanicle I98.

Santolina 195, 232, 294

Saffafras 96, 99, 233.

Savin 295, 330, 354, 372. 


\section{I $N$ D E X.}

Savory i3, 38, 50, 84, 107 , I08, I: 3 , I3I, 147 , I 6 , $783,247,253,267,28 I$, $309,344,364$.

Savoy 9, I2, 44, 45, 50, $76,78,83$, III, II2, I I $3,140,146,175,210$, $234,249,309,343,362$, 364 .

Saxifrage $28,62,95$, I29, I $3 \mathrm{I}, \mathrm{16} 5$, I98.

Scabious 92, I05, I35, I62, I65, I7I, I73, I94, I96, $198,207,225,23 I, 24 I$, $263,264,293,299,328$, 354.

Scallion 39, 8I, I 14.

Sclarea $232,265$.

Scordium 234.

Scorpion Sena I98, 266, 294, $324,329$.

Scorzonera I 3, 37, 50, I45, $216,253,266,28 \mathrm{I}, 309$, $330,341,343,354,364$, 372.

Scrophularia 92, 231, 294, 329.

Scurvy-grafs I67, 247.

Sea-Cabbage 165.

Securidaca I23.

Sedum 32, 35, 72, 95, 169, $202,207,268,272,331$, $357,373,376$.

Self-heal 198.

Sena 59, 73, 1 30, 166, 272, $300,328,336$.

Senecio 73, I04, 236, 266, $272,336,357,375$.

Sentitive plant $272,299,335$, $35^{8}, 375$.

September 274.

Service 2r, I30, 166, 315, $347,368$.
Seffeli $247,20,5$.

Shaddock 207, 240.

Shallot I $2,39,50,82,28$ I, $309,343,364$.

Shepherds-pouch I 38.

Shepherds-purfe 13 I, 167 , I82, Igo.

Sherardia 266, 336 .

Sida 23 I, 273.

Silphium 232, 294.

Silverweed 167 , I99.

Sifyrinchium 74, 105,136 , I73, 203, 33:.

Skirret $13,28,37,50,78$, I 45, 309, 330, 343, 354, 364,372 .

Sinallage $27,77$.

Smilax 196.

Snail-plant 92, I23, I 59.

Snapdragon $195,293,328$.

Sneezwort 234, 293.

Snowdrop 27, 61, 95, I29, I6I, I9I, I98, 37 r.

Solanum I 74, 208, 242, 265, 272, 294, 299, 331, 334, 335,376 .

Soldanella 62.

Solidago 34 .

Solomon's Seal 28, I 29, I64, 292, 372.

Sopewort 232, 265, 293 , $329,330,372$.

Scrrel I3, 35, 38, 50, 74, 77,105, I I $3,131,136$, $147,167,171,177,18_{3}$, $208,216,236,242,253$, $273,281,300,309,331$, $344,358,365,376$. Southernwood 78 . Sowthiftle 182, 199. Spartium 233, 267, 299. Spearmint I98, 234.

Speed- 


\section{I $N$ D E $\mathrm{X}$.}

Speedwell $88,165,198,234$, 245.

Spiderwort $164,196,231$, $265,293,321,329$.

Spigelia 242, 266, 273, 300, 336.

Spignel 28, 372.

Spinach 12, 13, 36, 37, 50, $76,77,80,83$, I I 3,140 , 147, 199, 210, 212, 216 , $244,252,253,276,303$, $309,34 \mathrm{I}, 343$.

Spindle-tree I I9, I 30, I98. Spiræa 130, I66, I97, I98, $233,267,324,325,329$, $35 \mathrm{I}$.

Spleenwort 27.

Sprouts I3, 50, 83, II 3,

$253,28 \mathrm{r}, 309,343$.

Spurge I65, 299.

Spurge-laurel 27, 62, 95,

372.

Squafhes $28 \mathrm{r}$.

Squills $197,203$.

Stapelea 24. $272,299$.

Star Flower 95.

Starwort 58, 6I, 74, I05, $125,136,159,160,174$, I9I, 20I, 23I, 242, 264 , $265,267,273,294,328$, $350,353,357,358$.

Statice 23 r.

Stock-gilliflowers 92, I24, I6I, I64, I94, 22.5, 23I, $293,328,353,37$ I.

Stocks 28, 30, 53, 65, 86, 98, I O2, I I 2 , I I 5, I I6, I 20, I 2 I, I 55, I 59, I 88 , $223,255,257,268,285$, 286, 3II, 3I2, 3I4, 3I6, $317,35 \mathrm{I}$.

Stoechas 108, I 36, I67, I 76, I $83,199,234,251,265$,
$267,276,350$.

Stonecrop i67, 198.

Siove, work to be done $3 \mathrm{C}_{2}$ 66, I00, I 31, I68, I99, $235,268,295,330,335$, 355,373 .

Stramonium 25, 60, 92, I9I, $242,26 I, 265,294,299$. Strawberry I7, I8, 27,54 , 86, 94, II7, II9, I87, Ig9, 222, 282, 3I 2, 3I3, $329,346,354,372$.

Succory I99, 234.

Suckers $145,270,282,318$,

$319,325,326$.

Sultan 9I, 92, I 24, I 59, I62, I9I, I95, 228, 2.3I, $263,264,293,328$.

Sumach I $36,166,197,201$, $208,233,267,295,324$, 329.

Sunflower 88, 9I, I96, 23r, $264,294,321,328,354$,

375 .

Swallowwort 27, 195, 232, 354.

Sweetbriar I98.

Sweet Cicily 234.

Sweet-fcented Pea 9r, 228, $230,263,264,328$.

Sweet-William 58, 88, 92, I 24, I60, I9I, I94, I95, $225,228,230,258,259$, 287,321 .

Symphoricarpos 295.

Syringa I97, 324, 35 I.

$$
\mathrm{T} \text {. }
$$

Tabernemontana 208.

Tamarind-tree 242.

Tamarifk I97, 233, 267, $295,324,329$. 


\section{I $\mathrm{N} \quad \mathrm{D} \quad \mathrm{E} \quad \mathrm{X}$.}

Tangie Pea 9I, 230, 264. Tanfey I0, 50, 74, 78, 84, $105,136,183,198,234$, $307,332$.

Tarconanthus 35.

Tarragon $13,50,78,84$,

I I I, I 48, I 99, 308,365 . Teafle 167 .

Tcrnatea 243.

Tetragonia 105, I36, 332, $35^{8}$.

Tetragonocarpos 242 .

Tetragonotheca 294.

Teucrium 104, I 31, I 36, I $73,208,358,375$.

Thalictrum 164,321 .

Thorn Apple I 59, I 82, 208, $267,328$.

Thorn (Chrif's) I 66.

Thorn (Glaftonbury) 27, 62 , I $30,324,372$.

Thorn (White) 166.

Thrift 58, 88, I64, I96, $28 \mathrm{~g}, 32 \mathrm{I}$.

Thyme I3, 78, 81, 107, 108, II 3, I77, I 83, I 99, $2 I 6,234,235,253,28 I$, $309,344,364$.

Thymelea 267.

Tithymalus 104, 208, 334 . Toad-Alax 136, $165,234$.

'Tobacco I9I, 232, 240, $242,265,267,329$.

Tomatoe 80, 147, 2 I6, 253 , $28 \mathrm{I}$.

Torch Thifte 72, 300, 334, fee $\mathrm{C}$ reus.

Tormentil 28, 234, 354.

Tournefortia 208, 273, 300. Toxicodendron 166, r98, $267,273$.

Trachelium $197,2.32,266$, $2.72,329$.
Tradefcantia 273.

Tragacantha 164 .

Tragopagon II4, I47, 266.

Travellers Joy 62, 95, 266.

Trees and Shrubs in flower $27,62,95,130,166$, I 97, 232, 266, 294, 329, 354,372 .

Trefoil I $98,232$.

Trumpet-flower 233 .

Tuberofe 6I, 125, 162, 205, $265,299,328$.

Tulip $23,27,58,61,89$, $95,127,129,157,162$, $163,192,193,261,262$, $288,289,290,29 \mathrm{I}, 320$, 322,327 .

Tulip-trie 96, I19, 120, $161,198,238$.

Tupelo Irg.

Turnep 3, I2, I3, 45, 50, 82,83 , IO9, III, II 3 , I45, I 48, I $78,179,183$, $210,216,251,252,253$, $276,277,281,309,340$, $343,360,364,365$.

Turnera $73,104,136,173$, 208, 242, 272, 290, 334, $336,35^{8}$.

Turpentine-tree $₫ 30$.

$$
\text { V. }
$$

Valerian 28, 92, 164, I96, 23r, 294, 330.

Valerian, the Greek 92, 160, $165,196,225$.

Valerianella 195 .

Venetian Vetch 95, I 29, 295. Venus Looking-glars $9 \mathrm{I}$, I23, I 59, 195, 231, 264, $293,328$.

Venus 


\section{$\begin{array}{lllll}\text { I } & \mathrm{N} & \mathrm{D} & \mathrm{E} & \mathrm{X} \text {. }\end{array}$}

Venus Navelwort 91, I23, I 59, I95, 228, 231, 263, $264,293,328$.

Verbafcum 129, 165.

Veronica 92, 164, I65, 195, $232,265,350$.

Vervain-mallow 199, 234, 267.

Viburnum I30, 167 , I97, $334,35 \mathrm{I}$.

Vinca 208.

Vines I4, I 5, 98, I 16, I I7, I4I, I42, I 50, I 53, I77, $186,187,219,220,254$, 309,3 II, 344, 366.

Vineyard I 86, 2 I 9 .

Vineyard work 216, 253.

Violet $62,63,95,96,129$, I64, 32 I, 328 .

Virgins-bower 156,188 ,

I95, I 98, 230, 266, 324 . Volkhameria 273, 300, 334 , 336.

Vulneraria I65, 197.

\section{W.}

Wackendorfia 24 I, 273, 332 . Wallflower 6I, 92, 95, I 24, I6I, I64, I94, I95, 225, $32.1,350$.

Wainut $96,284,287,295$, 3 I $5,347,368$.

Waltheria 136, I74, 208, $242,273$.

Water-crefs 63,96, I 3 , I6\%.
Water-dock 234.

Watfonia 74, 105, I36, 173 , 203, 33I.

Wheat 82 .

Whitlow-grafs 62, 96, I 31 . Wildernefs work 21, 60, 224.

Willow 230.

Willowweed I95.

Winter Cherry 330.

Woad I67.

Wolfsbane 88, I96, 294, $295,329,330$.

Woodroof I3I, 167 .

Wood Sorrel 167.

Wormwood 78, IOI, I3I, 174, 198, 199, 208, 233, $242,273,332$.

Woundwort 234 .

X.

Xeranthemum I95, 22.28,3I, $263,265,294$.

Y.

Yarrow 198.

Yew 93, 99, I I9.

Yewberry $31 \%$.

Yucca 242, 335.

Z.

Zinnia 6o, 159, I9I, 266 , 300.

Zygophyllum $33^{6}, 37^{6}$. 


\section{Lately Publifbed,}

(Neatly printed in one Volume Quarto, Price I1.5s.)

\section{$T H E$}

\section{A BRI D GEMEN T}

O F T H E

Gardeners Dictionary: C O N T A I I I G,

The beft and neweft IVthods of cultivating and improving the Kitchen, Fruit, Flower Garden, and Nurfery; as alfo for perform- ing the practical Parts of Hufbandry:

TOGETYIR TVITH

The Management of Vineyards, and the Method of making Wine in England.

In which likewife are included,

Directions for propagating and improving, from real Practice and Experience, Pafture Lands, and all Sorts of Timber Trees.

\section{By PIILIP MILLER, F.R.S.}

Gardener to the Worinipful Company of Apothecaries, at their Botanick Garden at Chelfea, and Member of the Bo. tanick Academy at Florence.

... Digna manet dieini gloria ruris. VIRG. G. I.v. 168.

The FIFTH EDITION. Corrected and Enlarged.

Printed for John Rivington in St. Paul's Cijurch-Yard, H. Woodfall, A. Millar, J. Whiston and B. White, G. HawkIns, J. Hinton, R. Baldwin, L. Hawes and W. Clarke and R. Collins, W. Johinstor, T. LongMan, 'T. Caslon, B. Law, C. Rivington, Z. Stuart, J. DODSLEY, and M. RICHARDSON. 

, 



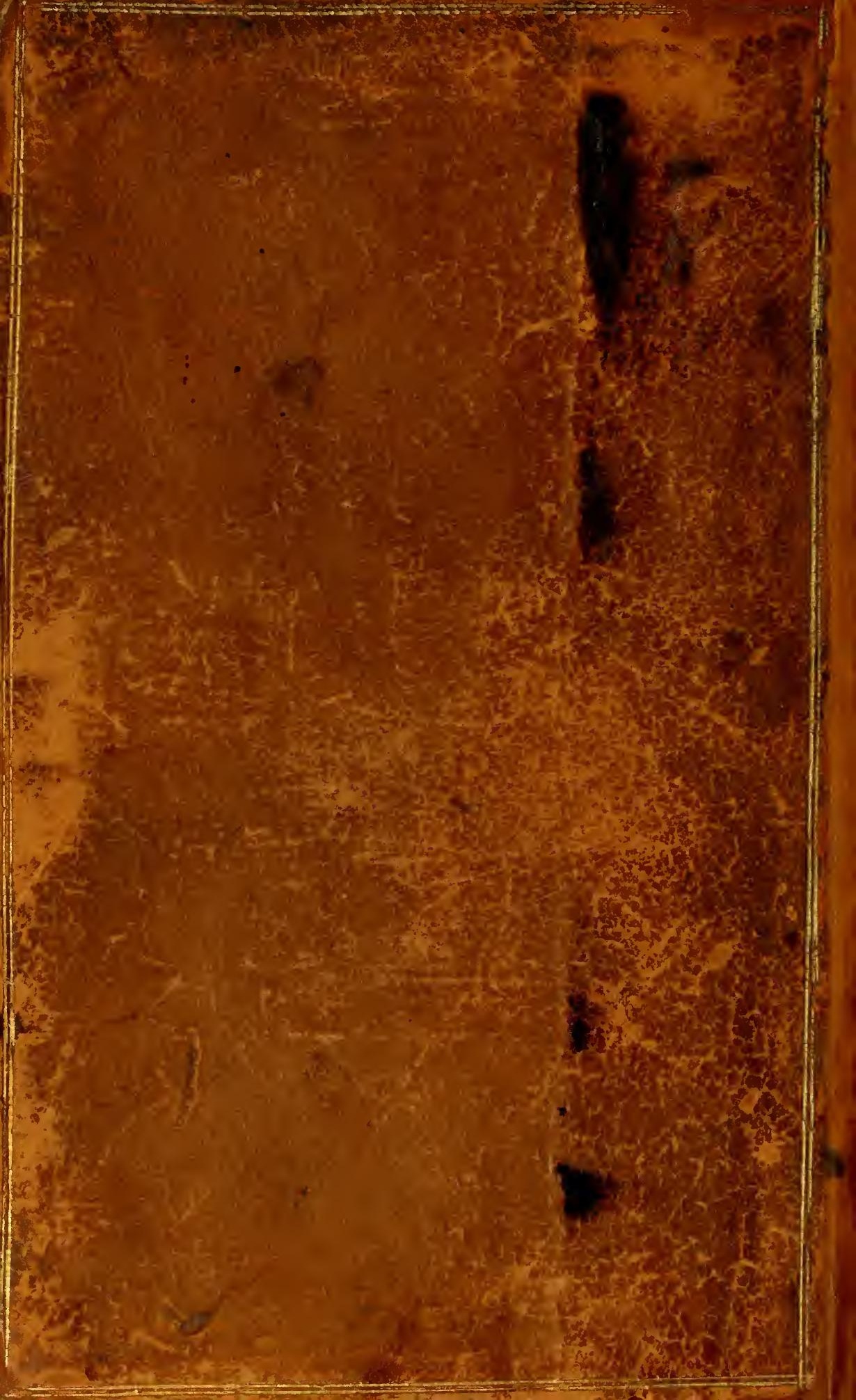

